
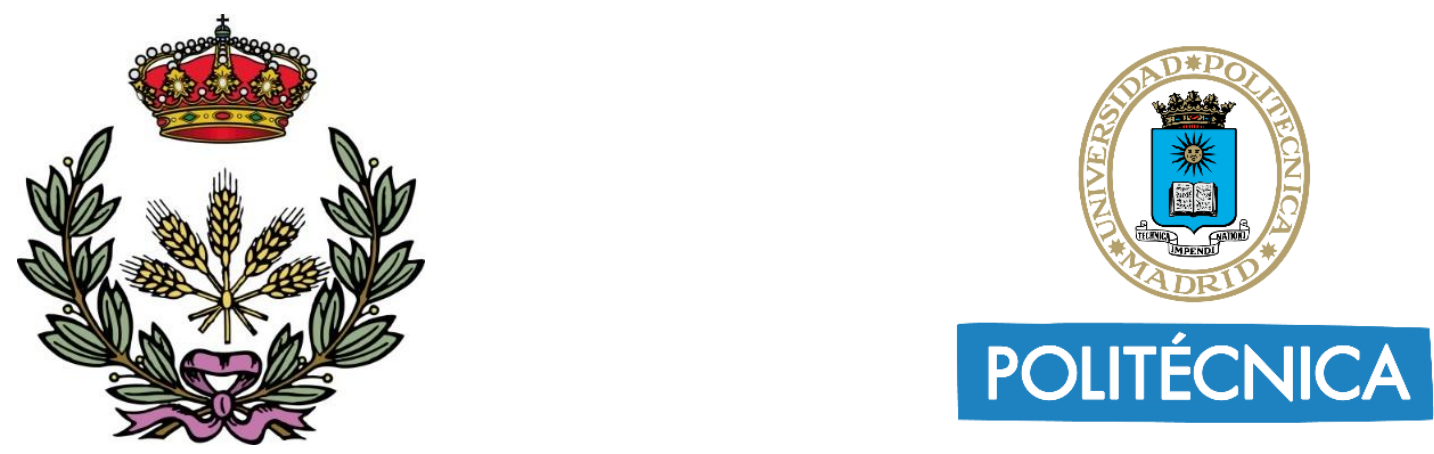

UNIVERSIDAD POLITÉCNICA DE MADRID

ESCUELA TÉNICA SUPERIOR DE INGENIERIA AGRONÓMICA, ALIMENTARIA Y DE BIOSISTEMAS

\title{
EFFECT OF NO-TILLAGE AND LIMING PRACTICES ON SOIL MICROBIAL PARAMETERS IN DEGRADED ACID SOILS OF SW SPAIN
}

Tesis doctoral

EDUARDO VÁZQUEZ GARCIA

INGENIERO AGRÓNOMO 

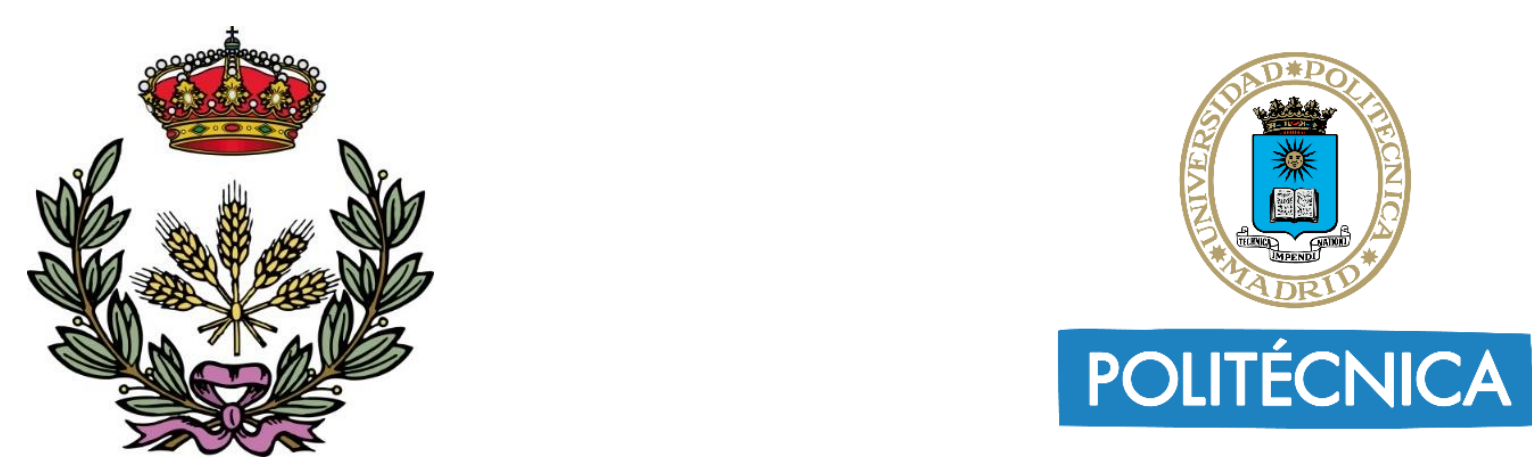

UNIVERSIDAD POLITÉCNICA DE MADRID

ESCUELA TÉNICA SUPERIOR DE INGENIERIA AGRONÓMICA, ALIMENTARIA Y DE BIOSISTEMAS

\section{EFFECT OF NO-TILLAGE AND LIMING PRACTICES \\ ON SOIL MICROBIAL PARAMETERS IN DEGRADED ACID SOILS OF SW SPAIN}

Memoria presentada por:

EDUARDO VÁZQUEZ GARCIA

INGENIERO AGRÓNOMO

Para la obtención del grado de doctor por la Universidad Politécnica de Madrid

Directores:

Rafael Espejo Serrano

Marta Benito Capa

Doctor Ingeniero Agrónomo

Doctora Ingeniera Agrónoma

MADRID 2019 
Tribunal nombrado por el Magfco. Y Excmo. Sr. Rector de la Universidad Politécnica de Madrid, el día de de 2019

Presidente:

Vocal:

Vocal:

Vocal:

Secreatario:

Suplente:

Suplente:

Realizato el acto de defensa y lectura de la tesis el día en la E.T.S.

Ingeniería Agronómica, Alimentaria y de Biosistemas de la Universidad Politécnica de Madrid.

Calificación:

EL PRESIDENTE

EL SECRETARIO 


\section{ACKNOWLEDGEMENTS}

En primer lugar, quisiera agradecer al Ministerio de Educación por la concesión de una beca FPU que me ha permitido desarrollar esta tesis doctoral. Y por extensión, quisiera agradecer al sistema educativo español por toda la formación recibida durante los últimos 25 años. Ojalá en el futuro más y más estudiantes puedan seguir disfrutando de esta oportunidad que yo he tenido y a poder ser, con becas y medios más cuantiosos. Como canta Silvio Rodríguez "Yo vivo de preguntar, saber no puede lujo"

En segundo lugar, quiero agradecer a Marta Benito y Rafael Espejo la oportunidad de llevar a cabo el doctorado bajo su dirección. Gracias por darme la libertad y la confianza como para acertar y equivocarme por mis propias decisiones, lo que creo que me ha hecho crecer más que si sólo hubiese tenido que seguir una vereda doctoral como un burro. Gracias también por darme la confianza como para ir de allá para acá en busca de ensayos y nuevos análisis por hacer. Gracias Marta por solucionarme tantístimas peplas a miles de kilómetros. Gracias Rafa por los viajes a Cañamero. Gracias también al resto de miembros del Departamento de Edafología que en un momento u otro siempre han estado para ayudarme con alguna cosa. En especial, gracias a Alberto Masaguer por solucionar tantas necesidades de hoy para mañana y a Carmen Diéguez por ayudarme con la infinidad de trabas burocráticas que se presentan durante un doctorado.

Gracias también a Eugenio Díaz-Pinés. Con él empecé a caminar en la investigación durante mi TFC y desde entonces hasta ahora siempre ha estado dispuesto a ayudarme en infinidad de ocasiones para sacar manuscritos adelante, resolviéndome dudas o lo que fuese preciso. Un verdadero lujo contar con su ayuda. I would also like to thank the "Center of Stable Isotopes" from the IMK-IFU in Garmisch-Partenkirchen, particularly to Michael Dannenmann. Thanks a lot for helping me with the analyses of hundreds of ${ }^{15} \mathrm{~N}$ samples during the last years. I feel that I have learnt something new in each and all my stays in Garmisch.

Muchas gracias también a Mirjam Pulleman y Jacobo Arango por abrirme la puerta de sus grupos de investigación, sus proyectos y sus conocimientos. He aprendido mucho, he disfrutado mucho, he conocido gente fantástica y además, creo que alguna que otra cosa interesante hemos investigado. Ojalá podamos seguir trabajando juntos en el futuro porque estas experiencias son lo mejor de esta carrera. Gracias también a 
Yamileth Chaguezá, Enna Díaz, César Botero y Ashly Arévalo por abrirme la puerta de sus laboratorios y perdón por tanto desastre y suciedad. Me dejo sin nombrar a mucha buena gente de CIAT, pero si tuviese que citar a todos esto ocuparía cinco páginas.

Thanks also to Giancarlo Renella for his inestimable help, his extensive knowledge helped me to focus this thesis and a great part of it has been done thanks to his advices. Thanks Giancarlo for opening the door of CREA where I have learnt a lot about molecular techniques in soils. Thanks also to Alessandra Lagomarsino for her help with the GHG measurements and to Roberta Pastorelli for her time helping us with the molecular biology analysis. Without all of them, this thesis would have been different and, for sure, shorter.

Y por supuesto, muchas gracias a mis padres por apoyarme en esta loca vida que he llevado durante el doctorado yendo de un lado para otro y también, por su colaboración llevando reactivos químicos ocultos en maletas, muestras de suelo en el maletero del coches etc. Poco menos que han sido miembros de mi equipo de investigación. Gracias también a mis amigos por seguir estando en la brecha a pesar de que en estos años me he pasado la vida de un lado para otro en lugar de estar al pie del cañón.

Por último y lo más importante. Quiero dar gracias infinitas gracias a Nikola Teutscherova por acompañarme en esta aventura, porque esta tesis es tan suya como mía. Sin su ayuda, seguramente no estaría ahora escribiendo estas líneas. He aprendido muchísimo de su brillantez, de su capacidad de trabajo, de su valentía para lanzarse a ensayos que daban vértigo sólo de pensarlos. Ojalá sigamos mucho tiempo mano a mano. También quiero agradecer su colaboración a Frita Teutscherova, ya que en todas las horas que hemos pasado caminando juntos por medio mundo he podido encontrar aquella idea que me faltaba para una discusión o un orden mejor para unos párrafos.

Quisiese citar a muchas personas más que en algún momento u otro me han ayudado a sacar esta tesis adelante, pero siempre me seguiría faltando alguien, luego por no extenderme más, GRACIAS TOTALES. 


\section{LIST OF ABBREVIATIONS}

\begin{tabular}{|c|c|}
\hline AIC & Akaike's Information criteria \\
\hline $\mathrm{Al}^{3+}$ & exchangeable aluminium \\
\hline $\mathrm{AMF}$ & arbuscular mycorrhizal fungi \\
\hline $\mathrm{AOA}$ & ammonia oxidizing archea \\
\hline $\mathrm{AOB}$ & ammonia oxidizing bacteria \\
\hline ASase & arylsulphatase \\
\hline a.s.l.. & above sea level \\
\hline BAA & $\mathrm{N}-\alpha$-benzoyl-L-argininamide protease \\
\hline $\mathrm{BR}$ & basal respiration \\
\hline $\mathrm{C}$ & carbon \\
\hline $\mathrm{Ca}$ & Calcium \\
\hline CBS & converter basic slag \\
\hline CFI & comparative fit index \\
\hline DGGE & denaturation gradient gel electrophoresis \\
\hline DHase & dehydrogenase \\
\hline dNTPs & deoxynucleotid triphosphate \\
\hline DOC & dissolved organic carbon \\
\hline DON & dissolved organic nitrogen \\
\hline EAs & enzymatic activities \\
\hline $\mathrm{EC}$ & electrical conductivity \\
\hline EE- GRSP & easily extractable glomalin-related soil protein \\
\hline $\mathrm{EN}$ & extractable nitrogen \\
\hline $\mathrm{FC}$ & field capacity \\
\hline $\mathrm{F}: \mathrm{B}$ & fungi-to-bacteria ratio \\
\hline GHG & greenhouse gasses \\
\hline Glm & $\beta$-glucosaminidase \\
\hline Gls & $\beta$-glucosidase \\
\hline GRSP & glomalin-related soil protein \\
\hline GWC & gravimetric water content \\
\hline INT & 2-(4-Iodophenyl)-3-(4-nitrophenyl)-5-phenyltetrazolium chloride \\
\hline LMM & linear mixed model \\
\hline LSD & least significant difference \\
\hline
\end{tabular}




$\begin{array}{ll}\text { Mg } & \text { Magnesium } \\ \text { MBC } & \text { microbial biomass carbon } \\ \text { MBN } & \text { microbial biomass nitrogen } \\ \text { N } & \text { nitrogen } \\ \text { NN } & \text { net nitrification } \\ \text { NNM } & \text { net nitrogen mineralization } \\ \text { NT } & \text { no-tillage } \\ \text { P } & \text { phosphorous } \\ \text { PCA } & \text { principal component analysis } \\ \text { Phase } & \text { acid phosphomonoesterase activity } \\ \text { POM } & \text { particulate organic matter } \\ \text { PoxC } & \text { permanganate oxidizable carbon } \\ \text { RF } & \text { rock fragments } \\ \text { RG } & \text { red gysum } \\ \text { RMSEA } & \text { root mean square of approximation } \\ \text { RT } & \text { reverse transcription } \\ \text { S } & \text { sulphur } \\ \text { SEM } & \text { structural equation model } \\ \text { SRMR } & \text { standardized root mean square residual } \\ \text { SF } & \text { sugar beet foam } \\ \text { SOC } & \text { soil organic carbon } \\ \text { SOM } & \text { soil organic matter } \\ \text { TN } & \text { total nitrogen } \\ \text { TT } & \text { traditional tillage } \\ & \end{array}$




\section{LIST OF TABLES}

Table 3.2.1: $\quad$ Soil properties of a representative profile in the experimental area

Table 3.2.2: Chemical composition of used amendments

Table 3.2.3: Summary of liming amendments dates of application, amount and form of application

Table 3.2.4: Target genes (AOA, AOB, 16S, ITS), used primers and qPCR conditions

Table 3.2.5: Target genes (AOA, AOB, nirK, nirS, nosZ), used primers and qPCR conditions

Table 3.2.6: $\quad$ PCR primers and annealing temperatures used for DGGE analysis

Table 3.2.7: Initial properties of the soil used for the rewetting experiment

Table 3.2.8 Target genes, used primers and qPCR conditions

Table 3.2.9: Correlation matrix of the chemical and biological parameters determined in the study. The top part of the matrix indicates correlation coefficients and the bottom part the level of significance.

Table 4.1.1: Maximum, minimum and mean monthly soil temperatures between November 2014 and October 2015 at $5 \mathrm{~cm}$ depth

Table 4.1.2: $\quad$ The content of $\mathrm{SOC}, \mathrm{POxC}$ and soil $\mathrm{pH}$

Table 4.1.3 Scores of PC1 and PC2 in the PCA of all sampling dates

Table 4.2.1: Soil $\mathrm{pH}$, soil organic carbon (SOC), total soil nitrogen (TN), gravimetric water content (GWC), water-filled pore space (WFPS) and dehydrogenase activity (DHase)

Table 4.2.2: Effects of sampling date, tillage and amendment application on ammonium and nitrate content, gross ammonification (gross ammon), gross nitrification (gross nitr), ammonium $\left(\mathrm{NH}_{4}{ }^{+} \mathrm{immob}\right)$ and nitrate $\left(\mathrm{NO}_{3}{ }^{-}\right.$immob) immobilization rates, dissolved organic carbon (DOC), dissolved organic nitrogen (DON), microbial biomass carbon (MBC) and microbial biomass nitrogen (MBN)

Table 4.2.3: Effects of sampling time, tillage and amendment application on number of gene copies of $16 \mathrm{~S}$, ITS, AOA-amoA AOB-amoA and the ratio ITS:16S

Table 4.2.4 Multiple regression analysis to identify the main factors affecting the $\mathrm{N}$ gross transformation and the abundance of nitrifiers. The values are constants or coefficients in the fitted equation $\mathrm{Y}=\mathrm{a}+\mathrm{bx}_{1}+\mathrm{cx}_{2}+\mathrm{dx}_{3} \ldots$ where $\mathrm{Y}$ is the dependent variable and $\mathrm{x}_{1}, \mathrm{x}_{2}, \mathrm{x}_{3} \ldots$ are the independent variables 
Table 4.3.1: Cumulative $\mathrm{N}_{2} \mathrm{O}$ emissions of the four treatments at $50 \%$ and $100 \%$ of $\mathrm{FC}$ and the effects of moisture (50\% FC vs $100 \% \mathrm{FC}$ ) tillage practice (NT vs TT) and Liming (amended vs. not amended) and their interactions

Table 4.3.2: $\quad$ ANOSIM and PERMANOVA global test based on the DICE similarity matrices derived from DGGE band profile

Table 4.3.3: Average species richness and Shannon -Weiner diversity index calculated on DGGE band profiles of selected genes and effect of tillage practice, amendment and their interaction.

Table 4.3.4: $\quad$ Effect of moisture (50\% FC vs $100 \%$ FC) tillage practice (NT vs TT) and liming (amended vs. not amended) and their interactions on the abundance of nirK gene cDNA.

Table 4.4.1. The effects of soil depth (Dpt), tillage (T) and amendment (A) on organic matter and soil carbon fractions, soil $\mathrm{pH}$ and base cations

Table 4.4.2. The effects of depth (D), tillage (T) and amendment (A) on microbial indicators

Table 4.4.3. The effects of depth (D), tillage (T) and amendment (A) on soil $\mathrm{C}$ mineralization and net $\mathrm{N}$ mineralization

Table 4.5.1: $\quad$ Effects Liming (A), tillage (T) and depth (Dpt) on soil enzyme activity and microbial biomass

Table 4.5.2: $\quad$ The content of dissolved organic $C$ (DOC), extractable $N(E N)$, and extractable carbohydrates ( Carb $\left._{\text {ex }}\right)$ as affected by Liming $(\mathrm{A})$, tillage $(\mathrm{T})$ and soil depth (Dpt)

Table 4.5.3: Principal component loadings for measured soil parameters

Table 4.6.1: Soil organic matter fractions and enzymatic activities at the three samplings. Mean \pm standard error of the mean $(n=4)$.

Table 4.6.2: $\quad$ Selected soil chemical properties at the three samplings. Mean \pm standard error of the mean $(n=4)$.

Table 4.6.3: Effects of tillage (T), Liming (A) and date (D) on mycorrhizal root colonization, plant biomass and foliar $\mathrm{N}$ and $\mathrm{P}$ content

Table 4.6.4: Effect of tillage ( $\mathrm{T}$ ) and Liming (A) on plant nascence, harvest and $\mathrm{N}$ and $\mathrm{P}$ uptake

Table 5.1. Summary of proposed hypothesis for each objective and the justification of the obtained result. In blue, the confirmed hypothesis, in black those partially confirmed and in red the rejected hypothesis. 


\section{LIST OF FIGURES}

Fig 3.1.1: Aerial photography of Cañamero raña $(a, b)$ and the raña flat profile (c).

Fig 3.2.1: Olive orchards managed by tillage (a), natural revegetation after land abandonment (b) natural grassland in former cropland (c) a relict cork oak (d) and the soil surface gravel in detail (d).

Fig. 3.2.2: Lay-out of the field experiment

Fig. 3.2.3: Sample collection dates for all experiments included in the present thesis.

Fig. 3.2.4: A priori SEM of the hypothesized relationships between Tillage practices and the Amendment application and soil $\mathrm{C}$ and $\mathrm{N}$ mineralization and net nitrification. The endogenous variables are represented into squares and the latent variables are represented into circles.

Fig. 3.2.5: Daily mean air and soil temperatures and precipitations during the study period from sowing (November $11^{\text {th }} 2015$ ) to the harvest (May $31^{\text {st }} 2016$ ).

Fig. 4.1.1. Precipitation, minimum temperature, maximum temperature and mean temperature for the study period (2014-2015) and the historical data of precipitation and mean temperature for the period 1961-1990.

Fig. 4.1.2 Gravimetric soil water content (GWC) of treatments grouped in traditional tillage (TT) or no-tillage (NT) $(\mathrm{n}=8)$ at the depth of $0-5 \mathrm{~cm}$ and $5-10 \mathrm{~cm}$ during the 2014-2015 study season.

Fig. 4.1.3. Microbial biomass $C(a, b)$, microbial biomass $N(c, d)$ and basal respiration $(e, f)$, in $0-5 \mathrm{~cm}$ soil layer $(\mathrm{a}, \mathrm{c}, \mathrm{e})$ and $5-10 \mathrm{~cm}$ soil layer $(\mathrm{b}, \mathrm{d}, \mathrm{f})$.

Fig. 4.1.4: The activity of six enzymes catalyzing key nutrient transformation processes in 0-5 cm soil layer (a, c, e, g, I, k) and 5-10 cm soil layer (b, d, f, h, j, l).

Fig. 4.1.5: Loading plots for soil properties and microbial parameters on Principal Components.

Fig. 4.1.6: PCA loading plots of the sampled soils based on arylsulphatase, glucosidase, glucosaminidase, dehydrogenase, phosphatase and urease activity, basal respiration, soil organic carbon and permanganate oxidizable carbon content, $\mathrm{pH}$ value, carbon and nitrogen of microbial biomass, gravimetric water content and mean gravimetric water content for the three months prior to soil sampling.

Fig. 4.2.1: Daily air and soil temperatures and precipitations. Data obtained from Guadalupe meteorological station.

Fig. 4.2.2 Gross ammonification rate (a), gross nitrification rate (b), ammonium (c) and nitrate (d) immobilization rate, microbial biomass carbon (e), microbial biomass nitrogen (f), dissolved organic carbon ( $\mathrm{g}$ ), dissolved organic nitrogen (h), ammonium (i) and nitrate (j) content for both sampling dates. 
Fig. 4.2.3 The abundance of $16 \mathrm{~S}$ (a), ITS (b), AOA-amoA (c) and AOB-amoA (d) gene copies and the ITS:16S ratio (e) determined during both sampling events.

Fig. 4.3.1: Soil moisture evolution during the incubation study at 50\% FC (A) and $100 \%$ FC (B), cumulative $\mathrm{N}_{2} \mathrm{O}$ emissions during the incubation period at $50 \% \mathrm{FC}(\mathrm{C})$ and $100 \% \mathrm{FC}(\mathrm{D})$, and $\mathrm{N}_{2} \mathrm{O}$ hourly fluxes during the first $36 \mathrm{~h}$ after rewetting at $50 \% \mathrm{FC}(\mathrm{E})$ and $100 \% \mathrm{FC}(\mathrm{E})$.

Fig 4.3.2: Nitrifiers and denitrifiers abundance in the initial soil reported as amoA, nirK, nirS, and nosZ gene copy numbers per gram of dry soil.

Fig. 4.3.3: UPGMA and nMDS analysis of AOA-amoA, AOB-amoA, nirK, nirS and nos $Z$ gene DGGE profiles obtained from the initial soil.

Fig. 4.3.4: nirK gene expression reported as nirK gene cDNA copy number per gram of dry soil after $2 \mathrm{~h}$ and $24 \mathrm{~h}$ of soil rewetting at $50 \%$ FC and $100 \%$ FC

Fig. 4.4.1. Soil respiration ( $a, b)$ and cumulative $\mathrm{CO}_{2}-\mathrm{C}$ production $(\mathrm{c}, \mathrm{d})$ of $0-5 \mathrm{~cm}(\mathrm{a}$, c) and $5-10 \mathrm{~cm}(\mathrm{~b}, \mathrm{~d})$ soil layer.

Fig. 4.4.2. The contents of $\mathrm{NH}_{4}{ }^{+}-\mathrm{N}(\mathrm{a}, \mathrm{b}), \mathrm{NO}_{3}{ }^{-} \mathrm{N}(\mathrm{c}, \mathrm{d})$ and total inorganic nitrogen (TIN) $(\mathrm{e}, \mathrm{f}))$ of $0-5 \mathrm{~cm}(\mathrm{a}, \mathrm{c}, \mathrm{e})$ and $5-10 \mathrm{~cm}(\mathrm{~b}, \mathrm{~d}, \mathrm{f})$ soil layer.

Fig. 4.4.3: The structural equation model (SEM) of the hypothesized relationships between Tillage practices and the Amendment application and soil $\mathrm{C}$ and $\mathrm{N}$ mineralization and net nitrification.

Fig. 4.5.1: The activity of casein protease, BAA protease and $\beta$-glucosidase, microbial biomass carbon (MBC), microbial biomass nitrogen (MBN), soil $\mathrm{pH}$, total organic carbon (TOC), total nitrogen (TN), C:N ratio potentially mineralizable nitrogen $(\mathrm{PMN})$ and extractable Bradford-reactive soil protein (EE-GRSP) as affected by tillage and Liming in three soil depths.

Fig. 4.5.2: Loading plots for measured soil parameters in Principal Components.

Fig. 4.5.3: The C:N ratio of plant aboveground biomass (a), total biomass production (b) and the relationship between biomass $\mathrm{C}: \mathrm{N}$ ratio and the casein protease:BAA protease ratio (c).

Fig. 4.6.1. Mycorrhizal root colonization $(a, b)$, foliar $N$ content $(c, d)$, foliar $P$ content $(\mathrm{e}, \mathrm{f})$ and $\mathrm{N}: \mathrm{P}$ ratio $(\mathrm{g}, \mathrm{h})$ of oat $(\mathrm{a}, \mathrm{c}, \mathrm{e}, \mathrm{g})$ and vetch plants $(\mathrm{b}, \mathrm{d}, \mathrm{f}, \mathrm{h})$. 


\begin{abstract}
Loss of soil organic carbon (SOC) and soil acidification as a result of unsustainable agronomic practices are two of the main concerns of the present agriculture at global scale, affecting food security and environmental quality. Recently, adoption of more environmental-friendly techniques, and conservation agriculture in particular, has been identified as a suitable practice for restoring the fertility of degraded soils. In the case of acid degrades soils, the combination of no-tillage (NT) with surface lime application has been shown to restore the SOC pools, improve soil physical properties and soil-water relationships, alleviate the acidity and $\mathrm{Al}^{3+}$ toxicity, and increase crop yields. Nevertheless, as several important aspects of the combined application of NT with surface liming has not been addressed by the previous research, this thesis aims at filling these knowledge gaps and at identifying the interactive effects of NT and liming on soil microbial activity and carbon $(\mathrm{C})$ and nitrogen $(\mathrm{N})$ cycling with a special emphasis on the seasonality of the Mediterranean climate.
\end{abstract}

An exhaustive literature review prior to this thesis identified six gaps of knowledge, which were summarized in: (i) soil biological properties and their evolution during the year under Mediterranean climate, (ii) the impact of NT and liming on N transformation during the summer fallow period and (iii) the subsequent rewetting event, (iv) the combined effect of both practices on $\mathrm{C}$ and $\mathrm{N}$ mineralization and (v) soil protease activity and $\mathrm{N}$ availability, and (vi) on the plant symbiotic interactions with arbuscular mycorrhiza fungi (AMF) and nutrient uptake. To address these underinvestigated topics, specific experiments were designed and performed in the long-term experimental field located in the Cañamero raña in Cáceres (SW Spain). The Cañamero experimental site/field was established in 2005 and NT, as an alternative to traditional tillage (TT), and liming were combined in a full factorial design. A mixture of oat (Avena sativa L.) and vetch (Vicia sativa L.) was cropped every season for forage under rainfed conditions.

The first experiment evaluated the soil enzymatic activity and microbial biomass in four different sampling times during the same year (January, April, July, October) aiming to evaluate the interaction between the treatments and the Mediterranean seasonality. The results showed a general increase of soil microbial biomass and enzymatic activity in the topsoil of NT treatments which was related to the increase of 
SOC and the amelioration of the extreme drought during several water-limited months. However, liming slightly affected soil enzymatic activities, decreased the microbial biomass $\mathrm{C}$ and increased microbial biomass $\mathrm{N}$, which suggests as a shift in the microbial communities. The amelioration of drought under NT probably caused the maintenance of higher microbial biomass and enzymatic activity during the summer period and, thus, increased soil microbial resilance to drought stress.

A second experiment aimed at addressing the impact of NT and liming on the gross $\mathrm{N}$ transformation rates during the summer fallow period using ${ }^{15} \mathrm{~N}$ pool dilution technique. Liming increased both gross $\mathrm{N}$ mineralization and nitrification while traditional tillage increased gross $\mathrm{N}$ immobilization. Tillage did not affect gross nitrification but the effect of liming on gross $\mathrm{N}$ mineralization was enhanced in NT plots. During the summer fallow, mineralization, nitrification and microbial immobilization decreased and ammonium was accumulated, probably as a consequence of the decoupling between production and consumption rates of ammonium. The increase of gross $\mathrm{N}$ mineralization and nitrification caused by liming enhances the risk of $\mathrm{N}$ losses via nitrate leaching and gaseous losses after soil rewetting in autumn, especially when combined with NT.

The third experiment focused on the evaluation of the effects of both agronomic practices on the $\mathrm{N}_{2} \mathrm{O}$ emissions after soil rewetting at the end of the summer fallow, and the interplay of soil microbes. Soil samples from the experimental field were rewetted in laboratory under controlled conditions and the soil-atmosphere $\mathrm{N}_{2} \mathrm{O}$ fluxes were determined periodically. Liming application reduced the cumulative $\mathrm{N}_{2} \mathrm{O}$ emission by more than $60 \%$ respect to the unamended soil after soil re-wetting. These findings show the usefulness of liming to mitigate the $\mathrm{N}_{2} \mathrm{O}$ emission after the summer rains in Mediterranean areas. Further, I found high impact of liming on the size, structure and transcription of selected microbial populations involved the $\mathrm{N}$ cycle and $\mathrm{N}_{2} \mathrm{O}$ emissions. The high transcription rate of nirK-bearing microbes and the absence of nitrifier transcription during the $\mathrm{N}_{2} \mathrm{O}$ peak suggest that the $\mathrm{N}_{2} \mathrm{O}$ was originated by denitrification rather than by nitrification. In addition, the strong stimulation of $\operatorname{nirK}$ transcription by liming indicates that the mechanism by which liming suppress the $\mathrm{N}_{2} \mathrm{O}$ emission was related with changes in the denitrification process.

The fourth experiment aimed to understand the interactive effects on $\mathrm{C}$ and $\mathrm{N}$ cycling and their combined effect on microbial indicators using a Structural Equation 
Model (SEM). The SEM revealed that $\mathrm{C}$ mineralization was only affected by tillage practices while net $\mathrm{N}$ mineralization was increased by $\mathrm{NT}$ and liming amendment. The absence of relevant effects of amendment on $\mathrm{C}$ mineralization suggests a possible decoupling between the $\mathrm{C}$ and $\mathrm{N}$ mineralization processes with potential implications for $\mathrm{N}$ losses. In addition, SEM revealed that the impact of tillage practice on $\mathrm{C}$ and $\mathrm{N}$ mineralization was mediated by changes in the microbial biomass, which highlights the importance of the inclusions of microbial parameters in the nutrient cycling studies as affected by agronomic practices.

The fifth experiment was designed to understand the effect of tillage practice and liming on depolymerization of organic proteinaceous compounds, a critical step of $\mathrm{N}$ cycling in agroecosystems. The activity of soil casein protease (an enzyme degrading high-molecular weight proteinaceous compounds), $\mathrm{N}$ - $\alpha$-benzoyl-L-argininamide protease (BAA) (targeting low-molecular weight compounds) was determined in three soil layers. Higher casein protease and a lower BAA protease activity was observed in limed plots This imbalance in enzymatic activity, together with an observed reduced extractable organic $\mathrm{C}$ and microbial biomass $\mathrm{C}$ in limed plots suggests a reduced microbial immobilization of mineral N. Such situation may result in an accumulation of intermediate metabolic products (i.e. monomers and amino acids), therefore inducing reduced mineral $\mathrm{N}$ losses and/or changes in $\mathrm{N}$ acquisition preferences by plants.

The sixth and last experiment analyzed the impact of NT and liming on plant AMF mycorrhization and the effects on plant growth and $\mathrm{N}$ and $\mathrm{P}$ contents during three growth stages of oat and vetch. The oat plant biomass and $\mathrm{N}$ content were increased by NT and liming while vetch biomass and N content was increased only by liming throughout the whole growing season. In addition, AMF root colonization of both crops was higher under NT and limed plots, despite of the relatively high content of available $\mathrm{P}$ in all treatments. The alleviation of soil acidity and enhancement of soil properties related with NT previously described, linked with the higher plant mycorrhization, suggests that, under Mediterranean conditions, the combination of these two common agronomic practices may increase both yields and nutrient use efficiency in acid soils.

In conclusion, this thesis shows that the combination of NT and liming is a sustainable practice to restore acid degraded soils, enhancing the microbial activity and stimulating soil $\mathrm{C}$ and $\mathrm{N}$ cycling. In addition, the thesis revealed the impact of both agronomic practices in the summer fallow period characteristic of the Mediterranean 
climate which is critical for $\mathrm{N}$ losses. The obtained results show the usefulness of liming to reduce the $\mathrm{N}_{2} \mathrm{O}$ emission after the summer rains both higher $\mathrm{N}$ uptake by crops, which suggests a mitigation of the negative environmental effects of agriculture. This thesis may contribute to promote the adoption of more suitainable agronomic practices in acid soils under Mediterranean conditions as well as to identifying and understanding of their potential environmental impacts. 


\section{RESUMEN}

La pérdida de carbono orgánico del suelo (COS) y la acidificación de los suelos a causa de prácticas agronómicas insostenibles son dos de los mayores problemas a los que se enfrenta la agricultura a nivel global, afectando la seguridad alimentaria y la calidad ambiental. Recientemente, la adopción de técnicas más amigables con el medio ambiente, y en particular la agricultura de conservación, han sido identificadas como prácticas adecuadas para restaurar la fertilidad de suelos degradados. En el caso de suelos ácidos degradados, la combinación de no-laboreo (NL) con la aplicación de caliza en superficie ha demostrado ser capaz de restaurar el contenido de COS, mejorar las propiedades físicas y la relación suelo-agua, aliviar la toxicidad por $\mathrm{Al}^{3+} \mathrm{e}$ incrementar los rendimientos de los cultivos. Sin embargo, existen aspectos importantes de la aplicación combinada de NT y aplicación superficial de caliza que no han sido todavía evaluados, por lo que esta tesis aspira a llenar esas lagunas de conocimiento y a identificar los efectos interactivos del NL y la aplicación de caliza en la actividad microbiana del suelo y el ciclo del carbono (C) y nitrógeno $(\mathrm{N})$ con especial énfasis en las particulares condiciones que suponen la estacionalidad del clima Mediterráneo.

Una revisión literaria exhaustiva previa al inicio de la tesis identificó seis lagunas de conocimiento, la cuales se resumen en: (i) propiedades biológicas del suelo y su evolución durante un año bajo condiciones de clima Mediterráneo, (ii) el impacto del NL y las enmiendas calizas durante el periodo de barbecho estival, (iii) el subsiguiente humedecimiento del suelo, (iv) el efecto combinado de ambas prácticas en la mineralización de $\mathrm{C}$ y $\mathrm{N}$, (v) la actividad de las proteasas y la disponibilidad de $\mathrm{N}$ en el suelo, y (vi) en la interacción simbiótica con los hongos micorrícicos arbusculares (HMA) y la toma de nutrientes por los cultivos. Para solventar esos temas pobremente estudiados, seis experimentos específicos fueron diseñados y llevados a cabo en un campo experimental de larga duración situado en la Raña de Cañamero, Cáceres (Sudoeste España). El campo de experimentación de Cañamero se estableció en 2005 y el NL, como alternativa al laboreo tradicional, y la enmienda caliza se combinaron en un diseño factorial. Una mezcla de avena (Avena sativa L.) y veza (Vicia sativa L.) se cultivó cada temporada bajo condiciones de secano.

El primer experimento trató de evaluar la actividad enzimática y la biomasa microbiana en cuatro periodos de muestreo durante el mismo año (enero, abril, julio y 
octubre) con el propósito de evaluar la interacción entre los tratamientos y la estacionalidad. Los resultados mostraron un incremento general de la actividad enzimática y la biomasa microbiana en la parte superior del suelo en los tratamientos de NL, lo cual, se relacionó con el incremento del COS y la disminución de las condiciones de sequía extrema durante los meses de déficit hídrico. Sin embargo, la enmienda caliza afectó ligeramente las actividades enzimáticas y redujo el $\mathrm{C}$ de la biomasa microbiana e incremento el $\mathrm{N}$ de la misma, lo cual sugiere un cambio en las comunidades microbianas. El alivio de las condiciones de sequía en NL probablemente causó el mayor mantenimiento de la biomasa microbiana y las actividades enzimáticas durante el periodo de verano, y, por lo tanto, incrementó la resiliencia microbiológica del suelo al estrés hídrico.

Un segundo experimento aspiró a escudriñar el impacto del NL y la enmienda caliza en las tasas brutas de transformaciones de $\mathrm{N}$ durante el periodo de barbecho usando la técnica de dilución isotópica del ${ }^{15} \mathrm{~N}$. La enmienda caliza incremento tanto la mineralización de $\mathrm{N}$ con la nitrificación bruta, mientras que el laboreo tradicional incrementó la inmovilización de N. El laboreo no afectó la nitrificación bruta pero el efecto de la enmienda en la mineralización bruta de $\mathrm{N}$ se incrementó al combinarse con el NL. A lo largo del periodo de barbecho estival, la mineralización, la nitrificación y la inmovilización microbiana decrecieron y el amonio se acumuló en suelo, probablemente como consecuencia de un desacople entre su producción y su consumo . El incremento de la mineralización de $\mathrm{N}$ y la nitrificación bruta causada por la enmienda caliza podría incrementar el riesgo de pérdidas de $\mathrm{N}$, bien vía lixiviación, o bien mediante emisiones gaseosas tras el rehumedecimiento otoñal, especialmente en el caso de su combinación con NL.

El tercer experimento se enfocó en estudiar de los efectos de ambas prácticas agronómicas en las emisiones de $\mathrm{N}_{2} \mathrm{O}$ tras el rehumedecimiento del suelo tras el barbecho estival y el rol en el mismo de los microorganismo del suelo. Muestras de suelo del campo experimental fueron rehumedecidas en laboratorio bajo condiciones controladas y los flujos suelo-atmósfera de $\mathrm{N}_{2} \mathrm{O}$ fueron determinado de forma periódica. La enmienda caliza redujo las emisiones acumuladas de $\mathrm{N}_{2} \mathrm{O}$ en más de un $60 \%$ respecto a los suelos sin enmendar tras el rehumedecimiento del suelo. Estos resultados muestran la utilidad de la enmienda caliza para mitigar las emisiones de $\mathrm{N}_{2} \mathrm{O}$ tras lluvias veraniegas en áreas Mediterráneas. Así mismo, se encontró un gran efecto de la 
enmienda caliza en el tamaño, estructura y transcripción de poblaciones microbianas implicadas en el ciclo del $\mathrm{N}$ y las emisiones de $\mathrm{N}_{2} \mathrm{O}$. La mayor tasa de trascripción de los microorganismos portadores de nirK y la ausencia de transcripción en los nitrificantes durante el pico de emisiones de $\mathrm{N}_{2} \mathrm{O}$ sugiere que el $\mathrm{N}_{2} \mathrm{O}$ fue más bien derivado del proceso de denitrificación que del proceso de nitrificación. Además, la fuerte estimulación de la transcripción de nirK provocada por la enmienda caliza indica que el mecanismo por el cual la enmienda reduce las emisiones de $\mathrm{N}_{2} \mathrm{O}$ está relacionado con cambios en el proceso de denitrificación.

El cuarto experimento partió con la premisa de entender los efectos interactivos en el ciclo del $\mathrm{C}$ y el $\mathrm{N}$ y su efecto combinado en indicadores microbiológicos usando un Modelo de Ecuación Estructural (MEE). El MEE reveló que la mineralización de C se vio solamente afectada por la práctica de labranza, mientras que la mineralización neta de $\mathrm{N}$ se incrementó por el NL y la enmienda caliza. La ausencia de efectos relevantes de la enmienda en la mineralización de $\mathrm{N}$ sugiere un desacople entre los procesos de mineralización de $\mathrm{C}$ y $\mathrm{N}$ con implicaciones potenciales en la pérdida de $\mathrm{N}$. Además, el MEE reveló que el impacto del tipo de laboreo en la mineralización de $\mathrm{C}$ y $\mathrm{N}$ fue interpuesto a través de cambios en la biomasa microbiana, lo cual, pone de manifiesto la importancia de la inclusión de parámetros microbiológicos en los estudios de ciclos de nutrientes.

El quinto experimento fue diseñado con la pretensión de entender el efecto del tipo de práctica de labranza y de la enmienda caliza en la depolimerización de los compuestos orgánicos proteicos, un paso fundamente en el ciclo del $\mathrm{N}$ en los agrosistemas. La actividad de la proteasa caseína (una enzima que degrada compuestos proteicos de alto peso molecular) y la proteasa $\mathrm{N}$ - $\alpha$-benzoyl-L-argininamida (BAA) (encargada de los compuestos de bajo peso molecular) se determinó a tres diferentes profundidades en el suelo. Se observó en los tratamientos enmendados una mayor proteasa caseína y una menor BAA proteasa. Este desequilibrio en la actividad enzimática, unido a una reducción del $\mathrm{C}$ extraíble y $\mathrm{C}$ de la biomasa microbiana en los tratamientos enmendados sugiere una reducción de la inmovilización del $\mathrm{N}$ mineral por parte de la biomasa microbiana. Esta situación puede suponer una acumulación de productos metabólicos intermedios (tales como monómeros o aminoácidos) y por tanto, inducir una reducción de las pérdidas de $\mathrm{N}$ mineral y/o cambios en las preferencias adquisitivas por las plantas 
El sexto y último experimento analizó el impacto del NL y la enmienda caliza en la micorrización de las plantas y los efectos en el crecimiento de las mismas y su contenido en $\mathrm{N}$ y $\mathrm{P}$ a lo largo de tres estadios de crecimiento en avena y veza. La biomasa de avena y su contenido en $\mathrm{N}$ se vieron incrementados por el NL y la enmienda caliza, mientras que la biomasa de veza y su contenido en $\mathrm{N}$ sólo se vieron afectados por la enmienda a lo largo de toda la campaña. Además, la colonización por HMA de ambos cultivos fue mayor tanto en los tratamientos de NL como en los enmendados, más allá del relativamente alto contenido de fósforo disponible en todos los tratamientos. El alivio de la acidez del suelo y la mejora de propiedades del suelo a causa del NL previamente descritas, unido a la mayor micorrización de las plantas sugiere que, bajo condiciones Mediterráneas, la combinación de esas dos prácticas agronómicas comunes podría incrementar los rendimientos de ambos cultivos e incrementar la eficiencia en el uso de fertilizantes en suelos ácidos.

En conclusión, esta tesis muestra que la combinación de NL y las enmiendas calizas es una práctica sostenible para restaurar suelos ácidos degradados mejorando la actividad microbiológica del suelo y estimulando el ciclo del $\mathrm{C}$ y el $\mathrm{N}$ en suelos. Además, la tesis analizó el impacto de ambas prácticas agronómicas durante el periodo de barbecho estival característico del clima Mediterráneo, el cual es crítico en relación a las pérdidas de $\mathrm{N}$. Los resultados obtenidos demuestran la utilidad de las enmiendas calizas para mitigar las emisiones de $\mathrm{N}_{2} \mathrm{O}$ tras las lluvias de verano a la vez que incrementar la toma de $\mathrm{N}$ por los cultivos, lo cual sugiere una reducción de los impactos ambientales de la agricultura. Esta tesis podría contribuir a la adopción de prácticas agrícolas más sostenibles en suelos ácidos bajo condiciones mediterráneas, así como a identificar y entender sus posibles impactos ambientales. 


\section{TABLE OF CONTENTS}

$\overline{A C K N O W L E D G E M E N T S ~ . . . . . . . . . . . . . . . . . . . . . . . . . . . . . . . . . . . . . . . . . . . . . . . . . . . . . . . . . . . . . . . . . . . . . . . . . . . . . . . . . . . . . . . . . . . . . . . . . . . . . . . . . . . . . . . . . . . . . . . i ~}$

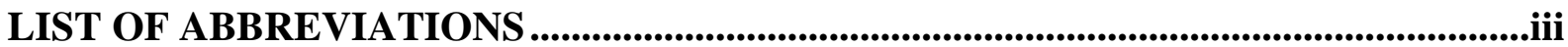

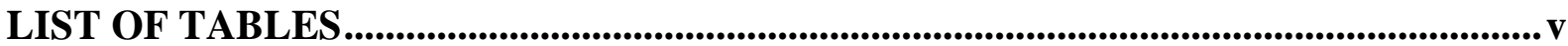

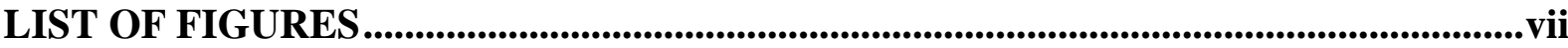

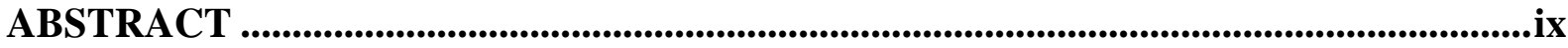

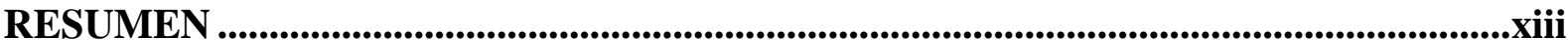

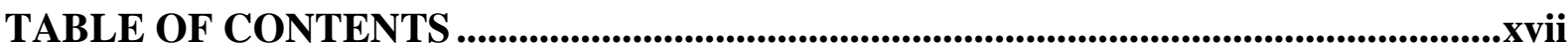

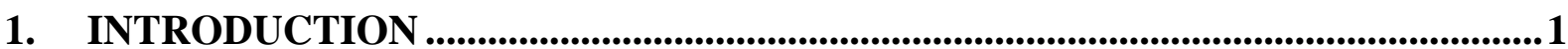

1.1. Soil degradation and agriculture in the Mediterranean region .................................. 1

1.2. No-tillage agriculture under Mediterranean climate ................................................ 4

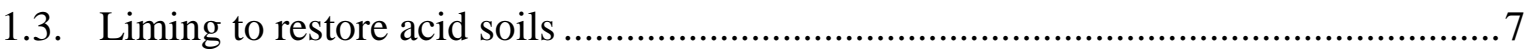

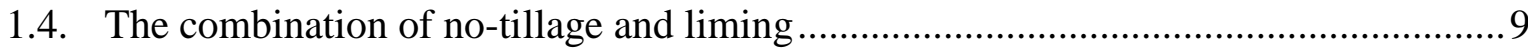

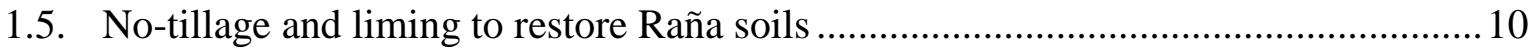

1.6. Seasonal variation of microbial activity as affected by tillage practice and

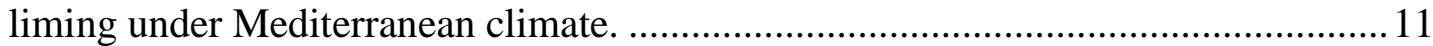

1.7. The interactive effect of NT and liming on gross $\mathrm{N}$ transformations rates during

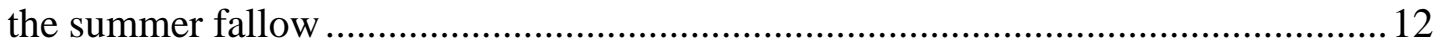

1.8. Impact of $\mathrm{NT}$ and liming in $\mathrm{N}_{2} \mathrm{O}$ emissions after soil rewetting................................. 14

1.9. Effects of $\mathrm{NT}$ and liming combination on soil and $\mathrm{C}$ and $\mathrm{N}$ mineralization............... 16

1.10. Soil protease activity and $\mathrm{N}$ supply in different soil layers as affected by NT

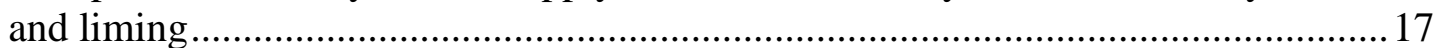

1.11. Effects of NT and liming on plant mycorrhization and crop performance ............... 19

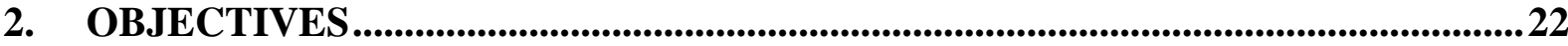

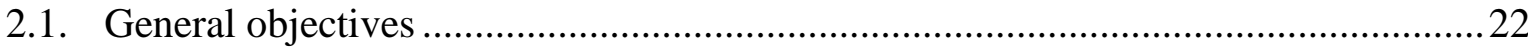

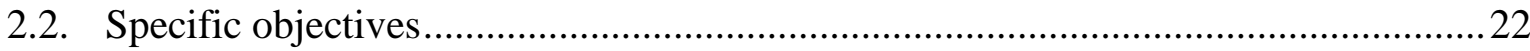

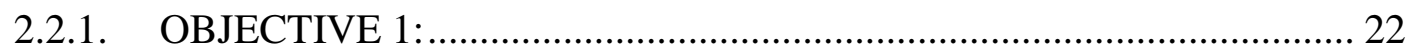

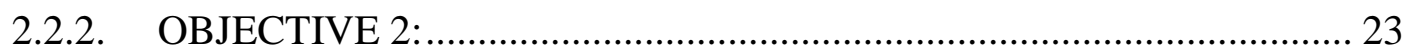

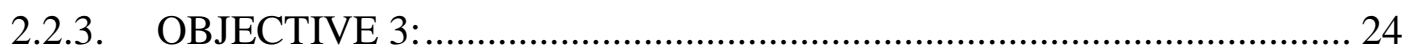

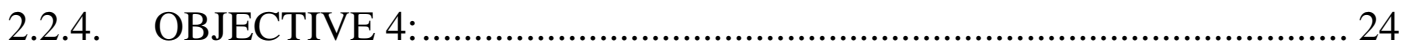

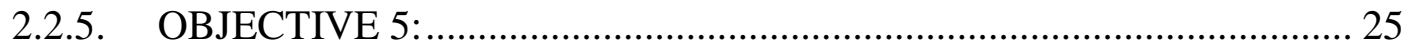

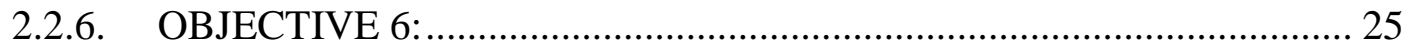

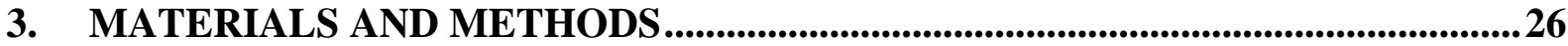

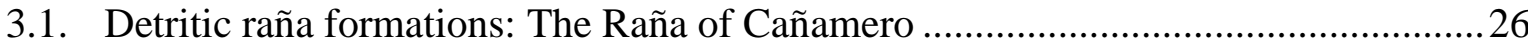

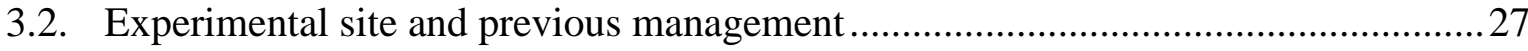


3.2.1. Previous land-use and experimental area establishment

3.2.2. Sampling scheme and particular experiments ................................. 31

3.2.3. Experiment 1: Seasonal variation of enzymatic and microbial activity ... 31

3.2.4. Experiment 2: Gross $\mathrm{N}$ transformation rates during summer fallow ....... 34

3.2.5. Experiment 3: Post re-wetting soil $\mathrm{N}_{2} \mathrm{O}$ emissions ............................... 38

3.2.6. Experiment 4: Effects of NT \& liming on carbon and nitrogen

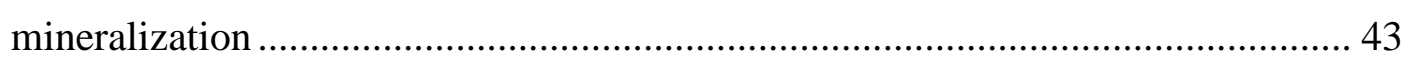

3.2.7. Experiment 5: Effect of NT, liming and depth on soil proteases ............. 48

3.2.8. Experiment 6: Effect of NT and liming on plant mycorrhization .............50

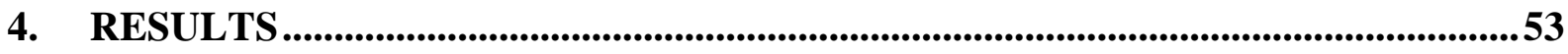

4.1. Experiment 1: Seasonal variation of microbial and enzymatic activity .....................53

4.1.1. Precipitations, soil water content and soil temperature ......................... 53

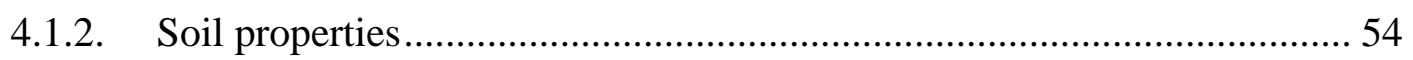

4.1.3. Microbial biomass and soil basal respiration .................................... 55

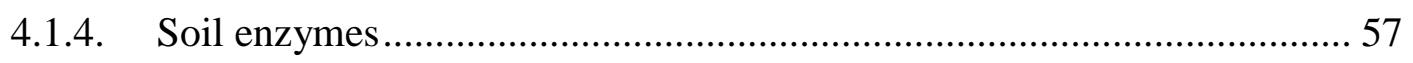

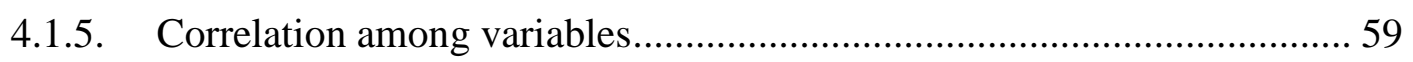

4.2. Experiment 2: Gross $\mathrm{N}$ transformation rates during summer fallow .........................64 64

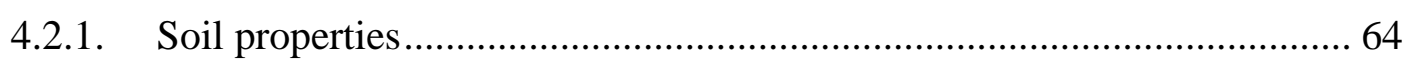

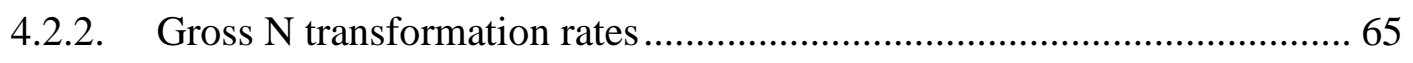

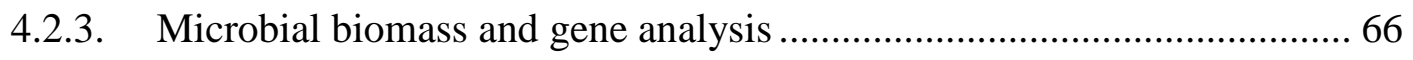

4.2.4. Correlation and controls of gross $\mathrm{N}$ transformations and microbiological

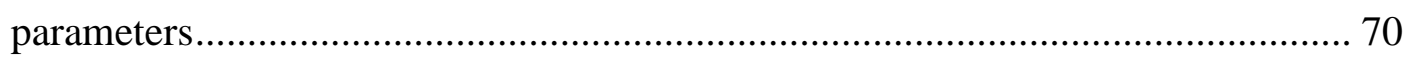

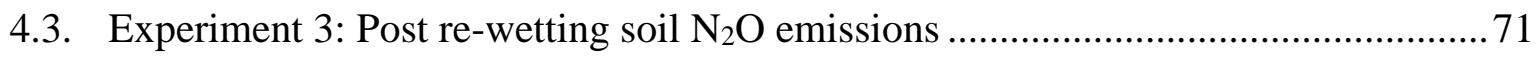

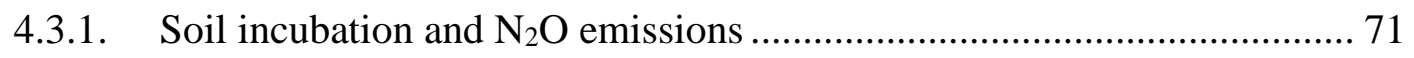

4.3.2. Initial nitrifier and denitrifier populations ….................................... 73

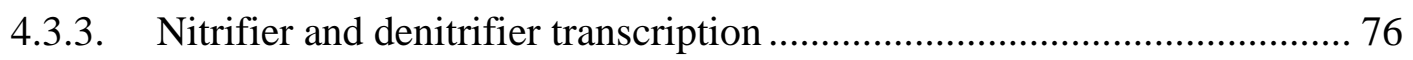

4.4. Experiment 4: Effects of NT and liming on carbon and nitrogen mineralization...... 78

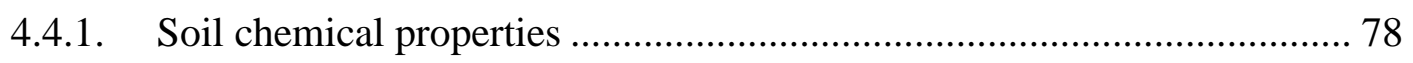

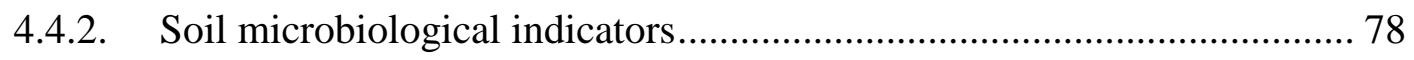




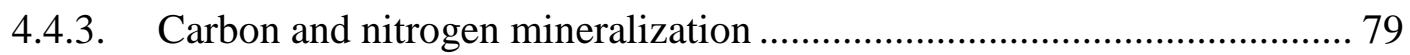

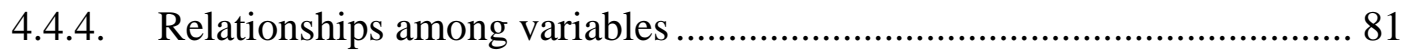

4.5. Experiment 5: Effect of NT, liming and depth on soil proteases ............................. 84

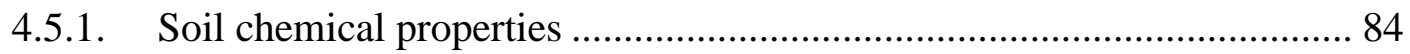

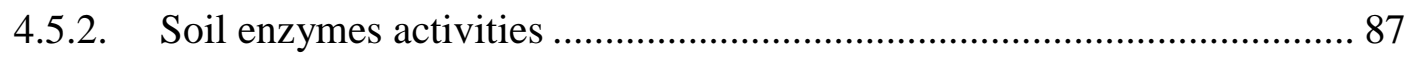

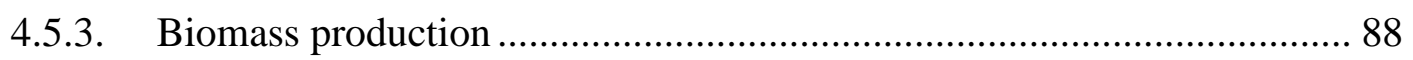

4.6. Experiment 6: Effect of NT and liming on plant mycorrhization .............................89

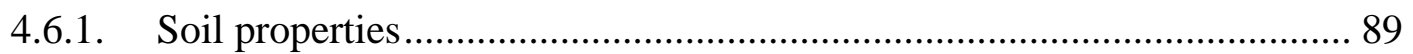

4.6.2. Oat plant growth and AMF colonization ............................................. 90

4.6.3. Vetch plant growth and AMF colonization ......................................... 92

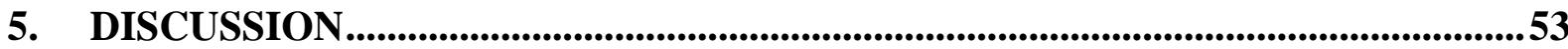

5.1. Experiment 1: Seasonal variation of microbial and enzymatic activity .....................53

5.1.1. Soil properties, soil moisture content and soil temperature .................... 53

5.1.2. The opposite effect of no-tillage and Liming on soil microbial biomass. 54

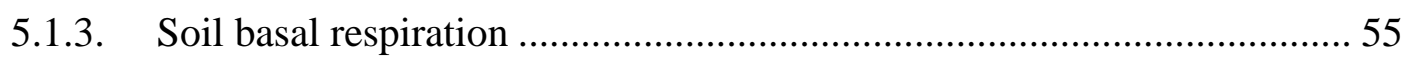

5.1.4. The influence of soil management in enzymatic activities .................... 56

5.2. Experiment 2: Gross $\mathrm{N}$ transformation rates during summer fallow 60

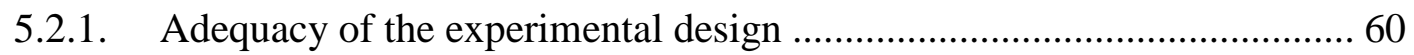

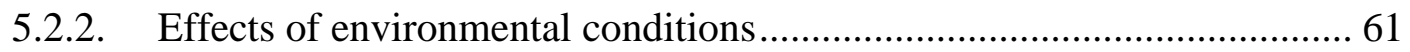

5.2.3. Effects of tillage and liming on gross $\mathrm{N}$ mineralization rates .................. 64

5.2.4. Effects of tillage and liming on NH4+ consumption............................. 65

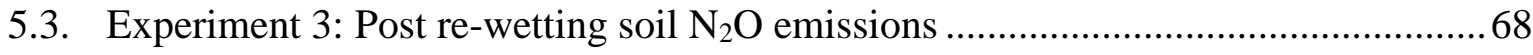

5.3.1. Effects of soil conditioning and agronomic practices on $\mathrm{N}_{2} \mathrm{O}$ emissions 68

5.3.2. Microbial communities and their effect on $\mathrm{N}_{2} \mathrm{O}$ emissions 70

5.4. Experiment 4: Effects of NT and liming on carbon and nitrogen mineralization...... 74

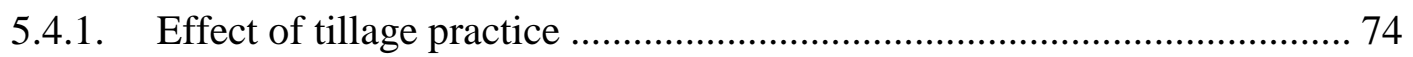

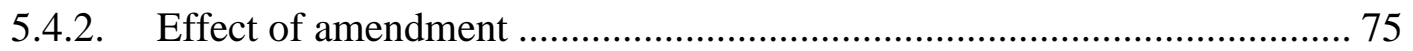

5.4.3. SEM to explain the direct and indirect effects on $\mathrm{C}$ and $\mathrm{N}$ mineralization 76 
5.5. Experiment 5: Effect of NT, liming and depth on soil proteases

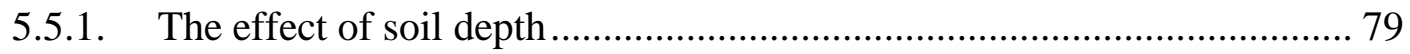

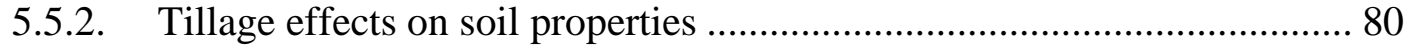

5.5.3. Soil $\mathrm{pH}$ as the key factor shaping $\mathrm{N}$ transformations ........................... 81

5.6. Experiment 6: Effect of NT and liming on plant mycorrhization .............................84

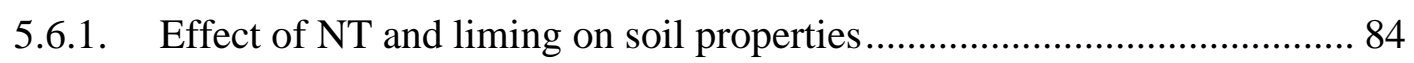

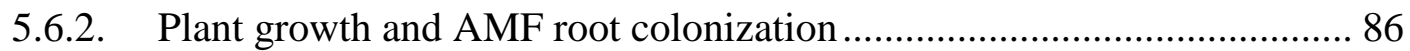

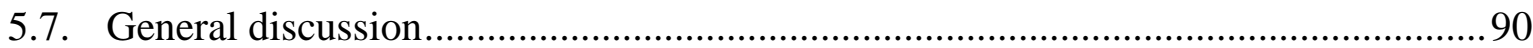

5.7.1. Were the hypothesis accurated and the result consistent through the

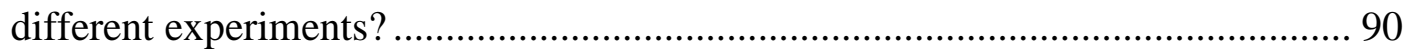

5.7.2. Which are the main implications of the obtained results?...................... 95

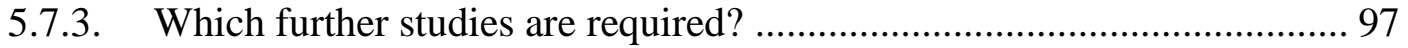

6. CONCLUSIONS ................................................................................................................ 134

6.1. Experiment 1: Seasonal variation of enzymatic and microbial activity ................... 134

6.2. Experiment 2: Gross $\mathrm{N}$ transformation rates during summer fallow ........................135

6.3. Experiment 3: Post re-wetting soil $\mathrm{N}_{2} \mathrm{O}$ emissions ............................................... 135

6.4. Experiment 4: Effects of NT and liming on carbon and nitrogen mineralization.... 136

6.5. Experiment 5: Effect of NT, liming and depth on soil proteases ............................. 136

6.6. Experiment 6: Effect of NT and liming on plant mycorrhization ........................... 137

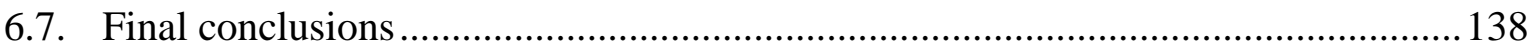

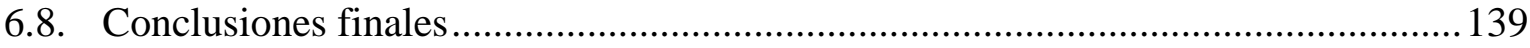

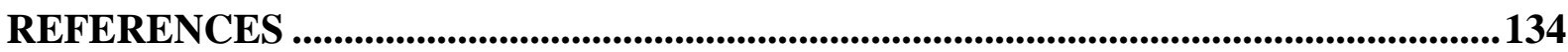

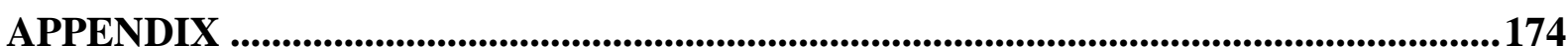




\section{INTRODUCTION}

\subsection{Soil degradation and agriculture in the Mediterranean region}

The Mediterranean climate can be considered as a transition stage between temperate and dry-subtropical climate. The main feature is a strong seasonality with a hot and dry summer and a mild and wet winter. Furthermore, the temporal distribution of rainfall is highly variable; in some areas could be concentrated in only few days of torrential rains. In view of climate change, models suggests an increase in summer temperatures, a decrease in precipitations and more frequent and intense hot waves, probably contributing to increasing aridity of the region (Giorgi and Lionello 2008).

Areas with predominant Mediterranean climate are present on all continents except Antarctica, although the largest area is the basin of the Mediterranean sea covering the south of Europe, the north of Africa and the Near East of Asia. The agriculture in the Mediterranean region started approximately 5000 years ago, and the long-term human intervention has had an enormous effect on the landscape reducing the forested area and driving stronger soil erosion compared to other areas under comparable climate (Yaalon 1997). The agricultural intensification during the 20th century and the multiple land use changes derived from the growing human pressure in the region had led to further soil degradation and reduction of soil fertility, which was reflected in the drop of agricultural yields and environmental quality (Zalidis et al. 2002; Serra et al. 2008). The substitution of natural vegetation by crops, together with unsuitable agronomic practices (such as for example excessive tillage and the excessive use of inorganic fertilizer and pesticides, monocropping or the use of low quality water for irrigation) had decreased drastically the soil quality and reduced the soil carbon (C) stored in the Mediterranean region (Zalidis et al. 2002). Although similar problems have been detected worldwide (Lal 2004; Eaton et al. 2008), soil degradation and erosion and the further loss of SOC in the Mediterranean region has been particularly exacerbated due to specific features in the Mediterranean region, including the scarcity of precipitation and the low initial soil organic carbon (SOC) content (Zalidis et al. 2002; Muñoz-Rojas et al. 2015)

The stored $\mathrm{C}$ in soil is the largest $\mathrm{C}$ stock in the terrestrial ecosystems and plays a key role in the soil functionality and C cycle (Lal 2004). Agricultural practices can affect positively or negatively to the soil $\mathrm{C}$ stocks depending on the management 
choices (Franzluebbers 2010); thus, the soil may become a significant source of C into the atmosphere if improperly managed. The magnitude of the SOC stock highlights the soils' role in the climate change, as small changes in the SOC stocks can largely affect the $\mathrm{CO}_{2}$ stored in the atmosphere (Lal 2016). The high sink capacity of soils offers a potentially useful tool to mitigate the climate change (Lal 2016). Furthermore, the SOC plays a key role in the majority of soil biogeochemical processes, affecting soil chemical, physical and biological properties, and has been thus proposed as an indicator of soil quality due to the integration of multiple soil functions (Franzluebbers 2002; Lal 2004). Therefore, the increase of SOC is crucial for mitigation and adaptation to climate change while enhancing soil chemical, physical and biological functionality (Lal et al. 2011).

In comparison with other regions of the world, the SOC of the Mediterranean soils is low (Jones et al. 2005), specially the agricultural soils which are SOC depleted respect to the natural soils (Romanyà and Rovira 2011). The scarcity of rainfall and severe summer droughts promote lowe plant biomass production than in temperate areas which reduces the $\mathrm{C}$ inputs to soils (Aguilera et al. 2013). Furthermore, the excessive tillage during the last decades has caused a decrease of the SOC stock and the emission of $\mathrm{C}$ to the atmosphere in form of $\mathrm{CO}_{2}$ (Carbonell-Bojollo et al. 2011; Romanyà and Rovira 2011). The soil disturbance by tillage breaks soil macroaggregates which leads to increased access of soil microorganisms to the $\mathrm{C}$ occluded in aggregates and micropores and increases the soil aeration, which enhances the SOC mineralization and $\mathrm{CO}_{2}$ release (Six et al. 2000; Conant et al. 2007; Carbonell-Bojollo et al. 2011). In addition, the incorporation of straw and stubble into the soil by tillage lead to a faster organic matter decomposition, which reduce the amount of $\mathrm{C}$ stabilized in soils (Chatterjee and Lal 2009).

Besides SOC depletion, tillage has several other negative impacts on soil, such as decreasing water infiltration rate and reduced water availability (Bescansa et al. 2006; Cantero-Martínez et al. 2007; Gómez-Paccard et al. 2015). In addition, tillage prolongs the periods of bare soil which are linked with higher erosion rates in sloppy areas, a common problem in Mediterranean areas (Novara et al. 2011; Keesstra et al. 2016; Sastre et al. 2017). Furthermore, tillage has been found to reduce the abundance and activity of soil earthworms (Castellanos-Navarrete et al. 2012; Crittenden et al. 2014) which play a key role in soil structure, SOC stabilization and soil organic matter (SOM) 
mineralization (Pulleman et al. 2005; Brussaard et al. 2007). Moreover, the loss of SOC caused by tillage has been found to reduce the soil microbial activity and biomass (Madejón et al. 2007, 2009; Martín-Lammerding et al. 2015).

Mediterranean soils are also negatively affected by the excessive use of inorganic fertilizers which have negative impacts in soils and environment. Specifically, soil acidification caused by an excessive use of nitrogen $(\mathrm{N})$ fertilizers is one of the main concerns in many areas in the world (Guo et al. 2010). Although the severity of soil acidification is less relevant in the Mediterranean region compared to other parts of the world due to the limestone or marls parent material (Zalidis et al. 2002), in some regions of the west of Iberian Peninsula acidity is of a great concern recently as it has been exacerbated by SOC depletion (Peregrina et al. 2008; Mariscal-Sancho et al. 2009). Overall, soil degradation is the key cause of decreasing agronomic yields, which linked with socioeconomical changes, have promoted the abandonments of extensive cropland areas (Romero-Díaz et al. 2017). Conservation agriculture has been proposed to reduce the soil degradation process or even to restore the soil quality of already degraded soils. According to FAO and adapted by Kassam et al. (2012), the three main principles of conservation agriculture are:

-Minimum soil disturbance by agronomic practices: Soil disturbance must be avoided or limited to minimum which should be achieved by the adoption of notillage (NT) or minimum tillage agriculture together with direct seeding.

-Permanent soil organic cover: Mulching with stubbles from crops or living cover crops should be used to avoid bare soil periods.

-Crops diversification: Rotations of annual crops or the use of intercropping and cover crops in perennial systems is advised. Legumes should be included due to their positive effect on nitrogenous plant nutrition.

Due to the large-scale of soil degradation and the advancing deleterious impacts of climate change on agro-ecosystems under Mediterranean climate, one of the objectives of the present thesis was the evaluation of the suitability of NT to restore degraded soils in SW Spain with special emphasis on soil microbiological indicators. 


\subsection{No-tillage agriculture under Mediterranean climate}

No tillage is of high interest in annual arable croplands as it contributes to minimum soil disturbance and increases soil organic cover, well in line with the principles of conservation agriculture. No-tillage is defined as planting crops in soil which has not been previously prepared by tillage with at least $30 \%$ of crop residues remaining on the field in the form of mulch (Triplett and Dick 2008).

During centuries, soil tillage has been considered to be essential for the weed control and soilbed preparation. Hence, soil tillage increased the food production because of a stimulation of SOM mineralization which increases the availability of nutrients (Triplett and Dick 2008). However, after several years of cropping, the stimulation of SOM mineralization causes a nutrient depletion in soils, a reduction of crop yields, high soil erosion risks and the consequent abandonment of cropland which were naturally revegetated by pastures, shrublands and forests (Triplett and Dick 2008). This was specially evident during the paradigmatic episode of the so-called "Dust Bowl" during the 1930s in the steppe of central-west USA, in which vegetation clearance and deep tillage of large fields caused strong soil erosion during a severe drought period with dramatic environmental and economical consequences (Montgomery 2012).

Given the evidence of soil degradation caused by tillage and the development of herbicides, during the 1960s, the first attempts of NT agriculture were made in the corn fields of USA. Nevertheless, it was not until 1990s when the implementation of NT was extended globally with South America or Australia as the most important regions of NT after USA (Triplett and Dick 2008). On the other hand, the use of NT in Europe and Asia was remained rather low compared to America and Australia, probably because of the small size of the farms and the long tradition of tillage practices. In China, despite initially slower adoption rates great government efforts during the last decade have been largely promoted the adoption of NT practices (He et al. 2010). In the case of the Mediterranean Europe, the adoption of NT is increasing in the last two decades, especially in Spain, Italy and France (Kassam et al. 2012). However, several criticism associated with the increase of weeds and plant diseases, the dependency on the herbicides or the machinery cost are delaying a larger implementation of NT (Kassam et al. 2012). 
Besides being an important tool to combat soil erosion, one of the main benefits of NT is the increase of SOC stocks (West and Post 2002; Franzluebbers 2010) which has highlighted the NT agriculture as a strategic tool to increase the $\mathrm{C}$ storage in soil aiming to mitigate the climate change (Lal 2016). The reduction of soil disturbance is linked with reduced soil aeration and aggregate disruption, which is of a special interest because soil aggregates store large amounts of SOC which are protected from microbial decomposition (Six et al. 2000; Conant et al. 2007; Carbonell-Bojollo et al. 2011). In addition, the higher expected yields and biomass production can increase the crop residues, which, together with the no stubble soil incorporation, slow down the organic matter mineralization and increase the amount of stabilized $\mathrm{C}$ in the soil (Chatterjee and Lal 2009; Plaza-Bonilla et al. 2014). In a meta-analysis focusing on NT in Spain, González-Sánchez et al. (2012) calculated an increase rate of stocks of $0.85 \mathrm{Mg} \mathrm{C} \mathrm{ha}^{-1}$ year $^{-1}$ in the first ten years after NT implementation, although in longer periods the C accumulation is expected to be lower until it reaches the maximum $\mathrm{C}$ accumulation. Due to the limitation of soil mixing, NT leads to the stratification of SOC along the soil profile, with higher SOC in the topsoil than in deeper layers (Franzluebbers 2002), similarly as in natural systems.

Reduction of soil tillage often leads to the improvement of soil structure, in particular soil aggregation. The reduction of soil disturbance by tillage reduces the mechanical breakdown of macroaggregates (Six et al. 2000), which in turn stimulates the formation of microaggregates (inside the macroaggregates) in which the SOC is stabilized and protected from mineralization (Six et al. 2000). The stabilization of SOC within relatively stable soil microaggregates is one of the key mechanisms of SOC accumulation under NT. In addition, by reducing tillage, the fragile fungal mycelia do not break, which is also related with aggregate stabilization by soil fungi (Beare et al. 1997; Rillig 2004).

Other positive aspect of NT is the maintenance of soil biopores and root channels (macropores) which are the responsible for better water drainage and higher infiltration rates (Kay and VandenBygaart 2002). This phenomena is also stimulated by the higher abundance of earthworms in NT (Castellanos-Navarrete et al. 2012; Crittenden et al. 2014). The higher abundance of macropores, together with the soil surface protected by stubble, increase the water infiltration to deeper soil layers and reduce the water runoff. In addition, the mulching effect of crop residues in soil surface can reduce the water 
evaporation especially under drought conditions (Vita et al., 2007). Both improved infiltration and reduced evaporation, increase water availability for crops, which is one of the main drivers of higher crop production with NT under Mediterranean or semiarid conditions (Bescansa et al. 2006; Cantero-Martínez et al. 2007; Vita 2016; BrunelSaldias et al. 2018; Hontoria et al. 2018). Under Mediterranean climate, where the rainfall is scarce and unevently distributed, and the period with higher sunlight radiation is delayed respect to the rainfall season, NT provides higher available soil water in rainfed agriculture increasing the crop yields (Cantero-Martínez et al. 2007). Furthermore, the increase of water infiltration through the net of soil macropores could reduce the waterlogging conditions, especially in soils with abrupt textural changes in sub-superficial layers (Acrisol, Luvisol, etc.) enhancing the crop yields in years with excess of rainfall during winter (Gómez-Paccard et al. 2015). The positive effect of NT under both dry and wet periods (higher water use efficiency and reduced waterlogging, respectively) could help to mitigate the impacts of climate change in Mediterranean areas where the projection predicts a reduction of precipitation, longer drought periods and an increase in extreme rainfall events (Varela-Ortega et al. 2016).

Probably drived by the higher accumulation of SOC, NT practices have been found to increase soil microbial biomass and microbial activity in the topsoil (Alvear et al. 2005; Roldán et al. 2005; Madejón et al. 2007, 2009; Martín-Lammerding et al. 2015). In addition, soil cover by crop residues ameliorates the temperature fluctuation of soil (Fabrizzi et al. 2005; Dahiya et al. 2007), which, together with higher soil moisture content, ameliorate the drought stress and increase the soil microbial resilience to disturbance (Hueso et al. 2011). Soil microorganisms play a key role in soil functioning as they affect SOM mineralization and the nutrient cycling, and, in general terms, higher soil microbial biomass is considered a positive indicator of adequate soil functioning (Gonzalez-Quiñones et al. 2011). For example, higher microbial biomass and higher microbial activity in NT can affect positively the $\mathrm{N}$ cycle in soil: On one hand, by increasing the SOM mineralization and providing inorganic $\mathrm{N}$ for plant uptake (Halpern et al. 2010), and on the other hand, by increasing the $\mathrm{N}$ immobilization and reducing the risk of $\mathrm{N}$ losses (Booth et al. 2005). Finally, the absence of soil disturbance prevents the disruption of the mycelia network of arbuscular mycorrhizal fungi (AMF) which form a symbiosis with majority of crops enhancing the nutrient uptake or water supply to plants (Borie et al. 2006; Dai et al. 2015; Wang et al. 2016). 
At global scale, the effects of NT on crop yields are variable depending on many factors including climate, fertilization regime, crop type or irrigation schemes (Pittelkow et al. 2015). The most positive effects on yields were obtained when rainfed crops were grown in semi-arid and arid climates, which highlights the suitability of NT for Mediterranean conditions. In addition, the reduction of labor and fuel consumption reduce the production cost and reduce the $\mathrm{CO}_{2}$ emission derived from machinery (Sharma et al. 2011; Šarauskis et al. 2014).

The adoption of NT is increasing in the last years in Spain, probably triggered by the observed positive effects. In the period 2009-2013, the areas managed by NT grew by $208 \%$, while the groundcovers in perennial crops (other recommended practice by conservation agriculture) was increased by $54 \%$ in the $2006-2013$ period (GonzalezSanchez et al. 2015). This increase was supported partially by the efforts of the local governments through the Rural Development Programs which provided funding over $€$ 200 million in the 2000-2006 period (Gonzalez-Sanchez et al. 2015). However, there is still a high potential of NT surface area increase as the area recently managed as NT only accounts for $7.5 \%$ of total arable crops (Gonzalez-Sanchez et al. 2015). Therefore, more efforts by the public institutions are required to maintain the positive trend in NT adoption.

\subsection{Liming to restore acid soils}

Acid soils occupy approximately a $30 \%$ of ice-free world surface and are concentrated mainly in two different areas in form of belts: one in the north humid temperate region covered by coniferous forests, and other in the humid tropics which is naturally covered by savannah or tropical rainforest (von Uexküll and Mutert 1995). According to FAO soil classification, the most extended type of acid soils are Acrisol, Ferralsol (typical from humid tropics), Podzol and Gleysol (from north humid temperate region) (von Uexküll and Mutert 1995). In the Mediterranean region, the presence of acid soils is limited because of the dominance of limestone, dolomites or marls as parent materials which have developed neutral or alkaline soils (Yaalon 1997). Nevertheless, the $40 \%$ of the Iberian Peninsula is covered by acid soils, mainly in the north and west area (Viadé 2005).

The soils are naturally acidified by weathering and leaching of cations from soil solution and exchange complex, which are substituted by protons (Fageria and Baligar 2008). Therefore, acid soils are generally formed under climates with higher 
precipitation than evapotranspiration which promotes leaching. When the acidification reaches soil $\mathrm{pH}$ bellow 5.5, the high $\mathrm{H}^{+}$concentration causes the protonation of the clay surfaces and the liberation of exchangeable aluminum $\left(\mathrm{Al}^{3+}\right)$ to the exchange complex (Meriño-Gergichevich et al. 2010). This causes the $\mathrm{Al}^{3+}$ toxicity, which inhibits appropriate root development and limits the nutrient and water uptake by crops. The $\mathrm{Al}^{3+}$ toxicity is the main responsible factor of the poor fertility of acid soils, followed by manganese toxicity and deficiency of available calcium $(\mathrm{Ca})$, magnesium $(\mathrm{Mg})$ and phosphorus (P) (von Uexküll and Mutert 1995). In addition, very acidic soils cause low microbial activity and limited SOM mineralization (Acosta-Martínez and Tabatabai 2000; Corre et al. 2003; León et al. 2017)

In the last decades, the agricultural soils have been strongly acidified by unsuitable agronomic practices (Guo et al. 2010). The excessive use of inorganic $\mathrm{N}$ fertilizer in form of ammonium $\left(\mathrm{NH}_{4}^{+}\right)$or urea, the leguminous crops and the cation uptake by crops followed by nutrient removal in the harvest, are the main drivers of soil acidification in croplands (Guo et al. 2010; Goulding 2016). In addition, the reduction of SOM content by unsuitable agronomic practices often leads to soil acidification and releases of toxic amounts of $\mathrm{Al}^{3+}$ previously bound in organo-mineral complexes (Godsey et al. 2010; Guo et al. 2010).

In order to revert the excessive acidification of acid soils and enhance soil fertility and crop yields, the application of liming materials such as limestone, dolomite, gypsum or phosphogypsum, is a widespread technique (Goulding 2016). In addition, recent studies have evaluated the feasibility of biochar as liming material (Yuan and $\mathrm{Xu} 2011$; Teutscherova et al. 2017a) or sugar beet foam, a by-product of sugar purification which is also rich in some other nutrients (Goulding 2016; León et al. 2017). Lime materials provide $\mathrm{Ca}^{2+}$ and anions $\left(\mathrm{OH}^{-}\right)$which neutralize soil acidity, raise the soil $\mathrm{pH}$ and displace the $\mathrm{Al}^{3+}$ from the exchange complex (Fageria and Baligar 2008) ameliorating the $\mathrm{Al}^{3+}$ toxicity, supplying cations $(\mathrm{Ca}$ and $\mathrm{Mg}$ ) and increasing the availability of $\mathrm{P}$ to crops (Fageria and Baligar 2008; Meriño-Gergichevich et al. 2010)

The main benefits of liming are the increase of crop yields and the increase of the $\mathrm{N}$ or P uptake by plants (Borie and Rubio 1999; Goulding 2016; Tiritan et al. 2016; Liao et al. 2018). In addition, lime application supplies large amounts of $\mathrm{Ca}^{2+}$ which increases the soil aggregation and the enhances soil water infiltration in the medium term, although in short-term the $\mathrm{pH}$ raise can disperse clay colloids (Haynes and Naidu 
1998; Goulding 2016). Furthermore, the soil acidity alleviation stimulates SOM mineralization (Acosta-Martínez and Tabatabai 2000; León et al. 2017) which may have two different effects: firstly, SOC depletion (Paradelo et al. 2015), and, secondly, increase the availability of mineral $\mathrm{N}$, which may in turn eitherincrease the plant $\mathrm{N}$ uptake or lead to higher $\mathrm{N}$ losses (Teutscherova et al. 2017a, 2018; Liao et al. 2018). Nevertheless, due to the large number of factors influencing SOM decomposition in agro-ecosystems, no general rule can be drawn on the effect of liming with regard to SOM cycling (Paradelo et al. 2015; Aye et al. 2016; Grover et al. 2017).

Liming has been also proposed as a strategy to mitigate the $\mathrm{N}_{2} \mathrm{O}$ emission under semiarid conditions (Barton et al. 2013a). In areas where the summer fallow is unavoidable due to severe drought and extreme temperatures, soil rewetting by the first autumn rains promotes the highest $\mathrm{N}_{2} \mathrm{O}$ peaks of the season (Barton et al. 2008, 2011). Liming application to acid soil have been found to reduce those $\mathrm{N}_{2} \mathrm{O}$ peaks by of the alteration of the microbial communities and the efficiency of the nitrification and denitrification process (Barton et al. 2013a). However, liming causes an initial increase of the $\mathrm{CO}_{2}$ emission during lime neutralization in the acid soils, therefore more efforts are required to evaluate the complex relationships between liming application and greenhouse gasses emission (Gibbons et al. 2014; Goulding 2016).

\subsection{The combination of no-tillage and liming}

Given the benefits of both NT agriculture and liming, the combination of both techniques has been proposed as a strategy to restore acid degraded soils. This combination has been studied mainly in tropical and subtropical areas such Brazil, where the decades of unsuitable soybean monocropping and overgrazing have caused a critical SOM depletion, further soil acidification of initially acid soils and soil physical properties degradation (Caires et al. 2005, 2006; Batlle-bayer et al. 2010; Joris et al. 2016; Tiritan et al. 2016; Carmeis Filho et al. 2017). The main objective of liming is the raise of soil $\mathrm{pH}$ and the alleviation the $\mathrm{Al}^{3+}$ toxicity, while the purpose of $\mathrm{NT}$ is to increase SOC stocks and to enhance soil physical properties (Caires et al. 2006). When both practices are combined, the liming amendments are spread over soil surface instead of the incorporation into the soil by tillage. According to Joris et al. (2016), the main advantages of superficial lime application respect to liming incorporation by tillage are:

- The liming incorporation by tillage increase the SOM mineralization, which linked with liming could cause SOC depletion. With surface liming, this risk of 
SOC depletion can be reduced due to reduced soil aggregate disruption and tillage-induced aeration.

- The costs and time consumption of lime incorporation by tillage are reduced

- The positive effect of NT in soil physical properties is increased by the action of lime which supply cations as $\mathrm{Ca}^{2+}$ or $\mathrm{Mg}^{2+}$ which favor aggregate formation.

-The farmers benefit from the increased crop yields resulting from both NT and liming.

On the other hand, due to low mobility of several liming materials $\left(\mathrm{CaCO}_{3}\right)$ within the soil profile, there is a concern about the effectively of surface liming application to neutralize the soil acidity in deeper soil layers (Conyers et al. 2003). However, recent studies have found no differences between the method of liming application, probably because the enhancement of soil structure in NT which increase the water infiltration and the downward movement of lime to deeper soil layer (Caires et al. 2011; Tiritan et al. 2016; Auler et al. 2017). Therefore, the combination of NT and liming is a probably a valid strategy to restore degraded soil and to enhance the crop yields while reducing the operational costs and environmental impacts.

\subsection{No-tillage and liming to restore Raña soils}

The Acrisols of the rañas surface in the west of Iberian Peninsula are a particular case of acid soil in Mediterranean region. The rañas are flat detritic formations from middle-Pliocene formed near the quartzitic ranges which cover more than $10^{6}$ ha (Espejo Serrano 1985; Espejo 1987; Peregrina et al. 2008). Rañas are characterized by highly weathered soils with low $\mathrm{pH}$ and the exchange complex saturated by $\mathrm{Al}^{3+}$. In addition, unsuitable agronomic practices during the $20^{\text {th }}$ century caused a dramatic reduction of SOM and deterioration of soil physical properties (Mariscal et al. 2007). To restore these degraded soils, an experimental field station was started in 2005, in which liming and NT were combined. The NT, as an alternative to traditional tillage (TT) and liming application were combined in a full factorial design: NT (no-tillage without liming amendment), TT (traditional tillage without liming amendment), NT-A (notillage with liming amendment), and TT-A (traditional tillage with liming amendment).

Prior studies to the present thesis have shown that the combination of NT and liming ameliorates soil acidity and $\mathrm{Al}^{3+}$ toxicity (Gómez-Paccard et al. 2013), reduces 
the waterlogging periods and increases soil moisture during the periods of high evapotranspiration (Gómez-Paccard et al. 2015). Furthermore, both practices combined increase soil aggregation and the $\mathrm{C}$ and $\mathrm{N}$ contents of the aggregates (Hontoria et al. 2016) while increasing the crop yields of a forage mixed crop of oat and vetch (Hontoria et al. 2018). As a continuation of the previous work, this study aims at addressing the missing gaps in our understanding of synergistic impact of both techniques on soil microbial activity and nutrient transformations and the underlying mechanisms. In particular, this thesis at the evaluation of the effect of the combined use of NT and liming on (i) soil biological properties under the seasonality of the Mediterranean climate, (ii) the soil $\mathrm{N}$ transformation processes during the summer fallow period and (iii) the subsequent rewetting event; (iv) isoil $\mathrm{C}$ and $\mathrm{N}$ mineralization, (v) soil protease activity and $\mathrm{N}$ availability and (vi) the impact on AMF-plant interaction and nutrient uptake patterns.

\subsection{Seasonal variation of microbial activity as affected by tillage practice and liming under Mediterranean climate.}

Although the effects of both NT and liming on soil microbiology have been largely reported individually (Inagaki et al., 2016; Madejón et al., 2009; Mijangos et al, 2010; Martín-Lammerding et al., 2015; Tabatabai, 2000), less attention has been paid to the combination and interactions between both agronomic techniques. Generally, the accumulation of bulk SOM and labile fractions of C caused by the NT increases the enzyme activity (EA) and the microbial biomass of the Mediterranean soils (Madejón et al. 2009). Moreover, the liming application to acid soils and the subsequent $\mathrm{pH}$ raise have shown to increase the activity of involved most of the enzymes in the C, N, P and sulfur (S) cycle (Acosta-Martínez and Tabatabai 2000). However, in the few studies where both treatments were combined, their potential interaction in the soil microbiology was only partially investigated and did not show any clear pattern (Ekenler and Tabatabai 2003; León et al. 2017).

A better understanding of the possible interactions between both practices and their effect on soil biological activity should be considered as fundamental in view of global change. More intense, frequent and longer droughts together with heat waves may occur in the future in south-western Spain (Varela-Ortega et al., 2016), which could affect the microbial biomass and soil EA involved in the $\mathrm{C}, \mathrm{N}$ or $\mathrm{P}$ cycling (Sardans et al. 2008; Bérard et al. 2011; Acosta-Martínez et al. 2014). Furthermore, 
ecosystem responses to heat waves and drought will depend on soil management history (Hou et al. 2016). Many studies have shown the positive effect of NT on soil moisture in semiarid conditions, allowing for higher soil water contents during dry periods (Bescansa et al., 2006; De Vita, 2007). In the same line, the NT promotes the accumulation of crop residues on the soil surface which reduces soil temperature during the summer months (Dahiya et al. 2007). This amelioration of the extreme conditions could reduce the stress of soil microorganisms and lead to higher EA during the summer periods. Moreover, the expected increase of the EA caused by liming may lead to a multiplicative effect of NT on EA and alteration of the SOM dynamics and biogeochemical cycles.

\subsection{The interactive effect of $\mathrm{NT}$ and liming on gross $\mathrm{N}$ transformations rates during the summer fallow}

Extensive areas under Mediterranean climate are characterized by soils with low productivity and SOC levels. The strongly seasonal precipitation pattern usually results in a severe drought period during the summer, which requires several months of fallow period between two consecutive growing seasons. In the absence of living plants, ammonium $\left(\mathrm{NH}_{4}^{+}\right)$is mainly subjected to two microbial processes: nitrification to nitrate $\left(\mathrm{NO}_{3}{ }^{-}\right)$and microbial immobilization. Thus, the $\mathrm{NH}_{4}{ }^{+}$consumption includes both nitrification and $\mathrm{NH}_{4}{ }^{+}$immobilization. The $\mathrm{NH}_{4}{ }^{+}$immobilization during this period can be beneficial from both the environmental and the agronomic point of view as microbial biomass may operate as a temporal storage until the microbial dieback, when $\mathrm{N}$ and other nutrients are released and become available again to the plants (Kuzyakov and Xu 2013). On the contrary, the accumulation of $\mathrm{NO}_{3}^{-}$during the fallow period may negatively impact the $\mathrm{N}$ balance with possible implications for $\mathrm{N}$ losses (Barton et al. 2008, 2011; Sanchez-Martin et al. 2010; Sanz-Cobena et al. 2017). Previous studies have found strong influence of drought and soil temperature in the gross $\mathrm{N}$ transformations and microbial communities under semiarid conditions (Cookson et al. 2006; Bérard et al. 2011; Hueso et al. 2012). Higher temperatures and low soil moisture can affect the $\mathrm{N}$ cycle leading to a significant accumulation of inorganic $\mathrm{N}$ (Luxhøi et al. 2008b; Schaeffer et al. 2017), particularly in the form of $\mathrm{NH}_{4}{ }^{+}$, as gross nitrification has been found to be more sensitive to drought than gross mineralization (Cheng et al. 2014). In addition, an accumulation of dissolved organic carbon and N (DOC and DON) is expected as a consequence of drought (Schaeffer et al. 2017). Therefore, the 
understanding of soil $\mathrm{N}$ transformations during drought seems to be crucial for the approapriate assessment of the $\mathrm{N}$ balance in Mediterranean agro-systems.

In Mediterranean areas, the role of NT in soil physical properties restoration, SOC accumulation and soil moisture maintenance seems to be crucial during the water deficient periods (Kassam et al. 2012). Thus, the combination of higher soil moisture under NT during the dry Mediterranean summer along with the higher availability of C, can in turn positively affects soil microbiological processes. Higher $\mathrm{C}$ mineralization rates and enzymatic activities have been reported under NT (Madejón et al. 2009), which may lead to increased accumulation of mineral N. Alternatively, the higher contents of labile $\mathrm{C}$ can enhance the microbial $\mathrm{N}$ immobilization (Booth et al. 2005; Fisk et al. 2015a), decreasing the mineral N pool in the soil. Additionally, recent studies have demonstrated that, compared to TT, the NT practices can enhance the abundance of ammonia-oxidizing populations, which are responsible for oxidation of $\mathrm{NH}_{4}{ }^{+}$to $\mathrm{NO}_{3}{ }^{-}$ (Li et al. 2015; Munroe et al. 2016; Segal et al. 2017). The seemingly contrasting results highlight the serious gap in our understanding of all NT impacts on N cycling under Mediterranean climate with serious implications for $\mathrm{N}$ balance predictions and optimization of the agronomic techniques.

Liming may also have a strong impact on soil $\mathrm{N}$ cycling. The alleviation of soil acidity can enhance the $\mathrm{N}$ mineralization by increasing the activity of the soil enzymes involved in the $\mathrm{N}$ cycle (León et al. 2017; Teutscherova et al. 2017a) and can increase the nitrification rates (Feng et al. 2003) by affecting the ammonia-oxidizing populations (Banning et al. 2015), which are very sensitive to changes of soil $\mathrm{pH}$ (Rousk et al. 2010). The two major groups of ammonia-oxidizers, ammonia-oxidizing bacteria (AOB) and ammonia-oxidizing archaea (AOA), differ in their abundance and activity according to soil properties and agricultural practices (Nicol et al. 2008; Pereira e Silva et al. 2012). Several studies have demonstrated that AOA and AOB prefer different soil niches depending on soil $\mathrm{pH}$ and the $\mathrm{NH}_{4}{ }^{+}$supply: while AOA may be of higher importance under harsher environments (e.g. low substrate supply, acidic $\mathrm{pH}$ and anaerobic conditions (Chen et al. 2011; Xu et al. 2012; Stewart et al. 2012; Qin et al. 2013)), AOB may be active in more fertile soils which are richer in $\mathrm{NH}_{4}{ }^{+}$(Di et al. 2010). Despite attempts to clarify the effect of $\mathrm{pH}$ changes on $\mathrm{N}$ transformations, the interactive effect of NT and liming remains unaddressed. 
Soil microbial activity and SOC mineralization rates have been found to be considerably higher during the summer in the NT plots compared to TT (Vazquez et al. 2017), which suggest higher mineralization rates and a subsequent increase of soil mineral N under NT. The alleviation of soil acidity through liming may further enhance $\mathrm{N}$ transformation rates (Teutscherova et al. 2017a); thus, a critical accumulation of $\mathrm{NO}_{3}{ }^{-}$ during the fallow period may be expected. To our knowledge, no studies have focused on the combined effects of NT and liming on soil gross N transformations.

\subsection{Impact of $\mathrm{NT}$ and liming in $\mathrm{N}_{2} \mathrm{O}$ emissions after soil rewetting}

The summer period in Mediterranean regions is characterized by long periods of drought, and due to climate change heat waves are expected to become more extreme and extended in time in the near future (IPCC, 2014; Varela-Ortega et al., 2016). As these periods are unsuitable for plant growth without irrigation, many winter crop varieties are used, which are sown in autumn after the first rains and harvested in the spring, leaving the summer period uncultivated (Álvaro-Fuentes et al. 2009). During this fallow period, the low soil moisture and high soil temperatures affect the $\mathrm{C}$ and $\mathrm{N}$ cycles, reduce the soil microbial activity, and promote the accumulation of partially decomposed organic matter (Borken and Matzner 2009). This phenomenon is critical in the case of the inorganic $\mathrm{N}$, which tends to accumulate in form of $\mathrm{NO}_{3}{ }^{-}$or $\mathrm{NH}_{4}{ }^{+}$in the absence of plant uptake (Barton et al. 2011; Parker and Schimel 2011; Schaeffer et al. 2017). Such accumulation of inorganic $N$ can cause substantial $N$ losses after episodic rainfall events (Barton et al. 2011; Parker and Schimel 2011; Schaeffer et al. 2017). In addition, the understanding of the importance of substrate accumulation during drought and its impact on nutrient transformations after rewetting would help to optimize irrigation practices in order to mitigate the $\mathrm{N}_{2} \mathrm{O}$ emissions derived from irrigated fields under Mediterranean conditions (Sanz-Cobena et al. 2017; Deng et al. 2018).

Soil rewetting after a prolonged drought period triggers the release of $\mathrm{CO}_{2}$ and $\mathrm{N}_{2} \mathrm{O}$ pulses in a short period of time due to a cascade of soil reactions. Rapid osmotic changes following rewetting induce the lysis of microbial cells while promoting the consumption of accumulated substrates determining high $\mathrm{CO}_{2}$ fluxes (Borken and Matzner 2009). Soil rewetting increases diffusion and hydrological connectivity of $\mathrm{N}$ compounds in soil, reactivating the $\mathrm{N}$ mineralization and nitrification rates and related gas fluxes (Manzoni et al. 2014; Schaeffer et al. 2017). Furthermore, the rapid stimulation of soil $\mathrm{C}$ mineralization often leads to a depletion of soil $\mathrm{O}_{2}$ and the 
formation of anoxic hotspots where denitrification of accumulated $\mathrm{NO}_{3}{ }^{-}$can occur (Barton et al. 2013a; Leitner et al. 2017). Both nitrification and denitrification processes during the soil rewetting can cause $\mathrm{N}_{2} \mathrm{O}$ emissions, and have been identified as the main contribution to $\mathrm{N}_{2} \mathrm{O}$ losses in the semiarid rainfed agriculture (Barton et al. 2011, 2013b).

Liming of acid soils has been proposed as a strategy to mitigate the $\mathrm{N}_{2} \mathrm{O}$ emissions after soil rewetting by rainfall after prolonged drought (Barton et al. 2013b, a). Low soil $\mathrm{pH}$ value has a critical impact on the size and community structure of the nitrifier and denitrifier populations, and also affecting their transcriptomic activity (Nicol et al. 2008; Liu et al. 2010; Brenzinger et al. 2015; Li et al. 2018). Therefore, the neutralization of soil $\mathrm{pH}$ by liming often stimulated the nitrification process by changing the AOA and AOB relative abundanceand/or activity (Nicol et al. 2008; Teutscherova et al. 2017a). Furthermore, at the same time, neutralization reduces the nitrification-derived $\mathrm{N}_{2} \mathrm{O}$ emissions by stimuling $\mathrm{NO}_{2}{ }^{-}$oxidation to $\mathrm{NO}_{3}{ }^{-}$and reducing $\mathrm{NO}_{2}{ }^{-}$accumulation in the soil (Feng et al. 2003). Similarly, while soil pH neutralization often leads to denitrification enhancement and a reduction of $\mathrm{N}_{2} \mathrm{O}: \mathrm{N}_{2}$ ratio in the emissions as a result of the alteration of denitrifiers community composition and of the transcriptional and post-transcriptional activity of $\mathrm{N}_{2} \mathrm{O}$ reductase $\left(\mathrm{N}_{2} \mathrm{OR}\right)$ (Dandie et al. 2011; Brenzinger et al. 2015; Obia et al. 2015).

Liming has been found to decrease the $\mathrm{N}_{2} \mathrm{O}$ emission after rewetting via its effects on nitrification, as demonstrated using ${ }^{15} \mathrm{~N}$ labelling techniques (Barton et al 2013a). Nevertheless, the possible impacts of liming on the transcription of genes involved in $\mathrm{N}$ cycling has not been addressed, despite its usefulness in the elucidation of processes leading to $\mathrm{N}_{2} \mathrm{O}$ emissions and in the discrimination between nitrification and denitrification (Németh et al. 2014; Theodorakopoulos et al. 2017). Low soil pH have been found to reduce the nirK, nirS and nos $Z$ transcription and strongly control $\mathrm{N}_{2} \mathrm{O}$ emissions (Liu et al. 2010; Brenzinger et al. 2015). Similarly, increasing soil pH decreases the AOA transcription and increases the AOB transcription (Nicol et al. 2008). This transition to AOB could impact the $\mathrm{N}_{2} \mathrm{O}$ due to higher fluxes of $\mathrm{N}_{2} \mathrm{O}$ caused by AOB when compared to AOA (Hink et al. 2017). Therefore, the evaluation of key gene transcription after rewetting may shed light on the mechanisms by which soil liming affects the soil $\mathrm{N}_{2} \mathrm{O}$ emissions. 
Tillage is another factor that can have a substantial impact on greenhouse gases (GHG) emissions from agriculture, as it modifies the soil structure, water movement and the soil organic carbon (SOC) content (van Kessel et al. 2013), which are all significant factors modifying the microbial activity and gas fluxes. Under Mediterranean climate, no-tillage (NT) have been found to reduce the $\mathrm{N}_{2} \mathrm{O}$ emissions in rainfed agriculture by changing the soil-water relations and the increase of SOC (García-Marco et al. 2016; Guardia et al. 2016). However, the role of NT in $\mathrm{N}_{2} \mathrm{O}$ emissions after soil rewetting remains poorly understood. According to Harrison-Kirk et al. (2013), the $\mathrm{N}_{2} \mathrm{O}$ during the drying/wetting cycles tends to increase in soil with higher SOC content. In fact, the higher soil organic matter under NT could stimulate N mineralization process, subsequently increasing the inorganic $\mathrm{N}$ supply which is prone to nitrification (Vazquez et al. 2019). In addition, NT could lead to a higher SOC mineralization rates and increase the presence of anaerobic microsites allowing higher denitrification (Ruser et al. 2006). Nevertheless, higher SOC content could also lead to a reduction of $\mathrm{N}_{2} \mathrm{O}$ emission due to enhanced $\mathrm{N}$ immobilization as proposed by Fisk et al. (2015b). Moreover, C availability has been found to affect the transcription activity of denitrifiers and highlighted the $\mathrm{pH}$ effect on denitrification because higher $\mathrm{C}$ availability supply energy for denitrifiers and increase their transcription (Liu et al. 2010; Obia et al. 2015). Therefore, the combination of both alteration of SOC content (caused by different tillage practices) and modification of soil $\mathrm{pH}$ (by liming) may contribute to the understanding of the mechanisms involved in $\mathrm{N}_{2} \mathrm{O}$ production and/or consumption as well as to the identification of the underlying mechanisms.

\subsection{Effects of $N T$ and liming combination on soil and $C$ and $N$ mineralization}

Despite the well-described benefits and drawbacks of NT and superficial lime application, the impact of their combination on $\mathrm{C}$ and $\mathrm{N}$ mineralization are still poorly understood, as both practices (tillage and liming) affect directly and/or indirectly many soil chemical properties and biological traits involved in SOM mineralization. Notillage have been found to increase the $\mathrm{C}$ and $\mathrm{N}$ mineralization due to the overall enhancement of $\mathrm{C}$ and $\mathrm{N}$ organic pools, microbial biomass and enzymatic activity (Madejón et al. 2009; Vazquez et al. 2017). Liming of acid soils have been also found to increase the activity of enzymes related to the $\mathrm{C}$ and $\mathrm{N}$ cycling and to stimulate $\mathrm{N}$ mineralization and nitrification (Feng et al. 2003; Paradelo et al. 2015; León et al. 2017; Teutscherova et al. 2017a). However, the increase of bivalent cation as $\mathrm{Ca}$ has been 
demonstrated to enhance soil aggregation and reduce the $\mathrm{C}$ mineralization in some cases (Paradelo et al. 2015). Finally, both practices may have contradictory effect on both bacterial and fungal populations, both responsible of the mineralization processes: NT generally increases the fungi-to-bacteria ratio, F:B due to the suppressed disruption of fragile fungal hyphae usually provoked by tillage (Zhang et al. 2012), while the raise of soil $\mathrm{pH}$ promotes reductions in the $\mathrm{F}: \mathrm{B}$ ratio (Rousk et al. 2010).

The elucidation of the combined effect of NT and liming over $\mathrm{C}$ mineralization seems to be key to predict the their jointed capacity to increase the soil $\mathrm{C}$ storage and promote the role of agricultural soils as $\mathrm{C}$ sinks. On the other hand, the higher $\mathrm{N}$ mineralization and nitrification promoted by liming may either enhance the availability of $\mathrm{N}$ for crops (Liao et al. 2018) or increase the risk of $\mathrm{N}$ losses in the absence of crops (Teutscherova et al. 2018). However, a higher amount of C under NT, particularly labile $\mathrm{C}$ fractions, could promote the $\mathrm{N}$ immobilization and reduce net $\mathrm{N}$ mineralization (NNM) (Booth et al. 2005) and thus, decrease the risk of $\mathrm{N}$ losses.

In order to evaluate the complex relationships between the variables and the high correlation among the soil chemical and biological parameters involved in the mineralization of soil $\mathrm{C}$ and $\mathrm{N}$, the use of Structural Equation Models (SEM) has increased during the last years due to its usefulness to improve our understanding of the causal links among studied variables (Colman and Schimel 2013; Fanin and Bertrand 2016; Pommier et al. 2018; Qiu et al. 2018; Wade et al. 2018). In addition, although several recent studies have evaluated the impact of different tillage practices on $\mathrm{C}$ cycle and microbial activity using SEM (Zhang et al. 2013, 2018; Crittenden and de Goede 2016) with promising results, the combined effect of these two common agricultural practices has not been addressed using SEM. Therefore, the use of SEM technique could help to elucidate the direct and indirect effects of NT and liming on C and N mineralization process.

\subsection{Soil protease activity and $\mathbf{N}$ supply in different soil layers as affected by NT and liming}

The increase of the $\mathrm{N}$ use efficiency is a critical issue in the search of ways of enhancing crop yields while reducing $\mathrm{N}$ losses and therefore environmental harms in modern agriculture. To assess well-informed recommendations on the use of $\mathrm{N}$ fertilizers, a deep understanding of the factors affecting the mineralization of organic $\mathrm{N}$ is crucial (Miller and Geisseler 2018). Protein degradation is considered the rate- 
limiting step of $\mathrm{N}$ mineralization (Weintraub and Schimel 2005). Up to $40 \%$ of the total soil $\mathrm{N}$ is in proteinaceous form (Sowden et al. 1977; Schulten and Schnitzer 1997) and such substances need to be broken down to low molecular weight compounds and further converted into $\mathrm{NH}_{4}{ }^{+}$to become easily available to plants. These transformations, usually referred to as $\mathrm{N}$ mineralization, are realized by the action of proteolytic enzymes (proteases) released by a wide range of soil microbes (Kumar and Takagi 1999). Proteolytic enzymes differing in the targeted molecules have been described (Landi et al. 2011; Baraniya et al. 2016): (i) the casein proteases (Ladd and Butler 1972) degrade high-molecular weight proteins to smaller compounds and amino acids which can potentially be directly taken up by plant roots (Schimel and Bennett 2004), and (ii) the $\mathrm{N}-\alpha$-benzoyl-L-argininamide (BAA) proteases, which use small size proteinaceous materials as substrate yielding $\mathrm{NH}_{4}{ }^{+}$as end product (Nannipieri et al. 1980). While $\mathrm{NH}_{4}{ }^{+}$can be taken up by plants, it is also prone to nitrification and subsequent losses via nitrate leaching or gaseous emissions in many agricultural soils, especially during the fallow period or when $\mathrm{N}$ uptake by plants and soil microbes is limited (Barton et al. 2011; Sanz-Cobena et al. 2017). Therefore, different relative enzymatic activities in agroecosystems can have strong implications for both plant nutrition and soil microbial activity.

The activity of protease enzymes, similarly to other soil enzymes, is usually induced by the presence of suitable substrate (Geisseler and Horwath 2008) and can be repressed if high amounts of the end product are already present in the soil. Furthermore, the production of enzymes implies high energy and $\mathrm{N}$ investments and, thus, the benefits of protein degradation should exceed the $\mathrm{N}$ costs (Koch 2005). Proteins and amino acids are degraded to increase the availability of both $\mathrm{C}$ and $\mathrm{N}$ for soil microbes; thus, if the concentration of $\mathrm{C}$ in the soil is high or low, the protease activity may be negatively or positively affected, respectively (Geisseler and Horwath 2008). For instance, glomalin-related soil protein (GRSP), an important gluing agent of soil aggregates (Rillig 2004), has been found to influence both $\mathrm{N}$ and $\mathrm{C}$ transformations in soil (Wu et al. 2012), probably related to its high contents of both C (37\%) and N (3$5 \%$ ) (Wright and Upadhyaya 1998; Lovelock et al. 2004). Wu et al. (2012) observed a negative correlation between GRSP content and protease activity but a positive correlation between GRSP content and $\beta$-glucosidase activity (Gls), suggesting that GRSP plays an important role in both $\mathrm{C}$ and $\mathrm{N}$ microbial metabolism. The Gls 
hydrolyzes cellobiose to glucose which is then oxidized to $\mathrm{CO}_{2}$ by the mean of glycolysis and citric acid cycle (Nannipieri et al. 2012) and its activity can be stimulated by $\mathrm{C}$ as well as by $\mathrm{NH}_{4}{ }^{+}$substrate (Geisseler and Horwath 2009). Nevertheless, the specific role of GRSP as substrate for protease seems to be soil-dependent as other authors reported a positive relationship between GRSP and soil proteases (Tang et al. 2009; Gispert et al. 2013).

The sensitivity of soil protease activity to soil moisture, temperature, soil $\mathrm{pH}$, plant cover, organic amendment or substrate availability has been studied extensively (e.g. (Vranova et al. 2013). However, there is a lack of information about the effect of different agronomic practices on soil proteases, impeding an appropriate understanding of the consequences of agronomic management on $\mathrm{N}$ mineralization processes.

The positive effect of NT on soil biological properties have been reported by many authors (Madejón et al. 2009; Martín-Lammerding et al. 2015) especially in the upper soil layers (Vazquez et al. 2017), which is usually linked to the accumulation of soil (SOM) on the surface under NT. Similarly, the liming generally affects positively the soil microbial activity because of the soil Al-toxicity amelioration (Acosta-Martínez and Tabatabai 2000; León et al. 2017), and the enhanced microbial activity has been generally linked to higher soil $\mathrm{N}$ mineralization and $\mathrm{N}$-related enzymatic activity (Haynes and Swift 1988; Feng et al. 2003; Teutscherova et al. 2017a) which could lead to either higher crop $\mathrm{N}$ uptake (Liao et al. 2018) or to increased risk of $\mathrm{N}$ losses via leaching in the absence of crops (Teutscherova et al. 2018). In comparison with other soil hydrolases, the effect of agronomic practices on soil proteases has been paid much less attention, despite the suggestion that they play a crucial role in the maintenance of soil health (Das Kumar Shonkor 2011). As a consequence, our understanding of proteolytic enzymes in soil remains rather limited and, to our best knowledge, there are no studies evaluating the activity of soil protease under the combination of NT agriculture and liming

\subsection{Effects of NT and liming on plant mycorrhization and crop performance}

The positive effect of NT on soil fungal communities is of special relevance in the case of AMF which play a key role in the plant nutrition and soil aggregation (Borie et al. 2006; Dai et al. 2015; Wang et al. 2016). The AMF are obligate symbionts which establish relationships with roots of vascular plants in order to facilitate nutrient 
exchange between host plant and fungus (Smith and Read 2008). In this symbiosis, $\mathrm{AMF}$ depend of $\mathrm{C}$ supply from the roots of host in exchange for mineral nutrients such as $\mathrm{P}, \mathrm{N}$ or micronutrients with low mobility and concentration in soil (Smith and Read 2008). In general, the positive effect of AMF on plant $P$ acquisition is more evident in soils with low P availability (Sorensen et al. 2008; Johnson 2010), meanwhile at high P availability, plants do not benefit from AMF in temrs of $\mathrm{P}$ acquisition and therefore AMF colonization can be disadvantageous for plant growth (Johnson 2010) due to its energy cost. On the other hand, under high available P contents, AMF colonization has been observed to be stimulated by $\mathrm{N}$ deficiency, suggesting that plant promotes AMF colonization if either $\mathrm{N}$ or $\mathrm{P}$ are deficient in soil (Nouri et al. 2014; Teutscherova et al. 2019).

As AMF have shown higher competitivity than plant roots to uptake $\mathrm{NH}_{4}{ }^{+}$which has relatively low mobility in soil, the mycorrhizal symbiosis usually increases the $\mathrm{N}$ plant acquisition rates (Pérez-Tienda et al. 2012). In addition, AMF stimulate $\mathrm{N}$ mineralization by mean of changes in the rhizosphere decomposer populations, leading to a higher N supply for plants (Leigh et al. 2009; Herman et al. 2012). This could be of great importance in NT systems, where the higher SOM in topsoil could increase the mineralized $\mathrm{N}$ acquired by plants and reduce the $\mathrm{N}$ fertilizer doses respect to tilled systems without suppressing the crop yields (Verzeaux et al. 2016). Furthermore, AMF play a key role in the tripartite symbiosis among plant, AMF and rhizobium enhancing the efficiency of the symbiosis and plant growth (Barea et al. 2006). The capacity of AMF to acquire $\mathrm{P}$ covers the high $\mathrm{P}$ demand during nodulation, the rhizobium supplies the plant with $\mathrm{N}$, which in turn sustains AMF through C supply (Barea et al. 2006). Furthermore, AMF play a key role in the benefits of intercropping of legume and nonlegume crops, promoting the transfer of the $\mathrm{N}_{2}$ fixed by legume to the non-legume crop (Jalonen et al. 2009; Meng et al. 2015). Therefore, those agronomic practices able to increase the AMF-plant symbiosis can increase the yields of the crop mixtures reducing the fertilizer requirements.

Other benefit of mycorrhizal symbiosis is the reduction of the $\mathrm{Al}^{3+}$ phytotoxicity impacts on plants in acid soils (Seguel et al. 2013) enhancing the plant growth under acidic stress conditions (Borie and Rubio 1999; Seguel et al. 2016b). Particularly, mycorrhization at earlier stages of growth plays a fundamental role to alleviate the stress caused by $\mathrm{Al}^{3+}$ toxicity and $\mathrm{P}$ deficiency and it is positively related with crop 
yields. (Beggi et al. 2016; Seguel et al. 2016a). On the other hand, alleviation of soil acidity by liming lead to the increase of AMF root colonization due to the enhancement of root growth and plant fitness, which is linked with higher capacity to maintain AMF (Borie and Rubio 1999; Moreira et al. 2010; Cruz-Paredes et al. 2017). However, this impact of liming on AMF is ambiguous as it seems to depend on plant tolerance to $\mathrm{Al}^{3+}$ toxicity (Borie and Rubio 1999; Seguel et al. 2016b).

To my best knowledge, the impact of liming in combination with NT on plantAMF interaction and nutrient uptake has not been studied in spite of its relevance to understand the underlying mechanism of crop performance under the combination of both practices. 


\section{OBJECTIVES}

\subsection{General objectives}

Previous studies have demonstrated the suitability of the combination of NT and liming to restore physical and chemical properties of degraded acid soils and to increase crop yields under Mediterranean conditions (Gómez-Paccard et al. 2013, 2015; Hontoria et al. 2016, 2018). However, there is still gap knowledge in our understanding of the combined impacts of these practices on soil microbial processes involved in nutrient cycling and environmental quality. Therefore, in order to fill this gap, it is essential to consider soil microbiological parameters in the assessment of the impact of both agronomic practices to fully understand their implications on soil quality, crop yields and the environment. Furthermore, as soil (micro)biological properties generally respond faster to land-use change compared to soil physical and chemical parameters, they are of high interest for early detection of the changes in soil health and quality as a consequence of soil management. Accordingly, he general objective of this $\mathrm{PhD}$ Thesis is

"to elucidate the effects of no tillage and liming combination under Mediterranean conditions in the soil microbial activity and the $\mathrm{C}$ and $\mathrm{N}$ cycle, in order to evaluate their suitability for restoring degraded acid soils, increasing crop yields and reducing the environmental impacts of agricultural production".

In order to achieve the general objective, several specific objectives have been defined and each has been targeted with individually tailoted experiments. For a better understanding, objectives were numbered from one to six, and assigned an experiment, which was also numbered from one to six. All the experiments were conducted within the same experimental area: a long-term experimental field located in Cañamero (Cáceres) which is described in the 1.5 section of the Introduction.

\subsection{Specific objectives}

\subsubsection{OBJECTIVE 1:}

"To analyze the impact of different tillage practices (NT vs TT) and liming on soil microbial biomass and enzymatic activity, with a special focus on their temporal variability derived from the seasonality of Mediterranean climate". 
To reach the objective, four soil sampling campaigns during a year (January, April, July, October) were performed in the long-term experimental field. Microbial biomass and EA were investigated. Soil temperature and soil moisture was continuously monitored throughout the year..

We hypothesized that:

H1a: the studied biological parameters will be affected by soil properties changes produced by the different agricultural practices, and that

H1b: those changes will interact with the seasonality of the Mediterranean climate and will therefore vary throughout the year.

\subsubsection{OBJECTIVE 2:}

"To determine the impact of NT and liming on gross N transformation rates during the summer fallow"

To reach this objective, the gross $\mathrm{N}$ transformation rates were performed using the ${ }^{15} \mathrm{~N}$ pool dilution techniquein two sampling events; first after harvest at the end of spring and the second in the middle of the summer fallow. Further, some microbial indicators and the nitrifiers population were determined in order to elucidate the underlying mechanism during this critical period for the $\mathrm{N}$ cycle.

We hypothesized that:

H2a: the combination of NT and liming will increase both gross mineralization and gross nitrification in soil and will lead to an accumulation of mineral $\mathrm{N}$ during the summer period in the upper-most soil layer; that

H2b: higher labile $\mathrm{C}$ content in the top-soil under NT compared to TT will enhance microbial $\mathrm{N}$ immobilization, and that

H2c: all $\mathrm{N}$ transformation rates will be reduced during the fallow period respect to the sampling after harvest with increasing decoupling between ammonification and nitrification with advancing drought. 


\subsubsection{OBJECTIVE 3:}

"To evaluate the impact of tillage practices and liming on $\mathrm{N}_{2} \mathrm{O}$ emissions after soil rewetting and the changes caused in the soil microbial population related to N-cycle and their transcriptional activity".

To reach this objective, soil samples from the long-term experimental plot were collected and rewetted in the laboratory under controlled conditions at different soil moisture intensities and the soil $\mathrm{N}_{2} \mathrm{O}$ emission rate was quantified. In addition, the size, structure and transcriptionally of the $\mathrm{N}$-cycle related genes were evaluated.

We hypothesized that:

H3a: liming will reduce the $\mathrm{N}_{2} \mathrm{O}$ emission with respect to the not amended soil and the decrease of $\mathrm{N}_{2} \mathrm{O}$ will depend on the tillage practices and the intensity of rewetting, that

H3b: liming will increase the size and will change the population structure of denitrifiers and ammonia oxidizing bacteria but will reduce the ammonia oxidizing archea population size, and that

H3c: liming will increase the transcription activity of denitrifiers and ammonia oxidizing bacteria but suppress the ammonia oxidizing archea transcription.

\subsubsection{OBJECTIVE 4:}

"To identify the direct and indirect effects mediated by changes in soil microbial parameters of NT and liming on C and N mineralization using SEM".

To reach this objective, soil samples for the long-term experimental plot were incubated in laboratory under controlled conditions to determine the $\mathrm{C}$ and $\mathrm{N}$ mineralization. In addition, soil chemical and microbial properties were determined. Further, SEM technique was used with latent variables representing the agronomic practices to analyze the synergistic effects and trade-offs of NT and liming amendment on soil $\mathrm{C}$ and $\mathrm{N}$ mineralization and to evaluate the direct or indirect role of microbial biomass, structure and activity in both mineralization processes.

We hypothesized that:

H4a: NT will lead to an increase of $\mathrm{C}$ in soil and will enhance both the microbial biomass and its activity; 
H4b: liming will increase soil $\mathrm{pH}$ and stimulate the microbial activity; that

H4c: $\mathrm{C}$ and $\mathrm{N}$ mineralization will be accelerated by both practices; and

\subsubsection{OBJECTIVE 5:}

"To evaluate protease activity in different soil layers as affected by NT and liming and the implications in $\mathbf{N}$ cycle".

To reach this objective, the BAA and casein protease activities and other chemical and microbiological parameters related to $\mathrm{C}$ and $\mathrm{N}$ cycle were determined in soil samples from three different soil layers.

We hypothesized that:

H5a: the amelioration of soil acidity (driven by liming) and SOM accumulation (due to NT practices) will synergically increase the activity of the studied enzymes, and that

H5b: the effect of both NT and liming practices will be limited to the upper soil layers $(0-5 \mathrm{~cm})$, where most microbial activity takes place.

\subsubsection{OBJECTIVE 6:}

"To evaluate the impact of tillage practices and liming on mycorrhizal symbiosis, plant growth and $N$ and $P$ contents of oat and vetch mixed crop".

To reach this objective, soil and plants were sampled three times during a growing season. Soil nutrient contents, plant biomass, $\mathrm{N}$ and $\mathrm{P}$ contents and mycorrhization were evaluated in both oat and vetch. In addition, the crop yield and $\mathrm{N}$ and $\mathrm{P}$ uptake at harvest were determined.

We hypothesized that:

H6a: NT and liming combination will increase the growth of both plants and their uptake of $\mathrm{N}$ and $\mathrm{P}$, that

H6b: root AMF colonization will be higher in the combination of NT and liming and that

H6c: the highest effect of treatments on root colonization will be detected at the earlier stages of growth. 


\section{MATERIALS AND METHODS}

\subsection{Detritic raña formations: The Raña of Cañamero}

The rañas are flat detritic formations from middle-Pliocene formed near the quartzitic ranges in the west of the Iberian Peninsula which cover more than $10^{6}$ ha (Espejo Serrano 1985; Espejo 1987; Peregrina et al. 2008). The soils were developed under subtropical pre-Quaternary climate (i.e. hot and wet summers) and retained their typical features until present times: they are highly weathered with kaolinite as the main clay component, very low $\mathrm{pH}$ which further decreases with depth and the exchange complex is dominated by $\mathrm{Al}^{3+}$ (Espejo 1987). The soils are probably the oldest no-fossil soils described in the Mediterranean region (Espejo 1987) and whole Europe and were developed during middle-Pliocene and the soils maintain the main characteristics of the pre-Quaternary subtropical climate..

The raña of Cañamero formation is located predominantly in Cañamero township $39^{\circ} 19^{\prime} \mathrm{N}$ and $5^{\circ} 21^{\prime} \mathrm{W}$, Cáceres (SW Spain). The surface of the platform is $26 \mathrm{~km}^{2}$ large and the center is located approximately at $588 \mathrm{~m}$ above sea level (a.s.1.), ranging between 645 and $515 \mathrm{~m}$ a.s.l. and the average slope is $0.7 \%$. The raña of Cañamero is related to the Paleozoic quarzitic range of Las Villuercas. According to Espejo (1987), the Cañamero Raña are classified as Plinthic Palexerults or Xeric Palehumults (USDA, 2014), equivalent to Plinthic Acrisol or Acric Umbrisol (IUSS Working Group WRB 2015) depending on their degradation status.

Until the beginning of the $20^{\text {th }}$ century, the area was covered with natural vegetation since the generally low fertility of these soils made them not suitable/adeaquate for agricultural production. Nevertheless, the food scarcity after the Spanish civil war (1936-39) caused the clearance of the natural vegetation and initiation of agricultural activity (Espejo 1987). The previous climax vegetation was formed by scattered cork oak trees (Quercus suber L.) surrounded by strawberry trees (Arbutus unedo L.) and false olive (Phillyrea angustifolia L.) shrubs of the Phillyreo-Arbutetum tipicum association (Rivas Goday 1964). After the vegetation clearance, the continuous tillage and excessive use of fertilizers led to dramatic decrease of the SOC, increase of the $\mathrm{Al}^{3+}$ toxicity and degradation of soil physical properties, causing the cropland abandonment (Mariscal et al. 2007; Peregrina et al. 2008). 

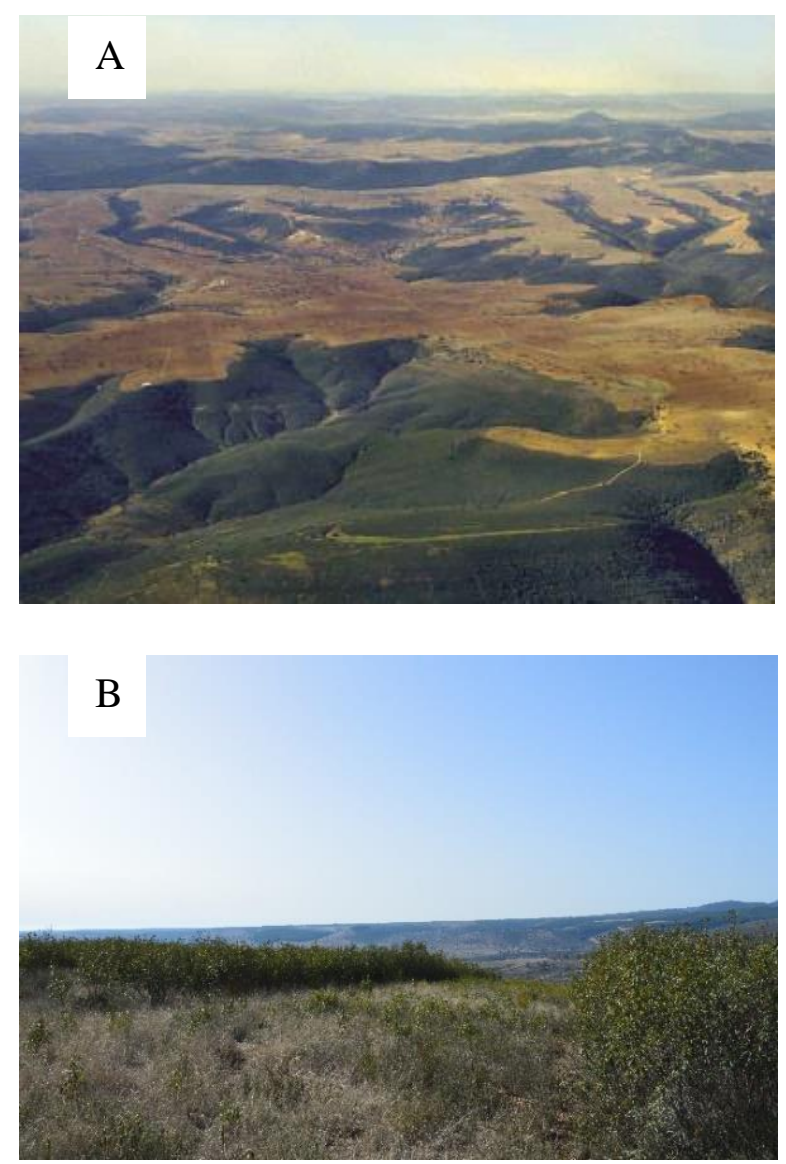

Fig. 3.1.1: Aerial photography of Cañamero raña (A) (source: Junta de Extremadura) and the raña flat profile (B) (photo by Eduardo Vázquez).

\subsection{Experimental site and previous management}

\subsubsection{Previous land-use and experimental area establishment}

An experiment was established in 2005 on the flatlands of the raña of Cañamero $\left(39^{\circ} 19^{\prime} 7^{\prime \prime} \mathrm{N}, 5^{\circ} 19^{\prime} 33^{\prime \prime} \mathrm{W}\right)$ at the altitude of $580 \mathrm{~m}$ a.s.l.. The climate of the area is moist Mediterranean (Csa) according to Köppen's classification. The mean annual precipitation is $869 \mathrm{~mm}$ and the mean annual evapotranspiration is $1248 \mathrm{~mm}$ (using the Penman-Monteith method) (Gómez-Paccard et al. 2013). The soil in the study site was characterized by the dominance of kaolinite in the clay fraction, soil $\mathrm{pH}$ ranging of 5.2 (surface) and as low as 4.5 further down the profile. The soil properties prior the experiment establishment can be seen in Table 3.2.1. The soil is classified as Plinthic Palexerults (USDA, 2014) or Plinthic Acrisol (IUSS Working Group WRB 2015). 

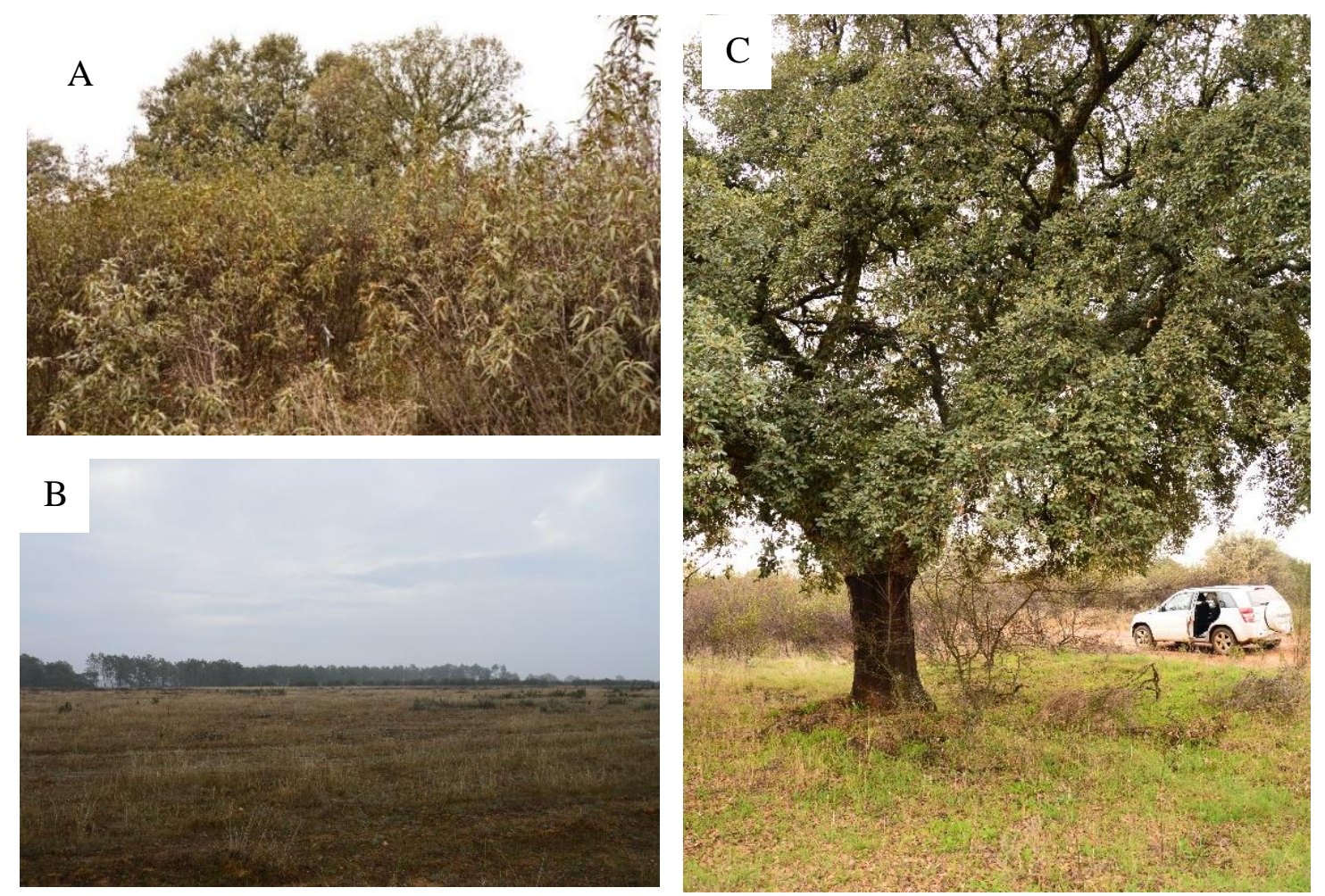

Fig. 3.2.1: Natural revegetation after land abandonment (A), natural grassland in former cropland (B) and a relict cork oak 8C) (photos by Eduardo Vázquez)

Table 3.2.1: Soil properties of a representative profile in the experimental area

\begin{tabular}{|c|c|c|c|c|c|c|c|c|c|c|c|c|}
\hline \multirow[t]{2}{*}{ Horizon $(\mathrm{cm})$} & \multirow[t]{2}{*}{$\begin{array}{l}\text { SOM } \\
(\%)\end{array}$} & \multicolumn{2}{|l|}{$\mathrm{pH}$} & \multirow[t]{2}{*}{$\mathrm{Al}^{3+}$} & \multicolumn{4}{|c|}{$\begin{array}{l}\text { Exchangeable cations } \\
\left(\mathrm{cmolc} \mathrm{kg}^{-1}\right)\end{array}$} & \multirow[t]{2}{*}{$\begin{array}{l}\mathrm{RF} \\
(\%)\end{array}$} & \multicolumn{3}{|c|}{$\begin{array}{l}\text { Texture } \\
(\%)\end{array}$} \\
\hline & & $\mathrm{H}_{2} \mathrm{O}$ & $\mathrm{KCl}$ & & $\mathrm{Ca}^{2+}$ & $\mathrm{Mg}^{2+}$ & $\mathrm{Na}^{+}$ & $\mathrm{K}^{+}$ & & Sand & Silt & Clay \\
\hline Ap $(0-25 \mathrm{~cm})$ & 3.38 & 5.3 & 4.3 & 0.76 & 1.12 & 0.21 & 0.05 & 0.65 & 52 & 80.1 & 6.1 & 13.8 \\
\hline $\mathrm{AB}(25-35 \mathrm{~cm})$ & 1.59 & 5.0 & 4.0 & 1.01 & 0.85 & 0.16 & 0.04 & 0.08 & 47 & 69.1 & 5.6 & 25.3 \\
\hline $\mathrm{Bt}(35-90 \mathrm{~cm})$ & 0.25 & 4.9 & 3.7 & 1.75 & 0.82 & 0.11 & 0.03 & 0.07 & 56 & 59.59 & 4.7 & 35.4 \\
\hline Btv $(90-200)$ & nd & 4.6 & 3.4 & 2.23 & 1.12 & 0.10 & 0.05 & 0.06 & 75 & 56.0 & 5.1 & 38.9 \\
\hline
\end{tabular}

$\mathrm{SOM}$, organic matter; $\mathrm{Al}^{3+}: \mathrm{KCl}$-Extractable; $\mathrm{RF}$, rock fragments $>2 \mathrm{~mm}$ Adapted from Gomez-Paccard et al. (2013)

This area was managed as a tilled cropland from 1940 to 1990, and subsequently abandoned due to advancing soil degradation and linked drop of soil productivity (Gómez-Paccard et al. 2013). During the following 15 years, soil was naturally revegetated by natural pastures and shrubs of basil-leaved rock rose (Halimum ocymoides L.) and gum rockrose (Cistus ladanifer L.) (Mariscal-Sancho et al. 2009). In September 2005, the area was homogenized by two passes of cultivator which cleared the natural vegetation. Then, the area was tilled with power tiller (one pass) to the depth of $20 \mathrm{~cm}$. At this stage, 16 plots $(16 \times 4 \mathrm{~m}$ each) were marked in a split-plot design as seen on the Fig. 3.2.2. 

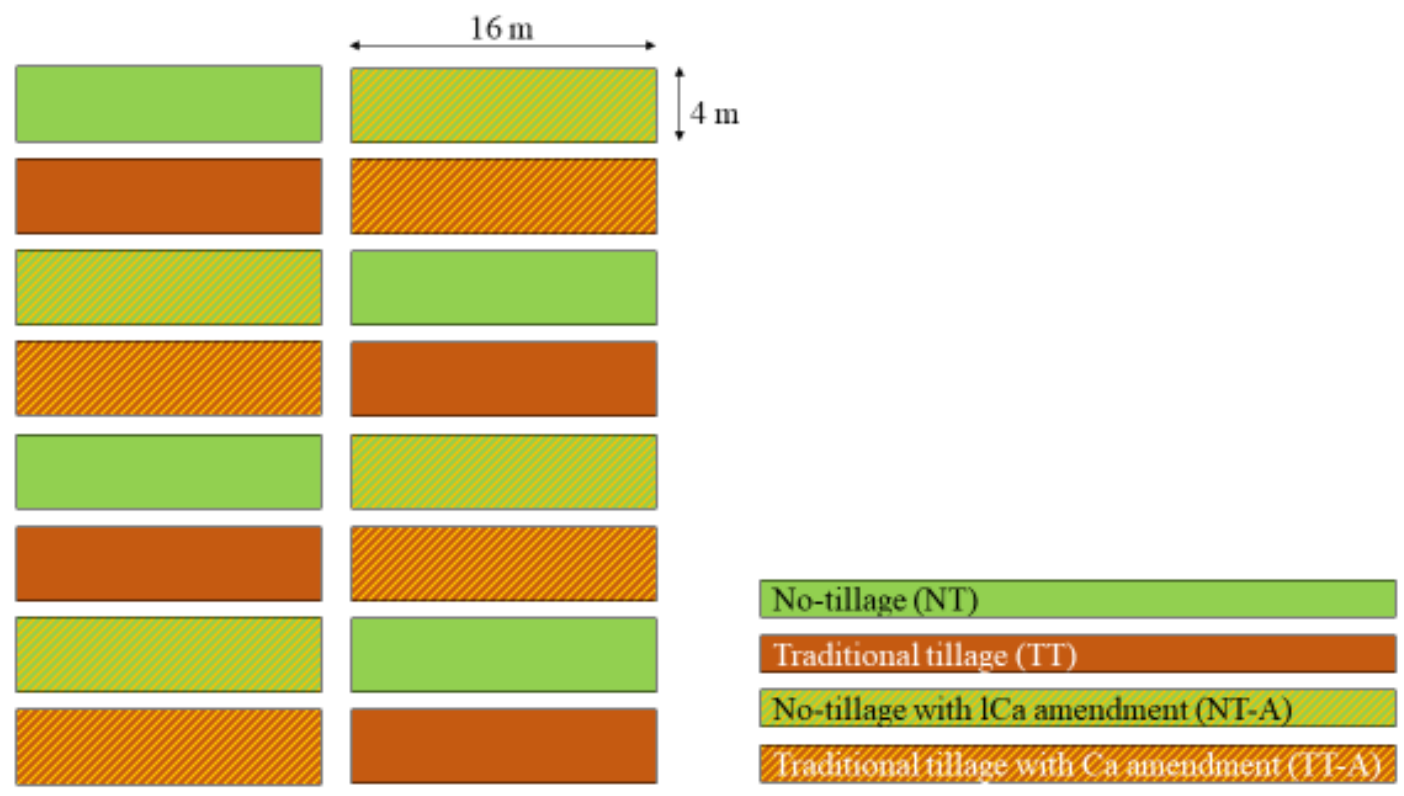

Fig. 3.2.2: Lay-out of the field experiment

The studied factors included tillage: no-tillage (NT) versus traditional tillage (TT) and liming amendment application: amended plots versus control plots without liming amendment and their conbination. Overall, four treatments were considered: NT (notillage without liming amendment), TT (traditional tillage without liming amendment), NT-A (no-tillage with liming amendment), and TT-A (traditional tillage with liming amendment).

A mixture of sugar foam waste (SF) and ref gypsum (RG) was used as liming amendment. The SF is a by-product of the sugar beet purification, rich in lime and also other nutrients such $\mathrm{Mg}, \mathrm{P}$ or S and organic matter. While SF has been observed to be economically accessible substitution of the more expensive $\mathrm{CaCO}_{3}$, the advantage of RG lays in the fact that this material can reach deeper soil layers and alleviate soil acidity deeper horizons and subsoil (Peregrina et al. 2006). The properties of both used materials can be found in Table 3.2.3.

The amendment was applied three times since the beginning of the experiment in 2005, in application rates calculated for seven years (September 2005, the establishment of the experiment), for two years (October 2012) and for four years (October 2014). In addition, in the two first amendments, the $\mathrm{Ca} / \mathrm{Mg}$ ratio was balanced applying $\mathrm{MgO}$ in form of converter basic slag (CBS) and $\mathrm{MgSO}_{4}$. The overview of the amounts of the 
applied liming materials can be seen in Table 3.2.3. In 2005, at the establishment of the experiment, lime amendment was incorporated to the upper $0-7 \mathrm{~cm}$ soil layer. Since then, the NT plot remained without tillage while TT plots were tilled every autumn (depth $20 \mathrm{~cm}, 2$ passes) for soil preparation and weed control. Therefore, in the second and third liming amendment, the mixture was spread in the surface of NT-A plots and incorporated by tillage in the TT-A.

Table 3.2.2: Chemical composition of used amendments

\begin{tabular}{|c|c|c|}
\hline Component & $\begin{array}{l}\mathrm{SF} \\
\left(\mathrm{g} \mathrm{kg}^{-1}\right)\end{array}$ & $\begin{array}{l}\mathrm{RG} \\
\left(\mathrm{g} \mathrm{kg}^{-1}\right)\end{array}$ \\
\hline $\mathrm{CaO}$ & 437 & 231 \\
\hline $\mathrm{SO}_{4}^{2-}$ & 5.1 & 465 \\
\hline $\mathrm{SiO}_{2}$ & 17.3 & 11.2 \\
\hline $\mathrm{P}_{2} \mathrm{O}_{6}$ & 8.10 & n.d. \\
\hline $\mathrm{MgO}$ & 47.3 & 1.5 \\
\hline $\mathrm{Al}_{2} \mathrm{O}_{3}$ & 24.2 & 12.3 \\
\hline $\mathrm{K}_{2} \mathrm{O}$ & 1.95 & $<0.5$ \\
\hline $\mathrm{Fe}_{2} \mathrm{O}_{3}$ & 1.31 & 38.8 \\
\hline $\mathrm{Na}_{2} \mathrm{O}$ & 1.05 & 0.90 \\
\hline $\mathrm{MnO}$ & $<0.1$ & 1.10 \\
\hline OM & 86.7 & n.d. \\
\hline Lime * & 765 & n.d. \\
\hline Active lime ${ }^{* *}$ & 213 & n.d. \\
\hline $\mathrm{LI}^{* * *}$ & 468 & 162 \\
\hline
\end{tabular}

$S F$ sugar foam; $R G$ red gypsum; n.d.: not detected; ${ }^{*}$ Total calcium equivalent; ${ }^{* *}$ Calcium carbonate reactive with ammonium oxalate; ${ }^{* * *}$ Loss on ignition. Adapted from Gomez-Paccard et al. (2013)

Table 3.2.3: Summary of liming amendments dates of application, amount and form of application

\begin{tabular}{|c|c|c|c|c|c|c|}
\hline \multirow[t]{2}{*}{ Date of application } & \multirow[t]{2}{*}{$\mathrm{SF}$} & \multirow[t]{2}{*}{ RG } & \multicolumn{2}{|c|}{$\mathrm{MgO}$} & \multicolumn{2}{|c|}{ Form of application } \\
\hline & & & \multicolumn{2}{|c|}{$\mathrm{Kg} \mathrm{ha}^{-1}$} & $\mathrm{TT}$ & NT \\
\hline $09 / 2005$ & 3.90 & 7.50 & 100 & 100 & Incorporated & Incorporated \\
\hline $10 / 2012$ & 1.11 & 2.14 & 28.6 & 28.6 & Incorporated & Surface \\
\hline $10 / 2014$ & 2.23 & 4.28 & - & - & Incorporated & Surface \\
\hline
\end{tabular}

In the period 2005-2012 a mixture (57-26-17) of local varieties of oat (Avena sativa L.) vetch (Vicia sativa L.) and triticale (X Triticosecale Wit.) was sown, except for the 2009-2010 growing season, when rapeseed (Brassica napus L.) was used instead. In the 2012-2013 season the only sown crop was triticale, while in the 20132016 period the crop mixture was a mixture of oat (74\%) and vetch (26\%).

The winter crops are always sown in October or November after the first autumn rains. The TT treatments were tilled and the seeding was done in all treatemtns using a direct sowing machine. In NT plots, weed control was achieved using glyphosate (36\% purity) at $2.5 \mathrm{~L} \mathrm{ha}^{-1}$ dose before seeding. Mineral fertilizer (36 kg N ha ${ }^{-1}, 72 \mathrm{~kg} \mathrm{~K} \mathrm{ha}^{-1}$ 
and $72 \mathrm{~kg} \mathrm{P} \mathrm{ha}{ }^{-1}$ ) was applied before sowing. At the end of each growing season, the aboveground biomass was harvested (June or July) for forage at $20 \mathrm{~cm}$ above the soil surface and the stubble was mantained in the soil surface during the summer fallow when it was incorporated by tillage in TT treatments.

The current thesis covered several experiments performed during two agronomic seasons, 2014/15 and 2015/16. In the 2014/15 season, the mentioned mixture of oat and vetch was sown at the end of October 2014 and harvested at the first week of June 2015. In the 2015/16, the crop was sown in the beginning of November 2015 and harvested the last week of May 2016.

\subsubsection{Sampling scheme and particular experiments}

A total of six different experiments were performed to assess the different proposed objectives. Two of them (Experiment 1 and 4) were done during the agronomic season 2014/15 and the other four (Experiment 2, 3, 5 and 6) during the season 2015/16. The different samplings of each experiment are summarized in the Fig. 3.2.3. In the next sections the detailed sampling scheme and complete methodology is described for each particular experiment.

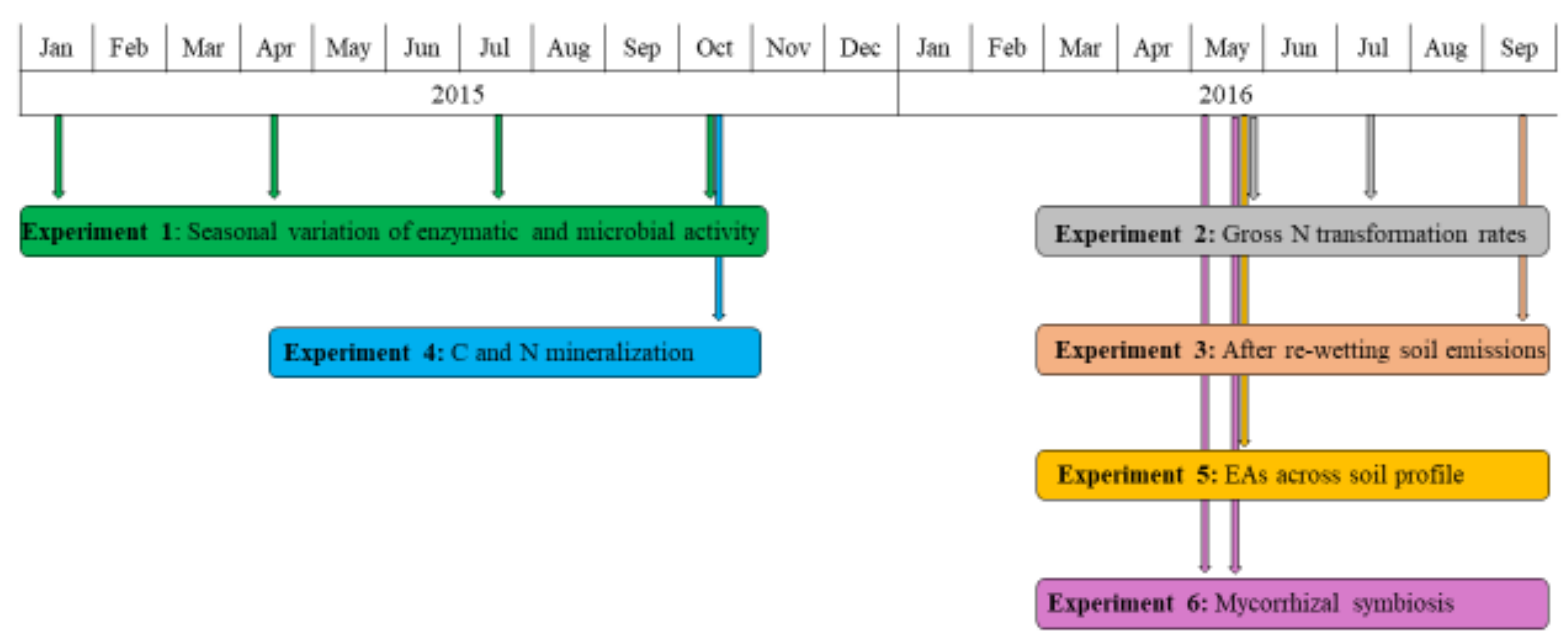

Fig. 3.2.3: Sample collection dates for all experiments included in the present thesis.

\subsubsection{Experiment 1: Seasonal variation of enzymatic and microbial activity}

\subsubsection{Samples collection}

Samples were collected four times during the year between January 2015 and October 2015 (January, April, July and October) from two depths (0-5 cm and 5-10 $\mathrm{cm}$ ). During each sampling event, a composite sample of three subsamples was 
collected from each plot. Field-moist soil was transported to laboratory and sieved $(<2$ $\mathrm{mm}$ ) on the same day. A subsample of $200 \mathrm{~g}$ was stored at $4{ }^{\circ} \mathrm{C}$ until the analyses of microbial biomass and soil enzymes activity were performed (within one week) and the rest of the soil was air-dried for chemical analysis.

\subsubsection{Field measurements}

Soil temperature was monitored hourly during the whole study period using temperature registers (DS1922L Thermochron iButton, AlphaOmega Electronics; Madrid, Spain) placed at a depth of $5 \mathrm{~cm}$. Three data loggers were placed randomly in NT plots and other three in TT plots. Moreover, each month samples were taken from all treatments and both depths for determination of gravimetric water content (GWC) by oven drying at $105^{\circ} \mathrm{C}$ until constant weight.

\subsubsection{Laboratory analysis}

Soil chemical properties: Soil $\mathrm{pH}$ was determined in water slurry $(1: 2.5)$ with selective electrode. Dichromate oxidation method was used for analysis of SOC (Walkley and Black 1934). Permanganate oxidizable C (POxC) was quantified colorimetrically based on method of Weil et al. (2003).

Microbial biomass and respiration: Microbial biomass $\mathrm{C}$ and $\mathrm{N}$ (MBC and MBN, respectively) were estimated by fumigation-extraction method (Vance et al. 1987) by fumigating $15 \mathrm{~g}$ of soil with ethanol-free chloroform followed by $0.5 \mathrm{M}$ $\mathrm{K}_{2} \mathrm{SO}_{4}$ extraction (1:4 soil:extractant ratio). The concentration of organic $\mathrm{C}$ in the extract was determined colorimetrically by measuring $\mathrm{Cr}^{3+}$ produced by reduction of $\mathrm{Cr}^{6+}(578 \mathrm{~nm})$ after microwave digestion at $135^{\circ} \mathrm{C}$ for 30 minutes. Nitrogen content was determined by Kjeldahl digestion of extracts (Bremner and Mulvaney 1982). Microbial biomass $\mathrm{C}$ and $\mathrm{N}$ were calculated as the difference between the $\mathrm{C}$ and $\mathrm{N}$ content in fumigated and non-fumigated samples, divided by 0.38 (Joergensen 1996a) and 0.54 (Brookes et al., 1985), respectively. Basal respiration (BR) was determined by 3 days of aerobic incubation of pre-incubated (three days at $25^{\circ} \mathrm{C}$ to avoid an overestimation because of the soil manipulation (Creamer et al. 2014)) samples using alkaline $\mathrm{NaOH}$ trap followed by titration with $\mathrm{HCl}$ after carbonates precipitation with $\mathrm{BaCl}_{2}$ (Iannotti et al. 1993). Soil moisture was adjusted to $60 \%$ of field capacity (FC) with deionized water when it was necessary before the pre-incubation period. Similarly, when the soil moisture exceeded the $60 \%$ of FC, the samples were air dried at room temperature until 
the moisture content around the $50 \%$ of FC was reached and were watered to the $60 \%$ before the beginning of the pre-incubation period.

Soil enzymatic activities: Dehydrogenase activity (DHase) was determined using 2-(4-Iodophenyl)-3-(4-nitrophenyl)-5-phenyltetrazolium chloride (INT) as a substrate using method of Trevors et al. (1982) modified by García et al. (1993). For $\beta$ glucosidase activity (Gls) method of Hoffmann and Dedeken (1965) modified by Strobl and Traunmueller (1996) was selected using $\beta$-glucoso-saligenin (salicin) as substrate. The $\beta$-glucosaminidase activity (Glm) was determined according to method proposed by Parham and Deng (2000) with p-nitrophenyl-N-acetyl- $\beta$-D-glucosaminide as substrate. Acid phosphomonoesterase activity (PHase) and arylsulphatase activity (ASase) were determined using the methods of Tabatabai and Bremner (1969) and of Tabatabai and Bremner (1970), respectively. For the activity of urease, method proposed by Kandeler and Gerber (1988) and modified by Kandeler et al. (1999) was selected and the activity was determined as $\mathrm{NH}_{4}{ }^{+}-\mathrm{N}$ produced during the incubation.

\subsubsection{Statistical analysis}

Data were analyzed statistically with a linear mixed model for all four sampling dates using the SPSS 19 software (IBM SPSS, Inc., Chicago, USA). The depth of the sampling (Dpt), the different soil tillage (T), the liming amendment (A) and the sampling date (Dt) were considered fixed effects, and the different plots $(n=16)$ were consider a random effect. The mean values of the sampling dates were separated using a LSD post hoc test $(\mathrm{p}<0.05)$. The model was used with a full factorial design. The data of soil GWC were grouped only by tillage $(n=8)$ to reduce the data set because no effect of A was found in preliminary statistical analyses. The GWC of the soil in the 12 sampling dates was performed using a General Linear Model for each different sampling date and Dpt, with $\mathrm{T}$ as a fixed factor. Correlations between variables at each soil sampling were examined by principal components analyses (PCA) using SPSS 19. The principal components were extracted through Varimax orthogonal rotation. A calculated variable called GWC3m was included in PCA and it was the mean of the GWG of the last three months before each soil sampling (data not shown). Additionally, PCA was performed for all sampling dates together and the sampling points were plotted in the space defined by PC1 and PC2 (presented in the S1 Supplementary Material). Student's t-test was used to compare the significant differences between the soil temperature registers 
placed in TT and NT $(\mathrm{p}<0.05)$. All $\mathrm{p}$ values in text are from linear mixed model unless otherwise specified.

\subsubsection{Experiment 2: Gross $\mathbf{N}$ transformation rates during summer fallow}

\subsubsection{Samples collection}

Soil samples from the $0-10 \mathrm{~cm}$ soil layer were collected on the harvest day (May $\left.31^{\text {th }} 2016\right)$ and on July $21^{\text {th }} 2016$. These dates were intentionally selected to target the initial conditions prior to the fallow and the middle of the fallow period under severe drought and heat conditions. During each sampling, ten sub-samples per plot randomly distributed within its area were collected. Subsamples were then pooled together to obtain a composite sample of approximately two $\mathrm{kg}$ from each plot. The soil samples were placed in plastic bags, transported immediately to laboratory and sieved to $2 \mathrm{~mm}$ on the same day. A subsample of each composite, homogenized sample was stored at $20{ }^{\circ} \mathrm{C}$ for later DNA extractions; one subsample was stored at $4{ }^{\circ} \mathrm{C}$ for microbial biomass determination and enzymatic activities; one subsample was used immediately used for the isotope labeling and the rest of the soil was air-dried for chemical analysis. In addition, two intact soil cores per plot were collected at 0-5 cm and 5-10 cm depth using steel rings of $5 \mathrm{~cm}$ of diameters for bulk density determinations. Although mineral $\mathrm{N}$ and other soluble compounds may have accumulated in the deeper soil layers, we considered that this should not be an issue under fallow period with minimum rainfall.

\subsubsection{Laboratory analysis}

Soil moisture, temperature and chemical properties: Soil moisture was determined as GWC which was quantified by oven drying at $105{ }^{\circ} \mathrm{C}$ until constant weight. Soil bulk density was calculated by dividing the soil dry mass of the intact soil cores by its volume. An average value between $0-5$ and $5-10 \mathrm{~cm}$ soil bulk density was used to obtain the soil bulk density for the $0-10 \mathrm{~cm}$ soil layer. Water filled pore space (WFPS) was calculated by dividing the volumetric water content (calculated as GWC*soil bulk density/water density) by total soil porosity, while total soil porosity was calculated according to: soil porosity $=1-$ (soil bulk density/2.65) assuming a soil particle density of $2.65 \mathrm{~g} \mathrm{~cm}^{-3}$ (Danielson and Sutherland, 1986). Soil pH was determined in water slurry (1:2.5) with selective electrode. Dichromate oxidation method was used for analysis of SOC (Walkley and Black 1934). Total Nitrogen content $(\mathrm{TN})$ was determined by Kjeldahl digestion followed by steam distillation (Bremner and Mulvaney 1982). 
Microbial biomass, inorganic nitrogen and dehydrogenase activity: The MBC and MBN were quantified using the fumigation-extraction method proposed by Vance et al. (1987). Briefly, $15 \mathrm{~g}$ of fresh soil were fumigated with ethanol-free chloroform followed by $0.5 \mathrm{M} \mathrm{K}_{2} \mathrm{SO}_{4}$ extraction (1:4 soil:extractant ratio). Control samples were extracted in the same way without previous fumigation. The concentration of organic $\mathrm{C}$ in the extracts was determined colorimetrically (UV-1203, Shimadzu, Kyoto, Japan) against glucose standard curve. Nitrogen content of the extracts was determined by Kjeldahl digestion and steam destillation (Bremner and Mulvaney 1982). The MBC and MBN were calculated as the difference between the $\mathrm{C}$ and $\mathrm{N}$ content in fumigated and non-fumigated samples, divided by 0.38 (Joergensen 1996b) and 0.54 (Brookes et al., 1985), respectively. Inorganic $\mathrm{N}$ was extracted with $2 \mathrm{M} \mathrm{KCl}(1: 10)$ and $\mathrm{NH}_{4}{ }^{+}-\mathrm{N}$ and $\mathrm{NO}_{3}{ }^{-}-\mathrm{N}$ contents were determined colorimetrically (UV-1203, Shimadzu, Kyoto, Japan) using the methods proposed by Forster (1995) and Miranda et al. (2001), respectively. Organic $\mathrm{C}$ concentrations obtained in the non-fumigated controls of $\mathrm{MBC}$ determination were referred to as extractable DOC, while the extractable DON was calculated subtracting the inorganic $\mathrm{N}\left(\mathrm{NH}_{4}{ }^{+}-\mathrm{N}+\mathrm{NO}_{3}{ }^{-}-\mathrm{N}\right)$ from the total $\mathrm{N}$ of the non-fumigated controls of MBN. In addition, DHase was determined using 2-(4-Iodophenyl)-3-(4nitrophenyl)-5-phenyltetrazolium chloride (INT) as a substrate following the method of Trevors et al. (1982) as modified by García et al. (1993).

Gross nitrogen transformation rates: The ${ }^{15} \mathrm{~N}$ pool dilution technique was used with disturbed and sieved soil because the high content of rock fragments and gravel (44-49\% according to Gómez-Paccard et al. 2015) would have complicated the homogenous distribution of ${ }^{15} \mathrm{~N}$ into intact cores. In order to reduce the possible artifacts of samples storage and transport (Gütlein et al. 2016) soil was sieved and ${ }^{15} \mathrm{~N}$ labeled within 24 hours since sampling. With the exception of the use of altered and sieved samples, the gross ammonification and nitrification rates analyses were performed with the soils taken in May and July as described in (Dannenmann et al. 2006). Briefly, a soil sample of $100 \mathrm{~g}$ from each plot was labeled with either $30 \%$ $\mathrm{K}^{15} \mathrm{NO}_{3}$ or $30 \%\left({ }^{15} \mathrm{NH}_{4}\right)_{2} \mathrm{SO}_{4}$ for the determination of gross nitrification or gross ammonification rates, respectively. In both cases, $30 \mathrm{~mL} \mathrm{~kg}^{-1}$ dry soil of ${ }^{15} \mathrm{~N}$ solution was applied in a rate of $5 \mathrm{mg} \mathrm{N} \mathrm{kg}^{-1}$ dry soil (which means a surplus of $56 \%$ of the inorganic $\mathrm{N}$ pool in the soil) and the soil was mixed carefully in order to ensure a maximum homogeneity of the labeling solution distribution. Each sample was then 
divided into two subsamples of $30 \mathrm{~g}$, which were transferred into $250 \mathrm{~mL}$ plastic bottles and the rest of the labeled soil was used to determine the GWC as described above.

The plastic bottles with labeled soil from May and July sampling campaigns were incubated at $22^{\circ} \mathrm{C}$ and $37^{\circ} \mathrm{C}$, respectively, which corresponds to the mean soil temperature during the last two weeks prior sampling May and July sampling, respectively (Fig. 3.2.4). After $24 \mathrm{~h}$ of incubation, the labeled soil from one of each pair of bottles was extracted with $60 \mathrm{~mL}$ of $0.5 \mathrm{M} \mathrm{K}_{2} \mathrm{SO}_{4}$ whereas the remaining bottle of the pair underwent further incubation for another $24 \mathrm{~h}$ before being extracted in the same way. Both extracts were immediately filtered as described by Dannenmann et al. (2006) and the $\mathrm{NH}_{4}{ }^{+}-\mathrm{N}$ and $\mathrm{NO}_{3}{ }^{-}-\mathrm{N}$ contents were determined colorimetrically as described above (Forster, 1995; Miranda et al. 2001). An aliquot of the extracts were frozen at $20^{\circ} \mathrm{C}$ and transported to the laboratory of Institute of Meteorology and Climate Research, Karlsruhe Institute of Technology (IMK-IFU/KIT, Garmisch-Partenkirchen, Germany) in thermo-isolated boxes within $24 \mathrm{~h}$. Extracts were kept frozen until the analysis. ${ }^{15} \mathrm{~N}$ enrichment of $\mathrm{NH}_{4}{ }^{+}$and $\mathrm{NO}_{3}{ }^{-}$pools were quantified after the diffusion of $\mathrm{NH}_{4}{ }^{+}$and $\mathrm{NO}_{3}{ }^{-}$on acid traps by isotope ratio mass spectrometry as described in Dannenmann et al. (2009). The gross ammonification and gross nitrification rates were calculated following the equations described by Kirkham and Bartholomew (1954). Microbial immobilization of $\mathrm{NH}_{4}{ }^{+}$was calculated as ${ }^{15} \mathrm{NH}_{4}{ }^{+}$production minus gross nitrification, assuming that gaseous losses and heterotrophic nitrification of organic $\mathrm{N}$ were negligible (Davidson et al. 1991) while microbial $\mathrm{NO}_{3}^{-}$immobilization was assumed to equal $\mathrm{NO}_{3}{ }^{-}$consumption.

DNA extraction: The DNA was extracted from $0.25 \mathrm{~g}$ (fresh weight) of soil using the Power Soil DNA Isolation Kit (MoBIO Laboratories, Carlsbad, CA, USA), according to the manufacturer's instructions. The concentration and purity of extracted DNA were determined by 260/280 $\mathrm{nm}$ and 260/230 $\mathrm{nm}$ measurements using a Nanodrop spectrophotometer (DeNovix, Wilmington, DE, USA).

Real-time PCR quantification: Quantitative PCR (qPCR) was performed to assess the abundance of the following genes: 16S rRNA gene for total bacteria, ITS for total fungi and amoA gene for both AOA and AOB. The qPCR was performed in reaction mixtures $(20-\mu \mathrm{L})$ with $10 \mu \mathrm{L}$ of SYBR GreenER ${ }^{\mathrm{TM}}$ qPCR SuperMix (Invitrogen, NJ, USA), $0.5 \mu \mathrm{M}$ of each primer (Table 3.2.4) and $4 \mu \mathrm{L}$ of diluted DNA extracts using an Applied Biosystems ABI 7300 (Applied Biosystems, NJ, USA) 
sequence detection system starting with the initial denaturation step at $95{ }^{\circ} \mathrm{C}$ for 10 minutes, followed by amplification cycles specific for each target gene (Table 3.2.4). After each run, a melting curve analysis was performed. The $\mathrm{R}^{2}$ values for the standard curves were 0.99 or higher in all runs. The standard curves for quantifying gene copy numbers were determined by cloning the PCR products in a plasmid as described by Okano et al. (2004). The population sizes of total bacteria, total fungi, AOB, and AOA were estimated as the normalized copies per gram of dry soil.

\subsubsection{Statistical analysis}

Data were analyzed statistically with a Linear Mixed Model using the SPSS 22 software (IBM SPSS, Inc., Chicago, USA). The sampling date (Dt), soil tillage (T) and the liming amendment (A) were used as fixed factors, while the plot $(n=16)$ and the block $(n=4)$ were used as random factors. Bivariate correlations were determined by the Pearson's correlation coefficients. For identification processes related to gross $\mathrm{N}$ transformations, separate stepwise regressions were applied for each $\mathrm{N}$ transformation rate with the significance level set at $\mathrm{p}=0.05$.

Table 3.2.4: Target genes, used primers and qPCR conditions

\begin{tabular}{|c|c|c|}
\hline Target gene & $\begin{array}{l}\text { Primers / Sequence }\left(5^{\prime}-3^{\prime}\right) \\
\text { (reference) }\end{array}$ & qPCR \\
\hline AOB-amoA & $\begin{array}{l}\text { amoA-F/ GGGGTTTCTACTGGTGGT } \\
\text { amoA -R/ CCCCTCKGSAAAGCCTTCTTC } \\
\text { (Rotthauwe et al. 1997) }\end{array}$ & $\begin{array}{l}95^{\circ} \mathrm{C} 10 \mathrm{~min} ; 40 \text { cycles: } 95^{\circ} \mathrm{C} 45 \mathrm{~s}, \\
58^{\circ} \mathrm{C} 45 \mathrm{~s}, 72^{\circ} \mathrm{C} 45 \mathrm{~s}\end{array}$ \\
\hline AOA-amoA & $\begin{array}{l}\text { amoArs-F/ STAATGGTCTGGCTTAGACG } \\
\text { amoArs-R/ GCGGCCATCCATCTGTATGT } \\
\text { (Francis et al. 2005) }\end{array}$ & $\begin{array}{l}95^{\circ} \mathrm{C} 10 \mathrm{~min} ; 40 \text { cycles: } 95^{\circ} \mathrm{C} 45 \mathrm{~s}, \\
55^{\circ} \mathrm{C} 45 \mathrm{~s}, 72^{\circ} \mathrm{C} 45 \mathrm{~s}\end{array}$ \\
\hline ITS & $\begin{array}{l}\text { ITS5-F /GGAAGTAAAACTCCGTAACAAGG } \\
\text { ITS4-R/TCCTCCGTCTATTGATATGC } \\
\text { (Schoch et al. 2012) }\end{array}$ & $\begin{array}{l}50^{\circ} \mathrm{C}, 2 \mathrm{~min} ; 95^{\circ} \mathrm{C} 5 \mathrm{~m} ; 1 \text { cycle: } 95^{\circ} \mathrm{C} \\
1 \mathrm{~m}, 55^{\circ} \mathrm{C} 1 \mathrm{~m}, 72^{\circ} \mathrm{C} 45 \mathrm{~s}, 45 \text { cycles: } \\
95^{\circ} \mathrm{C} 15 \mathrm{~s}, 60^{\circ} \mathrm{C} 30 \mathrm{~s}, 95^{\circ} \mathrm{C} 15 \mathrm{~s}\end{array}$ \\
\hline $\begin{array}{l}\text { Bacteria } 16 \mathrm{~S} \\
\text { rRNA }\end{array}$ & $\begin{array}{l}\text { 16S 341-F/ CCTACGGGAGGCAGCAG } \\
\text { 16S 515-R/ATTCCGCGGCTGGCA } \\
\text { (López-Gutiérrez et al. 2004) }\end{array}$ & $\begin{array}{l}95^{\circ} \mathrm{C} 10 \mathrm{~min} ; 40 \text { cycles: } 95^{\circ} \mathrm{C} 15 \mathrm{~s}, \\
60^{\circ} \mathrm{C} 30 \mathrm{~s}, 72^{\circ} \mathrm{C} 30 \mathrm{~s}, 80^{\circ} \mathrm{C} 30 \mathrm{~s},\end{array}$ \\
\hline
\end{tabular}

A melting curve analysis was performed after each assay to ensure that only the products of the desired melting temperature were generated from the SYBR Green qPCR. The $\mathrm{R}^{2}$ values for the standard curves were 0.99 or higher in all runs. The standard curves for quantifying gene copy numbers were determined by cloning the PCR products in a plasmid using the procedures reported by Okano et al. (2004). 


\subsubsection{Experiment 3: Post re-wetting soil $\mathrm{N}_{2} \mathrm{O}$ emissions}

\subsubsection{Samples collection}

Soil samples were collected from all plots at the end of summer fallow when the soil had minimum soil moisture content (below $2 \%$ of gravimetric soil moisture). A composite sample consisting of ten subsamples was collected from 0-10 cm soil layer from each field plot. Soil was transported to the laboratory and was air-dried during few days at room temperature to ensure the total drying. Although soil manipulation can affect soil biological activity, soil sieving $(<2 \mathrm{~mm})$ was preferred due to high amount of rock fragments $(51 \%)$. A total of 18 subsamples of homogenized sieved soil (20 g) were weighted on Petri dishes: half of them were wetted to 50\% of Field Capacity (FC) and the other half to $100 \%$ of FC. Petri dishes with moist soil were placed inside of the airtight jars (1.096 L volume) and incubated at $25^{\circ} \mathrm{C}$ in dark. One dish with each moisture level was used for GHG measurements while the other were destructively sampled $2 \mathrm{~h}$, $24 \mathrm{~h}, 4,7,11,14,20$ and 27 days after the establishement of the experiment. The petri dishes were weighted periodically to calculate the soil moisture.

\subsubsection{Laboratory analysis}

Greenhouse gases measurements: Immediately after the establishment, the jars were closed for two hours and gas samples were collected $\left(\mathrm{t}_{2 \mathrm{~h}}\right)$. Jars were ventilated and closed again for additional 20 hours to collected samples emitted between two hours since enclosure and 24 hours after closing the jars $\left(\mathrm{t}_{24 \mathrm{~h}}\right)$. The procedure was repeated to measure the emissions between 24 hours and 48 hours ( $\mathrm{t}_{48 \mathrm{~h}}$ ). Jars were then left with the valve open for the gas exchange and then closed again for $24 \mathrm{~h}$ periods after $4,711,14$, 20 and 27 days since the establishment of the experiment. Sampling after each incubation period was performed collecting $25 \mathrm{~mL}$ of headspace gas with a syringe and immediately transferred into pre-evacuated $12 \mathrm{ml}$ glass Exetainer ${ }^{\circledR}$ vials (Labco Ltd., Buckinghamshire, UK) with a septa screw cap into. At each sampling date, empty jars were incubated as blanks to remove the background noise of the atmospheric $\mathrm{N}_{2} \mathrm{O}$ in the laboratory. Concentrations of $\mathrm{N}_{2} \mathrm{O}$ were analyzed using a GC-2014 gas chromatograph (Shimadzu Scientific) with a 63Ni electron capture detector.

Nucleic acids extraction: Soil RNA was extracted from two grams g of fresh soil samples collected at $t_{2 h}$ and $t_{24 h}$ using RNeasy ${ }^{\circledR}$ PowerSoil $^{\circledR}$ Total RNA Kit (Quiagen $\mathrm{GmbH}$, Hilden, Germany) according to manufacturer's instructions. After the isolation of RNA, soil DNA was eluted using the RNeasy ${ }^{\circledR}$ PowerSoil $^{\circledR}$ DNA Elution Kit 
(Quiagen). DNA and RNA quality was verified by agarose gel electrophoresis (1\% $w / v)$. DNA extracts were quantified by comparison to bacteriophage $\lambda$ DNA dilutions (200, 100, $50 \mathrm{ng}$ ) using the Chemidoc XRS Apparatus (BioRad, Hercules, CA, USA) prior dilution of DNA extracts to $5 \mathrm{ng} \mu \mathrm{l}^{-1}$.

DNase treatment and reverse transcription PCR: Soil RNA was treated with DNase (Promega Corporation, Madison, WI, USA) in order to eliminate all DNA traces. An $22 \mu 1$ aliquot of RNA extract, $2 \mu 1$ of RNA-free water, $3 \mu l$ of buffer and $3 \mu 1$ of RQ1 RNase-free DNase (Promega Corporation, Madison, WI, USA) were incubated at $37^{\circ} \mathrm{C}$ for $30 \mathrm{~min}$. Afterwards, $3 \mu \mathrm{l}$ of RQ1 DNase Stop Solution (Promega) were added to stop the reaction. The DNase was then deactivated by the incubation at $65^{\circ} \mathrm{C}$ for 10 min. After DNase treatment, the samples were amplied and then, theabsence of DNA was checked by electrophoresis and in case of the presence of the band, the DNase treatment was repeated until a complete elimination of DNA from RNA extracts. All the incubations were run on MJ Research PTC-200 ${ }^{\mathrm{TM}}$ thermocycler (BioRad).

The DNA-free RNA was then converted to cDNA by using ImProm-II ${ }^{\mathrm{TM}}$ Reverse Transcriptase System (Promega). A $18 \mu \mathrm{l}$ aliquot of the RNA extracts were heated with $2 \mu \mathrm{l}$ of random primers (Promega) at $70^{\circ} \mathrm{C}$ for $5 \mathrm{~min}$ to remove secondary structures, and immediately placed on ice. Then, $20 \mu 1$ of reverse transcriptase (RT) mix was added to each of the RNA extracts for the RT reaction in thermocycler heated to for 5 min to $25^{\circ} \mathrm{C}$, one hour to $42^{\circ} \mathrm{C}$ and $15 \mathrm{~min}$ to $70^{\circ} \mathrm{C}$. The RT mix consisted of $4 \mu \mathrm{l}$ of buffer, $1.5 \mu \mathrm{l}$ of $\mathrm{MgCl}_{2}, 1 \mu \mathrm{l}$ of deoxynucleotid triphosphate (dNTP), $0.5 \mu \mathrm{l}$ of RNasin (Promega), $1 \mu \mathrm{l}$ of RT enzyme (Promega) and $2 \mu \mathrm{l}$ of water for each RNA sample. Negative controls were included where RNA extracts were substituted by water.

Real-time PCR quantification: The abundance of the key functional genes involved in nitrogen cycling (AOA-amoA, AOB-amoA, nirK, nirS, nosZ) in the DNA of initial soil samples and in cDNA were assessed by real time PCR (qPCR). The PCR was performed in $10 \mu 1$ reaction mixture containing the following components: $5 \mu 1$ of SsoAdvanced ${ }^{\mathrm{TM}}$ Universal SYBR ${ }^{\circledR}$ Green Supermix (BioRad), $0.5 \mu 1$ of each primer (Supplementary Material Table S-2) and $4 \mu 1$ of diluted DNA or cDNA extracts.

Any reaction inhibition by co-extracted humic compounds was compensated by optimal dilution of DNA extracts (data not shown). The qPCR assays were run on MJ Research PTC-200 ${ }^{\mathrm{TM}}$ Peltier Thermal Cycler coupled with Chromo4 continuous 
Fluorescence Detector (BioRad). The initial denaturation step of $95^{\circ} \mathrm{C}$ for 10 min was common for all runs and the amplification cycles were specific to each target gene as listed in Table 3.2.5. Negative control and standard curve were run in each plate. All samples and standards were run in triplicate. Data output were released by Opticon Monitor software (version 2.03 MJ Research). For absolute quantification, standard curves were prepared using purified plasmids of known concentrations.

Denaturation gradient gel electrophoresis (DGGE) analysis: Amplification reactions of target genes was run on MJ Research PTC-200 ${ }^{\mathrm{TM}}$ thermocycler (BioRad) in a $25-\mu 1$ mixture containing $2 \mu \mathrm{l}$ template DNA, $1.5 \mathrm{mmol} \mathrm{L}^{-1} \mathrm{MgCl}_{2}, 200 \mu \mathrm{mol} \mathrm{L}^{-1}$ of

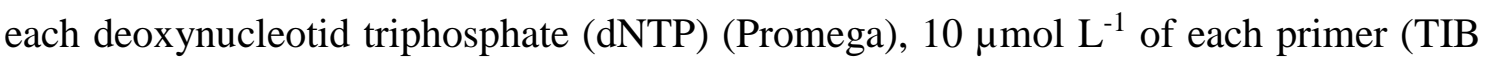
MolBiol), $1 \mu \mathrm{mol} \mathrm{L} \mathrm{L}^{-1} \mathrm{x}$ green $\mathrm{GoTaq}^{\circledR}$ polymerase (Promega), as described by Lagomarsino et al. (2016). The reaction conditions are listed in Table 3.2.6. The Chemidoc XRS Apparatus (BioRad) was used for the comparison of amplified DNA with Low DNA mass ladder (Invitrogen, Carlsbad, CA, USA) in order to assess the amplicons yields.

Table 3.2.5: Target genes, used primers and qPCR conditions

\begin{tabular}{|c|c|c|}
\hline Target gene & $\begin{array}{l}\text { Primers / Sequence }\left(5^{\prime}-3^{\prime}\right) \\
\text { (reference) }\end{array}$ & qPCR \\
\hline AOB-amoA & $\begin{array}{l}\text { amoA-F/ GGGGTTTCTACTGGTGGT } \\
\text { amoA -R/ CCCCTCKGSAAAGCCTTCTTC } \\
\text { (Rotthauwe et al. 1997) }\end{array}$ & $\begin{array}{l}95^{\circ} \mathrm{C} 10 \mathrm{~min} ; 40 \text { cycles: } 95^{\circ} \mathrm{C} 45 \mathrm{~s}, \\
58^{\circ} \mathrm{C} 45 \mathrm{~s}, 72^{\circ} \mathrm{C} 45 \mathrm{~s}\end{array}$ \\
\hline AOA- $а т о A$ & $\begin{array}{l}\text { amoArs-F/ STAATGGTCTGGCTTAGACG } \\
\text { amoArs-R/ GCGGCCATCCATCTGTATGT } \\
\text { (Francis et al. 2005) }\end{array}$ & $\begin{array}{l}95^{\circ} \mathrm{C} 10 \mathrm{~min} ; 40 \text { cycles: } 95^{\circ} \mathrm{C} 45 \mathrm{~s}, \\
55^{\circ} \mathrm{C} 45 \mathrm{~s}, 72^{\circ} \mathrm{C} 45 \mathrm{~s}\end{array}$ \\
\hline nirK & $\begin{array}{l}\text { nirK-F/ ATYGGCGGVCAYGGCGA } \\
\text { nirK-R/ GCCTCGATCAGRTTRTGGTT } \\
\text { (Henry et al. 2004) }\end{array}$ & $\begin{array}{l}95^{\circ} \mathrm{C} 10 \mathrm{~min} ; 95^{\circ} \mathrm{C} 15 \mathrm{~s}, 63 \text { to } 58^{\circ} \mathrm{C} \\
30 \mathrm{~s}\left(-1^{\circ} \mathrm{C} \text { by cycle }\right), 72^{\circ} \mathrm{C} 30 \mathrm{~s}, 80^{\circ} \mathrm{C} \\
15 \mathrm{~s}(6 \text { cycles }) ; 40 \text { cycles: } 95^{\circ} \mathrm{C} 15 \mathrm{~s} \text {, } \\
60^{\circ} \mathrm{C} 30 \mathrm{~s}, 72^{\circ} \mathrm{C} 30 \mathrm{~s}, 80^{\circ} \mathrm{C} 15 \mathrm{~s} .\end{array}$ \\
\hline nirS & $\begin{array}{c}\text { nirSCd3aF-F/ AACGGYSAAGGRACSGG } \\
\text { nirSR3Cd-R/ GASTTCGGRTGSGTCTTSAYGAA } \\
\text { (Henry et al. } 2004\end{array}$ & $\begin{array}{l}95^{\circ} \mathrm{C} 15 \mathrm{~min} ; 95^{\circ} \mathrm{C} 15 \mathrm{~s}, 65 \text { to } 60^{\circ} \mathrm{C} \\
30 \mathrm{~s}\left(-1^{\circ} \mathrm{C} \text { by cycle }\right), 72^{\circ} \mathrm{C} 30 \mathrm{~s}, 80^{\circ} \mathrm{C} \\
15 \mathrm{~s}(6 \text { cycles }) ; 40 \text { cycles: } 95^{\circ} \mathrm{C} 15 \mathrm{~s} \text {, } \\
60^{\circ} \mathrm{C} 30 \mathrm{~s}, 72^{\circ} \mathrm{C} 30 \mathrm{~s}, 80^{\circ} \mathrm{C} 15 \mathrm{~s} .\end{array}$ \\
\hline nosZ & $\begin{array}{c}\text { nosZ1840F/ CGCRACGGCAASAAGGTSMSSGT } \\
\text { nosZ2090R/ CAKRTGCAKSGCRTGGACGAA } \\
\text { (Henry et al. 2006) }\end{array}$ & $\begin{array}{l}95^{\circ} \mathrm{C} 15 \mathrm{~min} ; 6 \text { cycles: } 95^{\circ} \mathrm{C} 15 \mathrm{~s} \text {, } \\
65^{\circ} \mathrm{C} 30 \mathrm{~s}, 72^{\circ} \mathrm{C} 30 \mathrm{~s}, 80^{\circ} \mathrm{C} 15 \mathrm{~s}(6 \\
\text { cycles) } 40 \text { cycles: } 95^{\circ} \mathrm{C} 15 \mathrm{~s}, 60^{\circ} \mathrm{C} \\
15 \mathrm{~s}, 72^{\circ} \mathrm{C} 30 \mathrm{~s}, 80^{\circ} \mathrm{C} 15 \mathrm{~s} \text {; and } 1 \mathrm{cycle} \\
\text { at } 95^{\circ} \mathrm{C} 15 \mathrm{~s}, 60^{\circ} \mathrm{C} 15 \mathrm{~s} \text { and } 95^{\circ} \mathrm{C} 15 \mathrm{~s} \text {. }\end{array}$ \\
\hline
\end{tabular}


The DGGE analyses were performed by loading $500 \mathrm{ng}$ of amplicons onto a polyacrylamide gel (acrylamide/bis 37.5:1; Euroclone S.p.A, Pero, Italy), with a linear denaturating gradients obtained with a $100 \%$ denaturant solution consisting of $40 \% \mathrm{v} / \mathrm{v}$ formamide (Euroclone S.p.A, Pero, Italy) and 7M urea (Euroclone S.p.A, Pero, Italy) as described in Lagomarsino et al. (2016). The gels were run for at least $17 \mathrm{~h}$ in $1 \mathrm{X}$ TAE buffer in the DCode ${ }^{\mathrm{TM}}$ System (BioRad). The voltage and temperature were constant during the run at $80 \mathrm{~V}$ and $60{ }^{\circ} \mathrm{C}$, respectively. The gels were then stained with SYBR $^{\circledR}$ GOLD (Invitrogen, Carlsbad, CA, USA) diluted 1:1000 in 1X TAE. The images of the gel were digitalized using the Chemidoc XRS Apparatus (BioRad).

Table 3.2.6: PCR primers and annealing temperatures used for DGGE analysis

\begin{tabular}{|c|c|c|c|}
\hline \multirow[t]{2}{*}{ Target gene } & \multicolumn{2}{|l|}{ PCR conditions } & \multirow[t]{2}{*}{ Reference } \\
\hline & Primer & Annealing & \\
\hline amoA Bacteria & aamoA1F, amoA2R & $57^{\circ} \mathrm{C}$ & (Xu et al. 2012) \\
\hline amoA Archea & Arch-amoAF, ${ }^{a}$ Arch-amoAR & $55^{\circ} \mathrm{C}$ & (Xu et al. 2012) \\
\hline nirK Bacteria & $\mathrm{F} 1 \mathrm{aCu},{ }^{\mathrm{a}} \mathrm{R} 3 \mathrm{Cu}$ & $57^{\circ} \mathrm{C}$ & (Throbäck et al. 2004) \\
\hline nirS & $\mathrm{Cd} 3 \mathrm{AF},{ }^{\mathrm{a}} \mathrm{R} 3 \mathrm{Cd}$ & $52{ }^{\circ} \mathrm{C}$ & (Throbäck et al. 2004) \\
\hline nosZ & $\operatorname{nosZF},{ }^{\mathrm{a}} 1773 \mathrm{~b}$ & $58^{\circ} \mathrm{C}$ & (Scala and Kerkhof 1998) \\
\hline
\end{tabular}

${ }^{a}$ A GC-clamp was added for DGGE analysis

Initial soil properties: The initial $\mathrm{SOC}$ and total $\mathrm{TN}$ were determined by automatic analyzer LECO Instrument TruSpec CN (LECO Corporation, St. Joseph, MI, USA). The soil $\mathrm{pH}$ in $\mathrm{H}_{2} \mathrm{O}$ was determined at a ratio 1:2.5; w:v. The $\mathrm{FC}$ of sieved soil $(<2 \mathrm{~mm})$ was determined at a matric potential of $-33 \mathrm{kPa}$ in a pressure plate extractor (Soil Moisture Equipment Corp, Santa Barbara, CA, USA). The initial soil properties are summarized in Table 3.2.7.

Table 3.2.7: Initial properties of the soil used for the rewetting experiment

\begin{tabular}{|c|c|c|c|c|}
\hline & SOC & $\mathrm{TN}$ & $\mathrm{pH}$ & \multirow{2}{*}{$\begin{array}{l}\mathrm{FC} \\
(\%)\end{array}$} \\
\hline & \multicolumn{2}{|l|}{$(\%)$} & & \\
\hline TT-A & 3.42 & 0.18 & 5.57 & 14.4 \\
\hline NT-A & 3.89 & 0.21 & 5.41 & 15.8 \\
\hline $\mathrm{TT}$ & 3.31 & 0.17 & 4.15 & 14.7 \\
\hline NT & 3.78 & 0.20 & 4.36 & 15.7 \\
\hline
\end{tabular}

SOC, total organic carbon; TN, total nitrogen; FC, Field Capacity

TT-A traditional tillage with liming amendment; NT-A no tillage with liming amendment; TT traditional tillage without liming amendment; NT no tillage without liming amendment. 


\subsubsection{Statistical analysis}

Data of DNA quantification in initial soil samples were analyzed statistically using a linear mixed model (LMM) using SPSS 22 (IBM SPSS INC., Chicago, USA). The tillage and the application of liming amendment were considered fixed factors while the experimental field blocks $(n=4)$ were consider random factors. Similarly, the cDNA quantification of incubated soils and the $\mathrm{N}_{2} \mathrm{O}$ cumulative emission were analyzed using a LMM including the moisture level, tillage and amendment as fixed factor while each field block was considered a random factor. Additionally, another LMM including also the sampling date was performed to evaluate the $\mathrm{N}_{2} \mathrm{O}$ emission rates and cDNA quantification. In this study, a LSD test $(\mathrm{p}<0.05)$ was used to test the differences between the different sampling dates.

Evaluation of band migration distance and intensity within each DGGE profiles was carried out using GelCompar II v.46 (Applied Maths, Sint-Martens-Latem, Belgium). Species richness of each soil was determined by counting the number of bands per sample and the Shannon-Weiner diversity index was calculated according to Pastorelli et al. (2011). The effect of treatments on richness and Shannon-Weiner diversity index was analyzed by two-way ANOVA with tillage and liming and their interaction as factors. The similarity among the communities of the different soils was determined by pairwise comparison of the position and presence/absence of bands in the different DGGE profiles. A matrix containing similarity values was obtained applying the Dice coefficient and the Unweighted-Pair Group Method using Arithmetic average (UPGMA) algorithm was applied to build a dendrogram based of the obtained matrix. After that, the banding patterns of each DGGE were imported to PAST software (Hammer et al. 2001) to perform a Non-metric multidimensional scaling (nMDS) representation to visualize differences between each soil sample in a bi-dimensional space. The accuracy of the nMDS was evaluated based on the 2D stress. The statistical significance of the different treatments on DGGE profiles was evaluated using two-way analysis of similarity (ANOSIM) and permutational multivariate analysis of variance (PERMANOVA) in PAST software. nMDS, ANOSIM, and PERMANOVA were performed using the Dice coefficient and 9,999 permutational tests. 


\subsubsection{Experiment 4: Effects of NT \& liming on carbon and nitrogen mineralization}

\subsubsection{Samples collection}

In October 2015, ten years after the field experiment establishment, samples composed of four subsamples were collected from two depths $(0-5$ and 5-10 cm) in each experimental plot (four field replicates per treatment). In total, 32 samples were collected. These samples correspond to the last sampling described in the EXPERIMENT 1. Samples were transported to the laboratory and sieved $(<2 \mathrm{~mm})$ on the same day.

\subsubsection{Laboratory analysis}

Soil incubation set-up: For C mineralization experiment, field moist soil in amount equivalent to 30 grams of dry weight were placed in $0.5 \mathrm{~L}$ plastic jars for aerobic incubation $\left(60 \%\right.$ field capacity, $25^{\circ} \mathrm{C}$ ), using $\mathrm{NaOH}$ as an alkaline trap (Iannotti et al. 1993). The trap was titrated every 2-5 days with $\mathrm{HCl}$ after precipitation of carbonates with $\mathrm{BaCl}_{2}$. In another set of jars, field moist soil equivalent to 100 grams of dry weight were incubated under same conditions to monitor the $\mathrm{N}$ mineralization. Subsamples were taken periodically for analysis of $\mathrm{NH}_{4}{ }^{+}-\mathrm{N}$ and $\mathrm{NO}_{3}{ }^{-} \mathrm{N}$ which were determined colorimetrically using procedures cited in Teutscherova et al. (2017).

Carbon and nitrogen mineralization: Cumulative $\mathrm{CO}_{2}$ production during the incubation (70 days) was fitted to non-linear equation and potentially mineralizable fraction of $\mathrm{C}$ and mineralization rates were determined by the first order kinetic model:

$\mathrm{C}_{\mathrm{m}}=\mathrm{C}_{\mathrm{o}}\left(1-\mathrm{e}^{-k t}\right)$

where $\mathrm{C}_{\mathrm{m}}$ is the $\mathrm{C}\left(\mathrm{mg} \mathrm{CO} \mathrm{CO}_{2}-\mathrm{Cg}^{-1}\right)$ mineralized at time $t$ (days ), $\mathrm{C}_{\mathrm{o}}$ the potentially mineralizable $\mathrm{C}\left(\mathrm{mg} \mathrm{CO}_{2}-\mathrm{C} \mathrm{kg}^{-1}\right)$ and $k$ the $\mathrm{C}$ mineralization rate constant. In addition, $C_{o} k$, initial potential mineralization rate, was calculated.

Net nitrogen mineralization $(\mathrm{NNM})$ and net nitrification $(\mathrm{NN})$ were calculated according to Hart et al. (1994):

$\mathrm{NNM}\left(\mu \mathrm{g} \mathrm{N} \mathrm{g}^{-1} \mathrm{~d}^{-1}\right)=\left[\left(\mathrm{NH}_{4}{ }^{+}-\mathrm{N}_{\text {final }}+\mathrm{NO}_{3}{ }^{-}-\mathrm{N}_{\text {final }}\right)-\left(\mathrm{NH}_{4}{ }^{+}-\mathrm{N}_{\text {initial }}+\mathrm{NO}_{3}{ }^{-}-\mathrm{N}_{\text {initial }}\right)\right] /$ days of incubation 
$\mathrm{NN}\left(\mu \mathrm{g} \mathrm{NO}_{3}{ }^{-}-\mathrm{N} \mathrm{g}^{-1} \mathrm{~d}^{-1}\right)=\left(\mathrm{NO}_{3}{ }^{-}-\mathrm{N}_{\text {final }}-\mathrm{NO}_{3}{ }^{-}-\mathrm{N}_{\text {initial }}\right) /$ days of incubation

Soil chemical properties: Soil pH was determined in $\mathrm{H}_{2} \mathrm{O}$ and $\mathrm{KCl} 1 \mathrm{M}$ (1:2.5; w:v). The amount of exchangeable $\mathrm{Ca}$ and $\mathrm{Mg}$ was determined by soil extraction with ammonium acetate $(\mathrm{pH}$ 7) followed by elemental analysis by atomic absorption spectrophotometry (AAnalyst 400, PerkinElmer, Wellesley, MA). The SOM content was determined as a loss of ignition (Nelson et al. 1996). The SOC and TN were analyzed by automatic analyzer LECO Instrument TruSpec CN (LECO Corporation, St. Joseph, MI, USA). The method of Cambardella and Elliott (1992) was used for particulate organic matter (POM) isolation and $\mathrm{POxC}$ was quantified with the method proposed by Weil et al. (2003).

Microbial biomass and enzymatic activities: The MBC and MBN and the EAs which were used to calculate the geometric mean of the assayed enzyme activities (Gmean) correspond to the samples collected in October presented in EXPERIMENT 1. The Gmean was calculated according to Hinojosa et al. (2004) using all the enzymatic activities expressed in dry-weight basis as:

Gmean $=(\beta$-glucosidase $* \beta$-glucosaminidase*acid phosphomonoesterase $*$ arylsulphatase* Urease* dehydrogenase $)^{1 / 6}$

The abundance of soil bacteria and fungi: Soil DNA was extracted from $0.25 \mathrm{~g}$ of fresh soil using a PowerSoil DNA isolation kit (MoBIO Laboratories, Carlsbad, CA, USA). The abundance of 16S rRNA gene for total bacteria and ITS for total fungi was quantified by the quantitative PCR (qPCR) using ABI Real Time 7300 sequence detection system (Applied Biosystems, Waltham, MA, USA). The qPCR conditions and the gene sequences are listed in Table 3.2.8. The ratio between the abundance of total fungi and total bacteria $(\mathrm{F}: \mathrm{B})$ was calculated as the ratio of gene copies expressed in number of copies per gram of dry soil. DNA concentration and purity were determined by $260 / 280 \mathrm{~nm}$ and 260/230 $\mathrm{nm}$ measurements using a Nanodrop spectrophotometer (DeNovix, Wilmington, DE, USA). 
Table 3.2.8: Target genes, used primers and qPCR conditions

\begin{tabular}{|c|c|c|}
\hline Target gene & $\begin{array}{c}\text { Primers / Sequence }\left(5^{\prime}-3^{\prime}\right) \\
\text { (reference) }\end{array}$ & qPCR \\
\hline ITS & $\begin{array}{c}\text { ITS5-F /GGAAGTAAAACTCCGTAACAAGG } \\
\text { ITS4-R/TCCTCCGTCTATTGATATGC } \\
\text { (Schoch et al. 2012) }\end{array}$ & $\begin{array}{l}50^{\circ} \mathrm{C}, 2 \mathrm{~min} ; 95^{\circ} \mathrm{C} 5 \mathrm{~m} ; 1 \\
\text { cycle: } 95^{\circ} \mathrm{C} 1 \mathrm{~m}, 55^{\circ} \mathrm{C} 1 \mathrm{~m}, \\
72^{\circ} \mathrm{C} 45 \mathrm{~s}, 45 \text { cycles: } 95^{\circ} \mathrm{C} \\
15 \mathrm{~s}, 60^{\circ} \mathrm{C} 30 \mathrm{~s}, 95^{\circ} \mathrm{C} 15 \mathrm{~s}\end{array}$ \\
\hline $\begin{array}{l}\text { Bacteria } \\
\text { rRNA }\end{array}$ & $\begin{array}{c}\text { 16S 341-F/ CCTACGGGAGGCAGCAG } \\
\text { 16S 515-R/ATTCCGCGGCTGGCA } \\
\text { (López-Gutiérrez et al. 2004) }\end{array}$ & $\begin{array}{l}95^{\circ} \mathrm{C} 10 \mathrm{~min} ; 40 \text { cycles: } \\
95^{\circ} \mathrm{C} 15 \mathrm{~s}, \\
60^{\circ} \mathrm{C} 30 \mathrm{~s}, 72^{\circ} \mathrm{C} 30 \mathrm{~s}, 80^{\circ} \mathrm{C} \\
30 \mathrm{~s},\end{array}$ \\
\hline
\end{tabular}

A melting curve analysis was performed after each assay to ensure that only the products of the desired melting temperature were generated from the SYBR Green qPCR. The $\mathrm{R}^{2}$ values for the standard curves were 0.99 or higher in all runs. The standard curves for quantifying gene copy numbers were determined by cloning the PCR products in a plasmid using the procedures reported by Okano et al. (2004).

\subsubsection{Statistical analysis}

Data were analyzed statistically with a LMM using the SPSS 22 software (IBM SPSS, Inc., Chicago, USA). The sampling depth (Dpt), soil tillage (T) and the amendment (A) were used as fixed factors, while the plot $(n=16)$ was used as a random factor. The correlation between variables was evaluated using the Pearson coefficient test (Table S-3). Structural equation modeling (SEM) was performed using AMOS 25.0 (Amos Development, Spring House, Pennsylvania, USA) to analyze the hypothetical direct and indirect pathways by which the type of tillage and liming amendment affects $\mathrm{C}$ and $\mathrm{N}$ mineralization. Previous studies have demonstrated the usefulness of SEM to evaluate the effects of different agricultural practices on the $\mathrm{C}$ cycle and microbial activity using SEM (Zhang et al. 2013, 2018; Crittenden and de Goede 2016) where the number of samples was lower than the recommended to perform powerfully a SEM (5 to 1 samples per parameter) (Eisenhauer et al. 2015), which, however, seems to be unrealistic in agronomic experimental plots. However, the experimental origin of the data generates highly correlated parameters without missing data which lead to well fitted models (Zhang et al. 2013, 2018; Crittenden and de Goede 2016).

The latent variables are conceptual variables (and unmeasurable) defined by other measured variables which represent the effects of this latent variable (Eisenhauer et al. 2015). This is for example the case of soil process which are not directly measured but can be estimated by mean of microbial indicadors or enzymatic activities (Eisenhauer et al. 2015; Williams et al. 2017). 


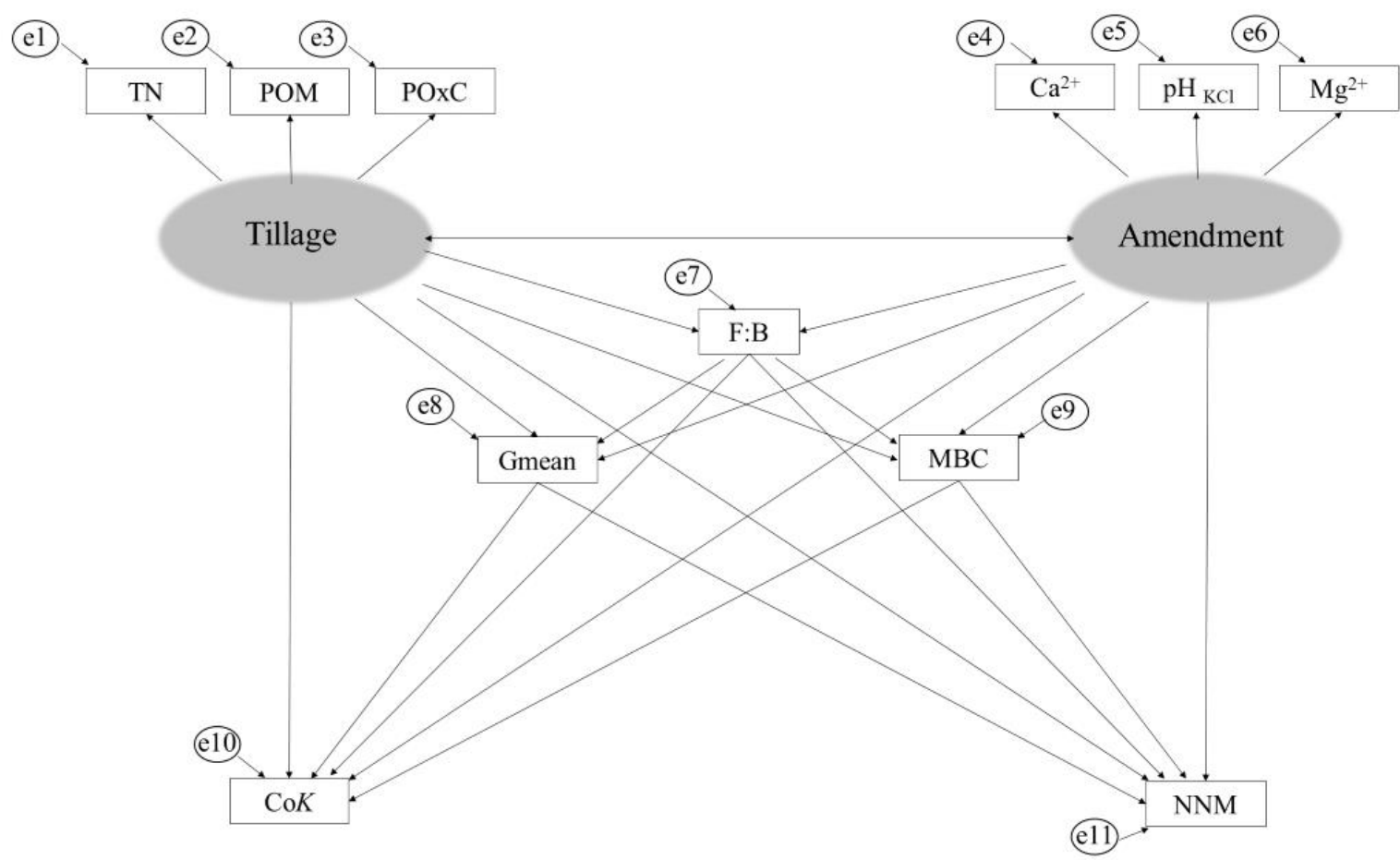

Fig. 3.2.4: A priori SEM of the hypothesized relationships between Tillage practices and the Amendment application and soil $\mathrm{C}$ and $\mathrm{N}$ mineralization and net nitrification. The endogenous variables are represented into squares and the latent variables are represented into circles. TN, total nitrogen; POM, particulate organic matter; POxC, permanganate organizable carbon; Gmean, geometric mean of enzymatic activities; F:B, fungi-to-bacteria ratio; $\mathrm{MBC}$, microbial bioamass carbon; $\mathrm{CoK}$, initial potential $\mathrm{C}$ mineralization rate; NNM, net nitrogen mineralization.

In our case, the presence/absence of tillage and the liming amendment were considered latent variables (Tillage and Amendment, respectively) defined by other measured chemical variables which were theoretically affected by the different treatments. These variables were selected after testing statistically the effect of soil tillage or amendment on them. When several chemical parameters were affected by one of the factors, three were selected according to the higher correlation of the parameters with the $\mathrm{C}$ and $\mathrm{N}$ mineralization (Table 3.2.9). In the a priori model (Fig. 3.2.4), it was stipulated that Tillage and Amendment can influence the $\mathrm{C}$ and $\mathrm{N}$ mineralization $\left(C_{o} K\right.$ and NNM, respectively) either directly via changes in the soil chemical properties or indirectly via multiple changes in the microbial population and activity. Previous studies using SEM have demonstrated the usefulness of the inclusion of the size of microbial biomass and the structure or the activity of soil microorganisms to understand the $\mathrm{C}$ and $\mathrm{N}$ mineralization process (Colman and Schimel 2013; Fanin and Bertrand 2016; Heijboer et al. 2016; Pommier et al. 2018). The selected microbial parameters 
were the MBC, Gmean and F:B ratio in order to represent the changes in the size of the microbial biomass, the potential mineralization activity and the changes in the microbial community structure, respectively. We tested the multivariate normality of data using the Mardia's multivariate normality test. Data were fitted to the model applying the maximum likelihood estimation method. Adequacy of models was determined by using $\chi^{2}$ test $(\mathrm{P}<0.05)$, the comparative fit index $(\mathrm{CFI})$, the root mean square of approximation (RMSEA), the standardized root mean square residual (SRMR) and Akaike's Information criteria (AIC) (Hooper et al. 2008). Once the model consistence was achieved, we evaluated alternative models where predictors variables and nonsignificant pathways were removed in order to achieve more parsimonious model with the data (Colman and Schimel 2013). The selection of the alternative model was based on AIC values. Although no non-significant pathways were deleted, the Amendment finally was only defined by two measured variables $\left(\mathrm{Ca}^{2+}\right.$ and $\left.\mathrm{pH} \mathrm{KCl}\right)$. 
Table 3.2.9: Correlation matrix of the chemical and biological parameters determined in the study. The top part of the matrix indicates correlation coefficients and the bottom part the level of significance.

\begin{tabular}{|c|c|c|c|c|c|c|c|c|c|c|c|c|c|c|c|c|}
\hline I & $C_{o} K$ & NNM & $\mathrm{NN}$ & TOC & $\mathrm{TN}$ & $\mathrm{SOM}$ & POM & POxC & $\mathrm{pH}_{\mathrm{H} 2 \mathrm{O}}$ & $\mathrm{pH}_{\mathrm{KCl}}$ & $\mathrm{Ca}^{2+}$ & $\mathrm{Mg}^{2+}$ & $\mathrm{MBC}$ & $\mathrm{MBN}$ & Gmean & $\mathrm{F}: \mathrm{B}$ \\
\hline$C_{o} K$ & - & 0.839 & 0.856 & 0.686 & 0.786 & 0.564 & 0.861 & 0.752 & 0.430 & 0.462 & 0.530 & 0.793 & 0.726 & 0.764 & 0.826 & -0.622 \\
\hline NNM & $* *$ & - & 0.998 & 0.644 & 0.746 & 0.537 & 0.806 & 0.757 & 0.514 & 0.581 & 0.648 & 0.807 & 0.606 & 0.704 & 0.825 & -0.624 \\
\hline $\mathrm{NN}$ & $* *$ & $* *$ & - & 0.669 & 0.766 & 0.566 & 0.823 & 0.772 & 0.500 & 0.562 & 0.631 & 0.814 & 0.628 & 0.715 & 0.834 & -0.630 \\
\hline TOC & $* *$ & $* *$ & $* *$ & - & 0.968 & 0.906 & 0.881 & 0.839 & 0.310 & 0.340 & 0.428 & 0.711 & 0.658 & 0.578 & 0.790 & -0.390 \\
\hline $\mathrm{TN}$ & $* *$ & $* *$ & $* *$ & $* *$ & - & 0.878 & 0.937 & 0.899 & 0.379 & 0.407 & 0.503 & 0.781 & 0.691 & 0.669 & 0.864 & -0.482 \\
\hline SOM & $* *$ & $* *$ & $* *$ & $* *$ & $* *$ & - & 0.809 & 0.744 & 0.291 & 0.287 & 0.356 & 0.593 & 0.539 & 0.416 & 0.667 & -0.225 \\
\hline POM & $* *$ & $* *$ & $* *$ & $* *$ & $* *$ & $* *$ & - & 0.903 & 0.371 & 0.412 & 0.545 & 0.849 & 0.729 & 0.719 & 0.906 & -0.579 \\
\hline $\mathrm{POxC}$ & $* *$ & $* *$ & $* *$ & $* *$ & $* *$ & $* *$ & $* *$ & - & 0.401 & 0.418 & 0.559 & 0.824 & 0.632 & 0.775 & 0.897 & -0.588 \\
\hline $\mathrm{pH}_{\mathrm{H} 2 \mathrm{O}}$ & $*$ & $* *$ & $* *$ & n.s. & $*$ & n.s. & $*$ & $*$ & - & 0.968 & 0.880 & 0.604 & -0.058 & 0.394 & 0.608 & -0.215 \\
\hline $\mathrm{pH}_{\mathrm{KCl}}$ & $* *$ & $* *$ & $* *$ & n.s. & $*$ & n.s. & $*$ & $*$ & $* *$ & - & 0.916 & 0.628 & -0.034 & 0.426 & 0.650 & -0.297 \\
\hline $\mathrm{Ca}^{2+}$ & $* *$ & $* *$ & $* *$ & $*$ & $* *$ & $*$ & $* *$ & $* *$ & $* *$ & $* *$ & - & 0.763 & 0.013 & 0.467 & 0.768 & -0.356 \\
\hline $\mathrm{Mg}^{2+}$ & $* *$ & $* *$ & $* *$ & $* *$ & $* *$ & $* *$ & $* *$ & $* *$ & $* *$ & $* *$ & $* *$ & - & 0.515 & 0.733 & 0.923 & -0.569 \\
\hline MBC & $* *$ & $* *$ & $* *$ & $* *$ & $* *$ & $* *$ & $* *$ & $* *$ & n.s. & n.s. & n.s. & $* *$ & - & 0.688 & 0.542 & -0.547 \\
\hline MBN & $* *$ & $* *$ & $* *$ & $* *$ & $* *$ & $*$ & $* *$ & $* *$ & $*$ & $*$ & $* *$ & $* *$ & $* *$ & - & 0.756 & -0.546 \\
\hline Gmean & $* *$ & $* *$ & $* *$ & $* *$ & $* *$ & $* *$ & $* *$ & $* *$ & $* *$ & $* *$ & $* *$ & $* *$ & $* *$ & $* *$ & - & -0.594 \\
\hline $\mathrm{F}: \mathrm{B}$ & $* *$ & $* *$ & $* *$ & $*$ & $* *$ & n.s. & $* *$ & $* *$ & n.s. & n.s. & $*$ & $* *$ & $* *$ & $* *$ & $* *$ & - \\
\hline
\end{tabular}

$C_{o} k$, initial potential $\mathrm{C}$ mineralization rate; NNM, net nitrogen mineralization; NN, net nitrification; TOC, soil total carbon; TN, total nitrogen; SOM, soil organic matter; POM, particulate organic matter; POxC, permanganate oxidizable carbon; MBC, microbial biomass C; MBN, microbial biomass $\mathrm{N}$; Gmean, geometric mean of the assayed enzymes; F:B, fungi-to-bacteria ratio

$* \mathrm{p}<0.05$, ** $\mathrm{p}<0.01$, n.s., no significant 


\subsubsection{Experiment 5: Effect of NT, liming and depth on soil proteases}

\subsubsection{Samples collection}

Soil samples were collected on the harvest day (31 $1^{\text {st }}$ of May in 2016) when the microbial activity was expected to be high (Vazquez et al. 2017). Samples were collected with the metal auger $(5 \mathrm{~cm}$ diameter) from three soil mineral layers $(0-5 \mathrm{~cm}$, 5-10 cm and 10-25 cm) after the removal of the crop litter and stubble if present. Three sub-samples were taken from each plot to form one composite sample per plot and depth. Soil was transported to the laboratory immediately after sampling and stored at $4^{\circ} \mathrm{C}$ until the analyses were conducted (within a week). An aliquot of each sample was air-dried for determination of soil chemical properties.

\subsubsection{Laboratory analysis}

Enzymatic activities: The activity of casein-hydrolyzing enzymes (hereafter, casein protease) and N-benzoyl-L-argininamide protease (hereafter, BAA protease) was performed according to methods proposed by Ladd and Butler (1972) and Nannipieri et al. (1980), respectively. The activity of $\beta$-glucosidase (Gls) was assessed following the method of Hoffmann and Dedeken (1965) modified by Strobl and Traunmueller (1996) using $\beta$-glucoso-saligenin (salicin) as a substrate. The ratio between casein and BAA protease activities was used as an estimate of relative production of intermediate protein products (e.g. monomers) and $\mathrm{NH}_{4}{ }^{+}$.

Microbial biomass and extractable $\mathbf{C}$ and $\mathbf{N}$ compounds: The MBC and MBN were determined using the fumigation-extraction method (Vance et al. 1987) by fumigating $15 \mathrm{~g}$ of soil with ethanol-free chloroform followed by $0.5 \mathrm{M} \mathrm{K}_{2} \mathrm{SO}_{4}$ extraction (w:v 1:4); additionally, $15 \mathrm{~g}$ of soil were extracted with $\mathrm{K}_{2} \mathrm{SO}_{4}$ without fumigation. The concentration of extracted organic $\mathrm{C}$ was determined colorimetrically by measuring $\mathrm{Cr}^{3+}$ at 578nm, (UV-1203, Shimadzu, Kyoto, Japan) produced by reduction of $\mathrm{Cr}^{6+}$ after microwave digestion (Speedwave four, Berghof, Eningen, Germany) at $135^{\circ} \mathrm{C}$ for 30 minutes. Extracted total $\mathrm{N}$ content was determined by Kjeldahl digestion of extracts followed by steam distillation (Bremner and Mulvaney 1982). Microbial biomass $C$ and MBN were calculated as the difference between the $C$ and $\mathrm{N}$ content in fumigated and non-fumigated samples, divided by 0.38 (Joergensen 1996b) and 0.54 (Brookes et al. 1985), respectively. The content of $\mathrm{C}$ and $\mathrm{N}$ in nonfumigated samples is referred to as DOC and $\mathrm{N}(\mathrm{EN})$, respectively. In the $\mathrm{K}_{2} \mathrm{SO}_{4}$ 
extracts of non-fumigated samples, the contents of carbohydrates (Carbex $)$ were assessed by using the method proposed by Safarik and Santruckova (1992).

Easily-extractable glomalin-related soil protein: The easily extractable glomalin-related soil protein (EE-GRSP) was extracted from $1 \mathrm{~g}$ of air-dried soil with 20 $\mathrm{mM}$ sodium citrate solution $(\mathrm{pH} 7.0)$ in autoclave $\left(121^{\circ} \mathrm{C}, 30 \mathrm{~min}\right)$ (Wright and Upadhyaya 1998) followed by protein quantification in the extract using the Bradford protein assay with bovine serum albumin as the standard. Only easily extractable GRSP was estimated as it is often found to be the most labile and reactive pool of total GRSP in soils (Gómez-Paccard et al., 2013). Laboratory analyses were performed in duplicates.

Soil chemical properties: The SOC and TN content were analysed by LECO Instrument TruSpec CN (LECO Corporation, St. Joseph, MI, USA). The potentially mineralizable N (PMN) content was assessed according to Waring and Bremner, (1964) by anaerobic 7-day incubation at $37{ }^{\circ} \mathrm{C}$ and subtracting the initial $\mathrm{NH}_{4}{ }^{+}-\mathrm{N}$ content from the amount of $\mathrm{NH}_{4}{ }^{+}-\mathrm{N}$ at the end of the incubation. $\mathrm{NH}_{4}{ }^{+}-\mathrm{N}$ was extracted with $2 \mathrm{M} \mathrm{KCl}$ (1:10) and was determined colorimetrically (UV-1203, Shimadzu, Kyoto, Japan) using the sodium salicylate method (Forster 1995).

Plant biomass production and foliar $\mathbf{C}$ and $\mathbf{N}$ content: Before soil sample collection, one square meter was randomly selected for the harvest the aboveground plant biomass. All standing biomass was cut at around $10 \mathrm{~cm}$ above the soil surface, packed in bags and transported to the laboratory where it was air-dried until constant weight $\left(70{ }^{\circ} \mathrm{C}\right)$. Dry biomass was homogenized and a subsample was used for quantification of total $\mathrm{C}$ and $\mathrm{N}$ content using a LECO Instrument TruSpec CN (LECO Corporation, St. Joseph, MI, USA).

\subsubsection{Statistical analysis}

Data were analyzed statistically with a LMM using the SPSS 22 software (IBM SPSS, Inc., Chicago, USA). The Liming application (A), soil tillage (T) and the sampling depth (Dpt) were used as fixed factors, while the plot $(\mathrm{n}=16)$ and the field block $(n=4)$ were considered as random factors. To analyze the correlations between variables, we performed a principal components analyses (PCA), in which the Principal Components 1 and 2 (PC1 and PC2, respectively) were extracted through Varimax 
orthogonal rotation. Variables were also plotted in the orthogonal space defined by PC1 and PC2. Unless otherwise stated, the confidence level used was $\mathrm{p}=0.05$.

\subsubsection{Experiment 6: Effect of NT and liming on plant mycorrhization}

\subsubsection{Field measurements and sampling design}

After the first autumn rains in October 2015, the mixture of local varieties of Avena sativa L. (74\%) and Vicia sativa L. (26\%) was sown on November $11^{\text {th }} 2015$ using a direct sowing machine and the fertilizer $\left(36 \mathrm{~kg} \mathrm{~N} \mathrm{ha}^{-1,} 72 \mathrm{~kg} \mathrm{~K} \mathrm{ha}^{-1}\right.$ and $72 \mathrm{~kg} \mathrm{P}$ $\mathrm{ha}^{-1}$ ) was applied. After the plant emergence, the nascence of both species was calculated as the percentage of emerged seedlings from the total amount of sowed seeds, as determined in a delimited area of $1 \mathrm{~m} \times 1 \mathrm{~m}$ in each plot. The precipitation and temperature in the area during the season can be seen in Fig. 3.2.6.

Ten plants of each species along with an intact root system were collected three times during the 2015/2016 growing season on March $13^{\text {th }}$, May $1^{\text {st }}$ and May $31^{\text {st }} 2016$ (123, 172 and 202 days after sowing (DAS), respectively). The sampling was performed according to the different growth stages of oat: 123 DAS corresponded with tillering stage (approximately three leaves per plant), 172 DAS with the early jointing stage and 202 with the milk stage. After the transportation to laboratory, aboveground biomass was cut off at the surface level, washed and dried at $70^{\circ} \mathrm{C}$ until constant weight. The amount of aboveground biomass is expressed in $\mathrm{g}$ of dry biomass per plant. Roots were carefully washed and a sub-sample was conserved in ethanol (50\%) for mycorrhizal colonization determination. Furthermore, total biomass production was determined by harvesting $1 \mathrm{~m}^{2}$. Oat and vetch plants were harvested separately, dried at $70^{\circ} \mathrm{C}$ until constant weight and oat and vetch biomass production was converted to $\mathrm{kg} \mathrm{ha}^{-1}$. 


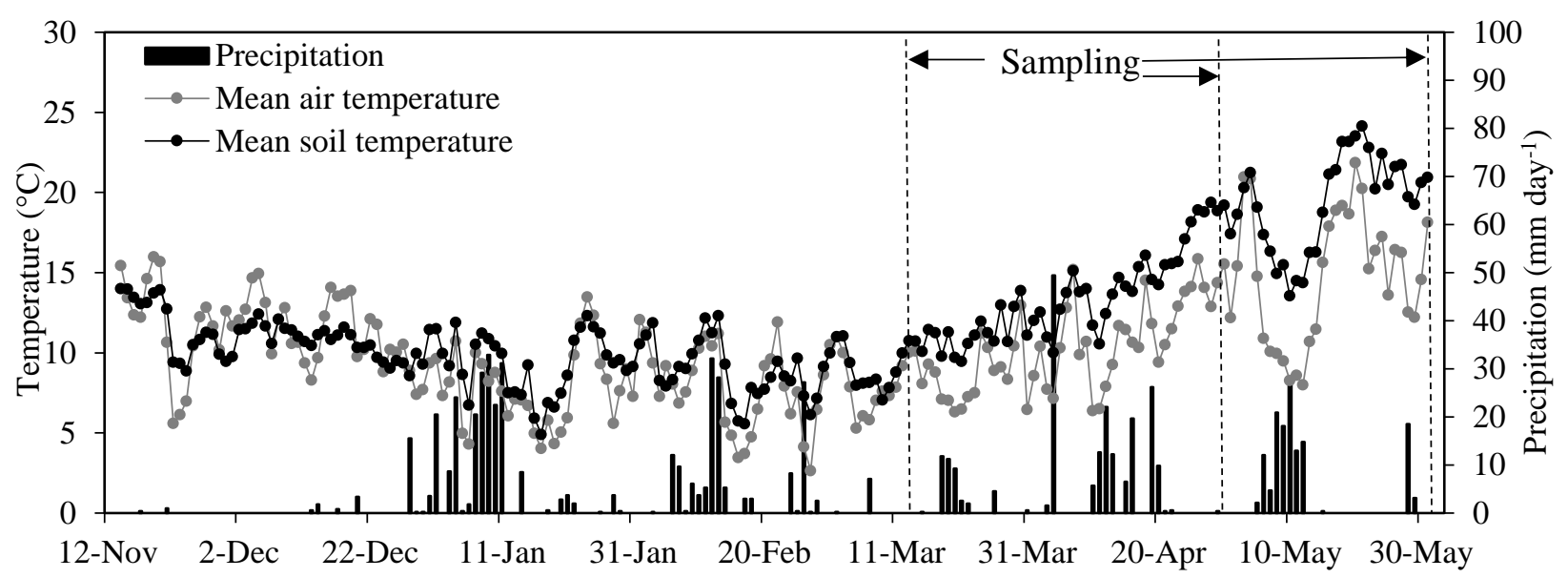

Fig. 3.2.5: Daily mean air and soil temperatures and precipitations during the study period from sowing (November $11^{\text {th }} 2015$ ) to the harvest (May 31 ${ }^{\text {st }} 2016$ ). Data obtained from Guadalupe meteorological station.

Soil samples were collected at all three sampling times from the depth of $10 \mathrm{~cm}$, where the vast majority of the roots were located. Due to high density of plants and tangled roots, a composite soil sample was obtained comprising overlapping rhizosphere of both species. Part of the soil was stored immediately at $4^{\circ} \mathrm{C}$ for quantification of dissolved organic and inorganic $\mathrm{N}$ content and enzymatic activity. Another part was air-dried for analysis of soil available macro- and micronutrients, soil $\mathrm{pH}$ and EC. Temperature registers (DS1922L Thermochron iButton, AlphaOmega Electronics; Madrid, Spain) were placed randomly in three NT and three TT plots in the depth of $5 \mathrm{~cm}$ and soil temperature was measured hourly during the whole study period. Soil moisture content was determined once a month by over drying at $105^{\circ} \mathrm{C}$ until the constant weight.

\subsubsection{Laboratory analysis}

Mycorrhizal parameters and aboveground biomass analysis: Fresh fine roots were washed, cut into $2-\mathrm{cm}$ pieces and cleared with $10 \% \mathrm{KOH}$. After clearing, root segments were stained with 5\% solution of ink-vinegar (Vierheilig et al. 1998) followed by rinsing with tap water. Mycorrhizal root colonization was determined by magnified intersections method (McGonigle et al. 1990) by inspection of 100 views under microscope. Mycorrhizal colonization was calculated as a percentage of colonized root segments from total observed segments.

A sample of $0.4 \mathrm{~g}$ of dried ball-milled aboveground biomass was weighted into microwave vessel (Speedwave four, Berghof, Eningen, Germany) and digested with 
hydrogen peroxide $\left(\mathrm{H}_{2} \mathrm{O}_{2}\right)$ and nitric acid $\left(\mathrm{HNO}_{3}\right)$ by heating to $145^{\circ} \mathrm{C}$ (10 min ramp) for five minutes followed by heating to $190^{\circ} \mathrm{C}$ (five $\mathrm{min}$ ramp) for $10 \mathrm{~min}$. The $\mathrm{P}$ content in the digestion extracts was quantified colorimetrically using molybdenum blue method proposed by Murphy and Riley (1962). Total N content in plant biomass was determined using Kjeldahl apparatus after digestion and steam distillation (Bremner and Mulvaney 1982).

Soil analysis The $\beta$-glucosaminidase activity $(\mathrm{Glm})$ was determined according to method proposed by Parham and Deng (2000) with p-nitrophenyl-N-acetyl- $\beta$-Dglucosaminide as substrate. The DHAse was estimated using 2-(4-Iodophenyl)-3-(4nitrophenyl)-5-phenyltetrazolium chloride (INT) as a substrate using method of Trevors et al. (1982) modified by García et al. (1993).

Available soil nutrients were extracted from air-dried soil with Mehlich III extractant (Mehlich 1984). Available P was quantified colorimetrically (Murphy and Riley 1962) and $\mathrm{Ca}$ and $\mathrm{Mg}$ were determined by atomic absorption spectrophotometry using a Perkin Elmer AAnalist 400.

Soil EN was extracted with potassium sulphate $\left(\mathrm{K}_{2} \mathrm{SO}_{4}, 0.5 \mathrm{M}\right)$ and $\mathrm{NH}_{4}{ }^{+}$and $\mathrm{NO}_{3}{ }^{-}$concentrations were determined colorimetrically using the sodium salicylate method (Forster JC 1995) and sulphanilamide and N-(-naphthyl) ethylendiamine dihydrochloride method (Miranda et al. 2001), respectively. Total extractable N was quantified by Kjeldahl procedure after digestion and steam distillation (Bremner and Mulvaney 1982). Extractable organic N (EON) was calculated by resting inorganic $N$ from EN. Soil pH and electric conductivity were measured in water extracts (1:2.5).

\subsubsection{Statistical analysis}

Data of the parameters determined in the three samplings were analyzed statistically with a LMM using the SPSS 22 software (IBM SPSS, Inc., Chicago, USA). The model was performed with a full factorial design. The different soil tillage $(T)$, the liming amendment (A) and the sampling date (Dt) were used as fixed, and the different plots $(n=16)$ were used as a random effect. When necessary, the means of the sampling dates were separated using LSD post hoc test $(\mathrm{p}<0.05)$. The data collected at harvest were analysez with a general lineal model with different soil tillage (T) and the liming amendment (A) as fixed factor and the field block $(n=4)$ as random factor. All the data 
were tested for normality and homogenity prior soil analysis and the data were logtransformed when necessary. 


\section{RESULTS}

\subsection{Experiment 1: Seasonal variation of microbial and enzymatic activity}

\subsubsection{Precipitations, soil water content and soil temperature}

Monthly precipitations between November 2014 and October 2015 are shown in Fig. 4.1.1. Although the total rainfall for this period $(785 \mathrm{~mm})$ did not differ from the historical mean $(798 \mathrm{~mm})$, the rainfall distribution followed different pattern when compared with the historical data (Fig. 4.1.1), registering higher rainfall in November 2014 but much lower precipitations during the following months (December 2014, January, February, March and May 2015). This coincided with warmer months when we compared the registered temperatures with the historical data in the period between March and July (Fig. 4.1.1). The mean temperature for the whole study period was 0.5 ${ }^{\circ} \mathrm{C}$ higher than historical mean, but more than $1{ }^{\circ} \mathrm{C}$ higher than the mean summer temperature recorded between 1961 and 1990.
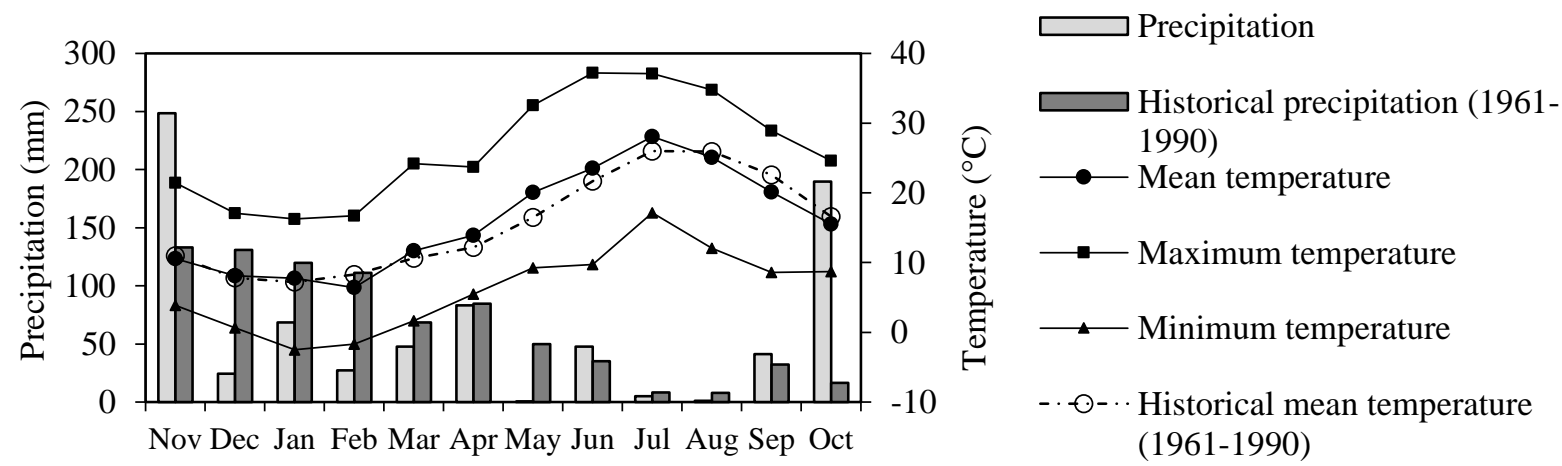

Fig. 4.1.1. Precipitation, minimum temperature, maximum temperature and mean temperature for the study period (2014-2015) and the historical data of precipitation and mean temperature for the period 1961-1990. Data obtained from Guadalupe meteorological station.

Soil GWC varied significantly during the study period (Fig. 4.1.2) with the highest moisture content in November and the minimum values in summer. The NT plots showed higher GWC respect to TT at 0-5 cm from December to April and from July to September $(\mathrm{p}<0.05)$. However, in the 5-10 cm soil layer the GWC was higher in TT than in NT in November and January and lower in April, August and September. It is remarkable that in November, six of the eight TT plots were saturated with water at 5 cm below soil surface. 


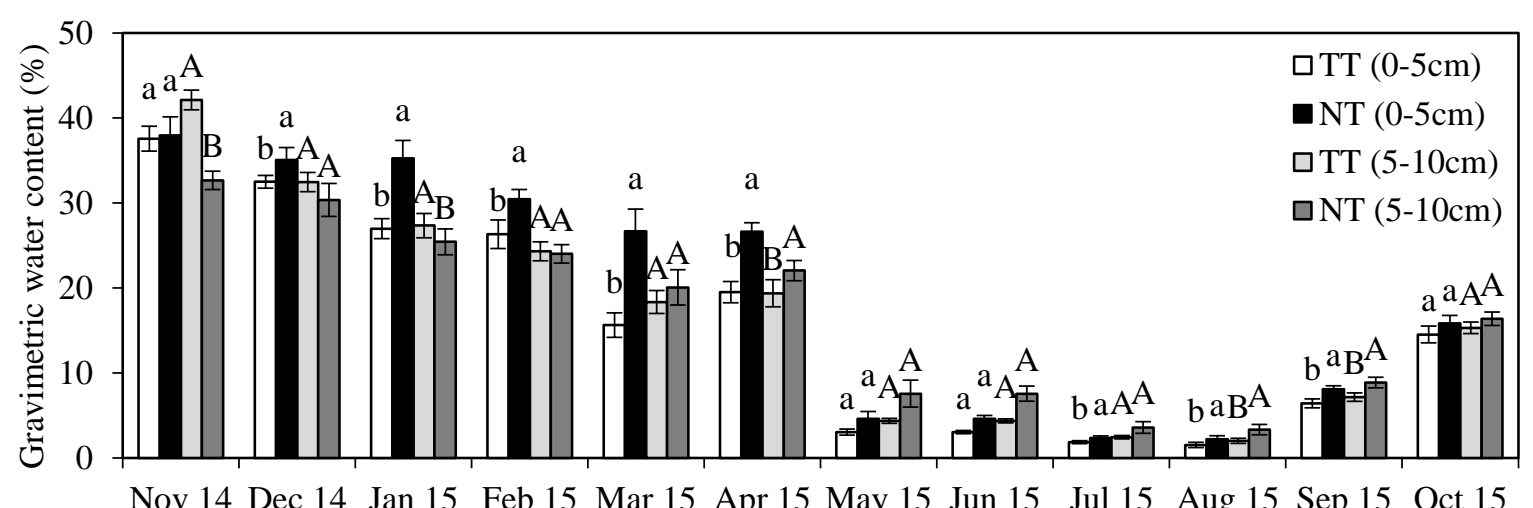

Fig. 4.1.2 Gravimetric soil water content (GWC) of treatments grouped in traditional tillage (TT) or notillage (NT) (n=8) at the depth of 0-5 cm and 5-10 cm during the 2014-2015 study season. The different lowercase and uppercase letters indicate significant differences $(\mathrm{p}<0.05)$ between TT and NT at $0-5 \mathrm{~cm}$ and 5-10 cm, respectively.

Soil temperature registered at $5 \mathrm{~cm}$ depth showed lower mean temperatures $(\mathrm{p}<0.05)$ in July and August for the NT treatments than the TT and we also found lower maximum temperatures in March, April, July and August in NT (Table 4.1.1). In March, the recorded minimum temperature was found to be higher in NT than TT plots $\left(9.2{ }^{\circ} \mathrm{C}\right.$ compared to $\left.7.7^{\circ} \mathrm{C}\right)$.

Table 4.1.1: Maximum, minimum and mean monthly soil temperatures between November 2014 and October 2015 at $5 \mathrm{~cm}$ depth

\begin{tabular}{|c|c|c|c|c|c|c|c|c|c|c|c|c|}
\hline & Nov & Dec & Jan & Feb & Mar & Apr & May & Jun & Jul & Aug & Sep & Oct \\
\hline \multicolumn{13}{|c|}{ Maximum soil temperature $\left({ }^{\circ} \mathrm{C}\right)$} \\
\hline TT & $16.5 \mathrm{a}$ & $15.4 \mathrm{a}$ & $12.2 \mathrm{a}$ & $13.4 \mathrm{a}$ & $18.7 \mathrm{a}$ & $23.5 \mathrm{a}$ & $32.9 \mathrm{a}$ & $38.6 \mathrm{a}$ & $46.5 \mathrm{a}$ & $45.7 \mathrm{a}$ & $34.2 \mathrm{a}$ & $22.1 \mathrm{a}$ \\
\hline NT & $16.1 \mathrm{a}$ & $15.2 \mathrm{a}$ & $11.9 \mathrm{a}$ & $12.6 \mathrm{a}$ & $16.2 b$ & $21.1 \mathrm{~b}$ & $29.8 \mathrm{a}$ & $34.9 \mathrm{a}$ & $42.8 \mathrm{~b}$ & $40.1 b$ & $30.4 \mathrm{a}$ & $21.1 \mathrm{a}$ \\
\hline \multicolumn{13}{|c|}{ Mean soil temperature $\left({ }^{\circ} \mathrm{C}\right)$} \\
\hline TT & $10.1 \mathrm{a}$ & $7.6 \mathrm{a}$ & $8.9 \mathrm{a}$ & $6.2 \mathrm{a}$ & $12.2 \mathrm{a}$ & $16.7 \mathrm{a}$ & $24.2 \mathrm{a}$ & $28.9 \mathrm{a}$ & $34.4 \mathrm{a}$ & $32.5 \mathrm{a}$ & $24.9 \mathrm{a}$ & $17.7 \mathrm{a}$ \\
\hline NT & $10.1 \mathrm{a}$ & $7.4 \mathrm{a}$ & $8.5 \mathrm{a}$ & $6.0 \mathrm{a}$ & $12.1 \mathrm{a}$ & $16.3 \mathrm{a}$ & $23.5 \mathrm{a}$ & $27.7 \mathrm{a}$ & $32.7 b$ & $31.9 b$ & $24.0 \mathrm{a}$ & $17.2 \mathrm{a}$ \\
\hline \multicolumn{13}{|c|}{ Minimum soil temperature $\left({ }^{\circ} \mathrm{C}\right)$} \\
\hline TT & $9.9 \mathrm{a}$ & $5.3 \mathrm{a}$ & $4.9 \mathrm{a}$ & $5.1 \mathrm{a}$ & $7.7 b$ & $11.8 \mathrm{a}$ & $17.5 \mathrm{a}$ & $21.3 \mathrm{a}$ & $25.1 \mathrm{a}$ & $23.0 \mathrm{a}$ & $17.3 \mathrm{a}$ & $15.6 \mathrm{a}$ \\
\hline NT & $9.7 \mathrm{a}$ & $5.1 \mathrm{a}$ & $4.8 \mathrm{a}$ & $5.2 \mathrm{a}$ & $9.2 \mathrm{a}$ & $12.8 \mathrm{a}$ & $18.3 \mathrm{a}$ & $22.0 \mathrm{a}$ & $23.1 \mathrm{a}$ & $24.7 \mathrm{a}$ & $18.0 \mathrm{a}$ & $15.3 \mathrm{a}$ \\
\hline
\end{tabular}

\subsubsection{Soil properties}

Tillage and soil depth affected $(\mathrm{p}<0.001)$ both SOC and POxC, with higher values in the NT plots and in the $0-5 \mathrm{~cm}$ soil layer when compared to TT and 5-10 cm layer, respectively (Table 4.1.2). The interaction between tillage and depth $(\mathrm{p}<0.001)$ reflects the stronger stratification of the SOC in the NT in comparison with the TT plots, as the differences between the SOC of the upper and lower soil layer were greater in NT. 
Sampling date affected the SOC content of all treatments $(p<0.001)$, the highest SOC was recorded in July and the lowest in October (LSD post-hoc, $\mathrm{p}<0.05$ ). However, POxC showed the highest values in July but the lowest were found both in April and October (LSD post-hoc test, $\mathrm{p}<0.05)$. The interaction between the sampling date and the tillage $(\mathrm{p}<0.05)$ reflects that the highest differences in SOC between the NT and the TT plots were recorded in July meanwhile the lowest were measured in January. In the case of POxC $(\mathrm{p}<0.01)$, the highest differences were also found in July and the lowest in October. Finally, although liming did not affect the SOC, the POxC was higher $(\mathrm{p}<0.05)$ in the amended plots.

Table 4.1.2: The content of SOC, POxC and soil $\mathrm{pH}$

\begin{tabular}{|c|c|c|c|c|c|c|c|c|c|c|c|c|c|}
\hline \multirow[t]{2}{*}{$\begin{array}{l}\text { Depth } \\
(\mathrm{cm})\end{array}$} & \multirow[t]{2}{*}{ Treat. } & \multicolumn{4}{|c|}{$\begin{array}{c}\text { SOC } \\
\left(\mathrm{g} \mathrm{kg}^{-1}\right)\end{array}$} & \multicolumn{4}{|c|}{$\mathrm{pH}$} & \multicolumn{4}{|c|}{$\begin{array}{c}\text { POxC } \\
\left(\mathrm{mg} \mathrm{kg}^{-1}\right)\end{array}$} \\
\hline & & Jan & Apr & Jul & Oct & Jan & Apr & Jul & Oct & Jan & Apr & Jul & Oct \\
\hline \multirow[t]{4}{*}{$0-5$} & TT & 34.0 & 31.7 & 35.8 & 30.9 & 4.94 & 4.67 & 4.42 & 4.00 & 1.21 & 0.77 & 0.79 & 0.92 \\
\hline & TT-A & 33.2 & 31.6 & 33.4 & 32.6 & 6.70 & 6.72 & 6.36 & 5.95 & 1.21 & 0.94 & 1.02 & 1.10 \\
\hline & NT & 45.1 & 40.9 & 50.0 & 42.0 & 4.91 & 4.94 & 4.51 & 4.48 & 1.65 & 1.24 & 1.45 & 1.28 \\
\hline & NT-A & 41.5 & 48.0 & 48.7 & 42.3 & 6.69 & 6.40 & 6.08 & 5.98 & 1.66 & 1.30 & 1.49 & 1.29 \\
\hline \multirow[t]{4}{*}{$5-10$} & $\mathrm{TT}$ & 33.7 & 31.2 & 33.9 & 27.2 & 4.74 & 4.62 & 4.37 & 4.30 & 0.98 & 0.89 & 0.78 & 0.80 \\
\hline & TT-A & 31.2 & 31.1 & 33.4 & 27.3 & 6.37 & 5.83 & 6.31 & 5.19 & 1.05 & 0.92 & 1.03 & 0.93 \\
\hline & NT & 32.4 & 32.4 & 39.9 & 30.0 & 4.49 & 4.61 & 4.42 & 4.23 & 0.88 & 0.90 & 1.01 & 0.86 \\
\hline & NT-A & 30.7 & 31.0 & 37.2 & 26.4 & 5.62 & 5.59 & 5.49 & 4.85 & 0.95 & 0.88 & 1.06 & 0.88 \\
\hline
\end{tabular}

TT, traditional tillage; TT-A, traditional tillage and liming amendment application; NT, no-tillage; NT-A, no-tillage and liming amendment application

The soil $\mathrm{pH}$ was significantly affected $(\mathrm{p}<0.001)$ by the depth, by liming and by their interaction, showing the highest values in the $0-5 \mathrm{~cm}$ layer of the amended plots (Table 4.1.2). Soil $\mathrm{pH}$ decreased significantly $(\mathrm{p}<0.001)$ from the highest value in January to the lowest in October (LSD post-hoc test, $p<0.05)$. An interaction $(\mathrm{p}<0.01)$ was found between the depth and the tillage showing that the $\mathrm{pH}$ at $5-10 \mathrm{~cm}$ layer was higher in the TT than in the NT plots.

\subsubsection{Microbial biomass and soil basal respiration}

The MBC and the MBN were significantly affected by depth $(\mathrm{p}<0.001)$, tillage $(\mathrm{p}<0.001)$, sampling date $(\mathrm{p}<0.001)$ and liming ( $\mathrm{MBC} \mathrm{p}<0.001$ and $\mathrm{MBN} \mathrm{p}<0.01)$ (Fig. 4.1.3). In both, the values of the $0-5 \mathrm{~cm}$ layer and the NT treatments were higher than in 
the 5-10 cm layer and TT, respectively. However, the effect of the liming followed the opposite trend in both parameters and the MBC was higher in non-amended plots $(\mathrm{p}<0.001)$ while MBN increased with liming application $(\mathrm{p}<0.01)$. The seasonal variation of $\mathrm{MBC}$ and the $\mathrm{MBN}$ followed the same patterns during the year, showing the highest values in July and October and the lowest in January (LSD post-hoc $\mathrm{p}<0.05)$. The same trend was observed in both MBC and MBN; the differences between TT and NT were higher in the $0-5 \mathrm{~cm}$ layer $(\mathrm{p}<0.001)$ and the highest differences between $0-5 \mathrm{~cm}$ and $5-10 \mathrm{~cm}$ and between TT and NT were both found in July. The interactive effect of sampling depth and liming on MBC $(\mathrm{p}<0.001)$ revealed higher differences between amended and the non-amended treatments in the uppermost soil layer.

$0-5 \mathrm{~cm}$
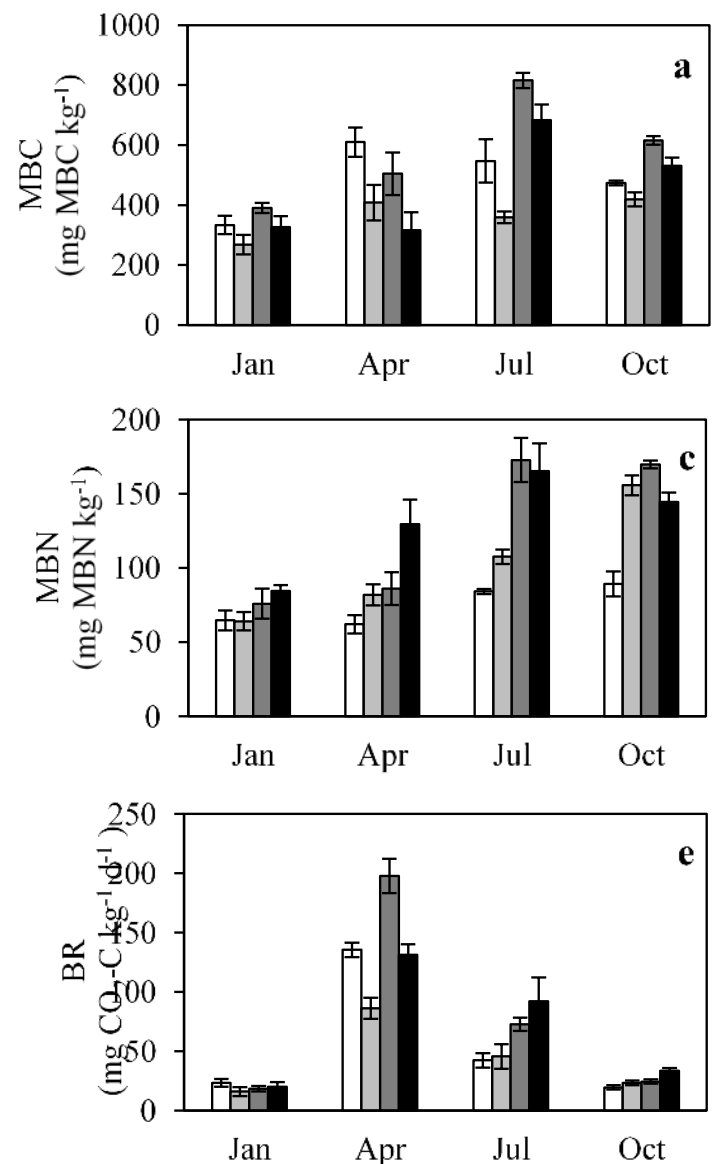

$5-10 \mathrm{~cm}$
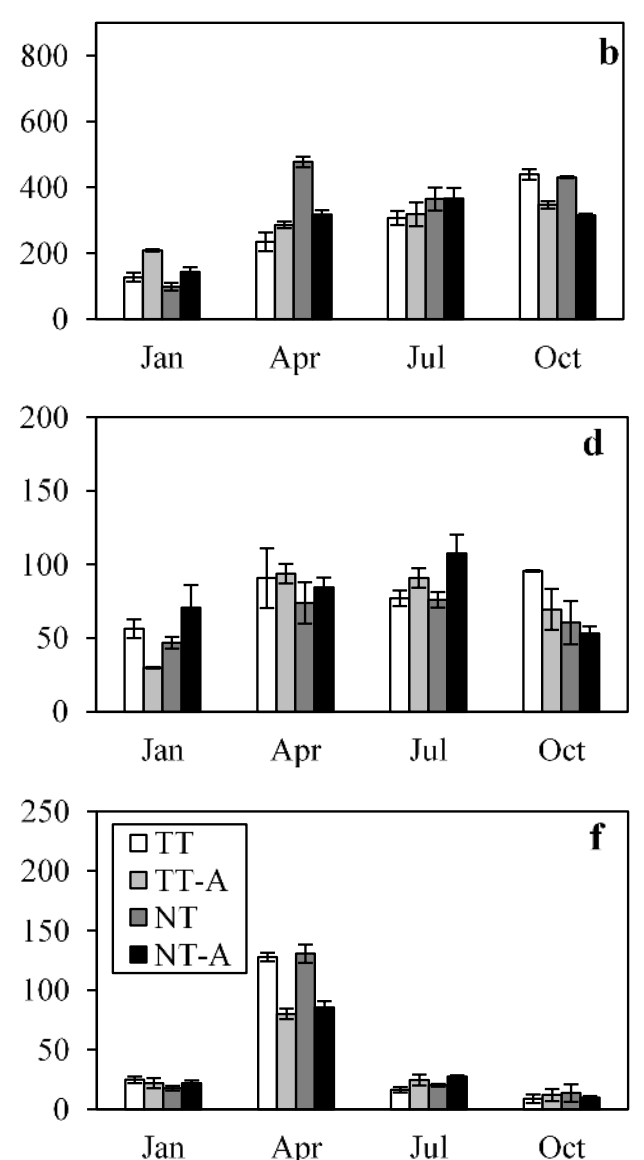

Fig. 4.1.3. Microbial biomass $C(a, b)$, microbial biomass $N(c, d)$ and basal respiration (e, $f$ ), in $0-5 \mathrm{~cm}$ soil layer (a, c, e) and 5-10 cm soil layer (b, d, f). TT, traditional tillage; TT-A, traditional tillage and Liming application; NT, no-tillage; NT-A, no-tillage and Liming application. MBC, microbial biomass carbon; MBN, microbial biomass nitrogen; $B R$, basal respiration. Bars represent standard errors $(n=4)$. 
The soil BR depended strongly on the season $(\mathrm{p}<0.001)$ and the highest peak was recorded in April (LSD post-hoc $\mathrm{p}<0.05$ ) meanwhile the lowest rates were measured in January and October (Fig. 4.1.3). The BR was also affected significantly by the depth $(\mathrm{p}<0.001 ; 0-5 \mathrm{~cm}>5-10 \mathrm{~cm})$, tillage $(\mathrm{p}<0.001, \mathrm{NT}>\mathrm{TT})$ and by liming $(\mathrm{p}<0.05$, nonamended>amended). These effects were reflected in the higher respiration rates measured in the 0-5 cm layer, in the NT treatments and in the non-amended treatments. Remarkable is the interaction between the soil depth and the tillage $(\mathrm{p}<0.001)$ which showed that the highest differences between both tillage practices were found in the $0-5$ $\mathrm{cm}$ layer. Similarly, the interaction between sampling depth and liming $(\mathrm{p}<0.05)$ showed the main differences in the soil top layer. Finally, the interaction between the sampling date and the tillage $(\mathrm{p}<0.001)$ indicated the variation of the differences in time with the highest differences in April and July.

\subsubsection{Soil enzymes}

All six soil EAs were significantly affected by the soil depth $(\mathrm{p}<0.001)$ showing the higher values in the $0-5 \mathrm{~cm}$ layer (Fig.4.1.4). The tillage practice had also a significant influence in the six soil enzymatic activities although the effect was more remarkable in the DHase, Gls and Urease $(\mathrm{p}<0.001)$ than in Glm, ASase and PHase $(p<0.01)$. All of the enzymes showed higher activities under the NT than in TT, with the exception of DHase which exhibited a higher activity in the TT plots (Fig. 4.1.4). Also the activity of the six enzymes showed a significant interaction between the soil depth and the tillage management. In one hand, Gls, Glm, ASase, PHase and Urease showed a higher stratification $(\mathrm{p}<0.001)$ in their activities in NT because the difference between the $0-5 \mathrm{~cm}$ and the $5-10 \mathrm{~cm}$ layer was higher than in the TT. In the other hand, this interaction in DHase activity $(\mathrm{p}<0.05)$ reflects that the differences between TT and NT were higher in the 5-10 cm layer when compared to the uppermost soil layer.

The application of a liming increased the activity of DHase $(\mathrm{p}<0.001)$, Gls $(p<0.01)$ and PHase $(p<0.05)$ respect to non-amended plots (Fig. 4.1.4). Both urease and ASase activities exhibited an interaction between the liming and the soil depth $(\mathrm{p}<0.05$ and $\mathrm{p}<0.01$, respectively) which in the case of urease resulted in much higher activity in the $0-5 \mathrm{~cm}$ layer in limed treatments, but in case of the ASase in much higher activity in non-amended plots for the $0-5 \mathrm{~cm}$. Only the DHase activity showed the combined effect of tillage and liming $(\mathrm{p}<0.001)$ where similar values were recorded for both NT 
and TT treatments when liming was not applied, but $34.7 \%$ higher activity in TT-A compared to NT-A plots.
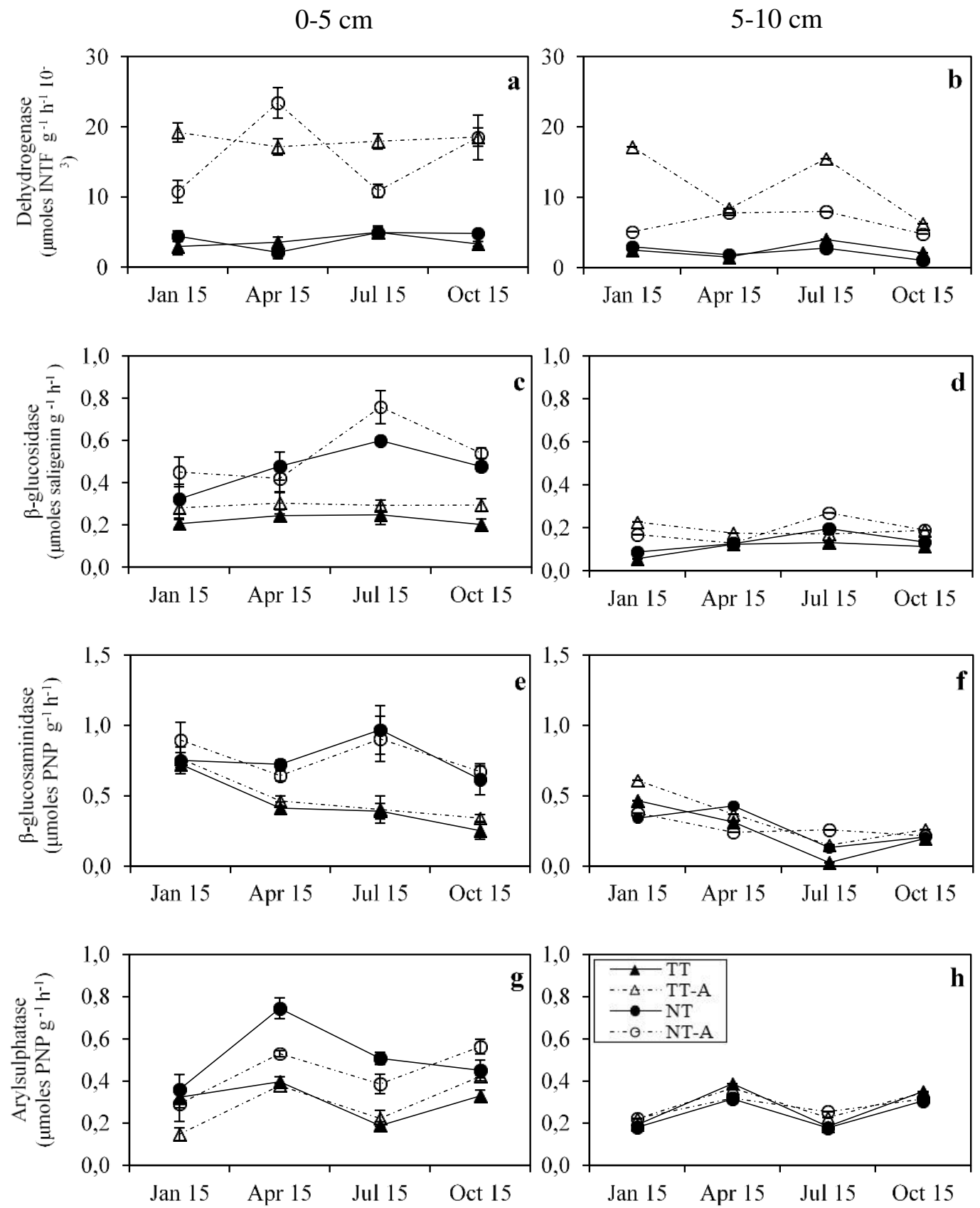

Fig. 4.1.4: The activity of six enzymes catalyzing key nutrient transformation processes in $0-5 \mathrm{~cm}$ soil layer (a, c, e, g, I, k) and 5-10 cm soil layer (b, d, f, h, j, l) TT, traditional tillage; TT-A, traditional tillage and liming application; NT, no-tillage; NT-A, no-tillage and Liming application. Bars represent standard errors $(n=4)$.

The seasonality introduced significant changes $(p<0.001)$ in the activity of all the EAs with the exception of DHase which was not affected. However, its effect varied depending on enzyme and did not reveal a similar pattern for all of them. The highest 
value of Gls was measured in July meanwhile the lowest were detected in January and April (LSD post-hoc $\mathrm{p}<0.05$ ). The activity of Glm was the highest in January and the lowest in July and October (LSD post-hoc $\mathrm{p}<0.05$ ). In case of ASase, the activity peaked in April and dropped significantly in January and July (LSD post-hoc p<0.05). The activity of PHase was highest in October and lowest in July and the Urease activity was the highest in July and the lowest in January (LSD post-hoc $\mathrm{p}<0.05$ ). In addition, the interaction between the sampling date and the tillage was significant for the DHase, Gls, Glm and Urease activities $(\mathrm{p}<0.001)$ and for ASase activity $(\mathrm{p}<0.05)$. A clear pattern was seen in the Gls, Glm, ASase and Urease activities and in all of them the highest differences between the NT and the TT were found in July. Moreover, the interaction of sampling date and the liming were significant for ASase and PHase $(\mathrm{p}<0.01)$ and for Gls $(\mathrm{p}<0.05)$. In the case of the two first enzymatic activities, there is a trend which shows a change from similar or higher values in the non-amended plots in the January and April to a rising value in limed plots during the last two samplings (summer and autumn) with the highest liming-induced differences in October. However, the Gls activity showed the highest differences in favor to limed soils in January and the lowest difference in April. The last of the two-way interactions between depth and sampling date was significant in case of DHase, Glm and Urease activities, $(\mathrm{p}<0.001)$, for PHase activity $(\mathrm{p}<0.01)$ and for Gls $(\mathrm{p}<0.05)$. In the case of Gls, Glm and Urease the same trend was found with the highest differences between the $0-5 \mathrm{~cm}$ and 5-10 cm layers found in July. However, the activity of PHase followed the opposite trend and in July the lowest differences between both soil depths was observed.

\subsubsection{Correlation among variables}

PCA was used to analyze the relations among the different variables studied. The analysis was performed for each different sampling separately. For the four PCA, most of the variance in the variables could be attributed to two factors with loadings which can explain more of the $50 \%$ of the variance (Fig. 4.1.5, Table 4.1.3). Generally, along the PC1 axis the five hydrolases activities were well correlated with the BR, SOC, $\mathrm{POxC}, \mathrm{MBC}$ and the GWC3m, showing the important legacy effect of soil moisture during the previous moths in the EAs. Moreover, the DH-ase activity was generally well correlated with the $\mathrm{pH}$ along the PC2 axis. In the four sampling dates, the SOC and $\mathrm{pH}$ were loaded in different axis showing their mutual independence. In addition, PCA was performed for the four dates and the sampling points were plotted in the orthogonal 
space defined by PC1 and PC2 (Fig. 4.1.6). PC1 correlated with Urease, MBC, Gls, MBN and SOC; PC2 correlated with GWC, Glm, pH and POxC (Table 4.13, Table 4.1.3). The sampling points shifted downward and towards right following the ordination of January, April, October and July.

Table 4.1.3: Scores of PC1 and PC2 in the PCA of all sampling dates

\begin{tabular}{ccc}
\hline \multicolumn{3}{c}{ Rotated component Matrix } \\
\hline Soil & PC1 & PC2 \\
Parameter & $37.276 \%$ & $24.175 \%$ \\
\hline Urease & $0.936^{\mathrm{a}}$ & \\
MBC & 0.852 & \\
Gls & 0.828 & \\
MBN & 0.767 & \\
SOC & 0.681 & \\
ASase & 0.629 & \\
BR & 0.621 & \\
GWC & & 0.722 \\
Glm & & 0.680 \\
pH & & 0.678 \\
POxC & & 0.674 \\
PHase & & 0.625 \\
GWC3m & 0.545 & 0.552 \\
DHase & & 0.547 \\
\hline
\end{tabular}

${ }^{\mathrm{a}}$ The scores lower than 0.5 not shown

ASase, arylsuplhatase; BR, basal respiration; DHase, dehydrogenase; Glm, glucosaminidase; Gls, glucosidase; GWC, gravimetric water content; GWC3m, mean gravimetric water content for the three months period prior sampling; MBC, microbial biomass carbon; MBN, microbial biomass nitrogen; PHase; phosphatase; POxC; permanganate oxidizable carbon; SOC, soil organic carbon 

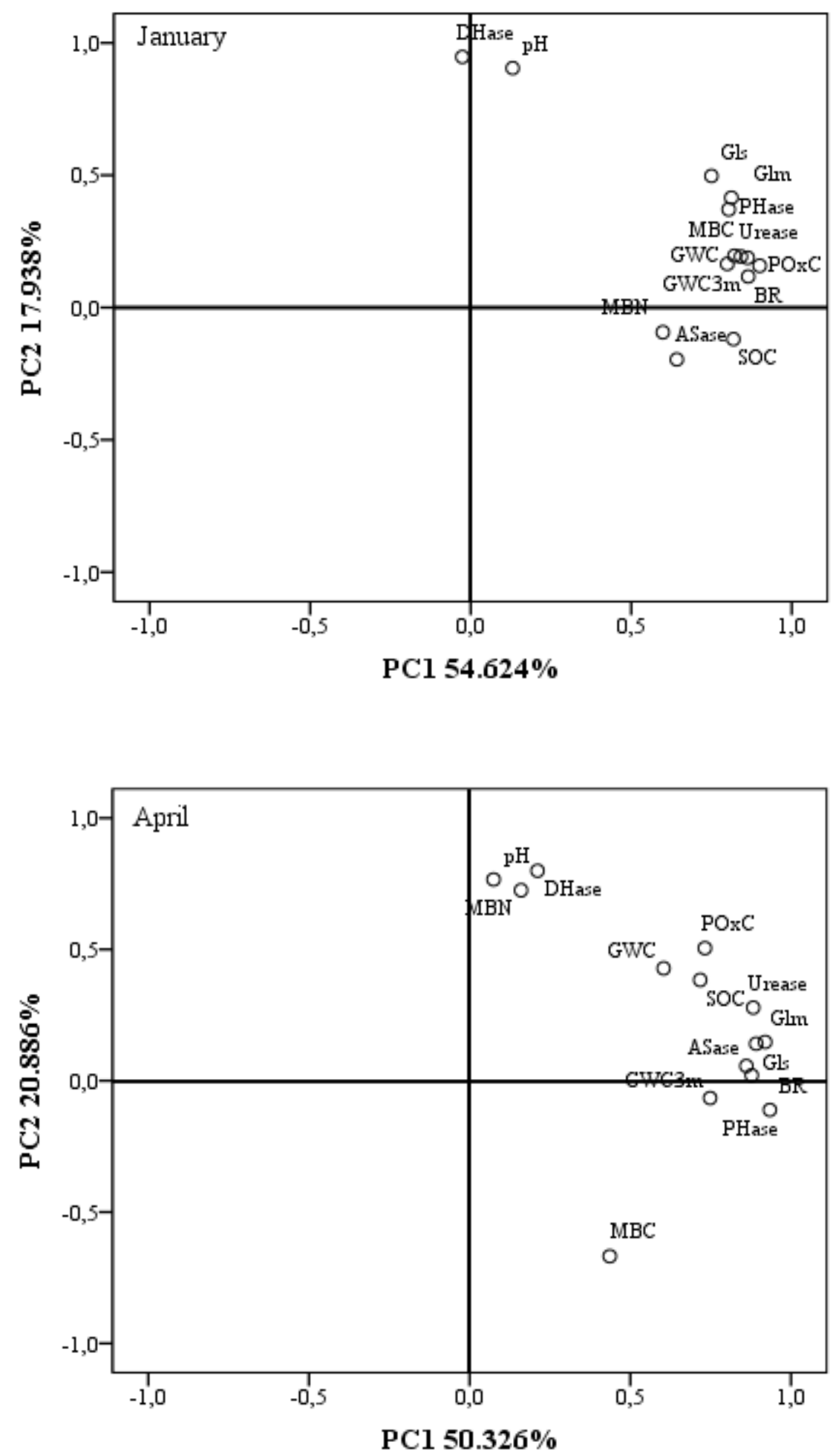

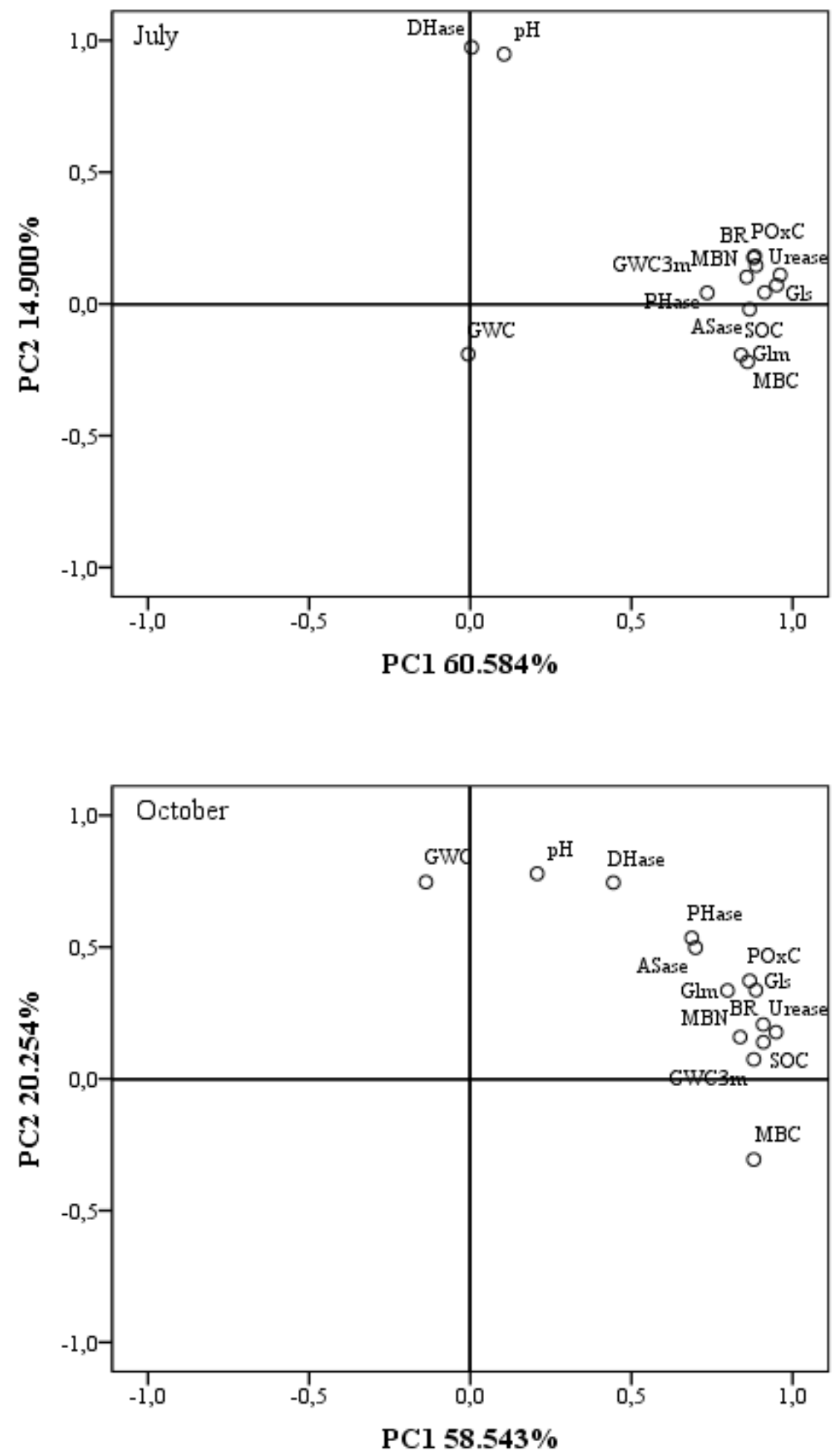

Fig. 4.1.5: Loading plots for soil properties and microbial parameters on Principal Components. ASase, arylsuplhatase; BR, basal respiration; DHase, dehydrogenase; Glm, glucosaminidase; Gls, glucosidase; GWC, gravimetric water content; GWC3m, mean gravimetric water content for the three months period prior sampling; MBC, microbial biomass carbon; MBN, microbial biomass nitrogen; PHase; phosphatase; POxC; permanganate oxidizable carbon; SOC, soil organic carbon 


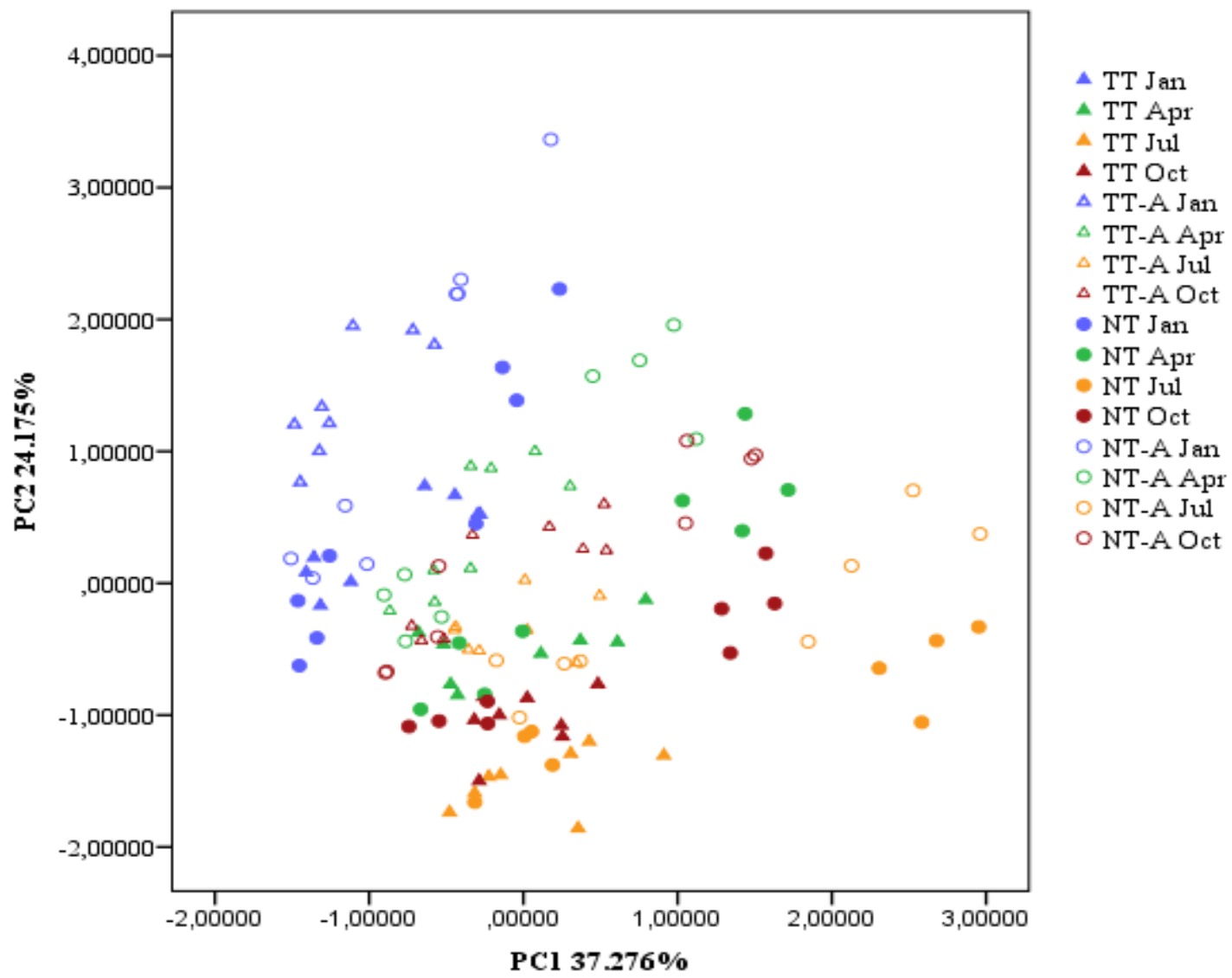

Fig. 4.1.6: PCA loading plots of the sampled soils based on arylsulphatase, glucosidase, glucosaminidase, dehydrogenase, phosphatase and urease activity, basal respiration, soil organic carbon and permanganate oxidizable carbon content, $\mathrm{pH}$ value, carbon and nitrogen of microbial biomass, gravimetric water content and mean gravimetric water content for the three months prior to soil sampling. 


\subsection{Experiment 2: Gross $N$ transformation rates during summer fallow}

\subsubsection{Soil properties}

During the study period (between the first sampling in May and the second sampling in July), the total rainfall of $30 \mathrm{~mm}$ was spread over seven rainfall events (Fig. 4.2.1) and the mean air temperature was $24.4^{\circ} \mathrm{C}$. The mean maximum temperature was $33.4^{\circ} \mathrm{C}$ during the two weeks before the second sampling point. The registered soil temperature at $5 \mathrm{~cm}$ depth during the whole study was $31.5^{\circ} \mathrm{C}$ and the mean soil temperature during the last two weeks prior sampling were $21.7^{\circ} \mathrm{C}$ and $36.6^{\circ} \mathrm{C}$ in May and July, respectively (Fig.4.2.1).

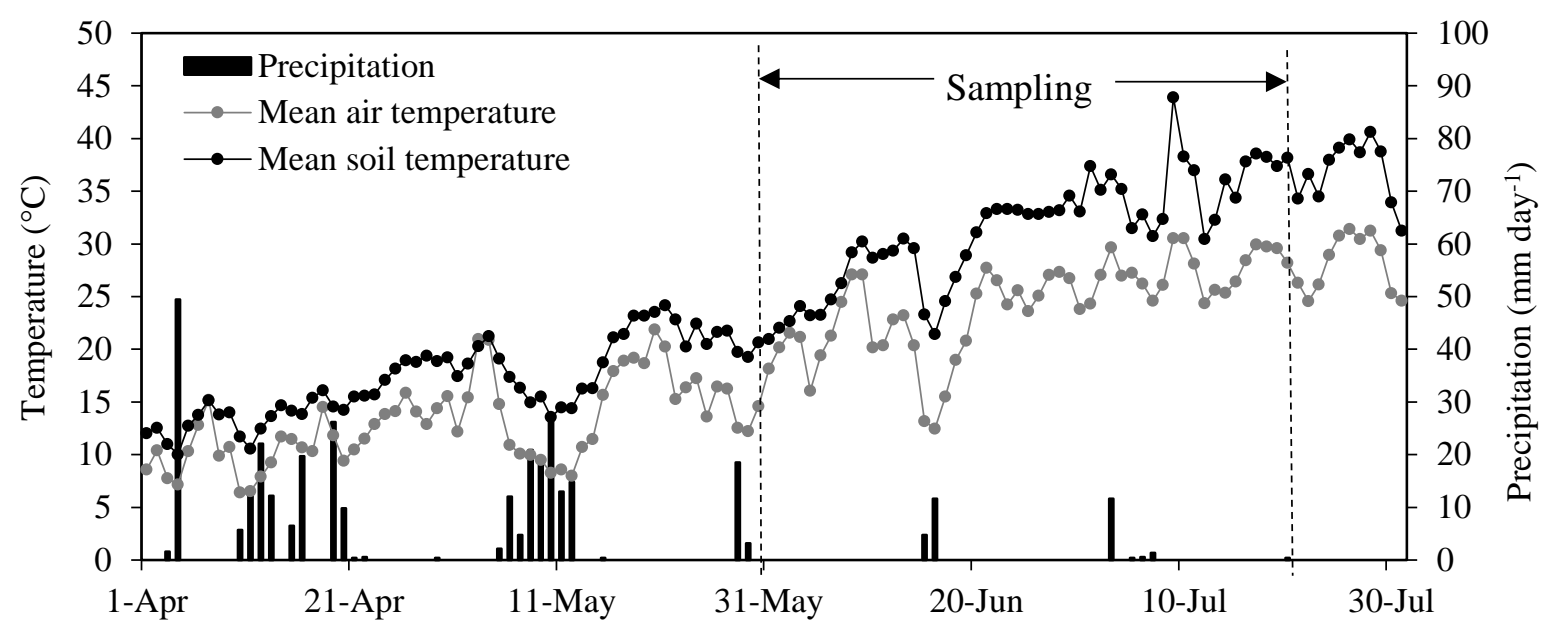

Fig. 4.2.1: Daily air and soil temperatures and precipitations. Data obtained from Guadalupe meteorological station.

The measured GWC and WFPS decreased by $84 \%$ between May and July. While there was no difference between treatments in GWC, there was a positive effect of tillage on WFPS in May (Table 4.2.1). Soil pH was significantly higher in the amended plots both in May and in July (Table 4.2.1) and NT increased both SOC and $\mathrm{TN}$ (Table 4.2.1). The increase in TN in NT plots was higher in July when compared to May. Both DOC and DON followed a similar pattern with higher contents in July and in NT plots while they both decreased with liming (Fig. 4.2.2; Table 4.2.2). The differences in DOC and DON between the tillage practices were higher in July. The interaction between tillage and liming revealed that the decrease in DON due to the amendment application was higher in the TT plots. A significant 9-fold increase was found in $\mathrm{NH}_{4}{ }^{+}-\mathrm{N}$ between May and July (Fig. 4.2.2; Table 4.2.2). However, the $\mathrm{NO}_{3}{ }^{-}-\mathrm{N}$ 
content decreased between May and July, being higher in the non-amended soils under TT but lower in non-amended treatments under NT (Fig. 4.2.2; Table 4.2.2).

Table 4.2.1: Soil $\mathrm{pH}$, soil organic carbon (SOC), total soil nitrogen $(\mathrm{TN})$, gravimetric water content (GWC), water-filled pore space (WFPS) and dehydrogenase activity (Dhase)

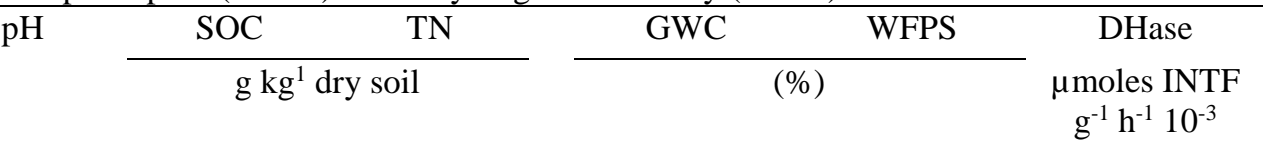

\begin{tabular}{lcccccc}
\hline May & & & & & & \\
TT-A & $5.85(0.06)$ & $28.2(1.0)$ & $1.55(0.06)$ & $11.25(0.42)$ & $44.2(3.91)$ & $8.11(0.72)$ \\
NT-A & $6.04(0.13)$ & $30.3(0.5)$ & $1.79(0.13)$ & $10.47(0.33)$ & $34.4(2.92)$ & $9.66(2.13)$ \\
TT & $4.72(0.02)$ & $27.6(1.2)$ & $1.58(0.06)$ & $11.01(0.44)$ & $44.2(2.26)$ & $2.11(0.22)$ \\
NT & $4.77(0.09)$ & $31.1(1.7)$ & $1.71(0.08)$ & $10.51(0.80)$ & $31.0(2.73)$ & $3.08(0.65)$ \\
\hline July & & & & & & \\
TT-A & $6.19(0.07)$ & $27.8(2.0)$ & $1.51(0.08)$ & $1.80(0.18)$ & $7.09(0.93)$ & $7.05(0.88)$ \\
NT-A & $6.27(0.10)$ & $35.1(2.0)$ & $2.03(0.21)$ & $1.90(0.27)$ & $6.17(0.85)$ & $8.90(1.16)$ \\
TT & $5.28(0.07)$ & $25.8(0.9)$ & $1.64(0.03)$ & $1.61(0.12)$ & $6.62(0.56)$ & $4.11(0.52)$ \\
NT & $5.15(0.08)$ & $30.1(1.8)$ & $1.84(0.10)$ & $1.61(0.19)$ & $4.75(0.58)$ & $4.43(0.41)$ \\
\hline Effects & & & & & & \\
D & $* * *$ & n.s. & $*$ & $* * *$ & $* * *$ & n.s. \\
T & n.s. & ** & $*$ & n.s. & $* *$ & n.s. \\
A & $* * *$ & n.s. & n.s. & n.s. & n.s. & $* * *$ \\
DxT & n.s. & n.s. & $*$ & n.s. & $* *$ & n.s. \\
DxA & n.s. & n.s. & n.s. & n.s. & n.s. & n.s. \\
TxA & n.s. & n.s. & n.s. & n.s. & n.s. & n.s. \\
DxTxA & n.s. & n.s. & n.s. & n.s. & n.s. & n.s. \\
\hline
\end{tabular}

Mean (SE). n=4.TT-A traditional tillage with amendment; NT-A no-tillage with amendment; TT traditional tillage without amendment; NT no-tillage without amendment; D sampling date; T tillage; A amendment. $* \mathrm{p}<0.05 ; * * \mathrm{p}<0.01 ; * * * \mathrm{p}<0.001 ;$ n.s. not significant

\subsubsection{Gross $\mathbf{N}$ transformation rates}

Gross $\mathrm{N}$ transformation rates decreased between May and July, with an overall reduction by $40 \%$ and $56 \%$ in gross ammonification and nitrification, respectively (Fig. 4.2.2). The mean values of gross ammonification rates were $1.32 \mathrm{mg} \mathrm{N} \mathrm{kg}^{-1} \mathrm{day}^{-1}$ in TT, $1.43 \mathrm{mg} \mathrm{N} \mathrm{kg}^{-1}$ day $^{-1}$ in TT-A, $1.09 \mathrm{mg} \mathrm{N} \mathrm{kg}^{-1}$ day $^{-1}$ in NT and $2.12 \mathrm{mg} \mathrm{N} \mathrm{kg}^{-1}$ day $^{-1}$ in NT-A. The interaction between tillage and liming revealed that the significant increase caused by amendment was higher in the NT than in the TT plots (Table 4.2.2). Gross nitrification rates were $0.55 \mathrm{mg} \mathrm{N} \mathrm{kg}^{-1}$ day $^{-1}$ in TT, $0.69 \mathrm{mg} \mathrm{N} \mathrm{kg}^{-1}$ day $^{-1}$ in TT-A, 0.32 $\mathrm{mg} \mathrm{N} \mathrm{kg}{ }^{-1}$ day $^{-1}$ in NT and $0.82 \mathrm{mg} \mathrm{N} \mathrm{kg}^{-1}$ day $^{-1}$ in NT-A, and were significantly enhanced in limed plots (Fig. 4.2.2; Table 4.2.2). The $\mathrm{NH}_{4}{ }^{+}$and $\mathrm{NO}_{3}{ }^{-}$immobilization decreased by $74 \%$ and $54 \%$, respectively, between the first and the second sampling although only the $\mathrm{NH}_{4}{ }^{+}$immobilization reduction was statically significant (Fig. 4.2.2; Table 4.2.2). Tillage increased the $\mathrm{NO}_{3}{ }^{-}$immobilization in May and $\mathrm{NH}_{4}{ }^{+}$ immobilization in July (Fig. 4.2.2; Table 4.2.2). 
Table 4.2.2: Effects of sampling date, tillage and amendment application on ammonium and nitrate content, gross ammonification (gross ammon), gross nitrification (gross nitr), ammonium $\left(\mathrm{NH}_{4}{ }^{+} \mathrm{immob}\right)$ and nitrate $\left(\mathrm{NO}_{3}{ }^{-} \mathrm{immob}\right)$ immobilization rates, dissolved organic carbon (DOC), dissolved organic nitrogen (DON), microbial biomass carbon (MBC) and microbial biomass nitrogen (MBN)

\begin{tabular}{lcccccccccc}
\hline & $\mathrm{NH}_{4}^{+}$ & $\mathrm{NO}_{3}^{-}$ & $\begin{array}{l}\mathrm{Gross} \\
\text { ammon }\end{array}$ & $\begin{array}{l}\mathrm{Gross} \\
\text { nitr }\end{array}$ & $\begin{array}{l}\mathrm{NH}_{4}^{+} \\
\mathrm{immob}\end{array}$ & $\begin{array}{l}\mathrm{NO}_{3}^{-} \\
\mathrm{immob}\end{array}$ & $\mathrm{DOC}$ & $\mathrm{DON}$ & $\mathrm{MBC}$ & $\mathrm{MBN}$ \\
$\mathrm{D}$ & $* * *$ & $* * *$ & $* *$ & $* * *$ & $* * *$ & $\mathrm{n} . \mathrm{s}$. & $* * *$ & $* * *$ & $* * *$ & $* * *$ \\
$\mathrm{~T}$ & n.s. & n.s. & n.s. & n.s. & n.s. & n.s. & $*$ & $* *$ & $* *$ & $*$ \\
$\mathrm{~A}$ & n.s. & n.s. & $*$ & $*$ & n.s. & n.s. & $*$ & $* *$ & n.s. & n.s. \\
DxT & n.s. & $*$ & n.s. & n.s. & $*$ & $*$ & $* *$ & $* *$ & n.s. & n.s. \\
DxA & n.s. & n.s. & n.s. & n.s. & n.s. & n.s. & n.s. & $* * *$ & n.s. & n.s. \\
TxA & n.s. & $*$ & $*$ & n.s. & n.s. & n.s. & n.s. & $*$ & n.s. & n.s. \\
DxTxA & n.s. & $*$ & n.s. & n.s. & n.s. & n.s. & n.s. & $* *$ & n.s. & n.s. \\
\hline
\end{tabular}

$D$ sampling date; $T$ tillage; $A$ amendment

$* \mathrm{p}<0.05 ; * * \mathrm{p}<0.01 ; * * * \mathrm{p}<0.001 ;$ n.s. not significant

\subsubsection{Microbial biomass and gene analysis}

The MBC and MBN followed a similar pattern between May and July, decreasing from $306 \mathrm{mg} \mathrm{C} \mathrm{kg}^{-1}$ to $139 \mathrm{mg} \mathrm{C} \mathrm{kg}^{-1}$ and from $43.9 \mathrm{mg} \mathrm{C} \mathrm{kg}^{-1}$ to $17.7 \mathrm{mg} \mathrm{C} \mathrm{kg}^{-1}$ respectively (Fig. 4.2.2). The MBC and MBN were significantly higher in NT plots, while liming decreased the $\mathrm{MBC}$, although this effect was not statistically significant ( $\mathrm{p}=0.056$ ) (Fig. 4.2.2; Table 4.2.2). The DHase activity was strongly affected by liming in both sampling dates being three-times higher in amended plots in May and two-times higher in amended plots in July. 

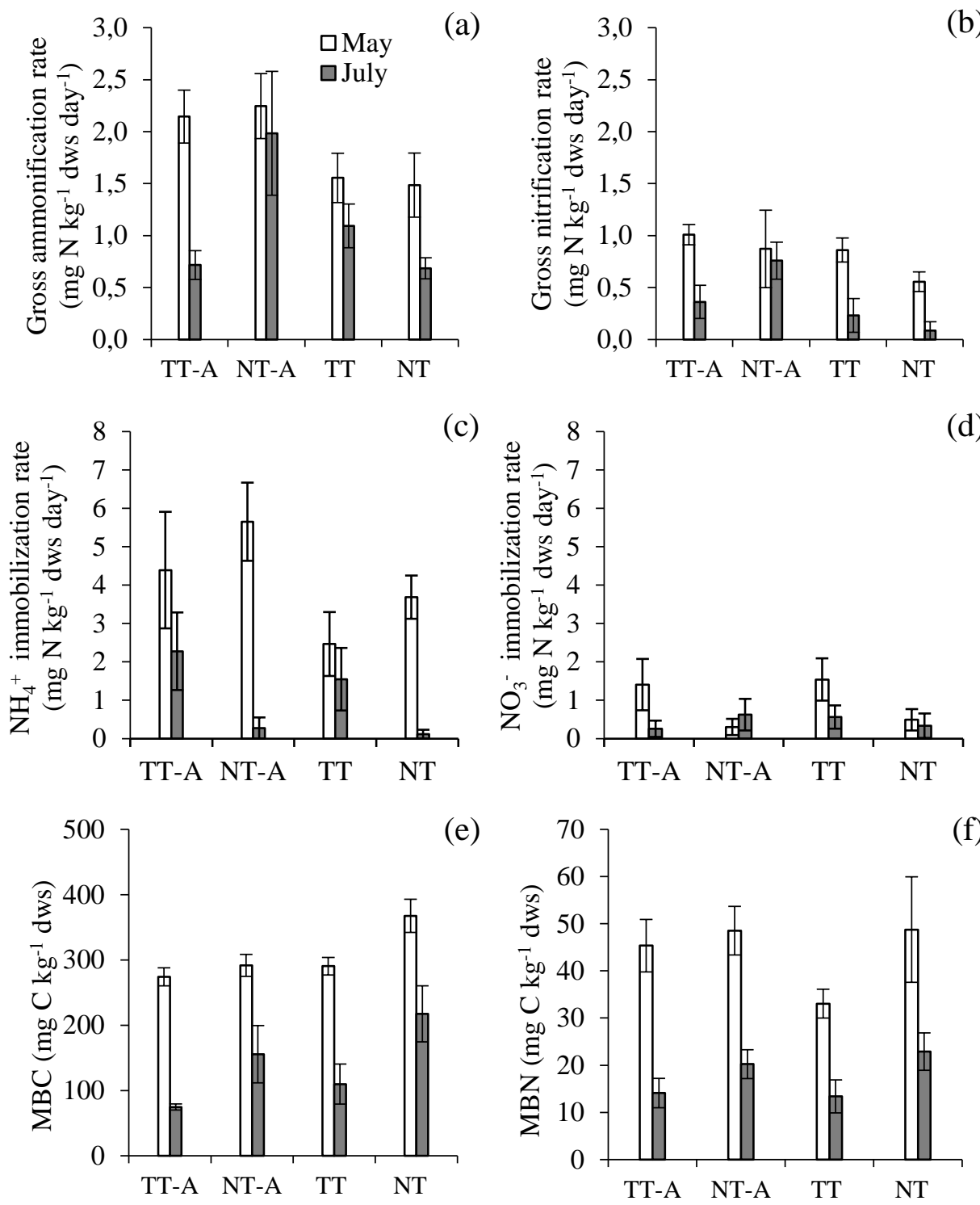

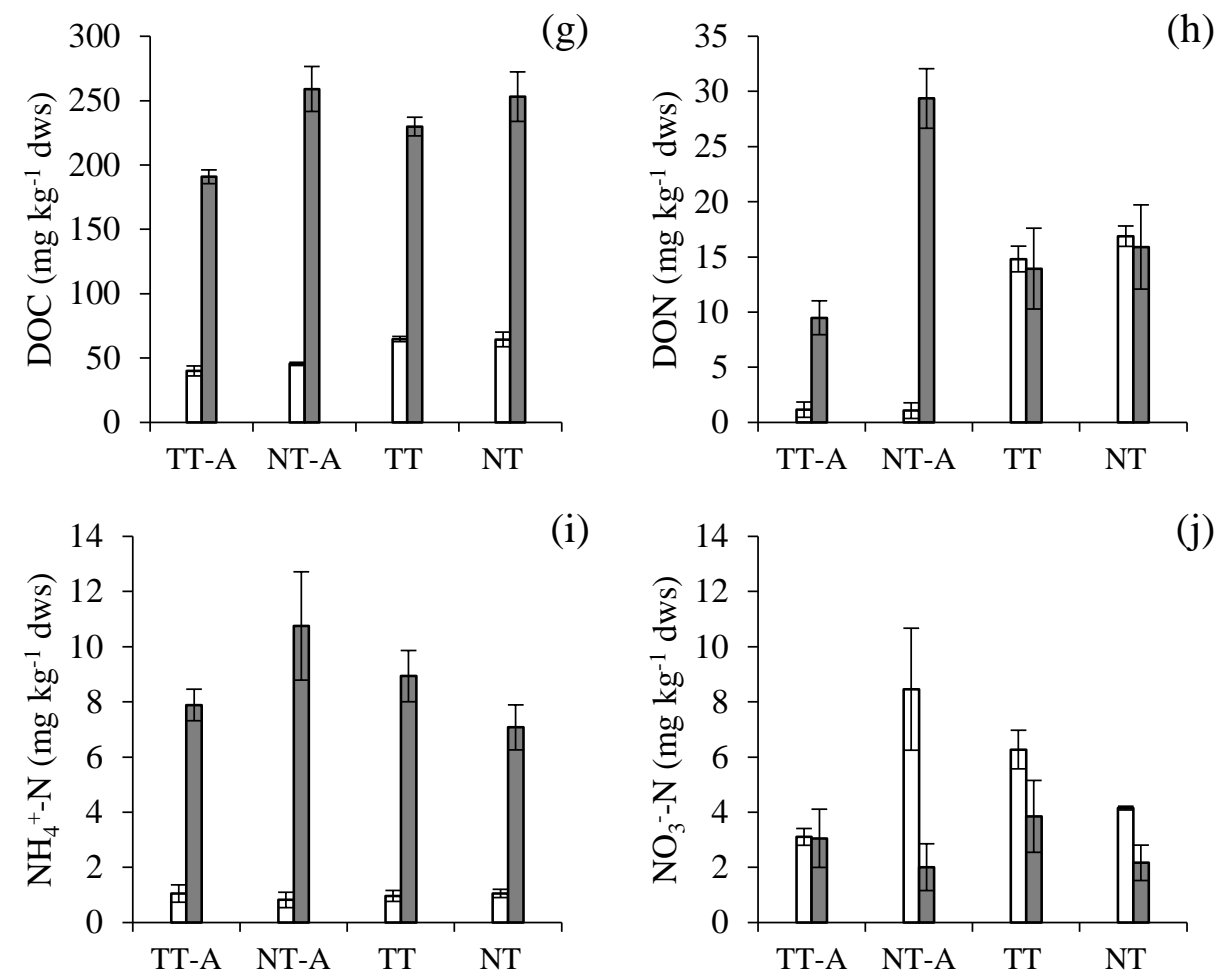

Fig. 4.2.2: Gross ammonification rate (a), gross nitrification rate (b), ammonium (c) and nitrate (d) immobilization rate, microbial biomass carbon (e), microbial biomass nitrogen (f), dissolved organic carbon (g), dissolved organic nitrogen (h), ammonium (i) and nitrate (j) content for both sampling dates. Bars represent standard errors $(n=4)$.

The abundance of 16S gene copies dropped between May and July from 18.7 $10^{10}$ gene copies $\mathrm{g}^{-1}$ to $1.310^{10}$ gene copies $\mathrm{g}^{-1}$. A similar pattern between treatments was found in both samplings: higher abundance in NT plots and enhancing effect of liming application, with higher differences between treatments in May (Fig. 4.2.3; Table 4.2.3). The abundance of ITS gene copies representing fungal populations decreased in time from $11.310^{8}$ gene copies $\mathrm{g}^{-1}$ to $2.310^{8}$ gene copies $\mathrm{g}^{-1}$. The lower reduction found in total ITS genes respect to the reduction of bacterial $16 \mathrm{~S}$ showed a significant increase of the ITS:16S ratio between May and July. Soil liming reduced the abundance of total soil fungi in May and July and the highest abundance was detected in NT plots not receiving amendment in May (Fig. 4.2.3; Table 4.2.3). Therefore, the ITS:16S ratio was significantly decreased by liming. 

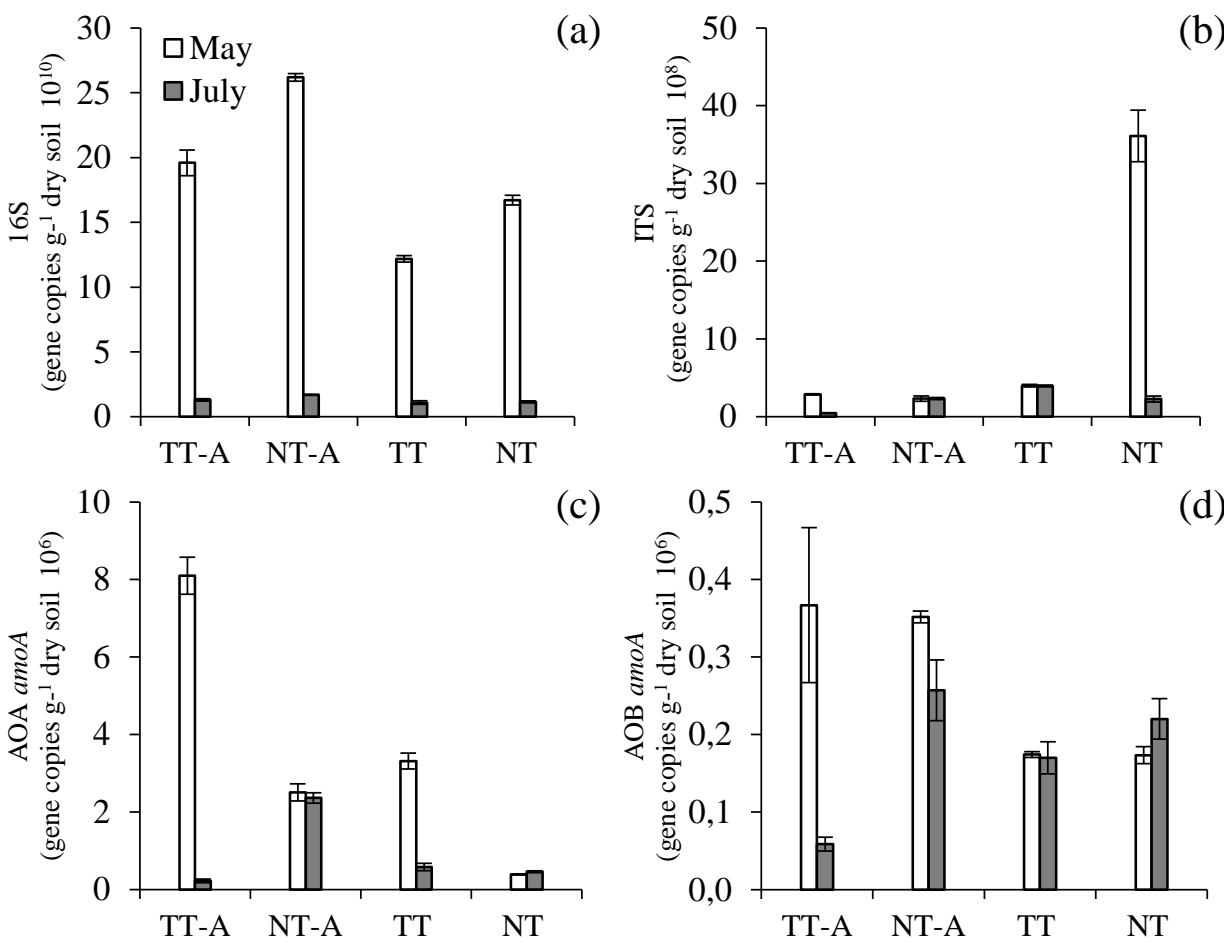

(d)

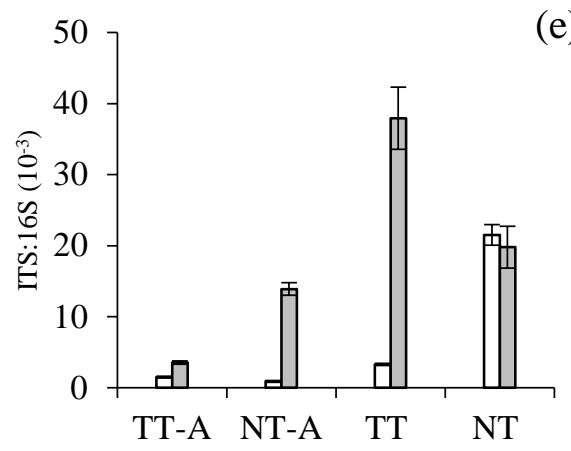

Fig. 4.2.3: The abundance of $16 \mathrm{~S}$ (a), ITS (b), AOA-amoA (c) and AOB-amoA (d) gene copies and the ITS:16S ratio (e) determined during both sampling events. Bars represent standard errors $(\mathrm{n}=4)$.

The abundance of AOA and AOB also decreased between the two samplings, from 3.58 to $0.9110^{6}$ gene copies $\mathrm{g}^{-1}$ and from 0.267 to $0.17710^{6}$ gene copies $\mathrm{g}^{-1}$, respectively (Fig. 4.2.3). Although the AOA abundance was overall higher in TT plots, the abundance was higher under TT in May but higher in NT plots in July. The amendment increased the AOA abundance with an interaction with the tillage practice increasing strongly the AOA abundance in the NT-A plots with respect to the NT (Fig. 4.2.3; Table 4.2.3). The abundance of AOB was increased by amendment in May and by tillage practice in July when it was higher in NT (Fig. 4.2.3; Table 4.2.3). 
Table 4.2.3: Effects of sampling time, tillage and amendment application on number of gene copies of 16S, ITS, AOA-amoA AOB-amoA and the ratio ITS:16S

\begin{tabular}{lccccc}
\hline & $16 \mathrm{~S}$ & ITS & $\begin{array}{r}\text { AOA- } \\
\text { amoA }\end{array}$ & $\begin{array}{c}\text { AOB- } \\
\text { amoA }\end{array}$ & ITS:16S \\
\hline Effects & $* * *$ & $* * *$ & $* * *$ & $* *$ & $* * *$ \\
$\mathrm{D}$ & $* * *$ & $* * *$ & $* * *$ & n.s. & n.s. \\
$\mathrm{T}$ & $* * *$ & $* * *$ & $* * *$ & $*$ & $* * *$ \\
$\mathrm{~A}$ & $* * *$ & $* * *$ & $* * *$ & $*$ & $* * *$ \\
\hline DxT & $* * *$ & $* * *$ & $* * *$ & $* * *$ & $* *$. \\
DxA & n.s. & $* * *$ & n.s. & n.s. & n.s. \\
TxA & n.s & $* * *$ & $* * *$ & n.s. & $* * *$ \\
DxTxA & & & &
\end{tabular}

$D$ sampling date; $T$ tillage; $A$ amendment

$* \mathrm{p}<0.05 ; * * \mathrm{p}<0.01 ; * * * \mathrm{p}<0.001 ;$ n.s. not significant

\subsubsection{Correlation and controls of gross $N$ transformations and microbiological parameters}

Gross mineralization, gross nitrification and $\mathrm{NH}_{4}{ }^{+}$immobilization rates were positively correlated with the WFPS $(\mathrm{R}=0.504, \mathrm{p}=0.003, \mathrm{R}=0.583, \mathrm{p}<0.001$ and $\mathrm{R}=0.646, \mathrm{p}<0.001$, respectively). The gross mineralization and $\mathrm{NH}_{4}{ }^{+}$immobilization rates seemed to be affected by soil bacteria as revealed by the bivariate correlation analyses $(\mathrm{R}=0.554, \mathrm{p}=0.001$ and $\mathrm{R}=0.723, \mathrm{p}<0.001$, respectively) and by stepwise regression analysis (Table 4.2.4). The gross nitrification rate was correlated with both AOA $(\mathrm{R}=0.525, \mathrm{p}=0.001)$ and $\mathrm{AOB}(\mathrm{R}=0.358, \mathrm{p}=0.044)$ although the nitrifier populations were not included in the stepwise regression where $\mathrm{pH}$ was identified as one of the main factors of gross nitrification (Table 4.2.4).

Table 4.2.4 Multiple regression analysis to identify the main factors affecting the $\mathrm{N}$ gross transformation and the abundance of nitrifiers. The values are constants or coefficients in the fitted equation $\mathrm{Y}=\mathrm{a}+\mathrm{bx}_{1}+\mathrm{cx}_{2}+\mathrm{dx}_{3} \ldots$ where $\mathrm{Y}$ is the dependent variable and $\mathrm{x}_{1}, \mathrm{x}_{2}, \mathrm{x}_{3} \ldots$ are the independent variables

\begin{tabular}{llllllllll}
\hline & $\begin{array}{l}\text { Const } \\
\text { ant }\end{array}$ & $16 \mathrm{~S}$ & WFPS & $\mathrm{NH}_{4}{ }^{+}$ & $\mathrm{NO}_{3}{ }^{-}$ & $\mathrm{pH}$ & $\mathrm{AOA}$ & $\mathrm{R}^{2}$ & $\begin{array}{l}\mathrm{p} \text {-value } \\
\text { (model) }\end{array}$ \\
\hline Gross ammon. & -1.42 & 0.09 & 0.04 & 0.26 & & & & 0.754 & $* * *$ \\
Gross nitr & -0.84 & & 0.02 & & -0.07 & 0.22 & & 0.544 & $* * *$ \\
$\mathrm{NH}_{4}{ }^{+}$immob & 0.74 & 0.18 & & & & & & 0.522 & $* * *$ \\
$\mathrm{NO}_{3}{ }^{-}$immob & 0.39 & & & & & & 0.136 & 0.166 & $*$ \\
\hline
\end{tabular}

Discarded parameters $(\mathrm{p}<0.05)$ were: SOC, TN, GWC, Dhase, DOC, DON MBC, MBN and AOB and ITS abundance. Gross Ammon. Gross ammonification; Gross Nitrif. Gross nitrification; $\mathrm{NH}_{4}{ }^{+}$immob. Ammonium immobilization; $\mathrm{NO}_{3}^{-}$immob. Nitrate immobilization.

$\mathrm{p}<0.05, * * \mathrm{p}<0.01, * * * \mathrm{p}<0.001$ 


\subsection{Experiment 3: Post re-wetting soil $\mathrm{N}_{2} \mathrm{O}$ emissions}

\subsubsection{Soil incubation and $\mathrm{N}_{2} \mathrm{O}$ emissions}

Soil was rewetted to 50 and $100 \%$ FC and the soils required 15 and 26 days respectively to dry again (Fig. 4.3.1). Soil rewetting stimulated the $\mathrm{N}_{2} \mathrm{O}$ emissions with a short-duration peak within the first $24 \mathrm{~h}$ after the rewetting event (Fig. 4.3.1) with very low fluxes during the rest of the incubation time. The highest $\mathrm{N}_{2} \mathrm{O}$ emissions were detected during the first two hours after rewetting and were slightly higher in the $50 \%$ FC than in $100 \% \mathrm{FC} \mathrm{(3.14} \mathrm{and} 2.20 \mu \mathrm{g} \mathrm{N}_{2} \mathrm{O} \mathrm{kg} \mathrm{soil}{ }^{-1} \mathrm{~h}^{-1}$, respectively) (Fig. 4.3.1). The emissions followed a similar pattern at both soil moisture levels despite the differences in the soil moisture; for example, the soils of $100 \%$ FC reached the soil moisture equivalent to $50 \%$ FC after approximately $360 \mathrm{~h}$ of incubation (Fig. 4.3.1).

Table 4.3.1: Cumulative $\mathrm{N}_{2} \mathrm{O}$ emissions of the four treatments at $50 \%$ and $100 \%$ of $\mathrm{FC}$ and the effect of moisture (50\% FC vs 100\% FC) tillage practice (NT vs TT) and Liming (amended vs. not amended) and their interactions.

\begin{tabular}{llc}
\hline & \multicolumn{2}{c}{${\mathrm{N}-\mathrm{N}_{2} \mathrm{O} \mathrm{mg} \mathrm{kg} \mathrm{soil}}^{-1}$} \\
& $50 \% \mathrm{FC}$ & $100 \% \mathrm{FC}$ \\
\hline TT-A & $12.64(1.04)$ & $16.35(0.91)$ \\
NT-A & $15.57(1.19)$ & $19.52(2.06)$ \\
TT & $38.18(3.60)$ & $44.39(7.68)$ \\
NT & $52.77(4.16)$ & $54.71(9.51)$ \\
\hline Effects & & \\
Moisture & & n.s. \\
Tillage & *** \\
Amendment & n.s. \\
Moisture x Tillage & n.s. \\
Moisture x Amendment & n.s. \\
Tillage x Amendment & n.s. \\
Moisture x Tillage x Amend & \\
\hline
\end{tabular}

Standard errors $(n=4)$ are reported in brackets

$*, * *, * * *$ indicate differences at $\mathrm{p}<0.05, \mathrm{p}<0.01$ and $\mathrm{p}<0.001$, respectively

n.s. not significant

Liming reduced the $\mathrm{N}_{2} \mathrm{O}$ emissions respect to the not amended control at both moisture levels while the tillage practice did not affect significantly the emissions (Fig. 4.3.1, Table 4.3.1). At 50\% FC, the cumulative $\mathrm{N}_{2} \mathrm{O}$ emissions of the liming amended treatments were $14.11 \mu \mathrm{g} \mathrm{N}-\mathrm{N}_{2} \mathrm{O} \mathrm{kg} \mathrm{soil}{ }^{-1}$ while in the non-ameded treatments they were $45.47 \mu \mathrm{g} \mathrm{N}-\mathrm{N}-\mathrm{N}_{2} \mathrm{O} \mathrm{kg}$ soil $^{-1}$. 

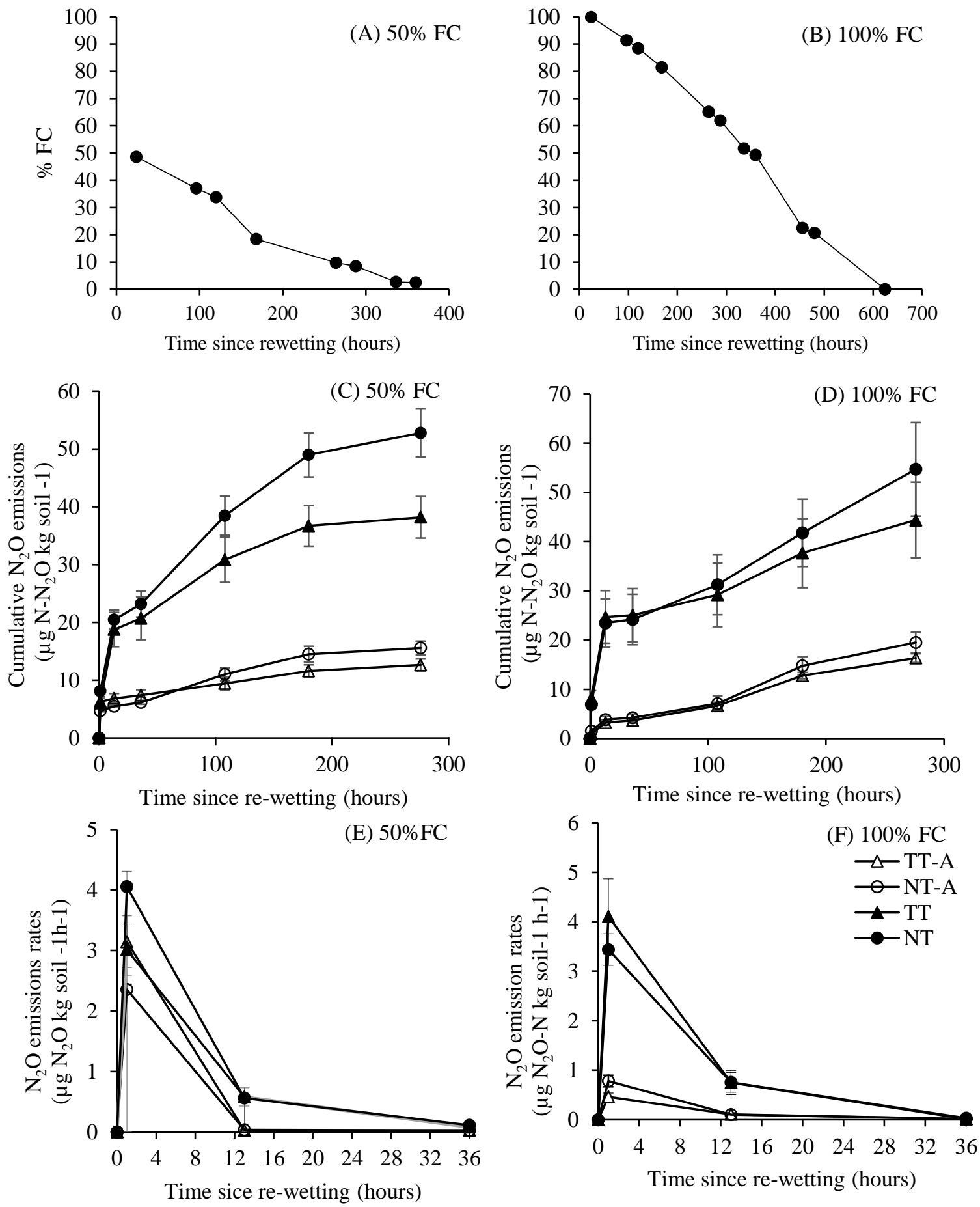

Fig. 4.3.1: Soil moisture evolution during the incubation study at $50 \%$ FC (A) and $100 \%$ FC (B) ${ }^{1}$, cumulative $\mathrm{N}_{2} \mathrm{O}$ emissions during the incubation period at $50 \% \mathrm{FC}$ (C) and $100 \% \mathrm{FC}$ (D), and $\mathrm{N}_{2} \mathrm{O}$ hourly fluxes during the first $36 \mathrm{~h}$ after rewetting at $50 \% \mathrm{FC}(\mathrm{E})$ and $100 \% \mathrm{FC}(\mathrm{F})$. Bars represents the standard error $(n=4) .{ }^{1}$ The data presented corresponds with the mean of the four treatments at each field capacity (FC) level. 
At $100 \%$ FC the cumulative emissions were 17.94 and $49.55 \mu \mathrm{g} \mathrm{N}-\mathrm{N}_{2} \mathrm{O} \mathrm{kg} \mathrm{soil}{ }^{-1}$, in amended and non-amended treatments, respectively. The cumulative emissions were statistically higher at $100 \%$ WHC than at 50\% WHC (Fig. 4.3.1, Table 4.3.1).

\subsubsection{Initial nitrifier and denitrifier populations}

The long-term application of a liming amendment strongly increased the size of nitrifiers and denitrifiers communities in soil (Fig. 4.3.2); AOB-amoA and nirK gene abundance were increased three times and $\operatorname{nos} Z$ gene abundance raised by $67 \%$ respect to the treatments without amendment. However, when compared to liming, the effect of tillage was weaker and only the nos $Z$ gene abundance was affected by the type of tillage with a $34 \%$ reduction in NT respect to TT.

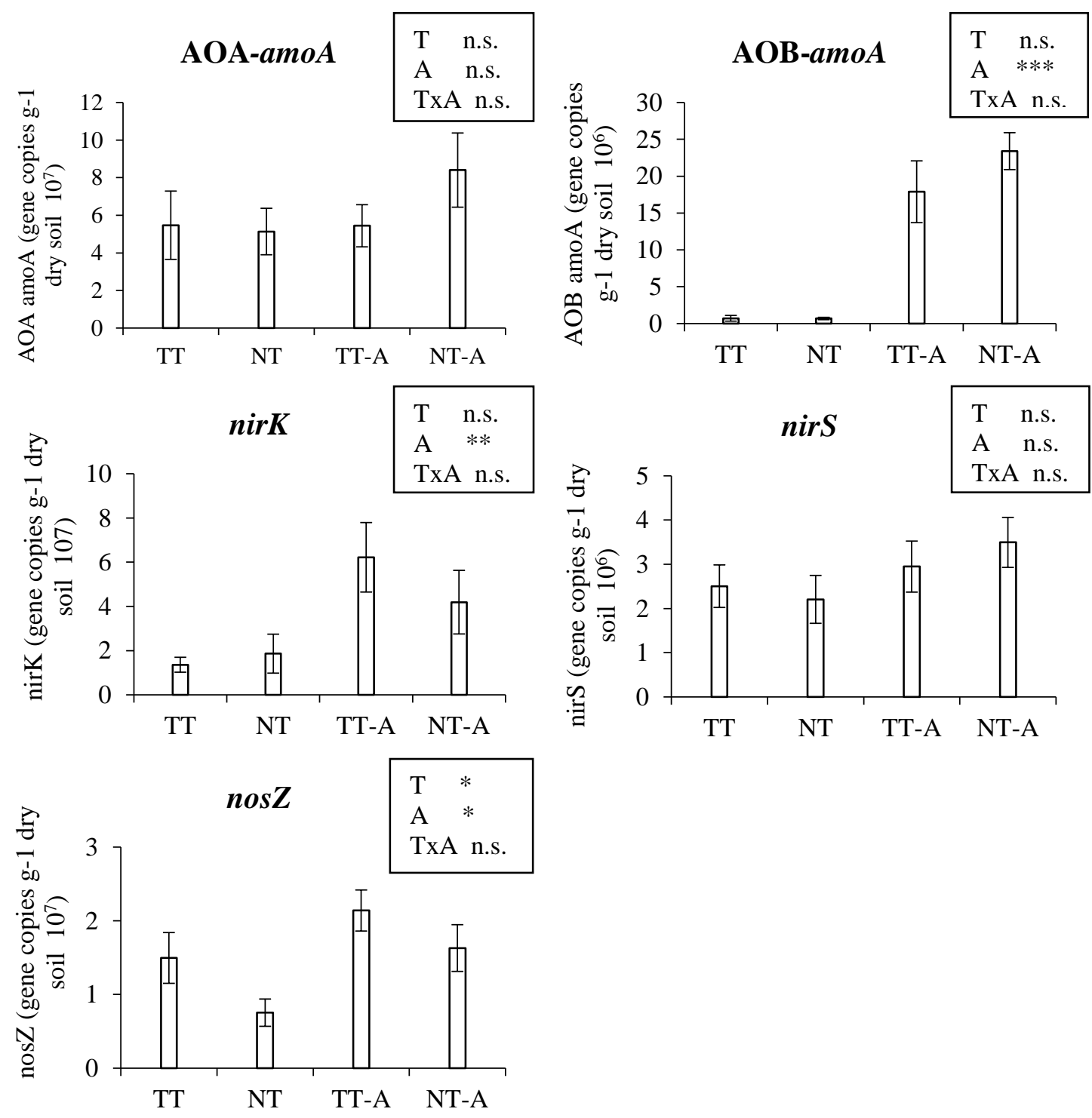

Fig 4.3.2: Nitrifiers and denitrifiers abundance in the initial soil reported as amoA, nirK, nirS, and nos $Z$ gene copy numbers per gram of dry soil. Bars represents standard error $(\mathrm{n}=4)$. TT, traditional tillage without liming amendment; NT, no tillage without liming amendment; TT-A, traditional tillage with 
liming amendment; NT-A, no tillage with liming amendment. The table located in the upper right corner shows the effect of tillage practice (T), amendment application (A) and their interaction (TxA) on gene copy numbers. $* * * \mathrm{p}<0.001, * * \mathrm{p}<0.0,1 * \mathrm{p}<0.05$, n.s. no significant differences.

Similarly, the nitrifiers and denitrifiers community structure and diversity were affected more by liming than by tillage practice. The evaluation of DGGE profiles showed that the limed amended treatments were clearly separated from the soils without amendment for the nirK, nirS and nos $Z$ gene bearing communities in the UPGMA and nMDS analysis (Fig 4.3.3). One-way ANOSIM and PERMANOVA revealed that liming affected the DGGE profiles of nirK and nirS gene bearing communities (Table 4.3.2). In addition, liming increased the richness and Shannon-Wiener diversity index of the nirS bearing denitrifiers (Table 4.3.3).

Table 4.3.2: ANOSIM and PERMANOVA global test based on the Dice similarity matrices derived from DGGE band profiles

\begin{tabular}{cccccc}
\hline & \multicolumn{2}{c}{ ANOSIM } & \multicolumn{3}{c}{ PERMANOVA } \\
Effects & T & A & T & A & TxA \\
\hline AOA-amoA & n.s. & n.s. & n.s. & n.s. & n.s. \\
AOB-amoA & $*$ & - & $*$ & - & - \\
nirK & n.s. & $* * *$ & n.s. & $* * *$ & n.s. \\
nirS & n.s. & $* *$ & n.s. & $* * *$ & n.s. \\
nos $Z$ & n.s. & n.s. & n.s. & $*$ & n.s. \\
\hline$*, * *, * * *$ indicate differences at $\mathrm{p}<0.05, \mathrm{p}<0.01$ and $\mathrm{p}<0.001$, respectively \\
n.s. not significant
\end{tabular}

Table 4.3.3: Average species richness and Shannon -Weiner diversity index calculated on DGGE band profiles of selected genes and effect of tillage practice (T), amendment (A) and their interaction.

\begin{tabular}{ccccccccccc}
\hline & AOA-amoA & \multicolumn{2}{c}{ AOB-amoA } & \multicolumn{2}{c}{ nirK } & \multicolumn{3}{c}{ nirS } & nosZ \\
\hline & Rich & Shan & Rich & Shan & Rich & Shan & Rich & Shan & Rich & Shan \\
\hline TT-A & 8.0 & 1.99 & $5.0^{\mathrm{b}}$ & $1.49^{\mathrm{b}}$ & 11.8 & 2.45 & 17.5 & 2.84 & 14.3 & 2.55 \\
NT-A & 9.3 & 2.17 & $7.5^{\mathrm{a}}$ & $1.87^{\mathrm{a}}$ & 11.8 & 2.44 & 14.0 & 2.61 & 13.5 & 2.57 \\
TT & 8.5 & 2.07 & - & - & 12.3 & 2.48 & 8.8 & 2.12 & 13.5 & 2.48 \\
NT & 9.0 & 2.12 & - & - & 13.8 & 2.58 & 9.0 & 2.16 & 15.3 & 2.57 \\
\hline T & n.s. & n.s. & - & - & n.s. & n.s. & n.s. & n.s. & n.s. & n.s. \\
A & n.s. & n.s. & - & - & n.s. & n.s. & $* * *$ & $* * *$ & n.s. & n.s. \\
TxA & n.s. & n.s. & - & - & n.s. & n.s. & n.s. & n.s. & n.s. & n.s. \\
\hline
\end{tabular}

$*, * *, * * *$ indicate differences at $\mathrm{p}<0.05, \mathrm{p}<0.01$ and $\mathrm{p}<0.001$, respectively

n.s. not significant 


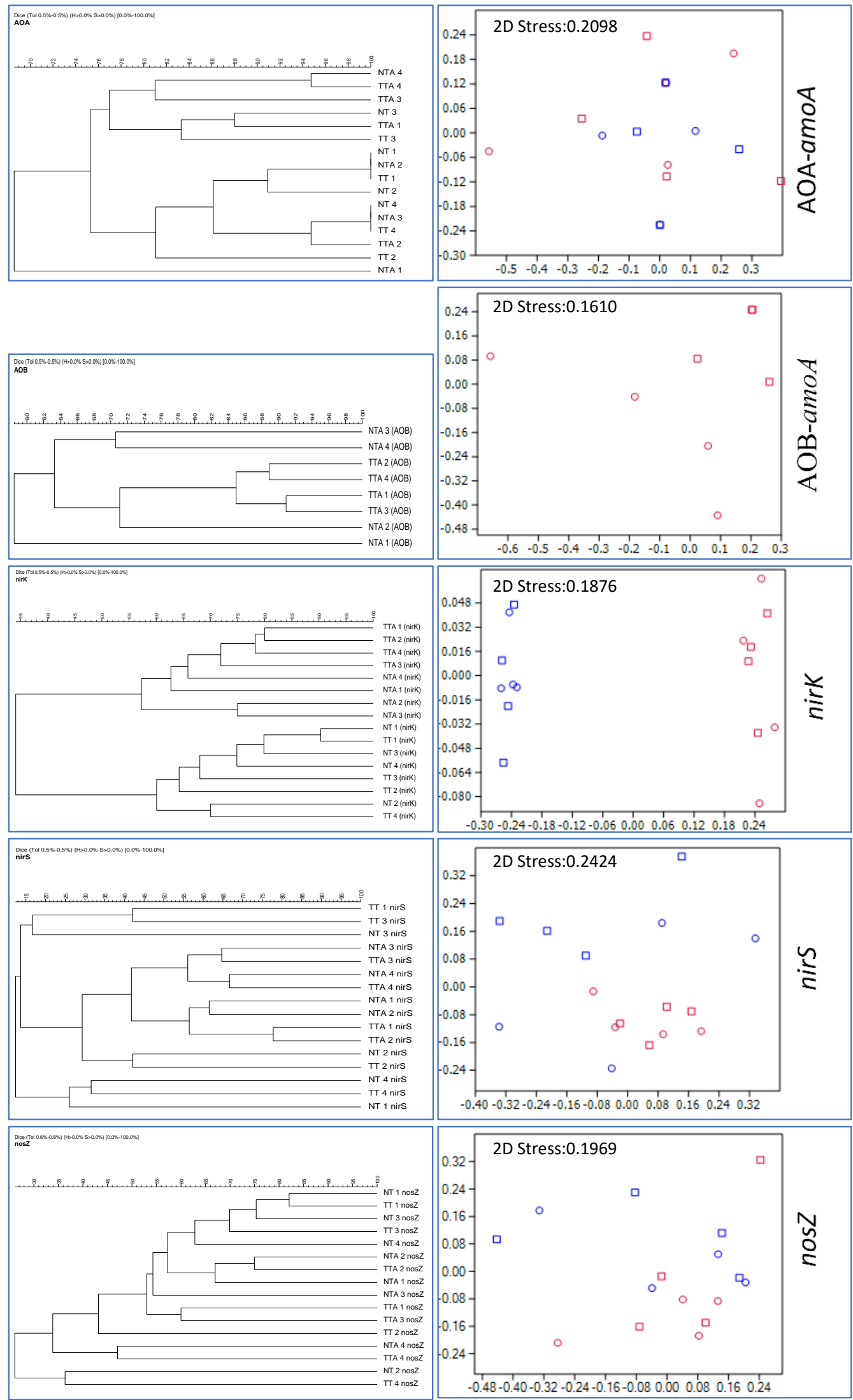

Fig 3: UPGMA and nMDS analysis of AOA-amoA, AOB-amoA, nirK, nirS and nosZ gene DGGE profiles obtained from the initial soil. TT (blue squares), traditional tillage without liming amendment; NT (blue circles), no tillage without liming amendment; TT-A (red squares), traditional tillage with liming amendment; NT-A (red circles), no tillage with liming amendment). 
In the case of AOB-amoA communities, only the structure of liming amended treatments is presented because no visible gel-bands were amplified in the soils without amendment even after several attempts (Fig. 4.3.3). However, in the AOB-amoA DGGE profiles of NT-A and TT-A, we observed a significative increase of the richness and Shannon-Wiener diversity index in NT-A respect to TT-A $(\mathrm{p}<0.05)$ (Table 4.3.3) and a significant effect of tillage practices was revealed by graphical representations (UPGMA and nMDS) and multivariate statistical analysis (ANOSIM and PERMANOVA). The diversity of AOA-amoA community was not affected by tillage or by liming.

\subsubsection{Nitrifier and denitrifier transcription}

No significant gene transcription was found in the nitrifiers populations after soil rewetting as the AOA-amoA and AOB-amoA gene cDNA copy numbers were bellow or near the qPCR detention limit (data not shown). Similarly, no significant gene trascription of nirS and nosZ genes was observed. On the other hand, the nirK-bearing community showed a significant gene expression upon rewetting (Fig. 4.3.5). The nirK expression was found at both sampling times and moisture levels, but no significant differences in the nirK gene cDNA number of copies were found between both moisture levels (Fig. 4.3.4, Table 4.3.4). However, liming increased significantly the nirK gene cDNA copy number at $2 \mathrm{~h}$ and $24 \mathrm{~h}$ after rewetting (Fig. 4, Table 4.3.5).

Table 4.3.4: Effect of moisture, M (50\% FC vs $100 \%$ FC) tillage practice, $\mathrm{T}$ (NT vs TT) and liming, A (amended vs. not amended) and their interactions on the abundance of nirK gene cDNA.

\begin{tabular}{|c|c|c|}
\hline & \multicolumn{2}{|c|}{ cDNA nirK } \\
\hline & $2 \mathrm{~h}$ & $24 \mathrm{~h}$ \\
\hline $\mathrm{M}$ & n.s. & n.s. \\
\hline $\mathrm{T}$ & n.s. & n.s. \\
\hline A & $* *$ & $* * *$ \\
\hline $\mathrm{M} \times \mathrm{T}$ & n.s. & $*$ \\
\hline $\mathrm{M} \times \mathrm{A}$ & n.s. & $*$ \\
\hline $\mathrm{T} \times \mathrm{A}$ & n.s. & n.s. \\
\hline $\mathrm{M} \times \mathrm{T} \times \mathrm{A}$ & n.s. & n.s. \\
\hline
\end{tabular}

Two hours after rewetting to $50 \%$ FC, the nirK gene cDNA of liming amended treatments reached $36 \times 10^{6}$ gene copies $\mathrm{g}^{-1}$ dry soil while in the treatments without amendment, the average was $6.3 \times 10^{6}$ copies $\mathrm{g}^{-1}$ dry soil (Fig. 4.3.4). Similarly, at $\mathrm{t}_{24 \mathrm{~h}}$, the nirK gene cDNA abundance was $40.9 \times 10^{6}$ and $2.8 \times 10^{6}$ copies $\mathrm{g}^{-1}$ dry soil for liming 
amended and without amendment treatments, respectively. At $100 \% \mathrm{FC}$, the nirK gene cDNA abundance in limed and control soils was $45.7 \times 10^{6}$ and $6 \times 10^{6}$ copies $\mathrm{g}^{-1}$ dry soil at $\mathrm{t}_{2 \mathrm{~h}}$, and $25.5 \times 10^{6}$ and $6.146 \times 10^{6}$ gene copies $\mathrm{g}^{-1}$ dry soil at $\mathrm{t}_{24 \mathrm{~h}}$, respectively. Similarly, at $\mathrm{t}_{24 \mathrm{~h}}$ the interaction of Moisture $\mathrm{x}$ Tillage revealed that at $50 \% \mathrm{FC}$, the TT was higher than NT while at $100 \%$ of FC both treatments were comparable (Fig. 4.3.4, Table 4.3.4). In addition, although the interaction Tillage $\mathrm{x}$ Amendment was no significant $(\mathrm{p}=0.061)$, the effect of liming amendment was higher in TT than in NT.
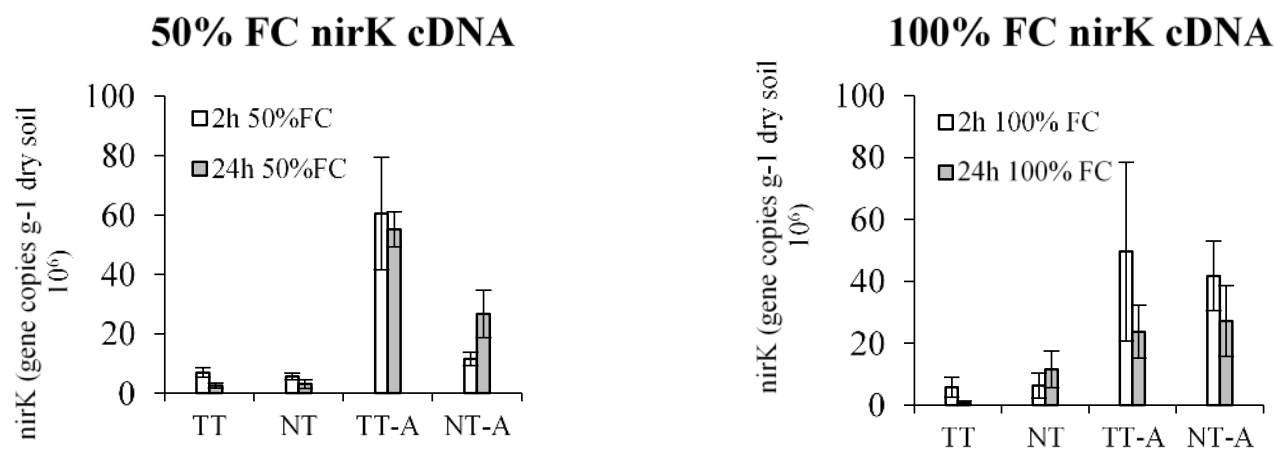

Fig. 4.3.4: nirK gene expression reported as nirK gene cDNA copy number per gram of dry soil after $2 \mathrm{~h}$ and $24 \mathrm{~h}$ of soil rewetting at 50\% FC and 100\% FC. Bars represents standard error ( $\mathrm{n}=4)$. TT, traditional tillage without liming amendment; NT, no tillage without liming amendment; TT-A, traditional tillage with liming amendment; NT-A, no tillage with liming amendment). FC, field capacity 


\subsection{Experiment 4: Effects of NT and liming on carbon and nitrogen mineralization}

\subsubsection{Soil chemical properties}

No-tillage increased the contents of all $\mathrm{C}$ and $\mathrm{N}$ fractions but this effect was constrained to the upper soil layer (Table 4.4.1). The most responsive $\mathrm{C}$ fraction to NT in the top soil layer was POM with an increase of $51 \%$ when compared to TT. The liming amendment increased soil $\mathrm{pH}, \mathrm{Ca}$ and $\mathrm{Mg}$ contents and this effect was stronger in the upper soil layer. Moreover, both $\mathrm{Ca}$ and $\mathrm{Mg}$ were significantly higher in the NT plots and the effect was stronger in the upper layer (Table 4.4.1).

Table 4.4.1. The effects of soil depth (Dpt), tillage (T) and amendment (A) on organic matter and soil carbon fractions, soil $\mathrm{pH}$ and base cations

\begin{tabular}{|c|c|c|c|c|c|c|c|c|c|c|}
\hline \multirow[t]{2}{*}{ Depth } & \multirow[t]{2}{*}{ Treatment } & SOM & SOC & $\mathrm{TN}$ & POM & $\mathrm{POxC}$ & \multirow{2}{*}{$\begin{array}{l}\mathrm{pH} \\
\mathrm{H}_{2} \mathrm{O}\end{array}$} & \multirow[b]{2}{*}{$\mathrm{KCl}$} & $\mathrm{Ca}^{+2}$ & $\mathrm{Mg}^{2+}$ \\
\hline & & \multicolumn{5}{|l|}{$\left(\mathrm{g} \mathrm{kg}^{-1}\right)$} & & & \multicolumn{2}{|l|}{$\left(\mathrm{g} \mathrm{kg}^{-1}\right)$} \\
\hline \multirow[t]{4}{*}{$0-5 \mathrm{~cm}$} & TT & 60.7 & 32.8 & 1.70 & 18.0 & 0.92 & 4.00 & 3.40 & 0.25 & 25.7 \\
\hline & TT-A & 64.2 & 35.1 & 1.85 & 19.4 & 1.10 & 5.95 & 5.63 & 2.00 & 48.2 \\
\hline & NT & 82.6 & 42.6 & 2.37 & 26.7 & 1.28 & 4.48 & 3.69 & 0.66 & 52.8 \\
\hline & NT-A & 84.8 & 44.2 & 2.55 & 29.6 & 1.29 & 5.98 & 5.61 & 2.43 & 63.0 \\
\hline \multirow[t]{4}{*}{$5-10 \mathrm{~cm}$} & $\mathrm{TT}$ & 63.8 & 33.5 & 1.63 & 13.4 & 0.80 & 4.30 & 3.56 & 0.15 & 16.0 \\
\hline & TT-A & 67.8 & 33.3 & 1.68 & 14.9 & 0.93 & 5.19 & 4.42 & 1.10 & 28.4 \\
\hline & NT & 68.0 & 33.0 & 1.60 & 14.2 & 0.86 & 4.23 & 3.51 & 0.20 & 16.1 \\
\hline & NT-A & 68.0 & 33.6 & 1.68 & 15.2 & 0.88 & 4.85 & 4.1 & 1.05 & 28.7 \\
\hline \multirow[t]{7}{*}{ Effects } & $\mathrm{D}$ & $* * *$ & $* * *$ & $* * *$ & $* * *$ & $* * *$ & $* *$ & $* * *$ & $* * *$ & $* * *$ \\
\hline & $\mathrm{Tl}$ & $* *$ & $* *$ & $* *$ & $* * *$ & $* * *$ & n.s. & n.s. & $*$ & $* * *$ \\
\hline & A & n.s. & n.s. & n.s. & n.s. & n.s. & $* * *$ & $* * *$ & $* * *$ & $* * *$ \\
\hline & $\mathrm{D} \times \mathrm{T}$ & $* * *$ & $* * *$ & $* * *$ & $* * *$ & $* *$ & $*$ & n.s. & $*$ & $* * *$ \\
\hline & $\mathrm{D} \times \mathrm{A}$ & n.s. & n.s. & n.s. & n.s. & n.s. & $* * *$ & $* * *$ & $* * *$ & n.s. \\
\hline & $\mathrm{T} \times \mathrm{A}$ & n.s. & n.s. & n.s. & n.s. & n.s. & n.s. & n.s. & n.s. & n.s. \\
\hline & $\mathrm{D} \times \mathrm{T} \times \mathrm{A}$ & n.s. & n.s. & n.s. & n.s. & n.s. & n.s. & n.s. & n.s. & n.s. \\
\hline
\end{tabular}

TT, traditional tillage; TT-Ca, traditional tillage with amendment application; NT, no tillage; NT-Ca, no tillage with amendment application

SOM, soil organic matter; SOC, soil total organic carbon; TN, total nitrogen; POM, particulate organic matter; POxC, permanganate oxidizable carbon.

$* \mathrm{p}<0.05, * * \mathrm{p}<0.01, * * * \mathrm{p}<0.001$, n.s. not significant.

\subsubsection{Soil microbiological indicators}

All the microbiological indicators were higher in the upper layer (Table 4.4.2) which was more evident in NT plots. The abundance of both soil bacteria and fungi was increased by NT. On the other hand, the effect of amendment was rather inconsistent: the amendment increased Gmean, decreased the MBC by $18 \%$ and increased the MBN in the top layer (Table 2). The effect of amendment on total amount of bacteria and fungi was weak revealing a slight increase in the TT-Ca respect to the TT and a slight decrease of NT-Ca respect to NT (Table 4.4.2) as observed in the tillage-amendment 
interaction. The F:B ratio was strongly affected by soil depth with higher values in the 5-10 cm layer when compared to the topsoil (Table 4.4.2).

Table 4.4.2. The effects of depth (D), tillage (T) and amendment (A) on microbial indicators

\begin{tabular}{|c|c|c|c|c|c|c|c|}
\hline \multirow[t]{2}{*}{ Depth } & \multirow[t]{2}{*}{ Treatment } & $\mathrm{MBC}$ & $\mathrm{MBN}$ & \multirow[t]{2}{*}{ Gmean } & \multirow{2}{*}{$\begin{array}{l}\text { ITS } \\
\text { (gene copies } \\
\mathrm{g}^{-1} \text { dry soil } \\
\left.10^{6}\right)\end{array}$} & \multirow{2}{*}{$\begin{array}{l}16 \mathrm{~S} \\
\text { (gene } \\
\text { copies } \mathrm{g}^{-1} \\
\text { dry soil } 10^{9} \text { ) } \\
\end{array}$} & \multirow{2}{*}{$\begin{array}{l}F: B \\
\left(10^{-3}\right)\end{array}$} \\
\hline & & \multicolumn{2}{|c|}{$\left(\mathrm{mg} \mathrm{kg}^{-1}\right)$} & & & & \\
\hline \multirow[t]{4}{*}{$0-5 \mathrm{~cm}$} & $\mathrm{TT}$ & 474 & 89.1 & 47.5 & 4.53 & 1.29 & 4.76 \\
\hline & TT-A & 420 & 156 & 79.4 & 6.48 & 1.34 & 3.81 \\
\hline & NT & 616 & 170 & 80.2 & 24.7 & 3.02 & 4.36 \\
\hline & NT-A & 531 & 145 & 112 & 19.0 & 2.63 & 4.33 \\
\hline \multirow[t]{4}{*}{$5-10 \mathrm{~cm}$} & $\mathrm{TT}$ & 439 & 95.6 & 35.1 & 2.29 & 0.50 & 8.84 \\
\hline & TT-A & 347 & 69.4 & 49.5 & 4.47 & 1.14 & 7.30 \\
\hline & NT & 431 & 60.5 & 28.5 & 2.45 & 0.28 & 6.93 \\
\hline & NT-A & 315 & 53.2 & 42.5 & 3.05 & 0.41 & 9.35 \\
\hline \multirow[t]{7}{*}{ Effects } & $\mathrm{D}$ & $* * *$ & $* * *$ & $* * *$ & $* * *$ & $* * *$ & $* * *$ \\
\hline & $\mathrm{T}$ & $* * *$ & n.s. & $* *$ & $* * *$ & $* * *$ & n.s. \\
\hline & A & $* * *$ & n.s. & $* * *$ & n.s. & n.s. & n.s. \\
\hline & $\mathrm{D} \times \mathrm{T}$ & $* * *$ & $* * *$ & $* * *$ & $* * *$ & $* * *$ & n.s. \\
\hline & $\mathrm{D} \times \mathrm{A}$ & n.s. & $* *$ & $* * *$ & n.s. & $*$ & n.s. \\
\hline & $\mathrm{T} \times \mathrm{A}$ & n.s. & $* *$ & n.s. & $*$ & $*$ & n.s. \\
\hline & $\mathrm{D} \times \mathrm{T} \times \mathrm{A}$ & n.s. & $* * *$ & n.s. & n.s. & n.s. & n.s. \\
\hline
\end{tabular}

TT, traditional tillage; TT-Ca, traditional tillage with amendment application; NT, no tillage; NT-Ca, no tillage with amendment application.

MBC, microbial biomass C; MBN, microbial biomass N;; Gmean, geometric mean of the assayed enzymes; $\mathrm{F}: \mathrm{B}$, fungi-to-bacteria ratio.

$* \mathrm{p}<0.05, * * \mathrm{p}<0.01, * * * \mathrm{p}<0.001$, n.s. not significant.

\subsubsection{Carbon and nitrogen mineralization}

The cumulative soil $\mathrm{C}$ mineralization was four-times higher in the $0-5 \mathrm{~cm}$ layer than in the 5-10 cm layer (Fig. 4.4.1, Table 4.4.3). The peak of $\mathrm{CO}_{2}$ emissions was observed within the first six days of incubation. Carbon mineralization was $40 \%$ higher in the NT treatment than in the TT (Fig. 4.4.1, Table 4.4.3). The first order equation model provided an adequate description of the $\mathrm{C}$ mineralization and all the $\mathrm{R}^{2}$ ranged between 0.96 and 0.99 . The $C_{o}$ strongly decreased with soil depth (Table 4.4.3), the mineralization rate $k$ was higher in the $5-10 \mathrm{~cm}$ layer whereas $C_{o} k$ was higher in the top soil and in the NT plots (Table 4.4.3).

The amount of inorganic $\mathrm{N}$ in the topsoil layer followed a constant rising trend

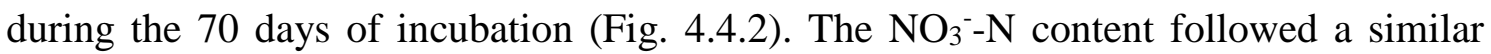
pattern while the $\mathrm{NH}_{4}{ }^{+}-\mathrm{N}$ dropped between the start of the incubation and the $17^{\text {th }}$ day (Fig. 4.4.2). The NNM and NN were significantly higher in the upper soil layer, in NT and in amended plots (Table 4.4.3). 
Table 4.4.3. The effects of depth (D), tillage (T) and amendment (A) on soil C mineralization and net $\mathrm{N}$ mineralization

\begin{tabular}{|c|c|c|c|c|c|c|c|}
\hline & & $\begin{array}{l}\text { Cumulative } \\
\mathrm{CO}_{2} \\
\text { production }\end{array}$ & $C_{o}$ & $k$ & $C_{o} k$ & $\begin{array}{l}\text { Net } \quad \mathrm{N} \\
\text { mineralization }\end{array}$ & $\begin{array}{l}\text { Net } \\
\text { nitrification }\end{array}$ \\
\hline & & $\left(\mathrm{mg} \mathrm{C} \mathrm{g}^{-1}\right)$ & $\begin{array}{l}\left(\mathrm{mg} \mathrm{C} \mathrm{g}^{-}\right. \\
\left.{ }^{1}\right)\end{array}$ & $\left(\right.$ day $\left.^{-1}\right)$ & $\begin{array}{lll}(\mathrm{mg} & \mathrm{C} & \mathrm{g}^{-1} \\
\left.\text { day }^{-1}\right) & & \end{array}$ & $\begin{array}{ll}\left(\begin{array}{l}\mathrm{mg} \\
\left.\text { day }^{-1}\right)\end{array}\right. & \mathrm{N} \\
\end{array}$ & $\begin{array}{l}\left(\mathrm{mg} \mathrm{N}^{\mathrm{N} \mathrm{NO}_{3}}{ }^{-1}\right. \\
\left.\mathrm{kg}^{-1} \mathrm{day}^{-1}\right)\end{array}$ \\
\hline \multirow[t]{4}{*}{$0-5 \mathrm{~cm}$} & TT & 0.64 & 1.04 & 0.014 & 0.014 & 0.82 & 0.83 \\
\hline & TT-a & 0.59 & 0.72 & 0.024 & 0.016 & 1.26 & 1.29 \\
\hline & NT & 1.08 & 1.94 & 0.013 & 0.023 & 1.28 & 1.41 \\
\hline & NT-A & 0.96 & 1.12 & 0.023 & 0.026 & 1.63 & 1.72 \\
\hline \multirow[t]{4}{*}{$5-10 \mathrm{~cm}$} & $\mathrm{TT}$ & 0.29 & 0.37 & 0.024 & 0.008 & 0.28 & 0.28 \\
\hline & TT-A & 0.29 & 0.32 & 0.028 & 0.009 & 0.45 & 0.45 \\
\hline & NT & 0.25 & 0.29 & 0.026 & 0.007 & 0.39 & 0.39 \\
\hline & NT-A & 0.28 & 0.37 & 0.022 & 0.008 & 0.47 & 0.47 \\
\hline \multirow[t]{7}{*}{ Effects } & $\mathrm{D}$ & $* * *$ & $* * *$ & $*$ & $* * *$ & $* * *$ & $* * *$ \\
\hline & $\mathrm{T}$ & $* * *$ & $* *$ & n.s. & $* *$ & $*$ & $*$ \\
\hline & A & n.s. & $* *$ & n.s. & n.s. & $*$ & $*$ \\
\hline & $\mathrm{D} \times \mathrm{T}$ & $* * *$ & $* *$ & n.s. & $* * *$ & n.s. & n.s. \\
\hline & $\mathrm{D} \times \mathrm{A}$ & n.s. & $* *$ & n.s. & n.s. & n.s. & n.s. \\
\hline & $\mathrm{T} \times \mathrm{A}$ & n.s. & n.s. & n.s. & n.s. & n.s. & n.s. \\
\hline & $\begin{array}{llll}\text { D } & x & T & x \\
\text { A } & & & \\
\end{array}$ & n.s. & n.s. & n.s. & n.s. & n.s. & n.s. \\
\hline
\end{tabular}

TT, traditional tillage; TT-Ca, traditional tillage with amendment application; NT, no tillage; NT-Ca, no tillage with amendment application; $C_{o}$, potentially mineralizable $\mathrm{C} ; k, \mathrm{C}$ mineralization constant; $C_{o} k$, initial potential $\mathrm{C}$ mineralization rate.

$* \mathrm{p}<0.05, * * \mathrm{p}<0.01, * * * \mathrm{p}<0.001$, n.s. not significant.
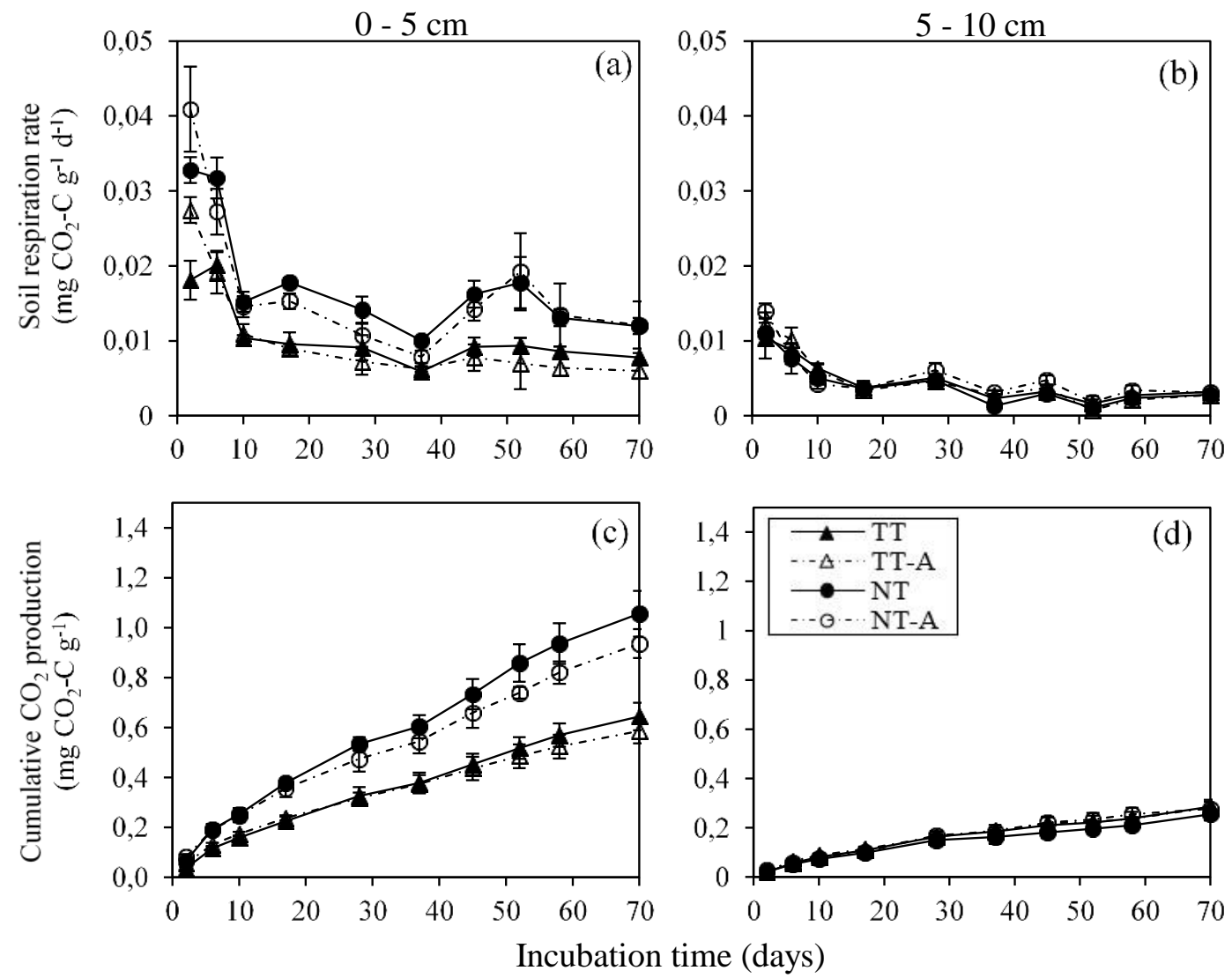

Fig. 4.4.1. Soil respiration $(\mathrm{a}, \mathrm{b})$ and cumulative $\mathrm{CO}_{2}-\mathrm{C}$ production $(\mathrm{c}, \mathrm{d})$ of $0-5 \mathrm{~cm}(\mathrm{a}, \mathrm{c})$ and $5-10 \mathrm{~cm}(\mathrm{~b}$, d) soil layer. Bars represent standard errors $(n=4)$. TT - traditional tillage; TT-A - traditional tillage with liming amendment; NT - no tillage; NT-A - no tillage with liming amendment. 

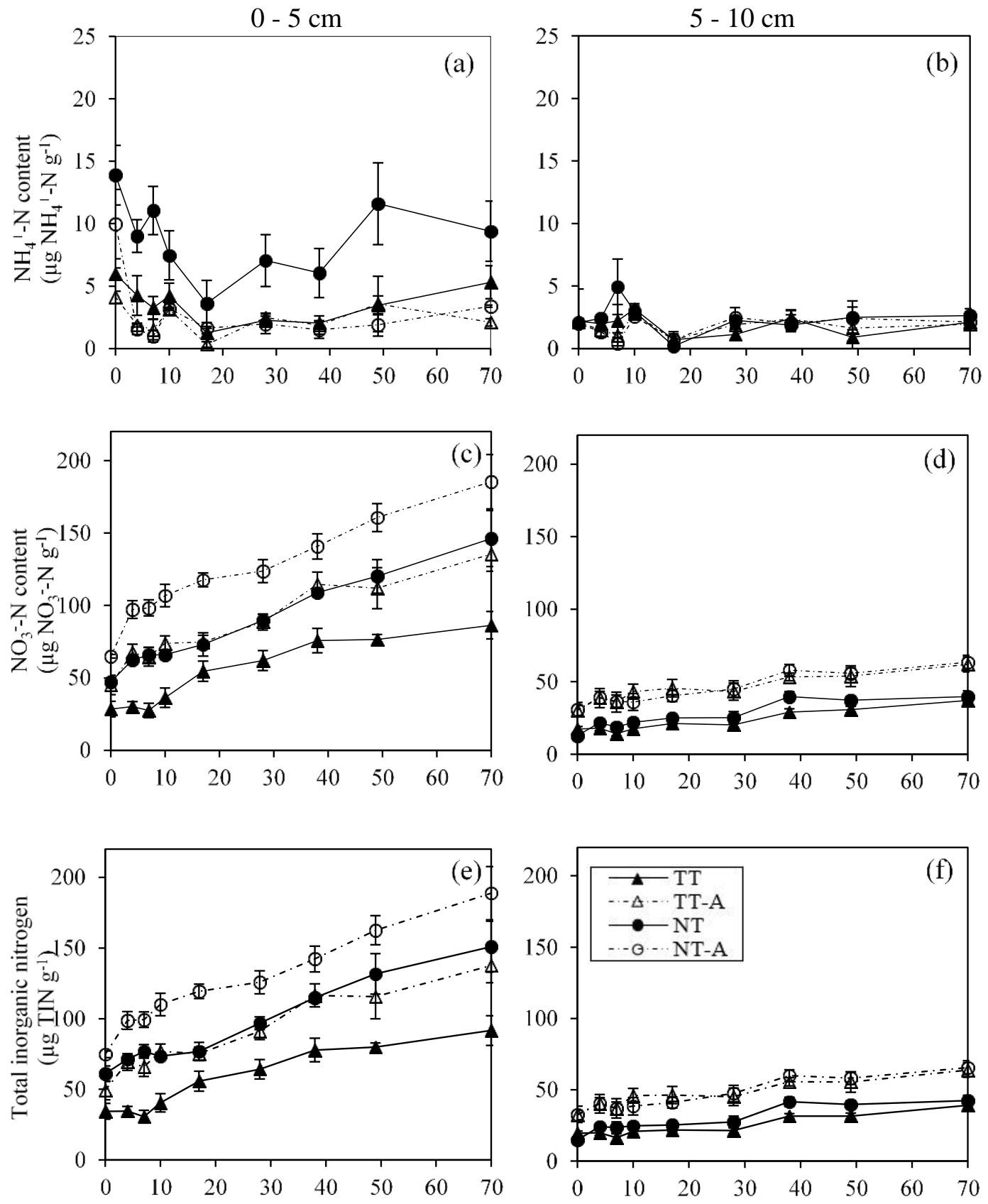

Incubation time (days)

Fig. 4.4.2. The contents of $\mathrm{NH}_{4}{ }^{+}-\mathrm{N}(\mathrm{a}, \mathrm{b}), \mathrm{NO}_{3}{ }^{-}-\mathrm{N}(\mathrm{c}, \mathrm{d})$ and total inorganic nitrogen (TIN) (e, f) ) of 0$5 \mathrm{~cm}(\mathrm{a}, \mathrm{c}, \mathrm{e})$ and $5-10 \mathrm{~cm}(\mathrm{~b}, \mathrm{~d}, \mathrm{f})$ soil layer. Bars represent standard errors $(\mathrm{n}=4)$. TT - traditional tillage; TT-Ca - traditional tillage with amendment application; NT - no tillage; NT-Ca - no tillage with amendment application.

\subsubsection{Relationships among variables}

Structural equation model $\left(\chi^{2}=19.282, \mathrm{p}=0.439, \mathrm{df}=19, \chi^{2} / \mathrm{df}=1.015, \mathrm{CFI}=0.999\right.$, $\mathrm{RMSEA}=0.022$, SRMR=0.0280) explained $81 \%$ of the $\mathrm{C}$ mineralization variation (represented by $C_{o} k$ ) and $79 \%$ of NNM variation (Fig. 4.4.3). Both agricultural practices 
(latent variables Tillage and Amendment) were significantly correlated between them (standardized pathway 0.56). The latent variable Tillage had a strong effect on MBC, Gmean and F:B (standardized pathways $0.92,0.69$ and -0.57 , respectively) while the latent variable Amendment influenced the $\mathrm{MBC}$ and Gmean (-0.58 and 0.36, respectively) but not the F:B whose pathway was non-significant. Direct pathways between Tillage and C mineralization or NNM were not significant, while Amendment affected directly NNM (standardized pathway 0.59). Considering the microbial parameters, both $\mathrm{C}$ and $\mathrm{N}$ mineralization were significantly affected by $\mathrm{MBC}$ (standardized pathways 0.51 and 0.44 , respectively).

The standardized total effects showed that $\mathrm{C}$ mineralization was more affected by Tillage when compared to Amendment (0.81 vs 0.08 , standardized total effects). In the case of NNM, the total effect of Tillage was also higher than the effect of Amendment although the differences were lower (0.65 and 0.28 for the Tillage and Amendment, respectively). Nevertheless, while the standardized direct effects of Tillage on $\mathrm{C}$ mineralization and NNM were non-significant, the indirect effects were very strong (0.69 and 0.43 the standardized indirect effects, respectively). The standardized direct effects of Amendment on NNM were positive (0.59) while the indirect effects were negative (-0.30). 


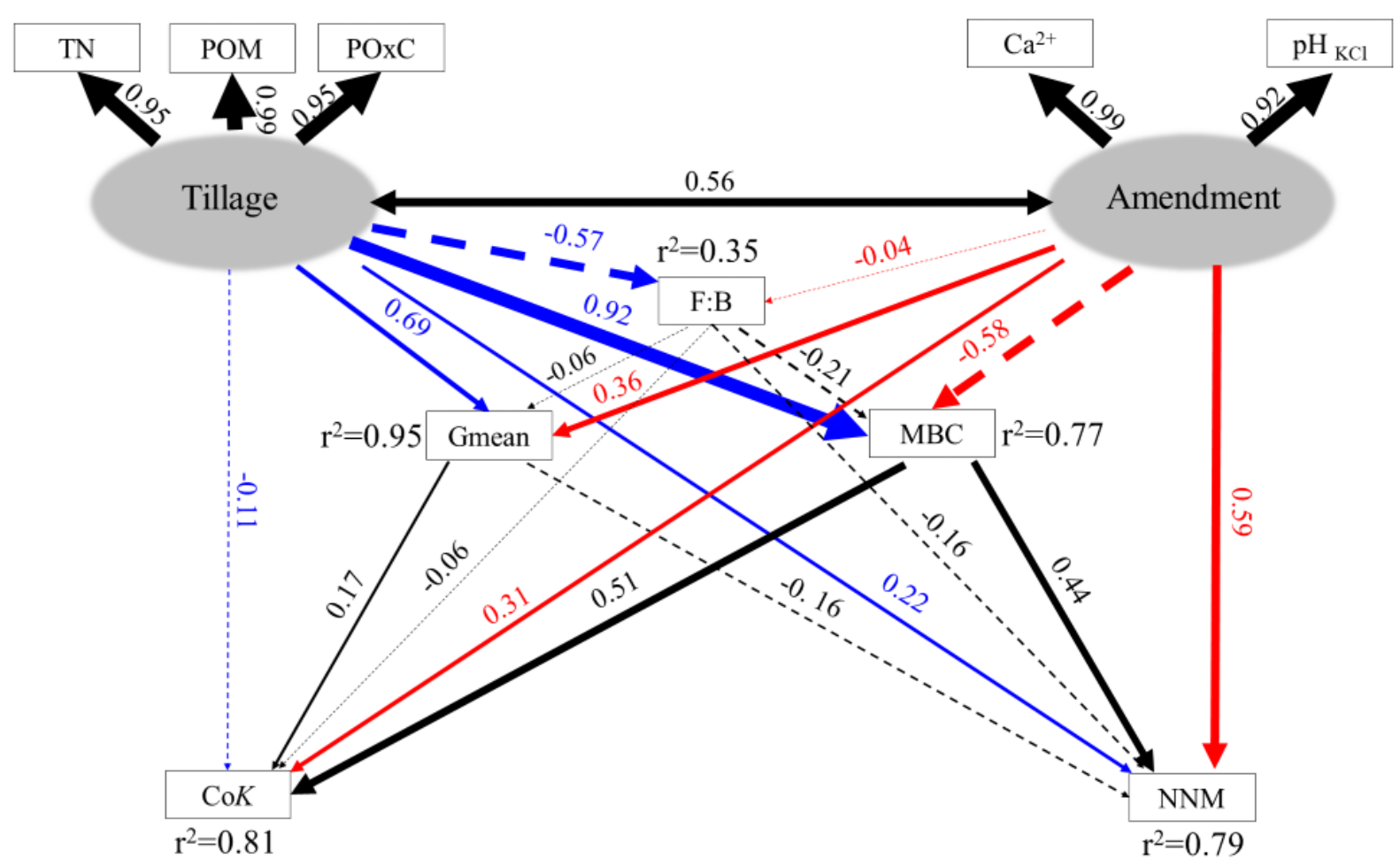

Fig. 4.4.3: The structural equation model (SEM) of the hypothesized relationships between Tillage practices and the Amendment application and soil $\mathrm{C}$ and $\mathrm{N}$ mineralization and net nitrification. The endogenous variables are represented as squares and the latent variables are represented as circle. Blue arrows indicate direct effects of Tillage, red arrows indicate direct effects of Amendment and black arrows indicate indirect effects of both latent variables. Solid lines represent positive path coefficients and dashed arrows indicate negative path coefficients The numbers by the arrows are the standarized path coefficients. The $\mathrm{r}^{2}$ value represents the proportion of total variance explained by the dependent variables. $\mathrm{TN}$, total nitrogen; POM, particulate organic matter; POxC, permanganate oxidizable carbon; Gmean, geometric mean of enzymatic activities; F:B, fungi-to-bacteria ratio; $\mathrm{MBC}$, microbial bioamass carbon; CoK, initial potential $\mathrm{C}$ mineralization rate; $\mathrm{NNM}$, net nitrogen mineralization; $\mathrm{NN}$, net nitrification. 


\subsection{Experiment 5: Effect of NT, liming and depth on soil proteases}

\subsubsection{Soil chemical properties}

The NT plots showed increased SOC, TN, PMN (Table 4.5.1, Fig. 4.5.1), DOC, EN and Carb $_{\mathrm{ex}}$ (Table 4.5.2) contents by $10-23 \%$ on average when compared to TT. Plots subjected to Liming application showed a reduction of MBC, MBN, TOC, EEGRSP (Table 4.5.1, Fig. 4.5.1) and DOC (Table 4.5.2), and an increase in soil pH, EC, EN and PMN (Table 4.5.1, Fig. 4.5.1) and DOC (Table 4.5.2). The majority of the investigated variables decreased with increasing soil depth, with the exception of the C:N ratio (Table 4.5.1, Fig. 4.5.1) and DOC (Table 4.5.2) and the Carb ex $_{\text {content (Table }}$ 4.5.2), which were higher in the deeper soil layers.

Table 4.5.1: Effects Liming (A), tillage (T) and depth (Dpt) on soil enzyme activity and microbial biomass

\begin{tabular}{|c|c|c|c|c|c|c|c|c|c|c|c|c|}
\hline & $\begin{array}{c}\text { Casein } \\
\text { prot. }\end{array}$ & $\begin{array}{l}\text { BAA } \\
\text { prot }\end{array}$ & Gls & $\mathrm{MBC}$ & $\mathrm{MBN}$ & $\mathrm{pH}$ & $\mathrm{EC}$ & TOC & $\mathrm{TN}$ & $\mathrm{C}: \mathrm{N}$ & PMN & $\begin{array}{c}\text { EE- } \\
\text { GRSP }\end{array}$ \\
\hline A & $* * *$ & $* *$ & n.s. & $*$ & $* *$ & $* * *$ & $* *$ & $*$ & n.s. & n.s. & $* * *$ & $*$ \\
\hline $\mathrm{T}$ & n.s. & n.s. & $* * *$ & n.s. & n.s. & n.s. & $*$ & $* *$ & $* *$ & n.s. & $* * *$ & n.s. \\
\hline Dpt & $* * *$ & $*$ & $* * *$ & $* * *$ & $* * *$ & $* * *$ & $* * *$ & $* * *$ & $* * *$ & $* * *$ & $* * *$ & $* * *$ \\
\hline $\mathrm{AxT}$ & n.s. & n.s. & n.s. & n.s. & n.s. & n.s. & n.s. & n.s. & n.s. & n.s. & n.s. & n.s. \\
\hline AxDpt & $* *$ & $*$ & n.s. & n.s. & n.s. & $* * *$ & $* * *$ & n.s. & n.s. & n.s. & $* * *$ & n.s. \\
\hline TxDpt & $*$ & n.s. & $* * *$ & n.s. & $* *$ & n.s. & $* * *$ & $* * *$ & $* * *$ & n.s. & $* * *$ & n.s. \\
\hline $\begin{array}{l}\text { AxTxD } \\
\text { pt }\end{array}$ & n.s. & n.s. & n.s. & n.s. & * & n.s. & n.s. & n.s. & n.s. & n.s. & n.s. & n.s. \\
\hline
\end{tabular}

Casein prot., the activity of casein protease; BBA prot; the activity BAA protease; Gls, the activity of $\beta$ glucosidase; MBC, microbial biomass carbon; MBN, microbial biomass nitrogen; EC, electric conductivity; TC, total carbon; TN, total nitrogen; PMN, potentially mineralizable nitrogen; EE-GRSP, easily-extractable glomalin-related soil protein.

$*$, **, *** $p<0.05,0.01$ and 0.001 respectively; n.s., not significant 
Casein protease ( $\mu$ g tyrosine $\mathrm{g}^{-1}$ soil $2 \mathrm{~h}^{-1}$ )

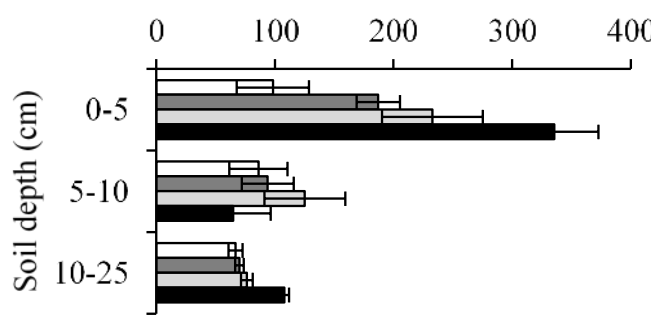

$\beta$-glucosidase $\left(\mu \mathrm{g}\right.$ saligenin $\mathrm{g}^{-1}$ soil $3 \mathrm{~h}^{-1}$ )

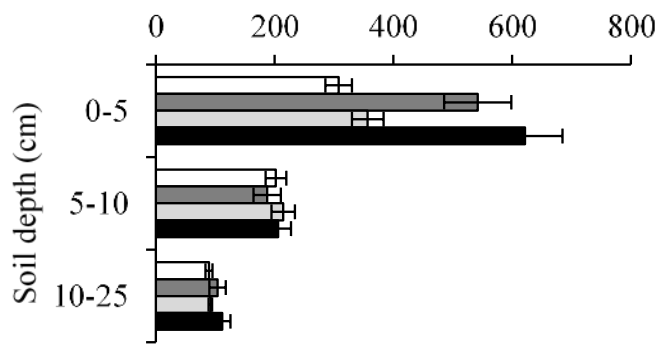

MBN (mg N kg-1 soil)
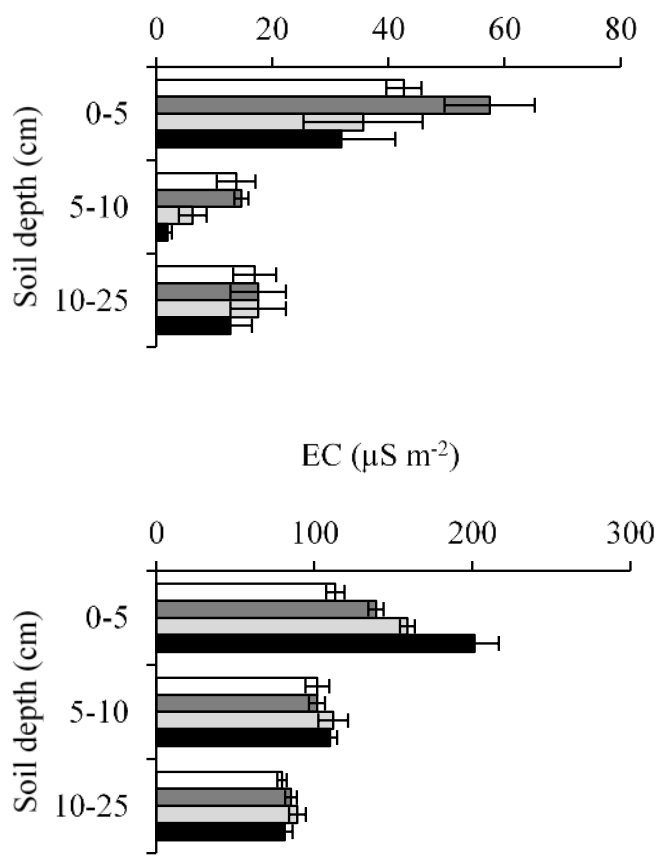

BAA protease (mg NH $\mathrm{NH}_{4}-\mathrm{N} \mathrm{g}^{-1}$ soil $\mathrm{h}^{-1}$ )
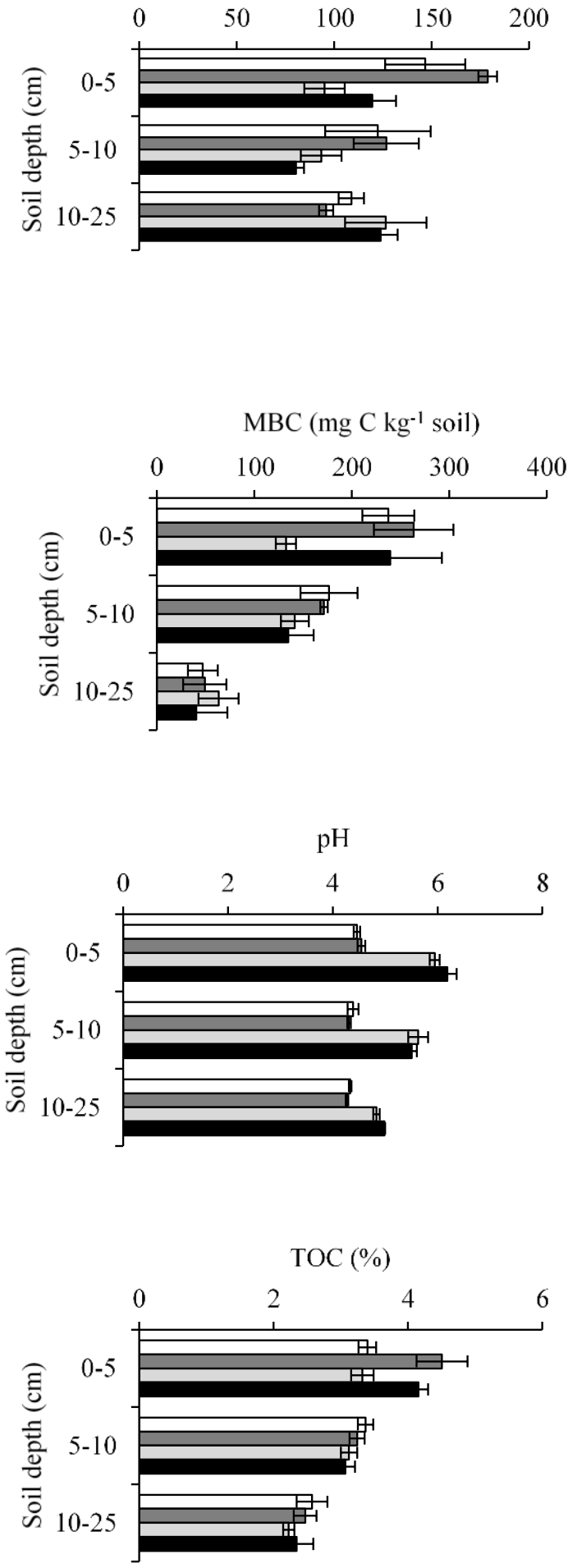

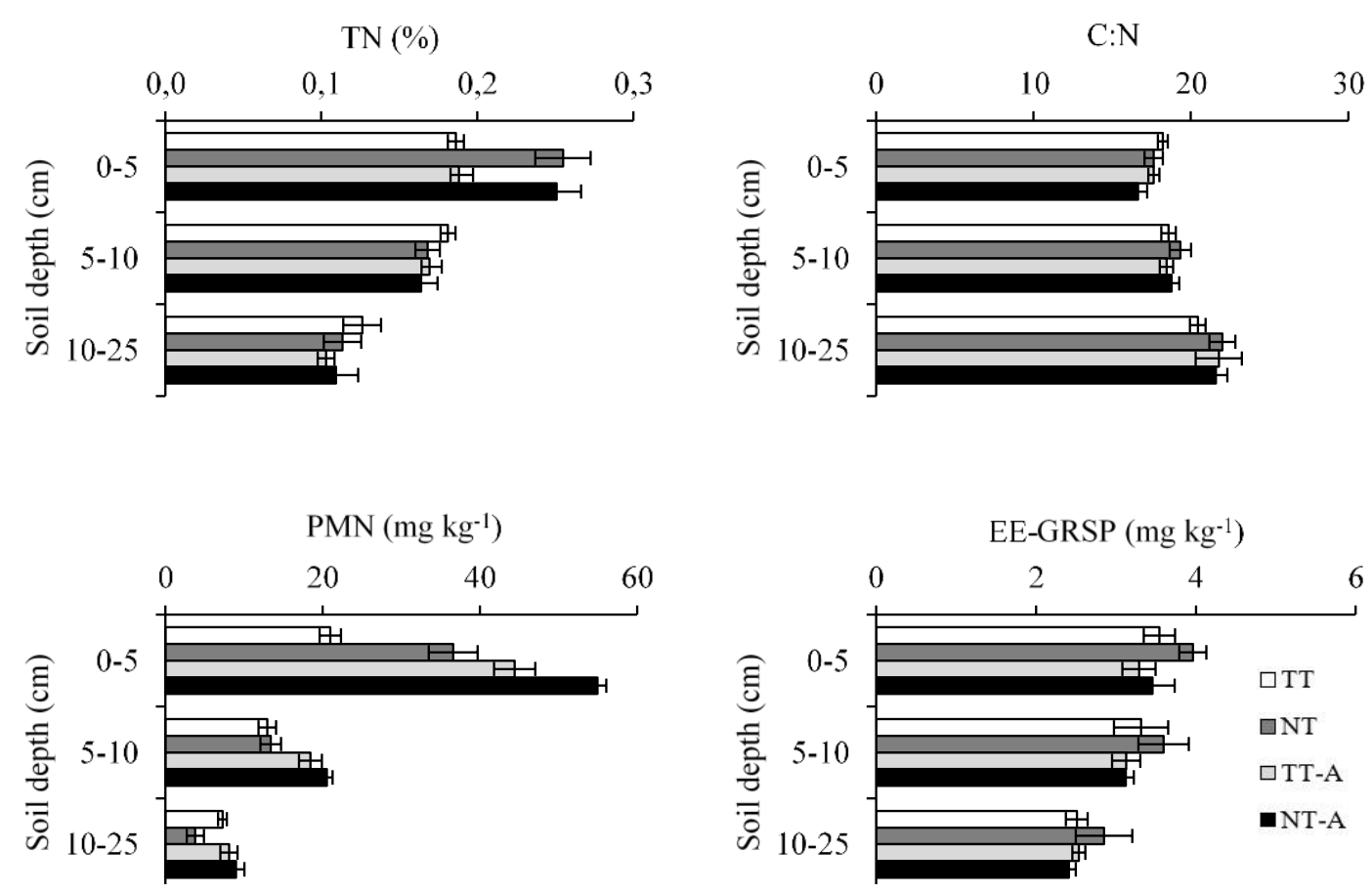

Fig. 4.5.1: The activity of casein protease, BAA protease and $\beta$-glucosidase, microbial biomass carbon (MBC), microbial biomass nitrogen (MBN), soil pH, total organic carbon (TOC), total nitrogen (TN), $\mathrm{C}: \mathrm{N}$ ratio potentially mineralizable nitrogen (PMN) and extractable Bradford-reactive soil protein (EEGRSP) as affected by tillage and Liming in three soil depths. TT, traditional tillage; NT, no-tillage; TT-A, traditional tillage with liming; NT-A, no-tillage with liming amendment. Bars indicate standard errors of the means $(n=4)$.

Table 4.5.2: The content of dissolved organic C (DOC), extractable N (EN), and extractable carbohydrates $\left(\mathrm{Carb}_{\mathrm{ex}}\right)$ as affected by Liming $(\mathrm{A})$, tillage $(\mathrm{T})$ and soil depth $(\mathrm{Dpt})$.

\begin{tabular}{lccc}
\hline & DOC & $\begin{array}{c}\text { EN } \\
\left(\mathrm{mg} \mathrm{kg}^{-1}\right)\end{array}$ & Carb \\
\hline $0-5 \mathrm{~cm}$ & & & \\
TT & 82.14 & 6.09 & 28.18 \\
NT & 101.76 & 10.64 & 37.26 \\
TT-Ca & 81.24 & 10.71 & 20.56 \\
NT-Ca & 98.19 & 21.83 & 23.57 \\
\hline $5-10 \mathrm{~cm}$ & & & \\
TT & 78.29 & 11.69 & 40.40 \\
NT & 74.95 & 17.43 & 45.10 \\
TT-Ca & 53.80 & 12.08 & 31.74 \\
NT-Ca & 55.68 & 20.43 & 46.94 \\
\hline $10-25 \mathrm{~cm}$ & & & \\
TT & 71.27 & 2.56 & 51.85 \\
NT & 74.01 & 2.55 & 60.55 \\
TT-Ca & 61.50 & 4.38 & 52.29 \\
NT-Ca & 70.60 & 7.33 & 53.76 \\
\hline Effects & & & \\
A & $* *$ & $*$ & n.s. \\
T & $*$ & $* *$ & $*$ \\
Dpt & $* * *$ & $* * *$ & $* * *$ \\
AxT & n.s. & n.s. & n.s. \\
AxDpt & n.s. & n.s. & n.s. \\
TxDpt & n.s. & n.s. & n.s. \\
AxTxDpt & n.s. & n.s. & n.s. \\
\hline
\end{tabular}

TT, traditional tillage; NT, no-tillage; TT-A, traditional tillage with liming amendment; NT-A, no-tillage with liming. *, **, *** $p<0.05,0.01$ and 0.001 respectively; n.s., not significant 


\subsubsection{Soil enzymes activities}

The potential activity of Gls was $40 \%$ higher under NT than under TT (Table 4.5.1, Fig. 4.5.1). According to the PCA, the Gls activity was positively correlated with casein protease activity, EC, PMN, pH, and SOC, and negatively correlated with Carbex along the PC1 axis (Table 4.5.3, Fig. 4.5.2). Furthermore, the activity of Gls was positively correlated also with BBA protease activity, MBN, EN, SOC, MBC, TN, EE-GRSP, $\mathrm{NH}_{4}{ }^{+}$and DOC along the PC2 axis (Table 4.5.3, Fig. 4.5.2).

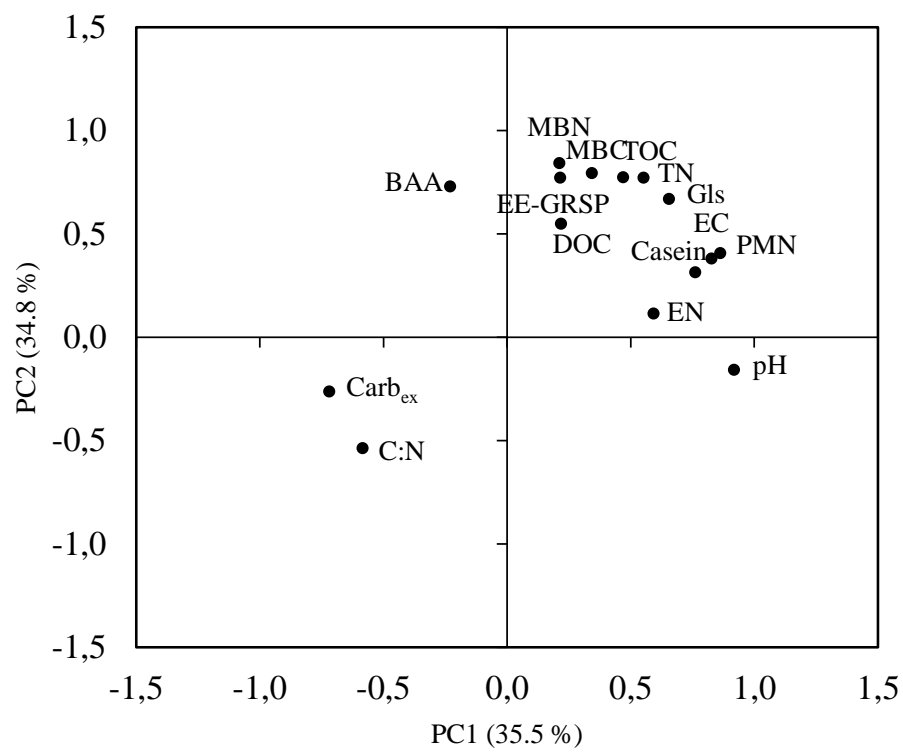

Fig. 4.5.2: Loading plots for measured soil parameters in Principal Components.

Table 4.5.3: Principal component loadings for measured soil parameters

\begin{tabular}{lcc}
\hline \multicolumn{3}{l}{ Rotated component Matrix } \\
\hline Soil parameter & PC1 & PC2 \\
& $35.5 \%$ & $34.8 \%$ \\
\cline { 2 - 3 } pH & $0.919^{\mathrm{a}}$ & \\
PMN & 0.863 & \\
EC & 0.827 & \\
Casein protease & 0.761 & \\
Carb & -0.719 & \\
EN & 0.593 & \\
C:N & -0.585 & -0.537 \\
MBN & & 0.842 \\
MBC & & 0.795 \\
SOC & & 0.775 \\
TN & 0.553 & 0.773 \\
EE-GRSP & & 0.772 \\
BBA & & 0.730 \\
Gls & 0.655 & 0.698 \\
DOC & & 0.547 \\
\hline
\end{tabular}

$\mathrm{PMN}$, potentially mineralizable nitrogen; EC, electric conductivity; Carb ${ }_{\mathrm{ex}}, 0.5 \mathrm{M} \mathrm{K} \mathrm{SO}_{4}$ extractable carbohydrates; $\mathrm{EN}, 0.5 \mathrm{M} \mathrm{K} \mathrm{SO}_{4}$ extractable nitrogen; $\mathrm{MBN}$, microbial biomass nitrogen; $\mathrm{MBC}$, microbial biomass carbon; TC, total carbon; TN, total nitrogen; EE-GRSP, easily extractable glomalinrelated soil protein; DOC, $0.5 \mathrm{M} \mathrm{K}_{2} \mathrm{SO}_{4}$ extractable carbon; ${ }^{\mathrm{a}}$ The scores lower than 0.5 not shown 
Tillage practice did not have any significant impact on the potential activity of soil proteases, but the interaction of tillage with depth showed higher values of casein protease in the $0-5 \mathrm{~cm}$ layer of the NT plots, while this effect was not observable in deeper layers. In limed plots, the activity of casein protease increased by $66 \%$ in and the activity of BAA protease decreased by $34 \%$. According to the PCA, casein protease was loaded with those variables affected by Liming (soil $\mathrm{pH}, \mathrm{PMN}$ and $\mathrm{EN}$ ) while BAA protease was loaded with those affected by tillage practice (SOC, TN, MBC, MBN and EE-GRSP).

\subsubsection{Biomass production}

Plant production was significantly higher in NT plots and was not affected by the Liming application (Fig. 4.5.3). The $\mathrm{C}: \mathrm{N}$ ratio of plant biomass was lower when amendment was applied, especially in TT plots, and negatively correlated with the casein protease:BAA protease ratio.
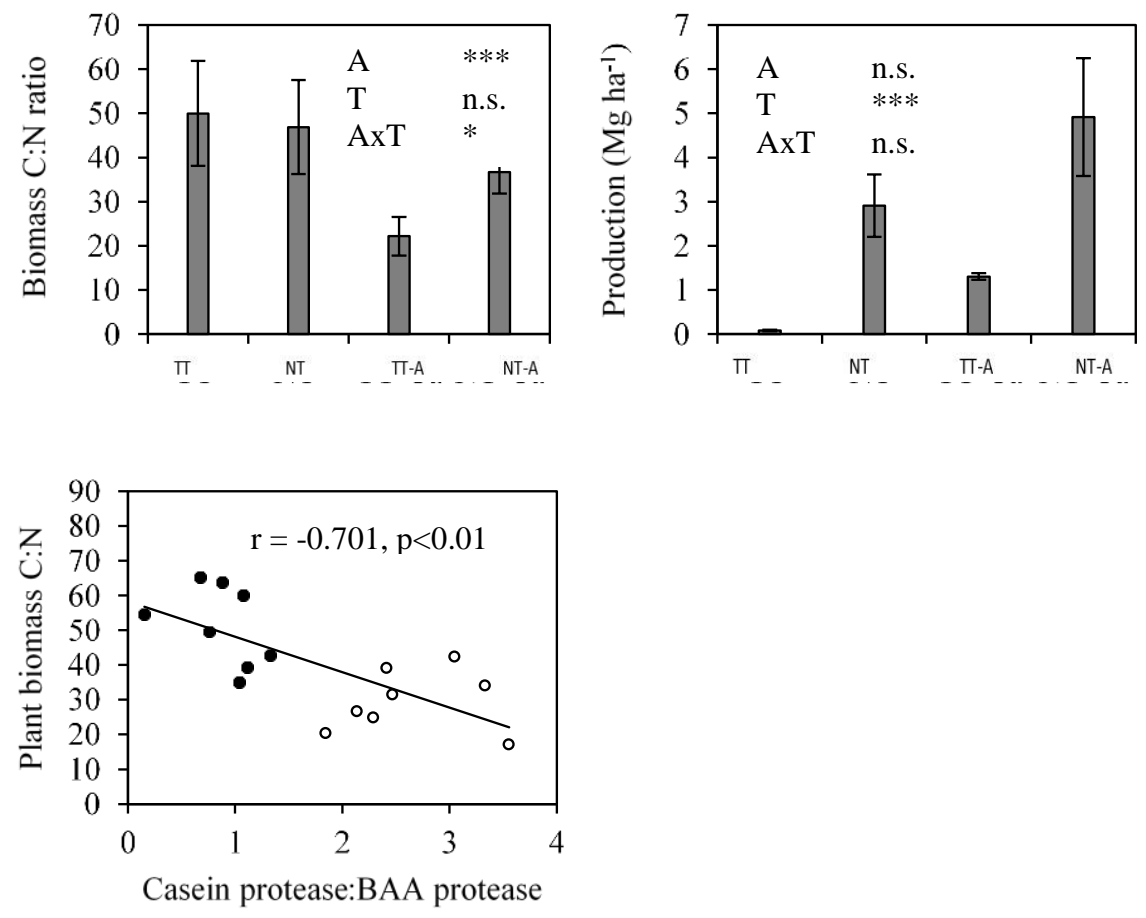

Fig. 4.5.3: The $\mathrm{C}: \mathrm{N}$ ratio of plant aboveground biomass (a), total biomass production (b) and the relationship between biomass $\mathrm{C}: \mathrm{N}$ ratio and the casein protease:BAA protease ratio (c). TT, traditional tillage; NT, no-tillage; TT-A, traditional tillage with liming; NT-A, no-tillage with liming. Bars indicate standard errors of the means $(n=4)$. 


\subsection{Experiment 6: Effect of NT and liming on plant mycorrhization}

\subsubsection{Soil properties}

After 11 years since the establishment of the experiment, the SOC was significantly higher in NT $(\mathrm{p}<0.05)$ while no significant effect of liming was detected. The SOC contents were $28.2 \pm 1.0,30.3 \pm 0.5,27.6 \pm 1.2$ and $31.1 \pm 1.0 \mathrm{~g} \mathrm{~kg}^{-1}$ dry soil in TT-A, NT-A, TT and NT, respectively. In the case of TN, no significant differences were found among treatments. The $\mathrm{TN}$ contents were $1.55 \pm 0.06,1.79 \pm 0.13,1.58 \pm$ 0.06 and $1.71 \pm 0.08 \mathrm{~g} \mathrm{~kg}^{-1}$ dry soil in TT-A, NT-A, TT and NT, respectively.

Table 4.6.1: Soil organic matter fractions and enzymatic activities at the three samplings. Mean \pm standard error of the mean $(n=4)$.

\begin{tabular}{|c|c|c|c|c|c|c|}
\hline & & $\begin{array}{l}\text { POM } \\
\%\end{array}$ & $\begin{array}{l}\text { POxC } \\
\%\end{array}$ & $\begin{array}{l}\text { EN } \\
\mathrm{Mg} \mathrm{kg}^{-1}\end{array}$ & $\begin{array}{l}\text { DHase } \\
\mu \text { moles INTF } \\
\mathrm{g}^{-1} \mathrm{~h}^{-1} 10^{-3}\end{array}$ & $\begin{array}{l}\text { Glm } \\
\mu \text { moles p-nitrophenol } \\
\mathrm{g}^{-1} \mathrm{~h}^{-1}\end{array}$ \\
\hline \multirow{4}{*}{123 DAS } & TT-A & $1.47 \pm 0.06$ & $0.41 \pm 0.04$ & $8.25 \pm 1.4$ & $5.45 \pm 0.81$ & $77.7 \pm 8.2$ \\
\hline & NT-A & $1.68 \pm 0.16$ & $0.53 \pm 0.04$ & $12.1 \pm 2.5$ & $8.23 \pm 3.53$ & $79.1 \pm 14.9$ \\
\hline & TT & $1.49 \pm 0.16$ & $0.38 \pm 0.05$ & $17.1 \pm 3.2$ & $2.23 \pm 0.19$ & $90.5 \pm 10.9$ \\
\hline & NT & $1.69 \pm 0.27$ & $0.38 \pm 0.07$ & $18.5 \pm 3.6$ & $2.07 \pm 0.25$ & $117.0 \pm 13.8$ \\
\hline \multirow[t]{4}{*}{172 DAS } & TT-A & $1.52 \pm 0.07$ & $0.53 \pm 0.06$ & $16.8 \pm 0.7$ & $4.73 \pm 0.47$ & $70.9 \pm 6.4$ \\
\hline & NT-A & $1.98 \pm 0.14$ & $0.77 \pm 0.06$ & $18.4 \pm 1.1$ & $9.18 \pm 2.89$ & $69.1 \pm 2.5$ \\
\hline & TT & $1.33 \pm 0.03$ & $0.44 \pm 0.04$ & $24.1 \pm 1.2$ & $1.47 \pm 0.62$ & $72.7 \pm 6.5$ \\
\hline & NT & $1.45 \pm 0.13$ & $0.60 \pm 0.05$ & $23.6 \pm 2.7$ & $1.86 \pm 0.40$ & $69.6 \pm 2.5$ \\
\hline \multirow[t]{4}{*}{202 DAS } & TT-A & $1.32 \pm 0.12$ & $0.44 \pm 0.03$ & $5.15 \pm 1.0$ & $8.46 \pm 0.72$ & $69.1 \pm 5.6$ \\
\hline & NT-A & $1.64 \pm 0.21$ & $0.49 \pm 0.06$ & $10.2 \pm 2.1$ & $9.66 \pm 2.13$ & $82.9 \pm 8.3$ \\
\hline & TT & $1.21 \pm 0.08$ & $0.31 \pm 0.01$ & $22.0 \pm 1.2$ & $2.11 \pm 0.22$ & $78.2 \pm 0.6$ \\
\hline & NT & $1.37 \pm 0.12$ & $0.35 \pm 0.03$ & $22.1 \pm 1.1$ & $3.08 \pm 0.65$ & $80.3 \pm 3.2$ \\
\hline \multicolumn{7}{|l|}{ Effects } \\
\hline & $\mathrm{T}$ & * & $*$ & n.s. & n.s. & n.s. \\
\hline & A & n.s. & $*$ & $* * *$ & $* *$ & n.s. \\
\hline & Dt & $* *$ & $* * *$ & $* * *$ & $*$ & $* *$ \\
\hline & TxA & n.s. & n.s. & n.s. & n.s. & n.s. \\
\hline & TxDt & n.s. & $* *$ & n.s. & n.s. & n.s. \\
\hline & AxDt & $*$ & n.s. & $* * *$ & n.s. & n.s. \\
\hline & TxAxDt & n.s. & n.s. & n.s. & n.s. & n.s. \\
\hline
\end{tabular}

TT-A traditional tillage with amendment; NT-A no-tillage with amendment; TT traditional tillage; NT no-tillage; POM, particulated organic matter; POxC, permanganate oxidizable carbon; EN, soil extractable nitrogen; DHase, activity of dehydrogenase; Glm, $\beta$-glucosaminidase activity.

$*, * *, * * *$ indicate significant effect at $\mathrm{p}<0.05, \mathrm{p}<0.01$ and $\mathrm{p}<0.001$, respectively; n.s. not significant

The POM and POxC were higher $(\mathrm{p}<0.05)$ in NT than in TT and POxC was also significantly increased by liming (Table 4.6.1). The POM decreased in time showing the lowest value 202 DAS while highest POxC was determined 172 DAS (Table 4.6.1). The EN content was significantly higher in the control treatments (without liming) and the differences between liming and no-liming were the highest 202 DAS (Table 4.6.1). None of the two enzymatic activities was affected by tillage type and only DHase was significantly increased by liming (Table 4.6.1). 
Table 4.6.2: Selected soil chemical properties at the three samplings. Mean \pm standard error of the mean $(\mathrm{n}=4)$.

\begin{tabular}{lccccc}
\hline & $\mathrm{pH}$ & $\mathrm{EC}$ & $\mathrm{P}$ & $\mathrm{Ca}$ & $\mathrm{Mg}$ \\
\cline { 4 - 6 } & & & \multicolumn{4}{c}{$\left(\mathrm{mg} \mathrm{kg}^{-1}\right)$} \\
\hline 123 DAS & & & & & \\
TT-A & $5.93 \pm 0.09$ & $113 \pm 2.3$ & $112 \pm 7$ & $1220 \pm 73$ & $79.3 \pm 3.1$ \\
NT-A & $6.04 \pm 0.20$ & $133 \pm 16$ & $123 \pm 1$ & $1383 \pm 102$ & $81.4 \pm 0.2$ \\
TT & $5.03 \pm 0.03$ & $70.6 \pm 5.7$ & $117 \pm 6$ & $416 \pm 21$ & $61.7 \pm 1.7$ \\
NT & $5.04 \pm 0.10$ & $86.4 \pm 5.1$ & $88 \pm 12$ & $595 \pm 26$ & $72.3 \pm 1.4$ \\
\hline 172 DAS & & & & & \\
TT-A & $5.65 \pm 0.07$ & $232 \pm 6$ & $116 \pm 6$ & $1237 \pm 78$ & $76.8 \pm 5.1$ \\
NT-A & $6.03 \pm 0.26$ & $319 \pm 49$ & $129 \pm 3$ & $1863 \pm 227$ & $92.8 \pm 5.5$ \\
TT & $4.45 \pm 0.02$ & $192 \pm 8$ & $111 \pm 5$ & $378 \pm 45$ & $56.1 \pm 5.2$ \\
NT & $4.59 \pm 0.08$ & $205 \pm 8$ & $109 \pm 8$ & $530 \pm 31$ & $66.4 \pm 6.1$ \\
\hline 202 DAS & & & & & \\
TT-A & $5.80 \pm 0.06$ & $121 \pm 8$ & $115 \pm 4$ & $1184 \pm 80$ & $59.7 \pm 2.1$ \\
NT-A & $6.04 \pm 0.13$ & $143 \pm 13$ & $122 \pm 3$ & $1349 \pm 105$ & $69.5 \pm 2.0$ \\
TT & $4.72 \pm 0.02$ & $77 \pm 3$ & $110 \pm 6$ & $370 \pm 15$ & $56.2 \pm 1.8$ \\
NT & $4.77 \pm 0.09$ & $99 \pm 7$ & $119 \pm 1$ & $462 \pm 49$ & $63.0 \pm 1.6$ \\
\hline T & n.s. & $* *$ & n.s. & $* * *$ & $* * *$ \\
A & $* * *$ & $* * *$ & $*$ & $* * *$ & $* * *$ \\
D & $* *$ & $* * *$ & n.s. & $*$ & $* * *$ \\
TxA & n.s. & n.s. & n.s. & n.s. & n.s. \\
TxDt & n.s. & n.s. & n.s. & n.s. & n.s. \\
AxDt & n.s. & n.s. & n.s. & n.s. & $* *$ \\
TxAxDt & n.s. & n.s. & $*$ & n.s. & n.s. \\
\hline
\end{tabular}

TT-A traditional tillage with amendment; NT-A no-tillage with amendment; TT traditional tillage; NT no-tillage;

$*, * *, * * *$ indicate significant effect at $\mathrm{p}<0.05, \mathrm{p}<0.01$ and $\mathrm{p}<0.001$, respectively; n.s. not significant

Liming amendment increased soil $\mathrm{pH}$ from 4.8 to 5.9 and $\mathrm{EC}$ from 122 to $177 \mu \mathrm{S}$ $\mathrm{cm}^{-1}$ (Table 4.6.2) and both parameters fluctuated during the sampling period. Similarly, liming increased content of $\mathrm{Ca}$ (three times) and $\mathrm{Mg}$ (by 25\%) respect to control plots without liming (Table 4.6.2). In addition, $\mathrm{Ca}$ and $\mathrm{Mg}$ content were significantly lower under TT. The same positive effect of liming was also found in the P content which was 120 and $109 \mathrm{mg} \mathrm{kg}^{-1}$ in the limed and no-limed treatments, respectively (Table 4.6.2).

\subsubsection{Oat plant growth and AMF colonization}

The colonization of oat roots by AMF was stimulated by liming, by NT and increased in time (Fig. 4.6.1, Table 4.6.3). The NT-A treatment showed the highest root colonization (74\% in average for the three samplings) and the highest effect of tillage was found 172 DAS. The NT and liming increased the aboveground biomass of oat plants (Fig. 4.6.1, Table 4.6.3) and their impact changed along the study period: while the effect of tillage practice was evident at least since 123 DAS, the positive effect of liming was only significant since 172 DAS. 
Oat
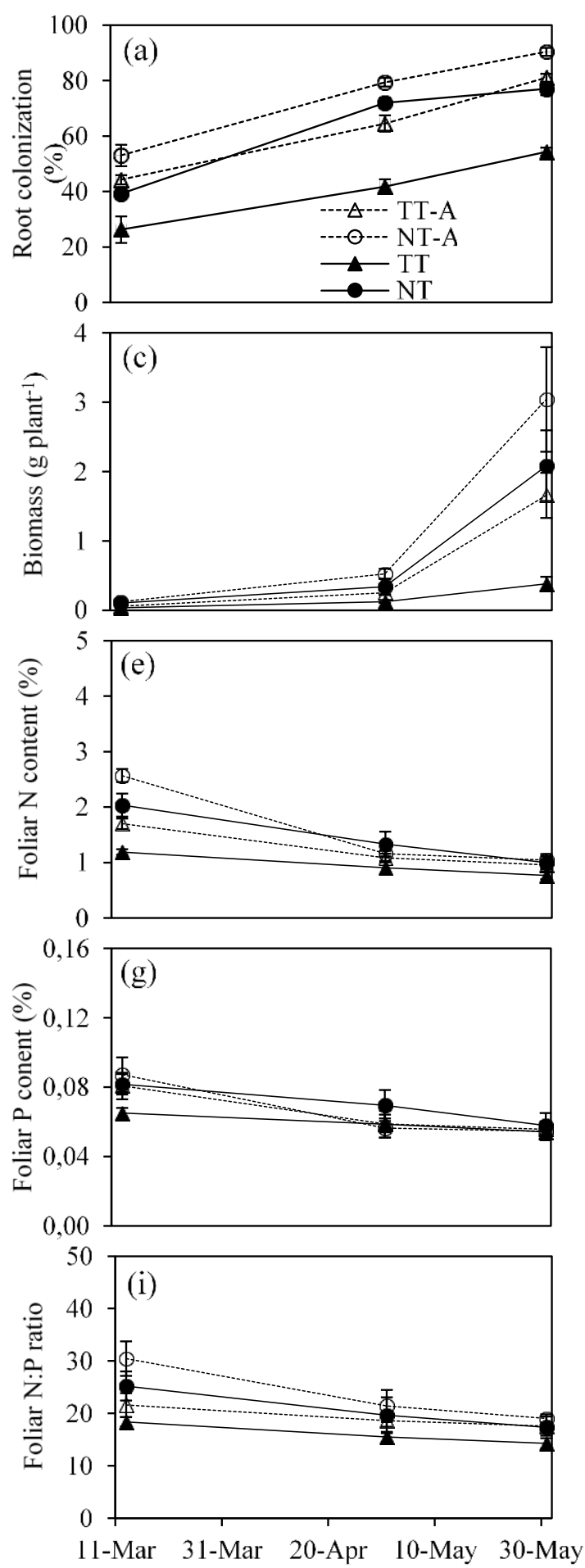

Vetch
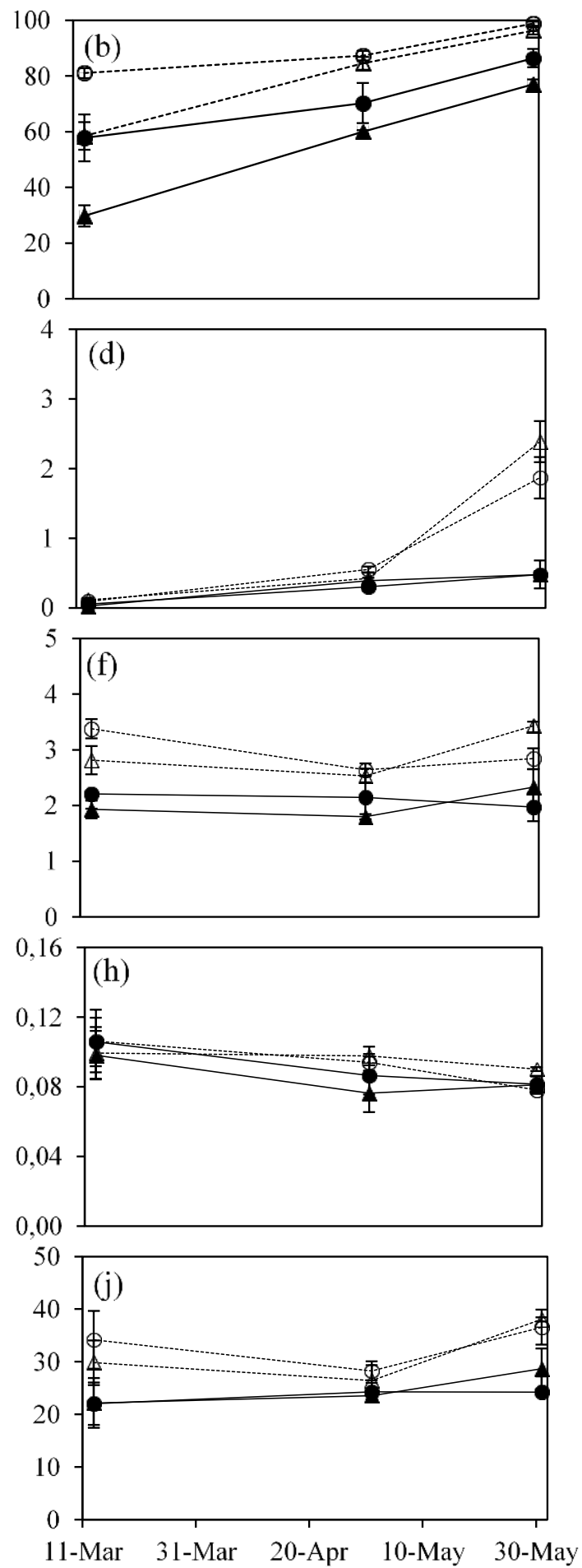

Fig. 4.6.1. Mycorrhizal root colonization (a, b), foliar $N$ content (c, d), foliar $P$ content (e, f) and $N$ :P ratio $(\mathrm{g}, \mathrm{h})$ of oat $(\mathrm{a}, \mathrm{c}, \mathrm{e}, \mathrm{g})$ and vetch plants $(\mathrm{b}, \mathrm{d}, \mathrm{f}, \mathrm{h})$. 
Table 4.6.3: Effects of tillage (T), Liming (A) and date (D) on mycorrhizal root colonization, plant biomass and foliar $\mathrm{N}$ and $\mathrm{P}$ content

\begin{tabular}{|c|c|c|c|c|c|c|c|c|c|c|}
\hline & \multicolumn{5}{|c|}{ Oat } & \multicolumn{5}{|c|}{ Vetch } \\
\hline & Colonization & Biomass & $\mathrm{N}$ & $\mathrm{P}$ & $\mathrm{N}: \mathrm{P}$ & Colonization & Biomass & $\mathrm{N}$ & $\mathrm{P}$ & $\mathrm{N}: \mathrm{P}$ \\
\hline $\mathrm{T}$ & *** & $* *$ & *** & n.s. & $* *$ & *** & n.s. & n.s. & n.s. & n.s. \\
\hline A & $* * *$ & * & $*$ & n.s. & $*$ & $* * *$ & $* * *$ & $* * *$ & n.s. & $* *$ \\
\hline Dt & $* * *$ & $* * *$ & $* * *$ & $* * *$ & $* * *$ & $* * *$ & $* * *$ & n.s. & $*$ & $* *$ \\
\hline TxA & $* * *$ & n.s. & n.s. & n.s. & n.s. & n.s. & n.s. & n.s. & n.s. & n.s. \\
\hline TxDt & $*$ & $* *$ & $* *$ & n.s. & n.s. & $* *$ & n.s. & $*$ & n.s. & n.s. \\
\hline AxDt & n.s. & $*$ & * & n.s. & n.s. & n.s. & $* * *$ & n.s. & n.s. & $*$ \\
\hline TxAxDt & n.s. & n.s. & n.s. & n.s. & n.s. & n.s. & n.s. & n.s. & n.s. & n.s. \\
\hline
\end{tabular}

The highest $\mathrm{N}$ and $\mathrm{P}$ foliar contents were measured for 123 DAS when compared than for the other two samplings (Fig. 4.6.1, Table 4.6.3). The oat $\mathrm{N}$ content was increased by liming and by NT, but the effect of both practices was only significant 123 DAS (Fig. 4.6.1, Table 4.6.3). Oat $\mathrm{P}$ content was not affected by any agronomic practice, while $\mathrm{N}: \mathrm{P}$ ratio of oat aboveground biomass was increased by both $\mathrm{NT}$ and liming (Table 4.6.3).

At the harvest (202 DAS), both NT and liming increased the harvested aboveground biomass of oat (Table 4.6.4). In addition, the higher plant nascence in NT than in TT contributed to the higher oat yield (Table 4.6.4). This higher crop production led to a higher total N and P uptake in NT and limed plots with the highest uptake found in NT-A.

\subsubsection{Vetch plant growth and AMF colonization}

The AMF colonization of vetch roots was higher in liming and NT while increasing in time (Fig. 4.6.1, Table 4.6.3). The average vetch root colonization during the whole study period was $80 \%$ under NT and $68 \%$ in TT, while vetch roots in limed plots were colonized in $84 \%$ and in $64 \%$ in control plots without liming. The interaction TxDt showed that the strongest effect of NT was found 123 DAS when vetch root colonization in NT was 25\% higher than in TT (Fig. 4.6.1, Table 4.6.3). Liming increased the vetch aboveground biomass more than three times respect to unamended plots (Fig. 4.6.1, Table 4.6.3). The highest positive effect of liming was observed 202 DAS at the harvest time No impact of tillage on vetch root colonization was detected. In addition, liming increased the vetch $\mathrm{N}$ content while the interaction between tillage and time revealed that while 123 DAS the N content was higher in NT, at the harvest time the vetch plants from TT plants contained more N. (Fig. 4.6.1, Table 4.6.3). The vetch P content was no affected by any agronomic practices. Therefore, N:P of vetch biomass 
was significantly higher in limed plots and the effect was the highest in the beginning of the spring (123 DAS) and at the harvest (202 DAS).

The total harvested biomass of vetch was increased more than ten times by liming as both plant biomass and vetch nascence were positively affected by liming (Table 4.6.4). In addition, a higher total $\mathrm{N}$ and $\mathrm{P}$ uptake at harvest was observed in the limed plots (Table 4.6.4). Finally, NT and liming increased the total harvested biomass (vetch and oat), and the combination of both practices resulted in the highest crop yield (4918 $\mathrm{kg}$ biomass $\mathrm{ha}^{-1}$ ) (Table 4.6.4).

Table 4.6.4: Effect of tillage (T) and Liming (A) on plant nascence, harvest and $\mathrm{N}$ and $\mathrm{P}$ uptake

\begin{tabular}{|c|c|c|c|c|c|c|c|c|c|}
\hline & \multicolumn{4}{|c|}{ Oat } & \multicolumn{4}{|c|}{ Vetch } & \multirow{3}{*}{$\begin{array}{c}\text { Total } \\
\text { Harvest } \\
\left(\mathrm{kg} \mathrm{ha}^{-1}\right)\end{array}$} \\
\hline & \multirow{2}{*}{$\begin{array}{c}\text { Nascence } \\
(\%)\end{array}$} & Harvest & $\mathrm{N}_{\text {up }}$ & $\mathrm{P}_{\text {up }}$ & \multirow{2}{*}{$\begin{array}{c}\text { Nascence } \\
(\%)\end{array}$} & Harvest & $\mathrm{N}_{\text {up }}$ & $\mathrm{P}_{\text {up }}$ & \\
\hline & & & $\left.\mathrm{kg} \mathrm{ha}^{-1}\right)$ & & & \multicolumn{3}{|c|}{$\left(\mathrm{kg} \mathrm{ha}^{-1}\right)$} & \\
\hline TT-A & 21.53 & 836.70 & 16.34 & 0.92 & 42.00 & 469.42 & 16.04 & 0.42 & 1306.11 \\
\hline NT-A & 57.87 & 4429.29 & 32.95 & 1.68 & 54.06 & 489.25 & 13.45 & 0.38 & 4918.54 \\
\hline TT & 9.63 & 80.14 & 3.06 & 0.21 & 2.31 & 3.88 & 0.10 & 0.00 & 84.01 \\
\hline NT & 57.09 & 2864.16 & 19.20 & 1.11 & 16.99 & 47.90 & 1.15 & 0.04 & 2912.05 \\
\hline \multicolumn{10}{|c|}{ Effects (p-values) } \\
\hline $\mathrm{T}$ & $* * *$ & $* * *$ & $* * *$ & $* * *$ & n.s. & n.s. & n.s. & n.s. & $* * *$ \\
\hline A & n.s. & $* * *$ & $* *$ & $* *$ & $* * *$ & $* * *$ & $* * *$ & $* * *$ & $* * *$ \\
\hline TxA & n.s. & $* *$ & $*$ & $*$ & n.s. & n.s. & n.s. & n.s. & $* * *$ \\
\hline
\end{tabular}

TT-A traditional tillage with amendment; NT-A no-tillage with amendment; TT traditional tillage; NT no-tillage; $\mathrm{N}_{\text {up }}$ nitrogen uptake; $\mathrm{P}_{\text {up }}$ phosphorus uptake

$*, * *, * * *$ indicate significant effect at $\mathrm{p}<0.05, \mathrm{p}<0.01$ and $\mathrm{p}<0.001$, respectively; n.s. not significant 


\section{DISCUSSION}

\subsection{Experiment 1: Seasonal variation of microbial and enzymatic activity}

\subsubsection{Soil properties, soil moisture content and soil temperature}

The study was realized between November 2014 and October 2015 and it involved the complete period between two plowings of TT plots, including one full cultivation cycle (end of October 2014 to the beginning of June 2015). We should emphasize that in October 2014 a refresh dose of SF and RG was applied to amended plots. In the TT plots, the liming amendment was incorporated into the soil by tillage, but in NT plots the amendment remains on the soil surface without any negative effect on plant growth as can be observed in the biomass harvested (data showed in the materials and methods section). Similarly, we did not observe any negative effect on studied biological parameters of SF and RG application on soil surface in NT. This confirmed the feasibility of soil surface lime application in the NT fields as also demonstrated by Caires et al. (2005) and Inagaki et al. (2016). Therefore, the potential of SF in agriculture should be of high interest form the farmer's perspective, as the absence of negative impacts of cheap SF on crop germination and nascence along with augmentation of crop yields can lead to a more sustainable agriculture; as well as from sugar-producer's perspective offering an alternative and economically beneficial use of sugar industry residues. Liming had a clear effect on soil $\mathrm{pH}$ in both 0-5 and 5-10 depth layers although the effect was higher in the top layer, especially in the NT. Beyond the agronomical interest, the lime application has been studied as a strategy to reduce the $\mathrm{N}_{2} \mathrm{O}$ emissions in semiarid climates, where occasional rainfalls in the fallow period between crop seasons are the responsible of a large part of the total emissions (Barton et al. 2013a). The combination of NT and Liming in acid soils which are poorly drained have been reported to decrease greenhouse gases emissions in some cases (GarcíaMarco et al., 2016).

The long term effect of the tillage management techniques in the experimental area can be observed in the greater surface accumulation of SOC and POxC in the NT plots. The surface accumulation of organic C, linked with improved soil physical properties (Gómez-Paccard et al. 2015) could be responsible for the higher GWC of the NT plots during the majority of the months of the study period, characterized by the irregular rainfall distribution with several moths in winter and spring below the 
historical precipitation record. In addition, this improvement in the physical properties has also an impact in the months with excess rainfall, as for example in November, when we found waterlogging conditions in the TT plots already at 5-10 cm depth but not in NT plots during the soil sampling. The higher SOC and the preservation of the biopores under NT increased porosity, water infiltration, water content saturation and saturated hydraulic conductivity which ameliorate the waterlogging conditions in the rainy periods (Gómez-Paccard et al. 2015).

These effects are relevant from the agronomic point of view, because anaerobic conditions in the excess of rainfall lead to decreased seed germination index, while the higher GWC in the months with water deficit can sustain higher plant growth in the months of dryer springs. In both cases, the crop growth and final biomass harvest is increased (Gómez-Paccard et al. 2015). On the background of climate change, where longer and more intense drought with occasional heavy rains in spring and autumn are expected (Varela-Ortega et al., 2016), those relative differences between different landuse management practices can affect the SOC dynamics, $\mathrm{N}$ cycle and microbiological activities. Additionally, the NT showed less extreme temperatures and temperature fluctuation probably because of the larger amount of organic material accumulated on the soil surface and the higher GWC which reduced the thermal conductivity of the soil (Fabrizzi et al. 2005; Dahiya et al. 2007). When combined, the differences in GWC and soil temperature could affect microbial activity during the drought and heat waves and can at least partially alleviate microbial stress caused by extreme conditions and increase soil resistance to disturbances (Hueso et al. 2011; Franco-Andreu et al. 2017).

\subsubsection{The opposite effect of no-tillage and Liming on soil microbial biomass}

The positive effect of the NT on the MBC can be explained by the higher SOC and POxC values in the NT which increase the $\mathrm{C}$ availability for the microbial development (Martín-Lammerding et al., 2015). The higher amount of SOC and POxC in the top soil layer also explains the differences between both depths. The variation among the sampling dates found in the MBC is usual in soils with a marked seasonality (Alvear et al., 2005; Martín-Lammerding et al., 2015; Madejon et al., 2007). However, these authors found a lower MBC in summer than in winter period, which was justified by low soil moisture content and the depletion of the easily available C. In our study, the highest SOC and the second highest POxC were measured in summer because of the large input of $\mathrm{OM}$ in form of stubble after the harvest (the beginning of June), 
especially in NT where a higher amount of organic residues remained on the plots as a result of improved crop growth and crop yield. The later decrease in SOC and POxC in October shows that the depletion of available $\mathrm{C}$ occurred between July and October although it did not affect significantly the MBC. The relatively higher stubble accumulation in the NT plots in July, linked with the significant differences in the GWC and soil temperature in the previous months, might be the responsible of the interaction between tillage management and soil depth which showed the higher differences in the MBC between NT and TT plots in summer period.

The MBN followed similar trends as the MBC in relation with the effect of the T, Dt and Dpt. However, it should be noted that in January the MBN was the lowest from all sampling points, which could be caused by the high GWC of the soils (saturated under TT) similarly to the results found by Alvear et al. (2005) in a chilean Ultisol with waterlogging conditions during the winter.

The decrease of the MBC caused by the liming could be a result of the $\mathrm{pH}$ raise which could lead to shifts in the microbial population. This effect was especially evident in the April, when the PCA showed a negative correlation between the MBC and the soil $\mathrm{pH}$. According to Rousk et al. (2010) the relative abundance of bacteria is correlated with the $\mathrm{pH}$ because of the optimal $\mathrm{pH}$ range for bacterial growth reaches the maximum around $\mathrm{pH}$ 7. The change in the relative abundance of bacteria respect the fungal population can decrease the total MBC because of the lower $\mathrm{C}: \mathrm{N}$ biomass of the bacteria in relation with fungi (Strickland and Rousk 2010). In an incubation experiment carried out with the same soil from an adjacent field, Teutscherova et al. (2017b) found a strong negative correlation between the soil $\mathrm{pH}$ and the $\mathrm{MBC}$ after application of different organic amendments which neutralized soil $\mathrm{pH}$. The positive effect of liming in MBN support our hypothesis of a shift towards an increase in the relative bacteria abundance characterized by lower MBC:MBN ratio. Future exhaustive biological analysis could bring a deeper insight into the changes in microbial community composition.

\subsubsection{Soil basal respiration}

In the Mediterranean area, where the climate seasonality is marked, the soil moisture and temperature are the main important drivers of soil respiration. According to Almagro et al. (2009), in the Mediterranean soils, the temperature affects the soil respiration when the soil moisture is higher than 10-15\%, meanwhile below this level, 
the soil moisture is the main driver of the soil respiration and the temperature has a negative effect. Additionally, excessive soil moisture can affect negatively the soil respiration (Suseela et al., 2012). The BR is defined as the steady rate of respiration in soil originated from the $\mathrm{OM}$ mineralization and it is commonly interpreted as a key indicator for measuring changes in soil quality (Creamer et al. 2014). The lowest BR was measured in January, when the soil temperatures were the lowest and soil moisture were the highest while the highest BR was recorded in the April, during the period with more optimal conditions of soil moisture and temperature. It is remarkable that the peak of Gls was found in the July and not in April as the BR peak. Under dry conditions, the EAs can persist better than the nutrient uptake by the microbial biomass, which can decoupled the microbial respiration and the EAs (Geisseler et al. 2012; Steinweg et al. 2013)

The BR increase caused by NT can be explained by the SOC accumulation, MBC and EAs of the NT plots, especially in the 0-5 cm layer which can be linked with the more auspicious conditions regarding soil GWC and soil temperature in the water deficit months. The PCA of the four sampling dates showed a strong correlation between the SOC, POxC, MBC and the EAs and additionally, a stronger correlation with the GWC3m than the GWC, which shows that there is not an immediate effect of soil moisture in microbial activity (Acosta-Martinez et al., 2014).

The overall slight decrease in BR produced by liming was caused by the differences found in April, where the amended plots showed lower BR than the control plots. Although it is generally accepted that the raise in the soil $\mathrm{pH}$ of acid soils increase the microbial activity and consequently soil respiration (Paradelo et al. 2015), the decrease of $\mathrm{MBC}$ caused by the $\mathrm{pH}$ raise and the possible shift in the microbial population mentioned above might affect the ability of the microbial population to mineralize the OM at least in a short-term (Strickland and Rousk 2010).

\subsubsection{The influence of soil management in enzymatic activities}

Our results confirm previous reports of higher EAs of hydrolases under NT versus TT treatments with greater differences in top layer than in the $5-10 \mathrm{~cm}$ due to higher $\mathrm{C}$ availability (López-Garrido et al., 2014; Martín-Lammerding et al., 2015; Madejon et al., 2007). Indeed, the PCA of the four sampling dates showed a strong correlation among the hydrolases activities and SOC, POxC, BR and MBC. In the NT plots, more SOC is available for the microorganism which lead to a larger MBC and higher BR and 
to the release of larger pools of intracellular and extracellular soil enzymes (AcostaMartínez et al., 2008). This relation can be observed graphically when all the sampling points are plotted in the space defined by PC1 and PC2 (Fig. 4.1.6) since the NT shifted more to the right on the PC1 axis than TT samples.

In the Mediterranean areas, the wide amplitude of soil moisture fluctuation during the year affects soil chemistry and biological activity with significant impact on soil EAs seasonality (Sardans and Peñuelas 2013). The changes in the soil moisture in each season affect more EAs than the SOC status of the soil (Sardans and Peñuelas 2010). The influence of soil moisture in our results was observed in Fig. 4.1.6, where the samples points are distributed along the PC2 (where the GWC had the highest load) with the January and April samples in the upper part of the graph and the July and October samples on the bottom.

At this point, we should highlight the importance of the greater differences between Gls, Glm, ASase and Urease activities under NT and TT management in July, which was similar to MBC and MBN dynamics. The higher GWC and the cooler temperatures of the NT plots during the previous months can explain these differences as it can be seen in the strong correlation in the PCA among those EAs, the MBC and the MBN with the GWC3m in July. This phenomena causes an improvement in the resistance to stress of the soil microorganism (Hueso et al. 2011) and should be elucidated because of its importance in SOM dynamics and nutrients cycling in fields under NT. However, the EAs were measured using laboratory methods with controlled conditions, which are not able to predict the complex effect of drought or hot conditions affecting in situ EAs (Henry 2012). Under drought conditions, the EAs are limited by the lack of diffusion of substrate and enzyme pools, therefore the standard measurement of EAs in slurry, neglecting the diffusion constrains, could not give information about the activity of the enzymatic pool present in the soil in situ conditions. Instead, the laboratory measurements of EAs under controlled conditions can give us information about the changes in the enzymes pool sizes caused by the effect of drought and heat on the microbial populations (Henry 2012). According to our data, in July the NT plots accumulated more of the four enzymes mentioned than the TT and they were reflected in higher potential EAs measured in laboratory. The enzymatic pool present in a soil is a function of the enzymatic production rate and the degradation rate (Geisseler et al. 2012). The less extreme conditions in the NT plots during the spring could lead to 
higher enzyme production than in the TT and the soil drying in the early summer decreased the soil moisture until very low levels more rapidly in TT plots reducing the decomposition rate of the enzymatic pool. Consequently, the enzymatic pools of Gls, Glm, Urease and ASase remained much higher in the NT than in the TT beyond the in situ activity status. Therefore, the NT could be considered as an interesting strategy to enhance the soil enzymes resistance to drought and heat disturbance. Nevertheless, the projected warmer climate along with the higher EAs could influence the $\mathrm{C}$ sequestration potential of the no-tillage systems as found also by Hou et al. (2016) in and in situ soil warming assay.

The urease activity is more sensible to high temperatures if the soil moisture is not extremely low (Sardans et al. 2008) which explains why the highest Urease activity was found in July in the NT treatments. The urease is responsible for the release of inorganic $\mathrm{N}$ from urea, therefore higher urease activity can lead to an accumulation of $\mathrm{NO}_{3}{ }^{-}$in soils during the fallow period between crops and it could cause $\mathrm{N}$ losses by $\mathrm{NO}_{3}{ }^{-}$ leaching in the typical torrential rainfall during the summer or beginning of autumn in the Mediterranean areas (Sardans et al. 2008). In addition, the accumulation of mineral $\mathrm{N}$ during this period when no plants are growing could increase the $\mathrm{N}_{2} \mathrm{O}$ emissions peaks which are often registered after the first rain events after the summer fallow in the semiarid areas (Barton et al. 2011).

The application of liming increased the activity of DHase activity, which is in line with the results from other experiments aiming to test the feasibility of SF as amendment to raise the soil $\mathrm{pH}$ in acid soils (León et al. 2017). They related the increase in the DHase activity with the $\mathrm{pH}$ raise, alleviation of $\mathrm{Al}$ toxicity and overall improvement of soil microbial activity. This explanation can also clarify our results because of the strong correlation showed by the PCA between the $\mathrm{pH}$ and DHase and the previously studied alleviation of the Al toxicity in our experimental plots (GómezPaccard et al. 2013). The higher Gls activity found in the limed plots can be caused by the richness of the SF in cell wall polysaccharides whose decomposition requires glycolytic enzymes (León et al. 2017). Unlike Inagaki et al. (2016), we did not find any effect of Am on ASase activity, although RG is a significant source of sulphur and could affect the production of this enzyme. Furthermore, our results showed an interaction between liming and date, which is reflected in the evolution of the ASase of the limed plots during the study period. The highest ASase of the limed plots was 
reached in the last sampling, which could drive us to the conclusion that the effect of RG on ASase is not immediate. Contrary to the results found by Hoon et al. (2008) or Acosta-Martínez \& Tabatabai (2000) in a study of the effect of liming on acid phosphatase activity, we found an increase in PHase caused by liming. The reason could lay in the stronger correlation found in the four PCA for the separate samplings dates between PHase and $\mathrm{POxC}$ than $\mathrm{PHase}$ and $\mathrm{pH}$, which suggests that the $\mathrm{POxC}$ resemble a more important factor affecting PHase than soil $\mathrm{pH}$ in the studied soil. The higher POxC caused by the liming increased the availability of easily decomposable SOM which consequently increased the activity of PHase (Kandeler et al. 1999).

We expected that the combination of NT and liming could lead to a synergistic interaction which increase the soil microbial activity and thus alter the SOM dynamics and biogeochemical nutrients cycles. With the exception of DHase, we did not find any interaction between the Liming and the tillage neither in the other EAs measured nor in the $\mathrm{BR}, \mathrm{MBC}$ or $\mathrm{MBN}$. 


\subsection{Experiment 2: Gross $N$ transformation rates during summer fallow}

\subsubsection{Adequacy of the experimental design}

We used sieved soil samples instead of intact soil cores for the ${ }^{15} \mathrm{~N}$-pool dilution technique. This decision was motivated by the necessity of achieving a homogeneous distribution of the ${ }^{15} \mathrm{~N}$ label in the soil. The raña areas feature a high content of gravel (Espejo 1987) reaching up to $50 \%$ at our experimental field (Gómez-Paccard et al., 2015) which prevents both the collection of intact soil cores and the homogeneous application of the ${ }^{15} \mathrm{~N}$ solution. To minimize potential bias in gross mineralization estimates caused by the soil sieving (Gütlein et al. 2016), we included a pre-incubation period prior to labelling of $24 \mathrm{~h}$ to stabilize the soil after the sieving as proposed by Dannenmann et al., (2006). In addition, due to the fact that there is a low amount of large stable aggregates $(>2 \mathrm{~mm})$ in our experimental field (Hontoria et al. 2016), the potential influence from the destruction of soil aggregates (relevant for investigating differences between tillage practices) was considered to be negligible.

Another methodological concern of the ${ }^{15} \mathrm{~N}$-pool dilution technique is the adequacy of the amount of ${ }^{15} \mathrm{~N}$ applied and the possible bias in the measurements, since $\mathrm{N}$ substrate will be enhanced compared to natural conditions. In May, the sum of gross nitrification and $\mathrm{NH}_{4}{ }^{+}$immobilization (ammonium consumption) was slightly higher than the gross ammonification but of similar magnitude, while in July the ammonium consumption and production were very similar. Therefore, it is likely that the application of ${ }^{15} \mathrm{~N}$ to the soil stimulated the immobilization rates and those estimates should be considered as potential values, particularly in May when the differences between the gross ammonification and $\mathrm{NH}_{4}{ }^{+}$consumption were higher. Finally, the application of ${ }^{15} \mathrm{~N}$ label solution imposed an increase of $1.82 \%$ and $2.18 \%$ of the GWC in May and July, respectively. This increase of GWC could be critical particularly in July when the initial soil GWC was very low, and could lower the differences between both samplings caused by drought conditions. However, we consider that the lower gross $\mathrm{N}$ transformations found in the dry soil (July) when compared to wetter soil (May) confirmed that the differences between both samplings were not hindered by increased GWC caused by the ${ }^{15} \mathrm{~N}$ label solution.

Finally, samples were purposely taken the upper soil layer $(0-10 \mathrm{~cm})$ only. This decision was based on previous studies in the same site which showed that the main effects of both treatments were strongest in this soil layer along with a significant 
decrease of the soil microbial activity below $5 \mathrm{~cm}$ depth (Vazquez et al. 2017; Hontoria et al. 2018). Moreover, additional analyses revealed that the amount of extractable $\mathrm{N}$ in $\mathrm{K}_{2} \mathrm{SO}_{4}$ of the $10-25 \mathrm{~cm}$ layer was approximately a $30 \%$ of the extractable $\mathrm{N}$ in the $0-10$ $\mathrm{cm}$ layer in the May sampling (not published data). Therefore, the relatively low amount of $\mathrm{N}$ present in deeper layers of the soil profile, and the extremely low precipitation in the period May-July strongly suggests that no leaching or a significant $\mathrm{N}$ redistribution within soil profile occurred between sampling events.

\subsubsection{Effects of environmental conditions}

The collection of the first set of samples coincided with the harvest of the winter forage crop at the end of May. In Mediterranean regions, the crop harvest is usually followed by several months of a fallow period lasting until the beginning of autumn when the next crops are sown. The second sampling was performed in the middle of summer, when drought conditions were at its maximum. In the period between samplings, the bare soil underwent both high soil surface temperatures and a persistent drought due to the strong seasonality of precipitation in the area. The registered rainfall between May and July was scarce and the mean air temperatures heated the upper soil layer to the mean temperature of $31.5^{\circ} \mathrm{C}$ during the study period and to $36.6^{\circ} \mathrm{C}$ during the two weeks before the last sampling. These air and soil temperatures promoted high evaporation rates, which, along with the scarce precipitation, caused a dramatic soil moisture decrease, with a GWC lower than $2 \%$ and a WFPS of $6 \%$ in July. These changes of soil conditions have significant implications for gross $\mathrm{N}$ transformation rates which have been found to be highly dependent on both soil temperature and soil moisture (Hoyle et al. 2006; Luxhøi et al. 2008b; Cheng et al. 2014). Thus, the selection of the sampling dates allowed us to investigate $\mathrm{N}$ transformation processes under two contrasting environmental conditions during the post-harvest fallow: when the soil moisture contents are relatively high and temperatures are mild (right after the crop removal), and when both drought and heat form the most extreme conditions of the Mediterranean summer. Although there were no significant differences between NT and TT in GWC, lower $(\mathrm{p}<0.05)$ WFPS was found under NT, owing to the higher porosity of no-tilled soils (bulk density of $1.43 \mathrm{vs} 1.58 \mathrm{~g} \mathrm{~cm}^{-3}$ in NT and TT, respectively), as described previously in Gómez-Paccard et al. (2015). No-tillage adoption led to a preservation of biopores and to an increase in SOC in the $0-5 \mathrm{~cm}$ layer, both effects playing a significant role in the soil capacity to retain water (Gómez-Paccard et al. 
2015; Hontoria et al. 2018). Such improvement of the soil-water relationships promoted by NT was found to mitigate the $\mathrm{N}_{2} \mathrm{O}$ during season periods when high rainfall events (García-Marco et al. 2016).

Overall, the biological indicators and $\mathrm{N}$ transformation rates decreased between the first and the second sampling, confirming one of our working hypothesis. Our observations can be explained by the decrease of soil moisture and raise of soil temperature (Murphy et al. 2003; Bérard et al. 2011; Hueso et al. 2012; Cheng et al. 2014). Soil microbial activity decreases with drying especially at high temperatures when it becomes limited by the combination of suppressed diffusion of substrates and extracellular enzymes, and the dehydration or death of a substantial proportion of the soil microbial biomass (Borken and Matzner 2009). Accordingly, a decline of MBC, MBN and the abundance of four quantified genes was observed between May and July. In addition, the regression analyses revealed a positive relationship between WFPS and both gross mineralization and gross nitrification rates (Table 5). This marked decrease in the gross $\mathrm{N}$ transformation rates, linked with the absence of plant $\mathrm{N}$ uptake, caused an accumulation of DOC, DON and $\mathrm{NH}_{4}{ }^{+}-\mathrm{N}$ content between the first and the second sampling as found also by Schaeffer et al. (2017) and Parker and Schimel, (2011).

Both DOC and DON play a key role in the $\mathrm{N}$ transformations since the release of labile DON from the more complex molecules plays is considered a bottleneck of $\mathrm{N}$ mineralization and the labile DOC has been found to control the $\mathrm{N}$ immobilization and the nitrification rates (Booth et al. 2005; Cookson et al. 2007; Luxhøi et al. 2008a; Dannenmann et al. 2009). Despite their key effect on $\mathrm{N}$ transformation processes in soil, ammonia oxidizers are considered relatively weak competitors for soil $\mathrm{NH}_{4}{ }^{+}$when compared to soil heterotrophs (Bollmann et al. 2002). Therefore, high DOC availability generally promotes the heterotrophic microbial $\mathrm{NH}_{4}{ }^{+}$immobilization over gross autotrophic nitrification (Gütlein et al. 2017). Furthermore, the large $\mathrm{NH}_{4}{ }^{+}-\mathrm{N}$ pool observed in July reveals a decoupling between ammonification and $\mathrm{NH}_{4}{ }^{+}$consumption, suggesting that nitrification and immobilization are more sensitive to drought and become limited to a higher extent when compared to ammonification. While soil mineralization have been found to occur even under drought conditions (Borken and Matzner 2009; Manzoni et al. 2014; Homyak et al. 2018), low soil moisture content and high temperatures can indeed have an adverse effect on soil nitrifiers and $\mathrm{NH}_{4}{ }^{+}$ diffusion resulting in suppressed soil nitrification rates (Davidson et al. 1990; Luxhøi et 
al. 2008b; Cheng et al. 2014; Schaeffer et al. 2017), as also observed in the present study in the strong reductions of gross nitrification rates and the populations of both AOA and AOB between May and July. In addition, the reduction of $\mathrm{NH}_{4}^{+}$ immobilization between May and July, probably caused by the dramatic decrease in the bacteria abundance, aggravated the $\mathrm{NH}_{4}{ }^{+}-\mathrm{N}$ accumulation. Furthermore, soil organic matter solubilization is mediated by extracellular enzymes which remain active for a longer period of time after the dieback of microbes which released them (Geisseler et al. 2012). The relatively high potential enzymatic activity during summer as observed previously on the same experimental plots by Vazquez et al. (2017), and decreased microbial biomass could result in accumulation of microbial products in form of DOC, DON or $\mathrm{NH}_{4}{ }^{+}-\mathrm{N}$ which can have enormous impact on nutrient transformations at the end of the summer after soil re-wetting and lead to high $\mathrm{N}$ losses (Borken and Matzner 2009; Barton et al. 2011; Evans and Burke 2013; Leitner et al. 2017; Schaeffer et al. 2017)

Mineral $\mathrm{N}$ concentrations in the soil during summer were similar to those observed in Californian annual grasses (Parker and Schimel 2011; Schaeffer et al. 2017) and about half than values reported for a grain-legume rotation in semi-arid Australia (Barton et al., 2011; Barton et al., 2013a). In previous studies there is also a large variation with regard to the form of the mineral $\mathrm{N}$ in the soil (either $\mathrm{NH}_{4}{ }^{+}$or $\mathrm{NO}_{3}{ }^{-}$): Barton et al. (2013a) and Barton et al. (2011) observed that the inorganic $\mathrm{N}$ was accumulated in form of $\mathrm{NO}_{3}{ }^{-} \mathrm{N}$ while in the study of Parker and Schimel (2011) and Schaeffer et al. (2017) the inorganic $\mathrm{N}$ was accumulated mainly in form of $\mathrm{NH}_{4}{ }^{+}-\mathrm{N}$. These differences in the form of accumulated inorganic $\mathrm{N}$ in soil may be caused by the extent and intensity of the drying period, with potentially important consequences for the $\mathrm{N}$ cycling and release of greenhouse gases, because nitrification has been addressed as the main source of $\mathrm{N}_{2} \mathrm{O}$ during the summer fallow if nitrification is not reduced by extreme drought and $\mathrm{NO}_{3}{ }^{-}$tend to accumulate, and subsequent $\mathrm{NO}_{3}{ }^{-}$denitrification may occur after rewetting (Barton et al., 2013a; Barton et al., 2013b; Leitner et al., 2017). Therefore, lower $\mathrm{N}_{2} \mathrm{O}$ emissions could be expected if inorganic $\mathrm{N}$ is accumulated in form of $\mathrm{NH}_{4}{ }^{+}-\mathrm{N}$ and gross nitrification is strongly suppressed as observed in the present study. However, the implications of the differences in the form in which inorganic $\mathrm{N}$ is accumulated in soil and the factors controlling the contrasting results obtained between 
studies need to be better elucidated in order to optimize agronomic practices to reduce potential losses of nutrients.

\subsubsection{Effects of tillage and liming on gross $\mathrm{N}$ mineralization rates}

The adoption of NT practices resulted in an accumulation of SOC and TN in the upper-most soil layer of our site (Gómez-Paccard et al. 2015) as also observed in many other studies (Alvaro-Fuentes et al. 2014; Martín-Lammerding et al. 2015). Additionally, a previous study in the same field plot demonstrated that the microbial activity was higher in the NT plots than in the TT, particularly during the summer period (Vazquez et al. 2017).

The gross $\mathrm{N}$ mineralization rate averaged $1.49 \mathrm{mg} \mathrm{N} \mathrm{kg}^{-1} \mathrm{dws} \mathrm{day}^{-1}$, a value of a similar magnitude of what has been observed at harvest time in other agricultural soils under semi-arid climate (Cookson et al. 2006). In line with our hypothesis, the gross $\mathrm{N}$ mineralization significantly increased by liming, which probably resulted in the relative depletion of the DOC and DON pools in the amended plots. These results are in line with the results found by Corre et al. (2003). Moreover, the raise of the soil $\mathrm{pH}$ has been found to increase the net $\mathrm{N}$ mineralization in a soil collected from the adjacent field within the same study area (Teutscherova et al. 2017a). Our results are further supported by higher DHase activity in the amended plots. DHase is an intracellular enzyme linked with the respiratory processes of soil microbes (Insam 2001) and is usually well correlated with the availability of SOC (Serra-Wittling et al. 1995) as well as with the soil pH (Quilchano and Marañón 2002; Mijangos et al. 2010; León et al. 2017; Vazquez et al. 2017). The positive effect of SF and RG application on $\mathrm{N}$ mineralization and DHase activity is in agreement with the results of León et al. (2017) who found increased activity of DHase and other glycolytic enzymes after the application of the SF. The authors related the enhancement of biological activity to the alleviation of the soil acidity and Al-toxicity, and to the richness of SF in cell wall polysaccharides requiring glycolytic enzymes to decompose the polymeric saccharides while mineralizing organic $\mathrm{N}$ to meet the metabolic nutrient equilibrium (Sinsabaugh et al. 2009). In contrast to amendments, tillage had no significant effect in the DHase despite of the higher SOC in NT. This result is in agreement with Quilchano and Marañon, (2002) who found a strong effect of soil $\mathrm{pH}$ in DHase but no effect of SOC in Mediterranean forest. The authors related such observation to a microbial limitation by insufficient amount of nutrients rather than limitation by SOC in these ecosystems. This 
hypothesis is plausible also in the present study due to relatively high content of SOC in all treatments.

Previous works evaluating the effects of the NT on gross $\mathrm{N}$ mineralization have found inconsistent results, with higher rates (Muruganandam et al. 2010; Laine et al. 2017), lower rates (Dong et al. 2012) or no effect (Cookson et al. 2008; Gómez-Rey et al. 2012). In our case, no overall effect of tillage in gross mineralization was found, contrary to our expectations and despite the higher SOC, TN, DOC, DON and MBC in the NT which is generally related to increase in the gross mineralization rates (Booth et al. 2005; Cookson et al. 2007; Luxhøi et al. 2008a). However, our results revealed a positive effect of NT when combined with liming, which suggests that the low $\mathrm{pH}$ of the non-amended soil may be constraining the gross $\mathrm{N}$ mineralization in the NT plots despite the higher contents of TN, DON and MBC respect to the TT. Other possible explanation of the absence of overall differences in our study could be related to the higher physical protection of the organic matter within soil aggregates in NT plots, as previously suggested by Dong et al. (2012). In a previous study, Hontoria et al. (2016) found improved soil aggregation under no-tillage and accumulation of both $\mathrm{C}$ and $\mathrm{N}$ within water-stable aggregates which support this hypothesis.

Furthermore, the stepwise regression analyses showed that the abundance of soil bacteria was related to the gross $\mathrm{N}$ mineralization while the abundance of soil fungi was discarded from the model. The importance of bacteria in gross $\mathrm{N}$ mineralization and the microbial community shift towards bacteria could be a direct consequence of increased soil pH (Rousk et al. 2010) or could be related to enhanced soil fertility after the application of SF containing large amount of easily degradable organic compounds and available nutrients (León et al. 2017). The changes in the ratio of fungal:bacterial gene copies in response to altered soil properties are well accepted and are often affected by soil fertility and $\mathrm{N}$ availability (Boyle et al. 2008).

\subsubsection{Effects of tillage and liming on $\mathrm{NH} 4+$ consumption}

No differences in gross nitrification rates were found between TT and NT plots but a positive effect of liming application was detected, partially fulfilling our hypothesis. The increase of soil nitrification caused by the amendment is in agreement with other studies where the positive effect of liming on nitrification has been observed under field conditions (Corre et al. 2003) or in incubation experiments using soil from fields adjacent to our plots where the raise of $\mathrm{pH}$ increased soil nitrification 
(Teutscherova et al. 2017a). The regression analysis confirms soil $\mathrm{pH}$ being an important driver of gross nitrification further suggesting that the low $\mathrm{pH}$ value was the main limiting factor in this soil. The positive effect of liming on both AOB and AOA populations was also found previously (Teutscherova et al. 2017a) and could be explained by the reduction of both soil acidity and Al-toxicity.

Correlation between gross ammonification rates and gross nitrification $(\mathrm{R}=0.532$, $\mathrm{p}<0.01)$ suggests that nitrification is dependent on the $\mathrm{NH}_{4}{ }^{+}$flux resulting from ammonification rather than on the actual $\mathrm{NH}_{4}{ }^{+}$content in the soil. The low gross nitrification rates detected in the present study are comparable to the results obtained by Cookson et al. (2006) at harvest in semiarid agricultural Australian soils, but are several times lower than the rates observed by Gómez-Rey et al. (2012) or Cookson et al. (2008) in NT fields during other periods of the year. Although the abundance of both nitrifying groups was discarded from the regression analyses, the gross nitrification rates seemed to be driven more by $\mathrm{AOA}(\mathrm{R}=0.525, \mathrm{p}=0.001)$ rather than by $\mathrm{AOB}$ $(\mathrm{R}=0.358, \mathrm{p}=0.044)$, which is not surprising given the low fertility and extreme environmental conditions of the study area (Prosser and Nicol 2012).

The $\mathrm{NH}_{4}{ }^{+}$immobilization was highly significantly correlated with the bacteria $(\mathrm{R}=0.723, \mathrm{p}<0.001)$ and the stepwise regression confirms bacterial abundance as the main driver of the immobilization of $\mathrm{NH}_{4}{ }^{+}$in soils. The immobilization of $\mathrm{NH}_{4}{ }^{+}$was affected by the tillage practice only in July, resulting in higher immobilization in the TT plots. Similar results were found by Dong et al. (2012) where higher immobilization rates were detected in TT soil when compared to NT treatments, which the authors explained by the effect of the incorporation of the light-fraction organic matter of croporigin and by soil disruption. Similarly, $\mathrm{NO}_{3}{ }^{-}$immobilization was higher in TT in May while no differences were found in July, when the $\mathrm{NO}_{3}{ }^{-}$immobilization rates were very low in all the treatments. This result support the results obtained by Fisk et al., (2015) who found that higher soil organic matter was no able to reduce $\mathrm{N}_{2} \mathrm{O}$ emission via $\mathrm{N}$ immobilization.

The absence of the effect of liming on $\mathrm{N}$ immobilization, linked with the higher gross mineralization and nitrification rates in the limed plots, suggests a decoupling between the two processes increasing the risk of $\mathrm{N}$ losses as also found by Corre et al. (2003). This phenomenon could be further accelerated in the NT-A where the gross mineralization reached the highest rates, while the $\mathrm{N}$ immobilization was lower than in 
TT. Liming application have been found to be able to reduce the $\mathrm{N}_{2} \mathrm{O}$ emissions after soil rewetting (Barton et al., 2013), which highlights the need of detailed evaluation of the possibly higher $\mathrm{N}$ losses risks in NT-A after the first autumn rains. In addition, the $\mathrm{N}$ immobilization rates after the rewetting could elucidate the effect of agronomic practices on soil capacity to retain increased amount of $\mathrm{N}$ for the next crop and prevent leaching losses. Those questions need to be evaluated to enhance our understanding of the $\mathrm{N}$ cycling and the trade-offs of the liming application to restore the acid degraded soils of this region.

In a global change scenario/context with predicted longer and harsher drought periods followed by extreme rainfall events (Varela-Ortega et al. 2016), the Mediterranean rainfed crops require agronomic practices capable to reduce the $\mathrm{N}$ losses caused after the autumn soil rewetting via $\mathrm{N}_{2} \mathrm{O}$ emissions (Barton et al. 2008) or $\mathrm{NO}_{3}{ }^{-}$ leaching (Arregui and Quemada 2006). Our results suggest that liming application increases the $\mathrm{N}$ mineralization which could increase the $\mathrm{N}$ availability for crops during the growing period (Liao et al. 2018) but during the summer fallow could increase the risk of $\mathrm{N}$ losses. Therefore, agronomic practices aiming to extent the plant growth period and root performance, the incorporation of perennials crops, the re-evaluation of the $\mathrm{N}$ fertilizer crop requirements and applications timing (Crews and Peoples 2005) or the transition to crop rotations increasing the $\mathrm{N}$ use efficiency (Sainju et al. 2018) may turn the increased risk of $\mathrm{N}$ losses into a higher $\mathrm{N}$ use efficiency after liming application. 


\subsection{Experiment 3: Post re-wetting soil $\mathrm{N}_{2} \mathrm{O}$ emissions}

\subsubsection{Effects of soil conditioning and agronomic practices on $\mathrm{N}_{2} \mathrm{O}$ emissions}

Soil rewetting triggered the $\mathrm{N}_{2} \mathrm{O}$ emissions of a Mediterranean soil, which is in line with the stimulation of $\mathrm{N}_{2} \mathrm{O}$ emissions conducted in field (Barton et al. 2011, 2013b; Leitner et al. 2017) or in laboratory experiments (Barton et al. 2013a). In addition, this stimulation of the $\mathrm{N}_{2} \mathrm{O}$ fluxes remained elevated over the first 24-48 hours after rewetting as in previous studies (Barton et al., 2013; Guo et al., 2014; Leitner et al., 2017). Our cumulative $\mathrm{N}_{2} \mathrm{O}$ emissions were of the same magnitude as those observed from soils proceeding from cooler and humid climates (Harrison-Kirk et al. 2013; Guo et al. 2014).

Despite of the differences in soil moisture upon rewetting, both treatments followed a similar pattern of $\mathrm{N}_{2} \mathrm{O}$ emissions with the highest fluxes during the first $24 \mathrm{~h}$ after rewetting. Although the importance of soil moisture in $\mathrm{N}_{2} \mathrm{O}$ emissions has been extensively demonstrated (Butterbach-Bahl et al. 2013; Martins et al. 2015) we observed strong effect of rewetting event on $\mathrm{N}_{2} \mathrm{O}$ fluxes with minor differences between soil moisture levels. When the soil samples rewetted to $100 \%$ FC reached the soil moisture equivalent to $50 \% \mathrm{FC}$ (after approximately $360 \mathrm{~h}$ of incubation), the $\mathrm{N}_{2} \mathrm{O}$ fluxes were several times lower than the fluxes observed at 50\% FC samples immediately after rewetting. Upon soil rewetting, the key driver of $\mathrm{N}_{2} \mathrm{O}$ fluxes seems to be the amount of N-bearing compounds which accumulated during the drought period, and their subsequent mineralization, nitrification and denitrification rates when the soil moisture increases (Leitner et al. 2017). The initial $\mathrm{N}$ mineral content of the soil used for this experiment was lower than the $\mathrm{N}$ mineral content found on the same field plots during the summer fallow (Vazquez et al., 2019). Therefore, the $\mathrm{N}_{2} \mathrm{O}$ emissions could be potentially higher if the rewetting event takes place in periods when the accumulation of mineral $\mathrm{N}$ is higher than in the used soil. These findings confirm the potential of water irrigation optimization and planification as an efficient strategy to mitigate the $\mathrm{N}_{2} \mathrm{O}$ emissions in Mediterranean soils (Sanz-Cobena et al. 2017). The use of continuous drip irrigation with lower amounts of water may be a suitable alternative to irrigation events as to avoid soil drying and wetting cycles that may lead to a reduction of $\mathrm{N}_{2} \mathrm{O}$ emissions from Mediterranean agro-ecosystems (Deng et al. 2018).

The cumulative $\mathrm{N}_{2} \mathrm{O}$ emissions were significantly higher in the $100 \% \mathrm{FC}$ than in $50 \%$ FC, which was caused by higher gas fluxes in the late stages of incubation when 
the soil moisture of $50 \%$ FC treatment was already below the $20 \%$ of FC. This result is in agreement with Guo et al. (2014) who found higher $\mathrm{N}_{2} \mathrm{O}$ emissions in the more intense rewetting process. Higher soil moisture levels could stimulate the denitrification of accumulated $\mathrm{NO}_{3}{ }^{-}$and higher $\mathrm{N}$ mineralization rates (Miller et al. 2005; Guo et al. 2014). However, the $\mathrm{N}_{2} \mathrm{O}$ emissions were higher at 50\% FC than $100 \% \mathrm{FC}$ during the first two hours after rewetting when the higher fluxes were registered. This result was unexpected because at higher soil moisture upon rewetting, higher denitrification of the soil $\mathrm{NO}_{3}{ }^{-}$should be expected (Ruser et al. 2006). This low $\mathrm{N}_{2} \mathrm{O}$ emission at $100 \% \mathrm{FC}$ was observed as the lowest emissions of the amended treatments.

The cumulative $\mathrm{N}_{2} \mathrm{O}$ emissions of the limed treatments were more than $60 \%$ lower than the amount of $\mathrm{N}_{2} \mathrm{O}$ emitted from non-amended treatments, which confirms liming as a promising strategy to mitigate the $\mathrm{N}_{2} \mathrm{O}$ emission of the acid Mediterranean soil during early autumn rains (Barton et al. 2013b, a). This could also apply for the irrigated agricultural lands in the Mediterranean regions where $\mathrm{N}_{2} \mathrm{O}$ pulses are often observed after irrigation events (Aguilera et al. 2013; Deng et al. 2018). This usefulness of liming for $\mathrm{N}_{2} \mathrm{O}$ emission reduction could seem contradicting with the often observed higher $\mathrm{N}$ mineralization and nitrification rates in the limed soils (Haynes and Swift 1988; Feng et al. 2003; Teutscherova et al. 2017a). Higher $N$ mineralization during the cropping season stimulates the plant $\mathrm{N}$ uptake (Liao et al. 2018) but during fallow periods could induce an accumulation of inorganic $\mathrm{N}$ in soils and increase the risk of $\mathrm{N}$ losses (Leitner et al., 2017; Vazquez et al., 2019). While possible reduction of $\mathrm{N}_{2} \mathrm{O}$ fluxes upon rewetting confirms the feasibility of liming as GHG mitigation strategy, the $\mathrm{CO}_{2}$ emission derived from the $\mathrm{CaCO}_{3}$ dissolution in soil must be considered to confirm the economic and environmental feasibility of liming as GHG mitigation strategy (Barton et al. 2014).

While the impact of liming on GHG emissions is likely determined by the alteration of soil $\mathrm{pH}$, the impact of $\mathrm{NT}$ on $\mathrm{N}_{2} \mathrm{O}$ emissions is unclear and it seems to be related with environmental factor, the specific agronomic management and the time since the conversion to NT (Six et al., 2004; van Kessel et al., 2013). Thus, the importance of NT in climate change mitigation strategies lies in the SOC sequestration potential (Sanz-Cobeña et al., 2017; Six et al., 2004). Previous results of the present field trial showed a reduction of $\mathrm{N}_{2} \mathrm{O}$ emissions in NT plots which was likely related with the improvement of soil physical properties and water drainage (García-Marco et 
al., 2016). Instead, in our rewetting study using disturbed soil, we expected higher $\mathrm{N}_{2} \mathrm{O}$ emissions because of the higher SOC and TN in NT which increased N mineralization and the amount of $\mathrm{NH}_{4}{ }^{+}$as a substrate for nitrification as previously observed by (Vazquez et al. 2019). In addition, the higher SOC in NT could increase the soil respiration upon rewetting and generate temporally anaerobic microsites where denitrification can occur (Barton et al. 2013a; Leitner et al. 2017). However, no significant effect of tillage practices on $\mathrm{N}_{2} \mathrm{O}$ was detected, which could be related with the higher $\mathrm{C}$ substrate availability in NT stimulating the microbial growth and N sequestration in biomass or further reduction of $\mathrm{N}_{2} \mathrm{O}$ to $\mathrm{N}_{2}$ (Liang et al., 2016). The obtained results may have been altered by the soil preparation prior the incubation experiment in which GHG are evaluated (Lagomarsino et al. 2016). The soil sieving is known to stimulate the $\mathrm{N}_{2} \mathrm{O}$ fluxes because of the aggregate disruption enhance the availability of organic $\mathrm{N}$ compounds which are prone to mineralization (Kristensen et al. 2010; Lagomarsino et al. 2016). In addition, the use of sieved soil instead of undisturbed soil cores could reduce the effect of different soil structure in tilled and notilled soils (Gómez-Paccard et al. 2015; García-Marco et al. 2016). Despite of these considerations, we decided to use sieved soil as the high abundance of rock fragments ( $>50 \%$ in weight) would hinder homogeneous soil rewetting. Because of this, the obtained $\mathrm{N}_{2} \mathrm{O}$ fluxes may have been overestimated especially in NT treatments where the SOC and TN content were higher than in TT. In any case, the purpose of the present study was to evaluate the mechanism related to $\mathrm{N}_{2} \mathrm{O}$ after soil rewetting, rather than the assessment of the contribution of this event to annual $\mathrm{N}_{2} \mathrm{O}$ emissions of the agricultural system. For this purpose, continuous on field GHG emissions should be carried out.

\subsubsection{Microbial communities and their effect on $\mathrm{N}_{2} \mathrm{O}$ emissions}

Our results confirm the strong impact of liming on the microbial communities involved in $\mathrm{N}$ cycling, affecting the size, structure and transcription of determined genebearing populations. Liming strongly increased the AOB-amoA community size while the AOA-amoA community size was unaffected. This is in line with previous studies showing relative increase of $\mathrm{AOB}$ respect to AOA community after liming (Banning et al. 2015; Teutscherova et al. 2017a). This shift from AOA towards AOB have been related with the reduction of the $\mathrm{N}_{2} \mathrm{O}$ emission after soil rewetting (Barton et al. 2013a). However, a recent study have found that AOB yield higher $\mathrm{N}_{2} \mathrm{O}$ than AOA during nitrification (Hink et al. 2017). Therefore, the role of liming in $\mathrm{N}_{2} \mathrm{O}$ emissions 
mitigation seems to be more related with the stimulation of $\mathrm{NO}_{2}{ }^{-}$oxidation to $\mathrm{NO}_{3}{ }^{-}$ which reduces the $\mathrm{NO}_{2}{ }^{-}$accumulation in soil (Feng et al. 2003).

The strong effect of soil $\mathrm{pH}$ on denitrification process have been studied during the last decades and higher denitrification activities and lower $\mathrm{N}_{2} \mathrm{O} /\left(\mathrm{N}_{2} \mathrm{O}+\mathrm{N}_{2}\right)$ ratios have been detected at higher soil pH (Šimek and Cooper 2002; Liu et al. 2010). In the present study, liming increased the size of the nirK-bearing and nosZ-bearing communities but not that of nirS-bearing community. This finding confirms previous studies which have found a strong effect of soil $\mathrm{pH}$ on the size of denitrifier communities (Bárta et al. 2010; Čuhel et al. 2010; Liu et al. 2010, 2014). In addition, liming changed the nirK and nirS-bearing community structures and enhanced the diversity of nirS-bearing communities, which revealed the capacity of denitrifiers to adapt to a new soil pH (Šimek and Cooper 2002). In addition, low soil pH has been found to strongly reduce the denitrifier-genes transcription (Liu et al. 2010, 2014; Brenzinger et al. 2015). In the present study, the nirK-gene transcription was higher in the limed soil than in the no-amended treatments at both soil moistures and sampling times.

The evaluation of the expression of genes involved in $\mathrm{N}$-cycling has been recently proposed as an useful tool for disentangling of the processes involved in the soil $\mathrm{N}_{2} \mathrm{O}$ emissions peaks (Németh et al. 2014; Theodorakopoulos et al. 2017). During our incubation, transcriptional activity was detected only in the nirK gene with higher transcriptional level in the limed soils. The transcription of amoA, nirS and nos $Z$ genes was bellow or near the detection limit. The absence of expression of the above mentioned functional genes after soil rewetting could be related to the absence of suitable substrates or energy sources to promote the microbial growth (Liu et al. 2010). Although the size of nirS-bearing community was comparable with nirK-bearing community, the expression of the nirS gene was below the detection limit. Previous studies have also found differences in the transcription levels of nirK and nirS genes in soil bacterial communities despite the initial population size (Sharma et al. 2005; Liu et al. 2010), which highlights the sensitivity of the different community to different environmental/experimental conditions.

The absence of transcription of the nitrifiers and the high transcription of nirK gene during the $\mathrm{N}_{2} \mathrm{O}$ peak upon rewetting may suggested that the $\mathrm{N}_{2} \mathrm{O}$ was rather denitrification-derived. Assuming this hypothesis and considering the higher nirK 
transcription level in limed soil, we could hypothesize that the liming mitigation of the $\mathrm{N}_{2} \mathrm{O}$ emissions was caused by a higher denitrification activity which stimulated the complete denitrification to $\mathrm{N}_{2}$. This hypothesis is in accordance with the results obtained by McMillan et al. (2016), and might be supported by the higher effect of liming in the emission peak after $2 \mathrm{~h}$ at $100 \%$ FC. At high level of moisture, the denitrification is expected to be higher than at low soil moisture and therefore, the effect of liming suppressing the $\mathrm{N}_{2} \mathrm{O}$ emissions could have been more evident. This assumption may be partiality confirmed by the results obtained by Barton et al. (2013a) where denitrification was proposed as the main source of $\mathrm{N}_{2} \mathrm{O}$ emission after the first soil rewetting. However, the authors did not find a mitigation effect of liming in this denitrification $\mathrm{N}_{2} \mathrm{O}$ peak.

However, the absence of detectable nos $Z$ gene transcription does not confirm the speculation of complete denitrification to $\mathrm{N}_{2}$ as $n o s Z$ gene is responsible for the final step of denitrification. A similar contradiction was found by Liu et al. (2010) where the nos $Z$ gene transcription did not follow the same transcription stimulation at high soil $\mathrm{pH}$ as for nirK and nirS genes. In a subsequent study, the same authors found that the mechanism by which soil $\mathrm{pH}$ controls the $\mathrm{N}_{2} \mathrm{O}$ reduction was a posttranscriptional interference in the expression of nos $\mathrm{Z}$ gene. At low $\mathrm{pH}$, soils are not able to reduce $\mathrm{N}_{2} \mathrm{O}$ to $\mathrm{N}_{2}$ by mean of $\mathrm{N}_{2} \mathrm{OR}$ despite of their transcriptional rates because of the incapacity to assemble functional $\mathrm{N}_{2} \mathrm{O}$ reductase enzyme ( $\mathrm{Liu}$ et al. 2014; Obia et al. 2015). Therefore, although no de novo nos $\mathrm{Z}$ synthesis was detected, the $\mathrm{N}_{2} \mathrm{OR}$ already present in the no-amended soil could be inactive because of the low soil pH. However, the quantification of $\mathrm{N}_{2}$ emissions and the application of a labile $\mathrm{C}$ source to stimulate the transcription (Liu et al. 2010) would be necessary to confirm such hypothesis.

Furthermore, the transcriptional activity and its importance in $\mathrm{N}$ transformations should be treated with caution, as the absence of detectable de novo nitrifier synthesis, does not necessarily mean the complete absence of nitrification using an existing proteome. The use of ${ }^{15} \mathrm{~N}$ techniques along with the mRNA evaluation could elucidate the importance of the nitrification upon rewetting.

The effect of tillage practices over the microbial communities was lower than the liming effect, and only changes in the nosZ-bearing community size and AOB-amoA community structure and diversity were observed. The nosZ-bearing community size was lower in NT than in TT, which could be related with the lower periods of 
waterlogging and anoxic condition in NT during winter (Gómez-Paccard et al. 2015; García-Marco et al. 2016). The increase of AOB-amoA diversity index could be related with the higher TN content and higher susceptibility of this bacterial group to tillage disturbance as proposed by Segal et al. (2017). In addition, previous studies have demonstrated the amelioration of drought and extreme soil temperatures in NT when compared to TT (Vazquez et al. 2017) which could promote a development of more diverse AOB community. Unlike expected, tillage did not affect the transcription of the studied functional genes. Previous studies have demonstrated that the transcription of denitrifiers could be suppressed by the absence of labile C substrates (Liu et al. 2010; Németh et al. 2014; Obia et al. 2016). Therefore, higher transcription levels could be expected in NT soil where a higher C labile pool had been previously observed (Vazquez et al. 2017). This could be more pronounced in nos $Z$ gene expression which is more sensible to the lack of $C$ substrate (Henderson et al. 2010; Németh et al. 2014). Future studies should focus on the in situ evaluation of the effect of no-tillage on the microbial gene expression and its relation with greenhouse gases emissions. 


\subsection{Experiment 4: Effects of NT and liming on carbon and nitrogen mineralization}

\subsubsection{Effect of tillage practice}

Several studies have reported a lower impact of NT in deeper layers, reducing the effectiveness to store C and N to the first soil layers (Gál et al. 2007; Alvaro-Fuentes et al. 2014), which was also confirmed by our results. As the aim of the present study was the evaluation of the mechanisms driving $\mathrm{C}$ and $\mathrm{N}$ transformation under two common agricultural practices, we therefore focused on the topsoil layer, where the impact of both practices was the strongest. However, to assess the whole impact of NT on C and $\mathrm{N}$ storage, deeper soil layers should be analyzed.

The accumulation of $\mathrm{C}$ in the upper layer of the NT plots can be related to: (i) the higher $\mathrm{C}$ inputs derived from higher crop biomass produced in the NT plots (Hontoria et al. 2018), (ii) the no-incorporation of stubble into the soil which reduces the accessibility of soil microbial decomposer to biomass inputs (Chatterjee and Lal 2009) and to (iii) the reduction of the tillage-induced soil disturbance and consequent disruption of soil aggregates, which may reduce the accessibility of soil $\mathrm{C}$ to soil microorganisms (Six et al. 1999). Such a reduction of plant residues decomposition is also supported by the higher content of POM, which represents a partially decomposed SOM in the NT soils respect to the TT plots, as pointed out by Plaza-Bonilla et al. (2014).

The POxC, representing the labile $\mathrm{C}$ fractions, is a sensitive indicator of changes induced by soil management (Hurisso et al. 2016). In the present study, POxC was higher in the NT plots than in the TT, although with difference of lower magnitude than the difference found in POM, which is in accordance with Plaza-Bonilla et al. (2014). Altogether, both POxC and POM resulted to be suitable predictors of the soil $\mathrm{C}$ as reflected in the high correlation (Table 3.2.9).

Several studies have found higher MBC contents and enzymatic activities under NT in Mediterranean areas as a result of higher SOM content and higher moisture content during drought (Madejón et al. 2009; Vazquez et al. 2017). In general, NT increases the relative importance of fungi respect to bacteria $(\mathrm{F}: \mathrm{B})$ due to the disruption of fragile fungal hyphae by tillage (Zhang et al. 2012). Our results, similarly to those of 
Helgason et al. (2009), confirm higher fungi and higher bacteria population under NT but no significant difference in $\mathrm{F}: \mathrm{B}$ ratio.

The mineralization of soil $\mathrm{C}$ during the incubation period was higher under NT than in TT although the differences were detectable only in the top soil layer. These results can be linked to the increase of all evaluated $\mathrm{C}$ pools (the substrate for the $\mathrm{C}$ mineralization), microbial abundance (the microorganism responsible for the mineralization) and activity measured as enzymatic activities which catalyze the decomposition process. Similarly, NNM was higher in NT than in TT as found also by Halpern et al. (2010) and can be justified in a similar way as the increase of C mineralization. The correlation analyses (Table 3.2.9) confirmed the importance of SOM fractions as predictor of the soil $\mathrm{N}$ mineralization (Schomberg et al. 2009). Finally, NN was also increased by NT and seemed to be determined by the flow of $\mathrm{NH}_{4}{ }^{+}$released from SOM mineralization. Therefore, our results confirmed our first hypothesis of higher $\mathrm{C}$ and $\mathrm{N}$ pools, microbial biomass and activity caused by the use of NT instead TT. In addition, $\mathrm{C}$ and $\mathrm{N}$ mineralization were stimulated by NT as proposed in the third hypothesis.

\subsubsection{Effect of amendment}

Recently, the surface application of liming materials in NT systems has been considered a feasible alternative to the lime incorporation by tillage. However, the effectiveness of such practice to ameliorate soil acidity in depth is uncertain (Caires et al. 2008). Although our study focused on the top $10 \mathrm{~cm}$ of the soil, we observed that the beneficial effect of the amendment on soil $\mathrm{pH}$ and $\mathrm{Ca}$ content was more evident in the 0-5 cm layer than in the 5-10 cm layer in the NT-A, while the amendment effect was more homogenous within both depths in TT-A treatment.

One of the main concerns of liming amendment is the possible soil $\mathrm{C}$ depletion as a result of soil acidity amelioration and consequent stimulation of microbial activity (Paradelo et al. 2015). However, recent studies have demonstrated that the combination of liming with NT can maintain or increase the soil C contents as a consequence of soil disturbance reduction and higher biomass inputs from crop residues (Inagaki et al. 2017; Hontoria et al. 2018). In addition, unlike mineral $\mathrm{CaCO}_{3}$, sugar beet foam serves as a source of organic matter (86.7 $\mathrm{g} \mathrm{kg}^{-1}$ of organic matter, Table S-1) which could counterbalance the expected increase in the $\mathrm{C}$ mineralization. Our results demonstrated that soil $\mathrm{C}$ pools were unaffected or even slightly increased by liming, while the 
enzymatic activity was stimulated. Previous studies in the same experimental area revealed the ability of liming amendment to enhance the microbial activity in these soils (León et al. 2017) and to promote higher biomass yields in the NT and amended plots (Hontoria et al. 2018). In addition, the mineralization of $\mathrm{C}$ determined in the laboratory incubation was not affected by the liming amendment. The reduced pool of MBC caused by liming could be explained by changes in the microbial community composition towards a higher bacteria abundance resulting from the $\mathrm{pH}$ change (Rousk et al. 2010). However, the quantification of total bacteria and fungi did not show any effect caused by liming, periodic monitoring and further studies focusing on the microbial communities are required to understand the dynamic changes of $\mathrm{MBC}$ caused by liming materials.

Liming amendment increased both NNM and NN rates. These results are in agreement with Teutscherova et al. (2017) who found a stimulation of the N cycle after liming of soils from the field adjacent to the present study plot. In addition, this higher $\mathrm{NN}$ in the amended soils may reduce the effectiveness of the amendment as nitrification is one of the main drivers of further acidification in acidic soils (He et al. 2012).

Our results confirmed the usefulness of liming to ameliorate soil acidity and increase the microbial activity (measured as enzymatic activity) and $\mathrm{N}$ mineralization, although the absence of effect on $\mathrm{C}$ mineralization and $\mathrm{C}$ contents lead to the rejection of the hypothesis of higher $\mathrm{C}$ mineralization and $\mathrm{C}$ depletion after liming.

\subsubsection{SEM to explain the direct and indirect effects on $\mathrm{C}$ and $\mathrm{N}$ mineralization}

Although previous studies have addressed the effect of NT or lime application on $\mathrm{C}$ and $\mathrm{N}$ mineralization, this study goes a step further and evaluates the combined effects of both agricultural practices on $\mathrm{C}$ and $\mathrm{N}$ mineralization using SEM. Our data revealed the high correlation between all measured variables (Table 3.2.9) which is in agreement with previous meta-analysis which showed a high relation between the different predictors and soil properties used to estimate $\mathrm{N}$ mineralization (Ros et al. 2011). To improve our understanding of the soil properties and mechanism involved in $\mathrm{N}$ mineralization, the use of multivariate analyses based on mechanics approaches have been required (Ros 2012). Our results highlight the usefulness of SEM to elucidate and split the effects of different agricultural management practices on the soil $\mathrm{C}$ and $\mathrm{N}$ cycles and the microbial traits involved. 
The results suggested that the influence of Tillage was stronger than the effect of Amendment in both $\mathrm{C}$ and $\mathrm{N}$ cycling. In case of $\mathrm{C}$ mineralization, Tillage was the main source of data variability while Amendment had no effect, which was also supported by the LMM analyses. However, the differentiation between the direct and indirect pathways revealed that only the indirect pathway through the microbial parameters was significant, particularly through the MBC pool. The higher influence of Tillage on $\mathrm{C}$ and $\mathrm{N}$ mineralization could be related with the strong impact of the tillage practices on the accumulation of SOM and the size and activity of the soil microbial biomass. The absence of Amendment effect on $\mathrm{C}$ mineralization, probably caused by the negative effect of liming on MBC and weak stimulation of enzymatic activity, lead us to the rejection of the hypothesis of a possible $\mathrm{C}$ depletion risk caused by liming and the confirmation of the suitability of NT and liming amendment combination as a strategy to enhance soil C contents as proposed by Inagaki et al. (2017). Finally, both latent variables were significantly correlated, which could be explained by the interaction between both practices: higher $\mathrm{C}$ inputs in the amended treatments because of the higher biomass production, or the higher effect of Amendment in the top layer of NT plots resulting from surface amendment application instead the incorporation by plowing as in TT. However, few interactions between tillage and amendment were found in the LMM analyses, which indicates no synergistic effect of both practices.

The total effect of management practices on NNM was divided more equally between Tillage and Amendment. The effects of Tillage were indirect via MBC similarly to $\mathrm{C}$ mineralization, while in the case of Amendment, we found a significant positive direct pathway and a negative indirect pathway via MBC. From the agronomic and environmental point of view, the enhanced $\mathrm{N}$ mineralization caused by liming amendment, the lack of effect on $\mathrm{C}$ mineralization and the reduction of MBC could be interpreted as a potentially increased risk of $\mathrm{N}$ losses despite the possible positive effect on $\mathrm{N}$ availability to crops (Liao et al. 2018). This could be the case particularly during the fallow periods when there is no soil cover and when the only sinks of mineral $\mathrm{N}$ are the microbial immobilization or the nitrification.

The relevance of the size and composition of microbial population as affected by the long-term agricultural practices revealed the key role of the changes in the microbial biomass in understanding the effects of agriculture practices on the $\mathrm{C}$ and $\mathrm{N}$ cycling (Fanin and Bertrand 2016; Pommier et al. 2018). As mentioned above, the MBC was 
higher in the NT but lower in the amended plots, which can also be observed in the SEM: the pathways from Tillage and Amendment to MBC were positive and negative, respectively. The reduction of the MBC caused by liming amendment, supported also by previous studies (Vazquez et al. 2017), suppress the possible stimulation effect of liming on $\mathrm{C}$ mineralization in amended plots. In addition, the relevance of the enzymatic activity and of the shift in the microbial population (expressed by F:B) in the $\mathrm{C}$ and $\mathrm{N}$ mineralization, were lower in comparison with the $\mathrm{MBC}$, which was the only significant pathway to $\mathrm{C}$ and $\mathrm{N}$ mineralization in SEM. This confirms the results obtained by Fanin and Bertrand (2016) who found that structural population parameters as F:B are not adequate to predict changes in the $\mathrm{C}$ mineralization rates. Our study revealed that $\mathrm{C}$ mineralization looks to be more sensitive to the microbial biomass size than to the microbial structure or activity. In addition, the SEM permitted us to evaluate the direct or indirect effects of Tillage on $\mathrm{C}$ mineralization and in our case, only the indirect pathway through MBC was significant. Similarly, Colman and Schimel (2013) found that the effect of soil $\mathrm{C}$ on $\mathrm{C}$ mineralization was mediated indirectly by mean of microbial biomass. This highlight the importance of the inclusion of microbial traits in the assessment of agroecosystem nutrient cycles in order to improve the understanding of the effects promoted by the agronomic practices and to predict their environmental impacts (Pommier et al. 2018). 


\subsection{Experiment 5: Effect of NT, liming and depth on soil proteases}

\subsubsection{The effect of soil depth}

The activity of all three enzymes decreased with increasing soil depth, similarly to previous findings (Bach and Munch 2000; Taylor et al. 2002; Fuka et al. 2008), which have been related to decreasing both SOM content and microbial biomass in deeper layers of the soil profile (Bausenwein et al. 2008; Cao et al. 2008).

Unlike the majority of studies (Tian et al. 2010; Batjes 2014), we found increasing $\mathrm{C}: \mathrm{N}$ ratio with increasing soil depth, which has been found also in adjacent fields of the area of Cañamero's raña (unpublished data). These high C:N values in deeper layers can be explained by the retention of the dissolved organic carbon (DOC) by poorly crystalline iron and aluminum hydroxides and oxides, with a high specific surface area (Lorenz and Lal 2014). Thus, DOC translocation may have contributed to the formation of mineral-bound SOC in the deep layers (Schrumpf et al. 2013). Nevertheless, further investigations of the origin and composition of SOM throughout the soil profile is necessary in order to understand the implications it can have for nutrient cycling and leaching.

The activity of casein protease decreased drastically with depth while the activity of BAA protease was less influenced by soil depth, which could be linked to an accumulation of large $\mathrm{N}$ polymeric compounds near the soil surface and to distribution of small molecular weight proteinaceous compounds within the soil profile. Furthermore, the composition of the extractable SOM changed drastically with the soil depth: while the content of plant biomass-derived compounds decreased with soil depth, microbial compounds tended to accumulate in the lower layers (Kaiser and Kalbitz 2012). We observed an increasing amount of Carb $\mathrm{ex}_{\mathrm{e}}$ in the $10-25 \mathrm{~cm}$ soil layer when compared to the $0-5 \mathrm{~cm}$ or $5-10 \mathrm{~cm}$ layers, which is in good correspondence with the chromatographic system theory (Kaiser and Kalbitz 2012). In addition, the presence of perched water tables in this area between five and ten $\mathrm{cm}$ below the soil surface during the excess rain periods (Gómez-Paccard et al. 2015) supports the hypothesis of accumulation of extractable carbohydrates in the $10-25 \mathrm{~cm}$ soil layer above the $\mathrm{Bt}$ horizon. 


\subsubsection{Tillage effects on soil properties}

Increased TOC and TN contents following conversion to conservation agriculture is well accepted and has been observed in several Mediterranean agricultural sites (Aguilera et al. 2013; Mazzoncini et al. 2016; Sanz-Cobena et al. 2017); those changes have been attributed to the accumulation of plant residues together with the suppression of SOM degradation provoked by tillage. According to previous studies in the area, enhancement of both recalcitrant and labile organic $\mathrm{C}$ pools in the soil contribute to the increased TOC contents (Vazquez et al. 2017; Hontoria et al. 2018). In general, our previous studies show a stimulation of microbial biomass activity and acceleration of nutrient cycling (Vazquez et al. 2017), including enhanced Gls activity and MBC under NT plots as it has been measured in the current study. Our experimental set up allows for assessing the effects of conservation tillage compared to traditional tillage in the long-run and show that the initial effects on TOC observed three years after conversion (Hontoria et al. 2018) are sustained after more than a decade.

Unlike initially hypothesized, none of the investigated proteases seemed to be affected by the tillage practice, similarly to results obtained by Panettieri et al. (2014). Only an interaction between tillage and depth was observed for the casein protease activity (and Gls activity, both higher in the NT in the $0-5 \mathrm{~cm}$ soil layer). This pattern can be explained by the higher TN, microbial biomass and $\mathrm{N}_{\mathrm{ex}}$ contents in the upper soil layers of the NT plots, suggesting, in line with our second hypotheses, that the management effects on soil properties are localized in the uppermost $\mathrm{cm}$ of the soil profile. In addition, no additive effects of tillage and liming were found with regard to the enzymatic activities, therefore our hypothesis of synergism between agronomic practices is rejected.

Tillage showed a strong impact on the content of PMN (Fig. 1, Table 2), which seems to be related to the activity of casein protease according to the PCA (Fig. 2, Table 4). Casein protease degrades high-molecular weight organic compounds in soil and is therefore considered to be involved in the initial steps of proteolysis (PiotrowskaDlugosz 2014). The higher casein protease activity in top soil of NT likely allows for fueling the downstream N-transformation processes by an alleviation of substrate limitation, thereby increasing PMN, as shown by previous studies (Halpern et al. 2010), and probably enhancing $\mathrm{N}$ availability for crops of the NT system, which can better perform (Fig. 4.5.3) 


\subsubsection{Soil $\mathrm{pH}$ as the key factor shaping $\mathrm{N}$ transformations}

Long-term soil acidification is one of the main concerns of agriculture (Guo et al. 2010) and often leads to negative effects on microbial biomass (Wolters and Joergensen 1991; Acosta-Martínez and Tabatabai 2000) and enzymatic activity with implications for SOM decomposition and nutrient recycling (Kemmitt et al. 2006). To counteract for those deleterious effects, liming amendments have been widely applied to increase the soil $\mathrm{pH}$, reduce the Al-toxicity and enhance the crop productivity (Gómez-Paccard et al. 2013; Paradelo et al. 2015; Hontoria et al. 2018). Following its application into the soil, positive effects on $\mathrm{N}$ mineralization have been observed (Haynes and Swift 1988; Feng et al. 2003; Teutscherova et al. 2017a), probably resulting from the improvement of enzymatic activities (Acosta-Martínez and Tabatabai 2000; León et al. 2017). In the present study, the effect of liming application was strongly enzyme-specific. While the activity of Gls was not affected; casein protease activity was increased and BAA protease activity decreased following the application of liming.

There are several mechanisms by which the application of liming may affect the protease activity. The observed increase in the soil organic $\mathrm{N}$ pool may have directly stimulated proteolysis in limed soils, by an up-regulation triggered by the increase in substrate for enzymatic degradation (Geisseler and Horwath 2008). In addition, the application of sugar foam (rich in polysaccharides, with high $\mathrm{C}: \mathrm{N}$ ratio), may further stimulate the microbial requirements for $\mathrm{N}$ to meet the metabolic equilibrium in the sugar foam decomposition process (Sinsabaugh et al. 2009; Zechmeister-Boltenstern et al. 2015; León et al. 2017). Furthermore, the observed decrease in labile C forms (i.e $\mathrm{C}_{\mathrm{ex}}$ and $\mathrm{MBC}$ ), in the limed plots may have stimulated the protease activity as labile $\mathrm{C}$ fractions have been found to suppress the protease activity (Geisseler and Horwath 2008). This seems to be especially the case for the casein protease, as shown by its

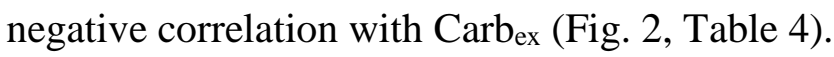

For the BAA, the picture seems to be different, and its reduced activity is probably related to the observed decrease in MBC and MBN as found by Baraniya et al. (2016). This decrease in MBC has been observed previously on these plots (Vazquez et al. 2017). This explanation is further supported by the PCA results, where MBC, MBN and BAA protease are loaded on the same axis. Similarly, the observed decrease in EEGRSP in the amended plots may be linked with the lower BAA protease activity (Gispert et al. (2013). Glomalin is a glycoprotein containing high amounts of both C 
and $\mathrm{N}$ and can contribute to the maintenance of microbial activity. The PCA supported the tight relationship between the glomalin, BAA protease and Gls (Fig. 2, Table 4) proposed by Gispert et al. (2013). The decrease of EE-GRSP in the 5-10 cm layer has been previously described by Gómez-Paccard et al. (2013), and, if we consider the production of glomalin as a mechanism to protect against Al toxicity, the lower production of these proteins were expected in the amended plots (Gómez-Paccard et al. 2013). Their implications in soil aggregate stability require further studies.

Our results point towards a shift in the $\mathrm{N}$ form available in the soil following liming, suggesting that more monomers and amino-acids are being produced, but they are not further degraded into $\mathrm{NH}_{4}{ }^{+}$, which may have further implications for plant nutrition. In the long-term, application of lime and the subsequent change in soil $\mathrm{pH}$ can lead not only to substantial changes in $\mathrm{N}$ use efficiency by soil biota, but also to a considerable alteration of the $\mathrm{N}$ acquisition preferences by plants (Liao et al. 2018). Indeed, soil microbes and plants are strongly interlinked, and plants may promote changes in the soil proteolytic activity (Vranova et al 2013) by inducing rhizosphere changes (Baraniya et al 2016) or through modifications of the substrate quality (Badalucco et al. 1996; García-Gil et al. 2004). In our case, harvested biomass showed two-fold lower $\mathrm{C}: \mathrm{N}$ ratios in limed plots, suggesting a strong change in $\mathrm{N}$ acquisition patterns but also in plant composition (e.g. higher abundance of vetch at the expense of oat). The change in plant residue quality seems to play a significant role in the ratio between casein and BAA activity (Fig 4.5.3). This suggests a higher degradation rate of large proteinaceous molecules in limed plots, which is, however, decoupled from subsequent $\mathrm{NH}_{4}{ }^{+}$production. Thus, a relatively high production of labile small protein compounds might occur, although our understanding of their fate is still limited and several pathways are suggested. For instance, small molecular weight $\mathrm{N}$ compounds are relatively mobile and could therefore be transported an accumulated in deeper soil layers or leached out (van Kessel et al. 2009). This phenomenon could be particularly important in limed plots where the lower MBC suggests lower $\mathrm{N}$ immobilization. Furthermore, amino-acids and monomers can be taken up by plant roots, especially in $\mathrm{N}$ limited ecosystems (Schimmel and Bennett, 2004). Finally, the PMN results suggest that $\mathrm{NH}_{4}^{+}$production is enhanced in amended plots despite the BAA activity being reduced. We should acknowledge that only potential activities (rather than in situ enzymatic reaction, (Nannipieri et al. 2018) of a subset of the enzymes involved in the 
protein mineralization (Nannipieri et al. 2012)) have been studied here and therefore further analysis are required to fully understand the overall effect of liming in protein mineralization. 


\subsection{Experiment 6: Effect of NT and liming on plant mycorrhization}

\subsubsection{Effect of NT and liming on soil properties}

The combination of NT with surface liming have been proposed as a suitable combination to restore acid degraded increasing the SOM and ameliorating the soil acidity (Caires et al. 2006; Joris et al. 2016; Hontoria et al. 2018). Our results confirm an increase of SOC, TN and POM contents in the topsoil of NT treatments, while liming had no effect on soil $\mathrm{C}$ and $\mathrm{N}$ fractions content. The adoption of NT reduced soil disturbance and linked soil aggregates disruption, which resulted in lower accessibility of organic C to soil microorganisms and reduced C mineralization (Six et al. 2000; Chatterjee and Lal 2009). In addition, the higher biomass production in limed NT plots also contributed to SOC enhancement due to the higher $\mathrm{C}$ input in form of stubble (Hontoria et al. 2018).

The use of POxC as an indicator of management practices in soil $\mathrm{C}$ accumulation has been increasing in the last years as it represents more processed and stabilized pools of $\mathrm{C}$ when compared to POM, which represents a partially decomposed fraction of SOM (Culman et al. 2012). The positive effect of liming on POxC, probably caused by higher crop biomass production of the limed treatments (Hontoria et al. 2018), indicates that liming does not necessarily need to cause a $\mathrm{C}$ depletion risk due to the stimulation of microbial activity and C mineralization (Paradelo et al. 2015). The lower content of EN in limed treatments was unexpected because in general, liming of acid soil stimulates the $\mathrm{N}$ mineralization and availability (Teutscherova et al. 2017a; Liao et al. 2018) and therefore, higher EN should be expected in the limed plots. Nevertheless, since the lime application had the strongest effect on $\mathrm{EN}$ at the end of the growing season, we could conclude that lime application may have stimulated an early mineralization of SOM and stubble which increased the $\mathrm{N}$ availability at early growth stages, while the highest $\mathrm{N}$ availability in control plots was observed later in the growing season. Similar findings have been previously observed also by Liao et al. (2018).

Unlike other studies (Madejón et al. 2009; León et al. 2017; Vazquez et al. 2017), we did not observe any effect of soil tillage on the activity of assayed enzymes. The majority of studies (Madejón et al. 2009; León et al. 2017; Vazquez et al. 2017) found marked stratification of enzyme activities under NT with the strongest effect observed in the top soil $(0-5 \mathrm{~cm})$ layer, which could explain the lack of tillage impact in the 
present study where enzyme activities may have been diluted due to $0-10 \mathrm{~cm}$ sampling layer. On the other hand, liming increased DHase activity which is in accordance with previous studies (León et al. 2017; Vazquez et al. 2017) and this positive effect could be attributed to the amelioration of $\mathrm{Al}^{3+}$ toxicity and a general improvement of the microbial activity.

As previously described by Hontoria et al. (2018) the liming amendment used in the present study was composed of sugar beet foam and red gypsum and increased the soil $\mathrm{pH}$ up to $6 \mathrm{pH}$ units, which is above the common threshold $(\mathrm{pH} \leq 5.5)$ which limits the $\mathrm{Al}^{3+}$ phytotoxicity (Meriño-Gergichevich et al. 2010). Furthermore, the application of lime provides $\mathrm{Ca}$ cations which generate $\mathrm{OH}^{-}$anions raising the soil $\mathrm{pH}$ and leading to $\mathrm{Al}$ precipitation in form of insoluble hydroxides and $\mathrm{Al}^{+3}$ toxicity amelioration (Haynes and Naidu 1998; Meriño-Gergichevich et al. 2010). In addition, the sugar beet foam was rich in $\mathrm{Mg}$ (47.3 $\mathrm{g} \mathrm{MgO} \mathrm{kg}^{-1}$ ) which promoted an increase of Mg availability in the limed soils. Thus, the application of sugar foam waste together with red gypsum was confirmed to substantially increase plant growth due to acidity alleviation while also proving both $\mathrm{Ca}$ and $\mathrm{Mg}$ for adequate plant nutrition (Fageria and Baligar 2008; Meriño-Gergichevich et al. 2010; Hontoria et al. 2018). Although previous studies in the same experimental area observed no differences in liming effectiveness in deeper soil layers between surface lime application and lime incorporattion (Hontoria et al. 2018), we found higher $\mathrm{Ca}$ and $\mathrm{Mg}$ contents under NT which could indicate delayed movement of these nutrients downwards the soil profile.

Despite the high available $\mathrm{P}$ content in all treatments (> $100 \mathrm{mg} \mathrm{P} \mathrm{kg}{ }^{-1}$ ), the $\mathrm{P}$ content was further increase by liming as described by other studies (Fageria and Baligar 2008). After 11 years of fertilizing with $72 \mathrm{~kg} \mathrm{P} \mathrm{ha}^{-1}$ per year, a great accumulation of $\mathrm{P}$ available was observed which suggest a further accumulation of $\mathrm{P}$ in non-available forms. Previous studies have found a similar accumulation of available $\mathrm{P}$ (and non-available P) in Acrisol after several years of fertilizing because of the high $\mathrm{P}$ fixation of these soils and the lower crop productivity and $\mathrm{P}$ uptake which is always lower than the amount of applied fertilizer (Guo et al. 2000; Allen et al. 2006; Redel et al. 2007). 


\subsubsection{Plant growth and AMF root colonization}

The oat plant biomass (expressed in $\mathrm{g} \mathrm{plant}^{-1}$ ) was higher under NT and liming when compared to TT and control, respectively, while vetch growth was only increased by liming. The increased plant size, together with higher nascence, in the NT resulted in the highest crop biomass harvest in NT-A treatment, which was two orders of magnitude higher than in TT, where the produced (vetch and oat) biomass was lower than $100 \mathrm{~kg} \mathrm{ha}^{-1}$. These extreme differences were caused by the very low nascence of oat and vetch in TT (9 and 2\%, respectively) and high proportion of weeds in the TT plots. The low nascence in TT have been previously described in Gomez-Paccard et al. (2015) and it has been related with the deficient water drainage under tillage and the continuous waterlogging periods during the winter months (during the study season, $211 \mathrm{~mm}$ between 28 December and 11 January). In addition, the higher vetch nascence in liming could be caused by the increase of soil $\mathrm{pH}$ above the critical soil $\mathrm{pH}$ threshold $(\mathrm{pH}>5.9)$ for vetch growth (Goulding et al., 2016). On the other hand, liming improved the growth of both crop species due to the alleviation of $\mathrm{Al}^{3+}$ phytotoxicity (MeriñoGergichevich et al. 2010) and the increase of available nutrients. In addition, soil pH neutralization could have stimulated SOM mineralization and increased $\mathrm{N}$ availability (Teutscherova et al. 2017a) and $\mathrm{N}$ uptake by crops (Liao et al. 2018). This could also explain the higher oat biomass and N content in NT-A where the accumulated SOC and TN were the highest. Furthermore, liming could have enhanced the $\mathrm{N}_{2}$ fixation by vetch, because the most of the rhizobia strains are sensitive to soil acidity and the nodulation is reduced below pH 6 (Hungria and Vargas 2000). Therefore a higher $\mathrm{N}_{2}$ fixation could be expected in the limed treatments. This could explain the higher $\mathrm{N}$ content of vetch and the higher N:P ratio. Finally both NT and liming had a strong effect on AMF root colonization, which could be also related with the higher plant growth and $\mathrm{N}$ content.

The mycorrhizal root colonization of both oat and vetch plants was significantly increased by NT and liming which confirms our hypothesis. The preservation of the intact fungal mycelium under NT increases the amount of AMF propagules which promotes faster and more efficient plant-AMF symbiosis in the early stages of crop development (Brito et al. 2012; Verzeaux et al. 2017). In addition, liming increases soil $\mathrm{pH}$, reduces the $\mathrm{Al}^{3+}$ and lead to a better root growth and plant fitness, increasing the $\mathrm{C}$ supply for plant-AMF symbiosis establishment and maintenance (Borie and Rubio 
1999; Moreira et al. 2010; Cruz-Paredes et al. 2017). The synergistic effect of NT and liming was observed in the colonization of oat roots and the highest colonization was observed in NT-A plots. The differences between treatments were evident since the first sampling (123 DAS) until the end of the experiment. The root colonization of vetch was also higher $(\mathrm{p}<0.05)$ in NT in the early growth stages and could explain the higher $\mathrm{N}$ content in the young vetch seedlings under NT. The root colonization by AMF at earlier stages of growth have been found to be a fundamental mechanism of $\mathrm{Al}^{3+}$ toxicity and $\mathrm{P}$ deficiency alleviation(Beggi et al. 2016; Seguel et al. 2016b) and of the enhancement of $\mathrm{N}$ acquisition during that first crop stages, leading to a higher plant growth during the further crop development (Sorensen et al. 2008). In our case, the higher AMF colonization in NT may have helped the plants to alleviate the $\mathrm{Al}^{3+}$ toxicity in the nonlimed treatments.

Although high available $\mathrm{P}$ content usually translates into low mycorrhizal colonization because plants do not need to invest $\mathrm{C}$ in form of carbohydrates to sustain the fungi suppressed (Smith and Read 2008; Sorensen et al. 2008), we found high colonization of both crops during the whole growing season. On the contrary, plant growth could be hindered as a result of unidirectional flow of $\mathrm{C}$ to fungi without evident benefit for the plant. Because we found the highest root colonization in the treatments with the best plant performance in terms of biomass production and nutrient uptake, we could conclude that plants obtained other benefits from the symbiosis. Plants can promote high mycorrhizal root colonization even in soil with high $\mathrm{P}$ availability, in case of deficiency of other nutrient, such as often N (Nouri et al. 2014). This hypothesis could be plausible as the highest plant $\mathrm{N}$ contents in oat and vetch were observed in the treatments with higher root colonization, aboveground plant biomass and $\mathrm{N}$ content. Nevertheless, the N:P ratio in biomass was increased by liming in vetch and by both liming and NT in oat, which could also be caused by the alteration of $\mathrm{N}$ availability resulting from the alteration of soil microbial activity. To disentangle the impacts of agronomic practices on soil microbial communities and nutrient cycling from the impacts on mycorrhizal symbiosis remain challenging in the field experiments due to the unavailability of non-mycorrhizal plant controls.

There are several mechanisms by which AMF can enhance the $\mathrm{N}$ acquisition by crops: (i) AMF exhibit higher competitivity take up $\mathrm{NH}_{4}{ }^{+}$when compared to plant rootsand, therefore, directly increase the $\mathrm{N}$ acquisition (Pérez-Tienda et al. 2012), and 
(ii) AMF stimulates the SOM mineralization by mean of changes in the microbial decomposer populations increasing the availability of mineral $\mathrm{N}$ and therefore, the acquisition of $\mathrm{N}$ from organic sources after mineralization (Leigh et al. 2009; Herman et al. 2012). We observed increased DHase activity in limed plots, which is generally well correlated with microbial respiratory activity and, thus, with the active microbial communities, similarly to the results of previous studies (Vazquez et al. 2017). Nevertheless, the separation of the possible effects on $\mathrm{N}$ mineralization caused by AMF and by the inherent changes in soil properties caused by management as well as from those caused by other biotic and abiotic factors remains to be addressed. Nevertheless, no differences were detected in the activity of soil Glm, probably because of limitation of NT and lime effect to the upper soil layer $(0-5 \mathrm{~cm})$ as observed by (Vazquez et al. 2017). Although the activity of Glm has been proposed to be a possible indicator of AMF (García-González et al. 2016), we did not find any relationship between mycorrhizal root colonization and Glm activity, and the lack of effect of NT and liming on GIm contrasted with the strong effect on AMF root colonization.

The role of AMF in $\mathrm{N}$ acquisition in mixed crops between leguminous and nonleguminous plants remains largely unclear and deserves more attention. Firstly, the AMF have been found to play a key role in the tripartite symbiosis among leguminous plant, AMF and rhizobium enhancing the efficiency of the symbiosis and plant growth (Barea et al. 2006). However, the benefits of the tripartite symbiosis are more evident under low $\mathrm{P}$ availability when the role of AMF to supply $\mathrm{P}$ is crucial (Mortimer et al. 2008). In our case, the high $P$ availability level in all the treatments probably reduces the importance of AMF in such tripartite system. In fact, no differences were found in the vetch $\mathrm{P}$ content among treatments. Furthermore, AMF can play a key role in the intercropping of legume and non-legume crops, enhancing the transfer of the $\mathrm{N}_{2}$ fixed by legume to the non-legume crop (Jalonen et al. 2009; Meng et al. 2015). This could possibly explain higher oat $\mathrm{N}$ content in the treatments with the highest root colonization. To confirm this hypothesis, ${ }^{15} \mathrm{~N}$ analysis would be required in order to quantify the magnitude of the transfer from leguminous to non-leguminous crop (Jalonen et al. 2009).

Finally, the synergistic effect of NT and liming on total harvested biomass (oat and vetch, without weeds) and total uptake of $\mathrm{P}$ and $\mathrm{N}$ demonstrated NT and liming combination to be a promising strategy to enhance the $\mathrm{N}$ and $\mathrm{P}$ uptake by crops which 
could help to increase the fertilizer use efficiency, reduce the amount of required fertilizers and mitigate the negative environmental impacts of agriculture while simultaneously promoting higher crop yields. 


\subsection{General discussion}

Recently, application of more sustainable agricultural practices such as NT combined with surface lime application has been identified as capable of restoring the fertility of degraded acid soils. The combination of NT and liming restored the SOC pools, improved soil physical properties and soil-water relationships, alleviated the acidity and $\mathrm{Al}^{3+}$ toxicity, mitigated GHG emissions and increased crop yields (GómezPaccard et al. 2013, 2015; García-Marco et al. 2016; Hontoria et al. 2016, 2018). Nevertheless, as several important aspects of NT and lime application were detected to be unclear, this thesis aimed at filling these gaps and at identifying the interactive effects of NT and liming on soil microbial activity and nutrient transformations with a special emphasis on the particular seasonality of the Mediterranean climate.

In particular, six gaps of knowledge were identified in the literature prior to this thesis and these were targeted by tailor-designed experiments focusing on: (i) soil biological properties and their evolution during the year under Mediterranean climate in order to identify the different effects of studied practices in different seasons, (ii) the impact of NT and liming on N transformation during the summer fallow period and (iii) the subsequent rewetting event, (iv) the combined effect of both practices on $\mathrm{C}$ and $\mathrm{N}$ mineralization and (v) soil protease activity and $\mathrm{N}$ availability, and (vi) the AMF-plant interaction and nutrient uptake. To address these under-investigated topics, six different objectives were formulated each with proposed hypotheses. Six different experiments were designed and performed in the long-term an experimental field located in the Cañamero raña in Cáceres (SW Spain) where NT (versus TT) and liming were tested as factors in full-factorial split-plot design.

\subsubsection{Were the hypothesis accurated and the result consistent through the different experiments?}

As the objectives and hypothesis were interlinked, several hypotheses were addressed by various experiments; therefore the combined evaluation of the results obtained in the six experiments is necessary to confirm the proposed hypothesis. Then, the proposed hypotheses for each objective have been summarized (Table 5.1) and in those hypotheses which were rejected totally or partially, a brief explanation of the obtained result will be presented. After that, the main hypothesis will be discussed jointly to confirm the consistence of the result obtained in each experiment. 
Table 5.1. Summary of proposed hypothesis for each objective and the justification of the obtained results. In blue, the confirmed hypothesis, in black those partially confirmed and in red the rejected hypothesis..

OBJECTIVE 1: Detection of combined effects of NT and liming on microbial and EAs and their fluctuations derived from the seasonality of Mediterranean climate
$\checkmark$ H1a:
Biological parameter will be affected by NT and liming through the impact on
$\checkmark$ H1b: soil properties
The magnitude of the impact will be determined by abiotic conditions derived from seasonality

OBJECTIVE 2: Gross $\mathrm{N}$ transformation rates during summer fallow and underlying mechanisms

$\pm \mathrm{H} 2 \mathrm{a}$ : $\quad$ Combination of NT and liming will stimulate gross $\mathrm{N}$ mineralization and nitrification and will results in accumulation of mineral $\mathrm{N}$ in soil

$\rightarrow$ NT had low effect on gross transformation rates (interaction TxA only on gross $N$ mineralization)

$\times \quad H 2 b$ : High amount of labile C in NT will enhance N immobilization

$\rightarrow$ NT had no effect on $N$ immobilization

$\checkmark$ H2c: $\quad$ N transformation rates will decrease in time and will results in decoupling between ammonification and nitrification

OBJECTIVE 3: NT and liming will reduce the after-rewetting $\mathrm{N}_{2} \mathrm{O}$ emissions after summer fallow

\pm H3a: $\quad$ Liming will reduce the emissions and the magnitude will depend on tillage practice and moisture content

$\rightarrow$ Liming reduced $\mathrm{N}_{2} \mathrm{O}$ emissions but tillage had no effect

$\pm \mathrm{H} 3 \mathrm{~b}$ : $\quad$ Liming will increase the abundance of denitrifiers and AOB but reduce abundance of AOA

$\rightarrow$ Liming did not influence AOA

$\pm \quad \mathrm{H} 3 \mathrm{c}: \quad$ Liming will increased the transcription of denitrifiers and AOB but reduce the transcription of AOA

$\rightarrow$ Liming increased the transcription of nirK but the transcription of other genes was not detected

OBJECTIVE 4: Identification of direct and indirect effect effects of NT and liming on C and N mineralization using SEM
$\checkmark$ H4a:
NT will increase of SOC and will enhance microbial biomass and activity
$\checkmark$ H4b:
Liming will alleviate soil acidity and stimulate the microbial and enzymatic
\pm H4c:
$\checkmark$ H4d:
activity
$\mathrm{C}$ and $\mathrm{N}$ mineralization will be accelerated by both practices
$\rightarrow$ Liming affected only mineralization of $N$
H4d: $\quad$ SEM will reveal

OBJECTIVE 5: Evaluation of protease activity in different soil layers as affected by NT and liming

$\times$ H5a: $\quad$ Liming and NT will synergically increased the activity of both protease groups

$\Rightarrow$ No synergistic effects were found, each practices affected different parameters

$\checkmark$ H5b: $\quad$ The effect of NT and liming will be limited to the upper soil layers

OBJECTIVE 6: Evaluation of the effect of NT and liming on mycorrhizal symbiosis in oat-vetch mixed cropping system
$\checkmark$ H6a:
NT and liming combination will increase growth and nutrient uptake of both plant species
$\checkmark$ H6b:
root colonization by AMF will be higher under NT and liming combination
$\checkmark$ H6c: The strongest effect of NT and liming on root colonization will be observed in early growth stages 
The impact of NT and liming on soil microbial indicators under the influence of the Mediterranean seasonality was evaluated in the EXPERIMENT 1, where we observed a general increase of soil EAs under NT, which was linked with the higher SOC accumulation and the amelioration of drought stress increasing soil moisture and maintaining relatively stable temperature. This positive effect of NT on EAs was also confirmed in the EXPERIMENT 5 where casein protease and Gls were higher in NT than in TT.

The effect of liming on EAs was generally lower when compared to tillage practices and only DHase, Gls and PHase were increased by liming in the EXPERIMENT 1. On the other hand, in EXPERIMENT 5 soil proteases were strongly affected by lime application. This lower effect of liming or EAs respect to tillage practices was confirmed by the SEM performed in the EXPERIMENT 4, where the direct effect of Tillage on Gmean was higher than Amendment effect. Finally, we did not find the expected interaction between NT and liming on any of the EAs determined with the exception of DHase.

The effect of NT and liming on MBC were opposite and while NT increased MBC, liming caused its overall reduction. This result was found in EXPERIMENT 1 and EXPERIMENT 5, and partially in EXPERIMENT 2 where only NT increased the MBC. The positive effect of NT on MBC has been largely demonstrated (Madejón et al. 2007, 2009; Martín-Lammerding et al. 2015) and can be justified similarly as the positive effect of NT on EAs. In addition, the total bacteria and total fungi were quantified in EXPERIMENT 2 and 4, showing a positive effect of NT, which confirms an increase of microbial population under NT. Furthermore, the higher AMF colonization in NT found in EXPERIMENT 6 suggested a higher development of AMF mycelia due to the lack of mycelia disruption by tillage and/or increase of AMF propagules.

On the other hand, the reduction of MBC by liming could be related to changes in the structure of microbial communities towards higher relative abundance of bacteria (respect to fungi) caused by $\mathrm{pH}$ neutralization (Rousk et al. 2010) This was detected in the EXPERIMENT 2 but not in the EXPERIMENT 4 where the $\mathrm{F}: \mathrm{B}$ ratio was unaffected by liming. These contradictory results confirmed the high impact of Mediterranean seasonality on microbial parameters found in EXPERIMENT 1. 
The impact of NT and liming on gross $\mathrm{N}$ transformation during the summer fallow was mainly addressed in the EXPERIMENT 2 as a logically continuation of EXPERIMENT 1, where the strong impact of studied practices was detected during the summer fallow period. Similar findings of high EAs under drought and heat stress were confirmed by EXPERIMENT 2 and gross $\mathrm{N}$ transformation rates were not limited even under such harsh conditions. In addition, the observed stimulation of gross $\mathrm{N}$ mineralization by liming was supported by the results of EXPERIMENT 4 where liming had a strong impact on NNM according to SEM analysis. In addition, the gross nitrification stimulation by tillage could be supported by the increase of AOB abundance in limed treatments as also observed in EXPERIMENT 3.

The EXPERIMENT 4 aimed to clarify the role of tillage practices and liming application on $\mathrm{C}$ and $\mathrm{N}$ mineralization and to confirm the results obtained in the other experiments. SEM showed that $\mathrm{C}$ mineralization was only affected by tillage practice, while $\mathrm{N}$ mineralization was affected both by tillage and liming. This was also partially confirmed in other experiments, where mainly EAs involved in $\mathrm{N}$ cycling were affected by liming while tillage influenced the EAs in general (see EXPERIMENT 1 and EXPERIMENT 5). In addition, the strong impact of liming on $\mathrm{N}$ cycle is supported by EXPERIMENTS 2 and 3 where liming determined the gross $\mathrm{N}$ transformation rates and post-rewetting $\mathrm{N}_{2} \mathrm{O}$ emissions.

In addition, the reduction of MBC caused by lime application was found to play a key role in $\mathrm{C}$ mineralization as revealed the SEM. The MBC was the best direct driver of $\mathrm{C}$ mineralization, and the decrease of MBC caused by liming suppressed the possible effects of liming on $\mathrm{C}$ mineralization. This result, together with no impact of liming on the content of several $\mathrm{C}$ fractions in the soil, confirmed that liming in the study area does not lead to SOC depletion risk, which was found by other studies (Paradelo et al. 2015). The absence of SOC depletion could be caused by the surface application of lime instead of tillage incorporation and the higher biomass production of the NT-A treatment as found in EXPERIMENT 6 or previously described by Hontoria et al. (2018).

While the rest of the mainly hydrolytic enzymes were studied in the EXPERIMENT 1, the activity of soil proteases was evaluated separately in EXPERIMENT 5 due to its crucial role in $\mathrm{N}$ cycling. As the proteolysis is considered a bottleneck of $\mathrm{N}$ cycling (Weintraub and Schimel 2005), the activity of proteolytic 
enzymes in the whole rooting depth could be essential for crop $\mathrm{N}$ uptake. In the EXPERIMENT 1, however, the strongest effect of NT on EAs was constrained only to the upper-most $(0-5 \mathrm{~cm})$ soil layer, which confirms the previously described stratification of soil profile (Madejón et al. 2007, 2009; López-Garrido et al. 2014) as one of the main characteristics of NT (Franzluebbers 2002). Similarly, in EXPERIMENT 6, we observed no effect of NT on Glm, possibly due to deeper sampling $(0-10 \mathrm{~cm})$, which could be also applied to similar SOC and TN content under TT and NT found in EXPERIMENT 2, 3 and 6.

Additionally, the impact of tillage practices on $\mathrm{C}$ cycle parameters and the effect of liming on $\mathrm{N}$ parameters was in line with the result obtained in EXPERIMENT 1 and 4. This highlights the suitability of NT and liming combination to increase the SOC content and at the same time, increase the availability of $\mathrm{N}$ for crops which could explain the positive effect of liming on plant $\mathrm{N}$ content in EXPERIMENT 6.

The positive effect of NT on arbuscular mycorrhizal symbiosis was expected based on other experiments (Borie et al. 2006; Dai et al. 2015; Wang et al. 2016) as well as from the present study site. For example, (Gómez-Paccard et al. 2013) observed higher GRSL under NT, which clearly indicated higher abundance or activity of mycorrhizal fungi. The possible increase of AMF propagules under NT was also supported by the increase of total fungi population in soil observed in EXPERIMENT 2 and EXPERIMENT 4. Further, the increase of plant $\mathrm{N}$ content in limed treatments could be related with the increase of $\mathrm{N}$ mineralization largely demonstrated in other experiments, or by increased mycorrhizal root colonization (as demonstrated in EXPERIMENT 6), which facilitated $\mathrm{N}$ uptake.

Altogether, the results obtained in each individual experiment were supported or complemented by the results from other experiments. Nevertheless, few contradictions were found which could be related with differences in the sampling period (as hypothesized in EXPERIMENT 1), which strongly affected the microbiological parameters under the Mediterranean seasonality. In addition, the evaluation of all experiments together helped to obtain a holistic view of the relations among studied variables under the influence of NT and liming under Mediterranean climate. 


\subsubsection{Which are the main implications of the obtained results?}

Globally, this thesis addresses the impact of the NT and liming combination in soil microbial properties and the $\mathrm{C}$ and $\mathrm{N}$ cycle. Although several studies have evaluated the impact off NT and liming combination on some microbial parameters (Tabatabai 2003; Inagaki et al. 2016; León et al. 2017), this thesis has evaluated holistically different soil microbial indicators under different conditions and has applied different analytical approaches. Therefore, discussion of the obtained results can be done globally.

In general terms, the combination of NT and liming increases the microbial activity and stimulates the $\mathrm{C}$ and $\mathrm{N}$ cycling, although the role of liming deserves attention because of the decrease observed in MBC. However, we have not found any deleterious effect of the decrease of MBC by liming, probably because if this was caused by a shift in the $\mathrm{F}: \mathrm{B}$, the overlap of functionality between bacteria and fungi did not affect the decomposition process as proposed by (Rousk et al. 2008). Therefore, this thesis showed that the combination of NT and liming restores the microbial activity in acid degraded soils, which linked with the other benefits previously studied, and confirms the suitability of both practices combination to restore acid degraded soils.

Other important implication of the present thesis is the higher microbial parameters obtained in NT during the water deficient periods. The positive effect of NT in soil moisture and soil temperature has been described previously (Fabrizzi et al. 2005; Bescansa et al. 2006; Cantero-Martínez et al. 2007; Dahiya et al. 2007; GómezPaccard et al. 2015; Vita 2016; Brunel-Saldias et al. 2018). This could be considered as an amelioration of soil microbial stress because extreme drought conditions. A similar effect has been described when organic amendments are applied to soil and the increase of soil moisture retention enhances the soil microbial resilience to drought (Hueso et al. 2011; Franco-Andreu et al. 2017). The results obtained in this thesis confirm the suitability of NT to maintain soil microbial activity during drought periods, which is appreciated in a climate change scenario, in which longer and more extreme drought events are expected in the region (Varela-Ortega et al. 2016)

As expected, few interactions have been found in soil microbial parameters between NT and liming. Instead, NT increased mainly the parameters related with the C cycle and accumulated SOC, while liming affected the $\mathrm{N}$ cycle and stimulated the $\mathrm{N}$ mineralization. The distinction between the effect of NT and liming highlights the 
benefits of their combination in order to maintains the soil microbial stoichiometry. Based on the theory proposed Schimel and Weintraub (2003): the NT treatment could promote a N-limitation for decomposers and increase the respiration of $\mathrm{C}$ overflow. Instead, the TT-A could stimulate the accumulation of available $\mathrm{N}$, reducing the $\mathrm{N}$ use efficiency by microorganism and increasing risk of $\mathrm{N}$ losses. Therefore, the combination of NT and liming increases both $\mathrm{C}$ and $\mathrm{N}$ availability for microorganism and maintain the $\mathrm{C}$ and $\mathrm{N}$ microbial stoichiometry reducing the $\mathrm{C}$ or $\mathrm{N}$ outputs from the system.

The results of EXPERIMENT 2 suggested a stimulation of $\mathrm{N}$ cycle by liming during the summer fallow which could lead to $\mathrm{N}$ losses after rewetting in form of gaseous losses or leaching. The EXPERIMENT 3 was designed to address the possible impact of $\mathrm{N}$ cycle stimulation by liming during the summer fallow in form of $\mathrm{N}_{2} \mathrm{O}$.

In EXPERIMENT 3 we observed impact of liming on the nitrifier and denitrifier communities and the denitrification process, which was reflected in suppressed $\mathrm{N}_{2} \mathrm{O}$ emission after rewetting. Instead, our data suggested an increase of $\mathrm{N}_{2}: \mathrm{N}_{2} \mathrm{O}$ ratio by liming, although this could not be evaluated experimentally in the present study. Therefore EXPERIMENT 3 revealed that the potential negative environmental impacts in form of $\mathrm{N}_{2} \mathrm{O}$ emissions caused by liming are not supported by enhanced $\mathrm{N}_{2} \mathrm{O}$ emissions. This result is in line with the obtained by García-Marco et al. (2016) where liming mitigated the $\mathrm{N}_{2} \mathrm{O}$ during the crop season in the same experimental field. In addition, the higher $\mathrm{N}$ acquisition by oat and vetch plant and the higher $\mathrm{N}$ uptake at harvest in limed treatments also suggest a higher efficiency in the use of $\mathrm{N}$ by crops. Furthermore, liming increased vetch biomass which can be related higher $\mathrm{N}_{2}$ fixation. Altogether, suggests a reduction of environmental impacts in the agrosystem and higher efficiency in the use of the $\mathrm{N}$ fertilizers applied, mainly in the NT-A where the yields were the highest.

The main implications of this thesis are that the combination of NT and liming is a suitable alternative to restore acid degraded soils increasing their microbial activity, water availability for crops and microorganism and $\mathrm{N}$ availability for crops. In addition, the combination of NT and liming increased the crop yields and reduced the environmental impact of agriculture after the soil rewetting, critical in the Mediterranean agrosystem. Therefore, based on the previous studies performed in the same study field, the combination of NT and liming is an agronomic combination 
suitable to restore the chemical, physical and microbial properties of an acid degraded soil, increasing at the same time the crop yields and reducing some of the negative impacts of agriculture.

\subsubsection{Which further studies are required?}

The results obtained in this thesis have suggested new questions and gaps of knowledge which should be addressed in the future. One of the main results obtained in the thesis is the increase of EAs in NT during the period with water deficit. However, the adequacy of the method used to quantify EAs during those periods should be evaluated. During the thesis, all the EAs were analyzed by potential methods in which the conditions for the EA were the optimal. However, this methodology in which the in situ constrain (drought and heat) are suppressed could hinder the effect of drought in the soil microbial activity and overestimate the EAs during the summer. Methods to measure in situ the EA should be used in further experiments to evaluate the microbial activity in the future under Mediterranean conditions where the soil moisture is generally suboptimal. According to Wallenstein and Weintraub (2008), some alternative to assess the EA in situ are genomic studies targeting the functional genes coding for enzymes production which can identify the potential of the microbial communities to produce enzymes or studies focused in the transcription of those functional genes to assess the microbial regulation of enzyme production. In addition, the application of mass-spectrometry approaches using isotope labelling of enzyme substrates could be used to quantify the rates of enzymatic degradation. These methods would help to confirm the increase of soil microbial resilience to drought and would help to assess correctly the impact of the expected climate change on soil microbial activity. In addition, the contrasting effect of liming on protease activity should be further studied by mean of molecular approaches targeting the genes coding the protease production (Baraniya et al. 2016) and evaluating the gross protein degradation rates using amino acid pool dilution techniques (Noll et al. 2019).

In addition, the capacity of NT to reduce the water stress for crops and microbes during the periods of water deficit should be addressed including drought and heat simulation approaches as described by Sardans et al. (2008). This would enhance our knowledge about the suitability of NT in a climate change scenario.

The low effect of tillage practice on gross $\mathrm{N}$ rates could be caused by use of sieved samples which hinder the effect of soil structure in gross $\mathrm{N}$ rates, therefore some 
studies should be performed using ${ }^{15} \mathrm{~N}$ pool dilution technique with intact soil cores as described by Díaz-Pinés et al. (2017). In addition, the evaluation of other periods of the year would help to understand the overall effect of both practices. Particularly, the higher GWC during spring observed in NT could increase the gross $\mathrm{N}$ mineralization and nitrification increasing the $\mathrm{N}$ availability for crops. The gross $\mathrm{N}$ rates should be also evaluated after the first autumn rains to complete the understanding of the $\mathrm{N}$ cycle during the rewetting events.

All these proposals should be combined with the in-situ measurements of $\mathrm{N}_{2} \mathrm{O}$ emission after rewetting in order to confirm the results obtained in the laboratory and quantify the magnitude of the $\mathrm{N}_{2} \mathrm{O}$ peak. In addition, the mitigation of $\mathrm{N}_{2} \mathrm{O}$ emission by liming was related with a higher or more efficient reduction of $\mathrm{N}_{2} \mathrm{O}$ to $\mathrm{N}_{2}$ in EXPERIMENT 3, however, that hypothesis was not confirmed because $\mathrm{N}_{2}$ was not measured. Therefore, the combined measurement of $\mathrm{N}_{2} \mathrm{O}$ and $\mathrm{N}_{2}$ after rewetting would help to understand the mechanism underlying the decrease of $\mathrm{N}_{2} \mathrm{O}$ emission by liming and estimate the $\mathrm{N}$ gaseous losses after rewetting.

Finally, the stimulation of $\mathrm{N}$ cycling by liming has been proposed as an indicator of higher $\mathrm{N}$ availability for crops and related with the higher $\mathrm{N}$ content of crops in EXPERIMENT 6. To confirm this hypothesis, the $\mathrm{N}$ use efficiency should be addressed by mean of a ${ }^{15} \mathrm{~N}$ recovery experiment as described by Karwat et al. (2017) or Guardia et al. (2018).At the same time, the hypothesis suggested in EXPERIMENT 6 of a higher $\mathrm{N}_{2}$ fixation by vetch in the limed treatments, should be confirmed analizing the ${ }^{15} \mathrm{~N}$ natural abundance signature as described by Polania et al. (2016). In the same study the $\mathrm{N}$ transfer between vetch and oak by mean of AMF network could be evaluated as described by (Jalonen et al. 2009).

Altogether would confirm some of the results obtained during this thesis using more accurate methods and would increase our knowledge about the fate of the $\mathrm{N}$ mineralized. This would enhance the fertilizer and crop management in order to reduce the negative environmental impact of agriculture. 


\section{CONCLUSIONS}

The impact of NT and liming on soil microbial indicators and $\mathrm{C}$ and $\mathrm{N}$ cycling under Mediterranean climate was evaluated thought six independent experiments designed to address six different objectives in the present thesis. The main conclusions obtained at each experiment were:

\subsection{Experiment 1: Seasonal variation of enzymatic and microbial activity}

The evaluation in long-term of the field trial in the acid degraded soil of the Cañamero's raña showed that the combination of NT and liming application resulted in higher soil $\mathrm{pH}$ and SOC accumulation. However, no synergistic interactions were found in any of the microbial parameters studied. The absence of negative effects of liming on any biological parameter and the increase of DHase resulting from the alleviation of soil acidity confirm the feasibility of SF as a liming material allowing the recycling of an industrial waste and offering the farmers a cheap alternative to the conventional liming material.

The NT led to a higher microbial activity and EAs caused by (i) the increase of the SOC, and (ii) by the amelioration of the extreme drought during several water deficient months. Indeed, the highest differences in microbial activity between TT and NT were found in July, which corresponds to the summer fallow due to extreme temperatures and drought. The higher soil moisture and the lower temperatures of the NT plots during the spring and the beginning of summer could explain the maintenance of soil biological activity during summer. This capacity of NT to increase soil resistance to drought disturbance could gain on importance on the future scenery of climate change where more intense, frequent and longer droughts and heat waves may happen in the south-western Spain. In this context, the higher microbial activity under NT under drought and hot conditions might decrease the SOM potential accumulation of NT and lead to an increase of the $\mathrm{N}$ losses during summer and early autumn rainfall events. Therefore, the future research focusing on Mediterranean areas should count with exhaustive sampling schedules including great variety of condition throughout the year to evaluate the global effects of the tillage practices in the microbial activity and their consequences in the bio-geo-chemical cycles. 


\subsection{Experiment 2: Gross $\mathrm{N}$ transformation rates during summer fallow}

To our best knowledge, this is the first study which evaluates the effect of the combination of NT and liming on gross $\mathrm{N}$ transformation rates in soil during the summer fallow under Mediterranean conditions. The liming application increased both gross mineralization and gross nitrification whereas the $\mathrm{N}$ immobilization remained unaffected. These results strongly suggest a decoupling between $\mathrm{NH}_{4}{ }^{+}$production and consumption processes which could enhance the risk of soil $\mathrm{N}$ losses. This phenomenon was increased in the NT-A plots where the gross mineralization reached the highest rates while the $\mathrm{N}$ immobilization was lower than in the TT plots.

All $\mathrm{N}$ transformation rates decreased when the availability of water was low. However, $\mathrm{NH}_{4}{ }^{+}$consumption pathways were more heavily suppressed than $\mathrm{NH}_{4}^{+}$ producing pathways, leading to an accumulation of $\mathrm{NH}_{4}{ }^{+}$in the soil during the fallow period. The overall decrease of the $\mathrm{N}$ transformation rates was further supported by the drop of AOA, AOB and total bacteria abundance between May (spring) and July (summer). Strong suppression of gross nitrification rates minimizes the risk of significant $\mathrm{N}_{2} \mathrm{O}$ losses during summer fallow, but potential implications of soil $\mathrm{NH}_{4}^{+}$ accumulation after rewetting are still not fully clarified. Further studies are required to evaluate the possible effects of liming stimulation of gross $\mathrm{N}$ mineralization and nitrification during the summer fallow in the subsequent rewetting, which could lead to enhanced $\mathrm{NO}_{3}{ }^{-}$leaching and $\mathrm{N}_{2} \mathrm{O}$ emissions. Our results highlight the need to evaluate also the implications of each agronomic practice and their combinations in the $\mathrm{N}$ cycle during the summer fallow in order to evaluate the trade-offs of each agronomic management.

\subsection{Experiment 3: Post re-wetting soil $\mathrm{N}_{2} \mathrm{O}$ emissions}

To the best of our knowledge, this is the first study aiming to evaluate the capacity of liming and NT to mitigate the $\mathrm{N}_{2} \mathrm{O}$ emission after soil rewetting together with the expression of functional genes involved in $\mathrm{N}_{2} \mathrm{O}$ production (nirK, nirS, AOA-amoA, AOB-amoA) and consumption (nosZ) and the diversity of microbial communities bearing these functional genes. Liming application reduced the cumulative $\mathrm{N}_{2} \mathrm{O}$ emission by more than 70 and $65 \%$ respect to the unamended soil after soil re-wetting to $50 \%$ and $100 \%$ of FC, respectively. These findings demonstrate the usefulness of liming as a strategy to mitigate the $\mathrm{N}_{2} \mathrm{O}$ emission after the summer rains in Mediterranean areas. We found high impact of liming on the size, structure and transcription of 
selected microbial communities involved the $\mathrm{N}$ cycle and $\mathrm{N}_{2} \mathrm{O}$ emissions. The high transcription rate of nirK-bearing microbes and the absence of nitrifier transcription during the $\mathrm{N}_{2} \mathrm{O}$ peak could suggest that the $\mathrm{N}_{2} \mathrm{O}$ emission were caused by denitrification rather than nitrification. In addition, the strong stimulation of nirK gene transcription by liming suggests that the mechanism by which liming suppress the $\mathrm{N}_{2} \mathrm{O}$ emission was related with changes in the denitrification process and possibly with a higher or more efficient reduction of $\mathrm{N}_{2} \mathrm{O}$ to $\mathrm{N}_{2}$. However, further studies combining the gene expression quantification and ${ }^{15} \mathrm{~N}$ techniques are required to confirm this hypothesis. However, unlike expected, tillage practice did not affect the $\mathrm{N}_{2} \mathrm{O}$ emissions during the incubation experiment, which could be attributed to the disruption of soil structure by soil homogenization prior soil incubation. Therefore, in situ evaluation of gene transcription during a rewetting event would be necessary to confirm the obtained results and asses correctly the role of tillage practices in the process.

\subsection{Experiment 4: Effects of NT and liming on carbon and nitrogen mineralization}

During the ten years of the experiment, the combination of both NT and liming resulted in the increase of $\mathrm{C}$ contents, the amelioration of soil acidity, the increase of soil nutrients and the enhancement of microbial activity Using SEM we analyzed the trade-offs between both practices with three main implications: (i) the absence of relevant effects of Amendment on $\mathrm{C}$ mineralization could indicate that there is no $\mathrm{C}$ depletion risk; (ii) the greater influence of Amendment in the NNM than in C mineralization could be interpreted as a decoupling between the $\mathrm{C}$ and $\mathrm{N}$ mineralization which may enhance the $\mathrm{N}$ availability for crops or increase the risk of $\mathrm{N}$ losses during the fallow period; (iii) biological parameters, specifically the microbial biomass pool, are key indicators of management-induced changes in $\mathrm{C}$ cycling. In conclusion, we highlighted the usefulness of SEM technique to analyze the interactions and trade-offs between different agricultural practices in the soil $\mathrm{C}$ and $\mathrm{N}$ mineralization which is essential for the evaluation of possible benefits and drawbacks of management practices.

\subsection{Experiment 5: Effect of NT, liming and depth on soil proteases}

While NT practices predominantly influenced C-related enzyme, the main effects of liming were observed with regard to $\mathrm{N}$ cycling. We have strong indications that depolymerization of large proteins was triggered by liming, but mineralization to $\mathrm{NH}_{4}{ }^{+}$ 
was limited, probably because of plant and microbial uptake of monomers and amino acids, but a higher $\mathrm{N}$ leaching rate cannot be ruled out. Synergies between NT and liming practices were generally not observed, suggesting a decoupling between the $\mathrm{C}$ and $\mathrm{N}$ cycles in this semi-arid Mediterranean agro-ecosystem. However, further studies are required, probably using molecular approaches along with stable isotopes techniques to improve the understanding of soil $\mathrm{N}$ transformation and transport processes, especially with regard to the proteolytic activity and the fate of depolymerized $\mathrm{N}$ in Mediterranean agroecosystems as affected by widely used agronomic practices.

\subsection{Experiment 6: Effect of NT and liming on plant mycorrhization}

Liming raised the soil $\mathrm{pH}$, increased the $\mathrm{Ca}$ and $\mathrm{Mg}$ availability in soil and stimulated the microbial activity observed as DHase activity. On the other hand, NT increased the contents of $\mathrm{C}$ and $\mathrm{N}$ in soil. The oat plant biomass was increased by NT and liming while vetch biomass was only increased by liming throughout the whole growing season. The alleviation of soil acidity, the increase of nutrients by liming or the lower waterlogging conditions during the winter in NT as previously described (GómezPaccard et al. 2013, 2015)) could explain the higher plant growth. Similarly, the oat N content was increased by liming and NT while N vetch content only by liming. The stimulation of microbial activity by liming, linked with the higher substrate availability in NT could promote a higher $\mathrm{N}$ mineralization and $\mathrm{N}$ acquisition by crops. Furthermore, liming could have increased the $\mathrm{N}_{2}$ fixation by vetch which is sensitive to soil acidity.

In addition, AMF root colonization of both crops was higher under NT and in limed plots, despite of the relatively high content of available P in all treatments. Such an increase of root colonization could be caused by the absence of soil disturbance by tillage which avoided the disruption of fragile AMF mycelia and caused an increase of AMF propagules. In addition, the amelioration of soil acidity could have caused the improvement of plant growth and, consecutively, higher photosynthetic activity required for $\mathrm{C}$ allocation to the fungal partner. The higher AMF could contribute to the increase of plant biomass and the $\mathrm{N}$ content of crops by mean of several mechanism: (i) higher acquisition of $\mathrm{N}$ in form of $\mathrm{NH}_{4}{ }^{+}$with relatively low mobility in soil, (ii) higher availability of inorganic $\mathrm{N}$ derived from the higher SOM mineralization in the presence of AMF, (iii) the positive effect of AMF in the tripartite symbiosis between AMF, rhizobium and vetch which could increase the $\mathrm{N}_{2}$ fixation, or (iv) enhancing the transfer 
to the non-legume crop of the $\mathrm{N}_{2}$ fixed by legume. In addition, the positive effect of NT on $\mathrm{N}$ content in oat could be caused by higher AMF root colonization in the first sampling which could reduce the $\mathrm{Al}^{3+}$ toxicity of the non-amended treatments and enhance the $\mathrm{N}$ uptake under such conditions.

Altogether, the combination of NT and liming increased the crop growth and N content via changes in soil properties and their strong enhancement of AMF root colonization. In addition, the highest $\mathrm{N}$ and $\mathrm{P}$ uptake was also observed in limed NT plots, which indicates that the combination of these two common agronomic practices is a promising strategy to increase the yields and fertilizers efficiency in acid soils under Mediterranean conditions.

\subsection{Final conclusions}

The main conclusions of the present thesis could be summarized as:

C1: The combination of NT and liming increased the microbial activity and microbial populations in a degraded soil under Mediterranean conditions. However, the impact of both practices was mainly limited to the topsoil layer.

C2: The seasonality of the Mediterranean climate interacted with the agronomic practices affecting some microbial parameters. The amelioration of drought and heat in NT sustained higher microbial biomass and EAs during the summer period. This could be interpreted as an increase of soil microbial resilience to drought stress.

C3: The effect of tillage was mainly related with those microbial parameters related with $\mathrm{C}$-cycle, while liming affected mostly the $\mathrm{N}$-cycle. This could be interpreted as a decoupling between $\mathrm{C}$ and $\mathrm{N}$ cycle and could cause higher $\mathrm{N}$ losses and/or increase the $\mathrm{N}$ availability for crops.

C4: The stimulation of gross $\mathrm{N}$ transformation rates by liming during the summer fallow suggests higher $\mathrm{N}$ losses after soil rewetting. However, the impact of liming on $\mathrm{N}_{2} \mathrm{O}$ emissions after rewetting mitigated the $\mathrm{N}_{2} \mathrm{O}$ emissions in lime plots when compared to control.

C5: The combination of both practices increased synergistically the crop yield and the uptake of $\mathrm{N}$ and $\mathrm{P}$ at harvest. Liming and NT increased the root AMF-colonization which could be related with the higher crop yields or the increase of $\mathrm{N}$ acquisition by plants. 
C6: The combination of NT and liming had numerous and significant effects on soil microbial indicators and the $\mathrm{C}$ and $\mathrm{N}$ cycles, which highlights the need for a deep and detailed evaluation of the impact caused by agronomic practices in soil in order to assess their agronomic and environment suitability.

\subsection{Conclusiones finales}

Las principales conclusiones de esta tesis se podrían sintetizar como:

C1: La combinación del no-laboreo (NL) y la enmienda caliza incrementaron la actividad y las poblaciones microbianas en un suelo ácido degradado bajo condiciones Mediterráneas. Sin embargo, el impacto de ambas prácticas se limitó principalmente a la capa superior del suelo.

C2: La estacionalidad del clima Mediterráneo interactuó con las prácticas agronómicas afectando algunos de los parámetros microbiales estudiados. El alivio de las condiciones de sequía y calor en NL mantuvo una mayor biomasa microbiana y actividad enzimática durante el periodo estival. Esto se podría interpretar como un incremento de la resiliencia de los microorganismos del suelo al estrés por sequía.

C3: El efecto del NL estuvo principalmente relacionado con aquellos parámetros relacionados con el ciclo del $\mathrm{C}$, mientras que la enmienda caliza afectó principalmente el ciclo del N. Esto podría interpretarse como un desacople el ciclo del C y el N y podría causar mayores pérdidas de $\mathrm{N}$ y/o mayor disponibilidad de $\mathrm{N}$ mineral para los cultivos.

C4: La estimulación de las transformaciones brutas de $\mathrm{N}$ por la enmienda caliza durante el barbecho estival sugieren mayores pérdidas de $\mathrm{N}$ tras el rehumedecimiento. Sin embargo, el impacto de la enmienda sobre las emisiones de $\mathrm{N}_{2} \mathrm{O}$ tras rehumedecimiento mitigó las emisiones respecto los tratamientos sin enmendar.

C5: La combinación de NL y la enmienda caliza incrementó de forma sinérgica el rendimiento de los cultivos y la toma de $\mathrm{N}$ y $\mathrm{P}$ en la cosecha. El NL y la enmienda incrementaron la colonización micorrícica de las raíces, lo cual podría estar relacionado con el mayor rendimiento de los cultivos o la adquisición de $\mathrm{N}$ por las plantas.

C6: La combinación del NL y la enmienda caliza tuvo numerosos y significativos efectos en los indicadores microbiológicos estudiados y el ciclo del $\mathrm{C}$ y el $\mathrm{N}$, lo cual pone de manifiesto la necesidad una evaluación en profundidad y detallada del impacto 
CONCLUSIONS

causado por las prácticas agrícolas en el suelo con el fin de poder valorar su adecuación agronómica y ambiental. 


\section{REFERENCES}

Acosta-Martinez V, Acosta-Mercado D, Sotomayor-Ramírez D, Cruz-Rodríguez L (2008) Microbial communities and enzymatic activities under different management in semiarid soils. Appl Soil Ecol 38:249-260. doi: 10.1016/j.apsoil.2007.10.012

Acosta-Martínez V, Cotton J, Gardner T, et al (2014) Predominant bacterial and fungal assemblages in agricultural soils during a record drought/heat wave and linkages to enzyme activities of biogeochemical cycling. Appl Soil Ecol 84:69-82. doi: 10.1016/j.apsoil.2014.06.005

Acosta-Martinez V, Moore-Kucera J, Cotton J, et al (2014) Soil enzyme activities during the 2011 Texas record drought / heat wave and implications to biogeochemical cycling and organic matter dynamics §. Appl Soil Ecol 75:43-51. doi: 10.1016/j.apsoil.2013.10.008

Acosta-Martínez V, Tabatabai MA (2000) Enzyme activities in a limed agricultural soil. Biol Fertil Soils 31:85-91

Aguilera E, Lassaletta L, Gattinger A, Gimeno BS (2013) Managing soil carbon for climate change mitigation and adaptation in Mediterranean cropping systems: A meta-analysis. Agric Ecosyst Environ 168:25-36. doi: 10.1016/j.agee.2013.02.003

Allen SC, Nair VD, Graetz DA, et al (2006) Phosphorus loss from organic versus inorganic fertilizers used in alleycropping on a Florida Ultisol. Agric Ecosyst Environ. doi: 10.1016/j.agee.2006.04.010

Almagro M, Lopéz J, Querejeta JI, Martínez-Mena M (2009) Temperature dependence of soil $\mathrm{CO} 2$ efflux is strongly modulated by seasonal patterns of moisture availability in a ... Soil Biol Biochem 41:594-605. doi: 10.1016/j.soilbio.2008.12.021

Álvaro-Fuentes J, Lampurlanés J, Cantero-Martínez C (2009) Alternative crop rotations under Mediterranean no-tillage conditions: Biomass, grain yield, and water-use efficiency. Agron J 101:1227-1233. doi: 10.2134/agronj2009.0077

Alvaro-Fuentes J, Plaza-Bonilla D, Arrue JL, et al (2014) Soil organic carbon storage in a no-tillage chronosequence under Mediterranean conditions. Plant Soil 376:3141. doi: 10.1007/s11104-012-1167-x

Alvear M, Rosas A, Rouanet JL, Borie F (2005) Effects of three soil tillage systems on some biological activities in an Ultisol from southern Chile. Soil Tillage Res 82:195-202. doi: 10.1016/j.still.2004.06.002

Arregui LM, Quemada M (2006) Drainage and nitrate leaching in a crop rotation under different $\mathrm{N}$-fertilizer strategies: Application of capacitance probes. Plant Soil 288:57-69. doi: 10.1007/s11104-006-9064-9

Auler AC, Pires LF, dos Santos JAB, et al (2017) Effects of surface-applied and soilincorporated lime on some physical attributes of a Dystrudept soil. Soil Use Manag. doi: 10.1111/sum.12330

Aye NS, Sale PWG, Tang C (2016) The impact of long-term liming on soil organic carbon and aggregate stability in low-input acid soils. Biol Fertil Soils 52:697-709. doi: 10.1007/s00374-016-1111-y 
Bach H-J, Munch JC (2000) Identification of bacterial sources of soil peptidases. Biol Fertil Soils 31:224-291. doi: 10.1007/s003740050648

Badalucco L, Kuikman PJ, Nannipieri P (1996) Protease and deaminase activities in wheat rhizosphere and their relation to bacterial and protozoan populations. Biol Fertil Soils 23:99-104. doi: 10.1007/s003740050144

Banning NC, Maccarone LD, Fisk LM, Murphy D V (2015) Ammonia-oxidising bacteria not archaea dominate nitrification activity in semi-arid agricultural soil. Sci Rep 5:11146. doi: 10.1038/srep11146

Baraniya D, Puglisi E, Ceccherini MT, et al (2016) Protease encoding microbial communities and protease activity of the rhizosphere and bulk soils of two maize lines with different $\mathrm{N}$ uptake efficiency. Soil Biol Biochem 96:176-179. doi: 10.1016/j.soilbio.2016.02.001

Barea JM, Werner D, Azcón-Guilar C, Azcón R (2006) Interactions of Arbuscular Mycorrhiza and Nitrogen-Fixing Symbiosis in Sustainable Agriculture. In: Nitrogen Fixation in Agriculture, Forestry, Ecology, and the Environment

Bárta J, Melichová T, Vaněk D, et al (2010) Effect of $\mathrm{pH}$ and dissolved organic matter on the abundance of nirK and nirS denitrifiers in spruce forest soil. Biogeochemistry 101:123-132. doi: 10.1007/s10533-010-9430-9

Barton L, Butterbach-Bahl K, Kiese R, Murphy D V. (2011) Nitrous oxide fluxes from a grain-legume crop (narrow-leafed lupin) grown in a semiarid climate. Glob Chang Biol 17:1153-1166. doi: 10.1111/j.1365-2486.2010.02260.x

Barton L, Gleeson DB, Maccarone LD, et al (2013a) Is liming soil a strategy for mitigating nitrous oxide emissions from semi-arid soils? Soil Biol Biochem 62:2835. doi: 10.1016/j.soilbio.2013.02.014

Barton L, Kiese R, Gatter D, et al (2008) Nitrous oxide emissions from a cropped soil in a semi-arid climate. Glob Chang Biol 14:177-192. doi: 10.1111/j.13652486.2007.01474.x

Barton L, Murphy D V, Butterbach-Bahl K (2013b) Influence of crop rotation and liming on greenhouse gas emissions from a semi-arid soil. Agric Ecosyst Environ 167:23-32. doi: 10.1016/j.agee.2013.01.003

Barton L, Thamo T, Engelbrecht D, Biswas WK (2014) Does growing grain legumes or applying lime cost effectively lower greenhouse gas emissions from wheat production in a semi-arid climate? J Clean Prod. doi: 10.1016/j.jclepro.2014.07.020

Batjes NH (2014) Total carbon and nitrogen in the soils of the world. Eur J Soil Sci. doi: 10.1111/ejss.12114_2

Batlle-bayer L, Batjes NH, Bindraban PS (2010) Agriculture , Ecosystems and Environment Changes in organic carbon stocks upon land use conversion in the Brazilian Cerrado : A review. 137:47-58. doi: 10.1016/j.agee.2010.02.003

Bausenwein U, Gattinger A, Langer U, et al (2008) Exploring soil microbial communities and soil organic matter: Variability and interactions in arable soils under minimum tillage practice. Appl Soil Ecol 40:67-77. doi: 10.1016/j.apsoil.2008.03.006

Beare MH, Hu S, Coleman DC, Hendrix PF (1997) Influences of mycelial fungi on soil 
aggregation and organic matter storage in conventional and no-tillage soils. Appl Soil Ecol. doi: 10.1016/S0929-1393(96)00142-4

Beggi F, Hamidou F, Hash CT, Buerkert A (2016) Effects of early mycorrhization and colonized root length on low-soil-phosphorus resistance of West African pearl millet. J Plant Nutr Soil Sci 179:466-471. doi: 10.1002/jpln.201500501

Bérard A, Bouchet T, Sévenier G, et al (2011) Resilience of soil microbial communities impacted by severe drought and high temperature in the context of Mediterranean heat waves. Eur J Soil Biol 47:333-342. doi: 10.1016/j.ejsobi.2011.08.004

Bescansa P, Imaz MJ, Virto I, et al (2006) Soil water retention as affected by tillage and residue management in semiarid Spain. Soil Tillage Res 87:19-27. doi: 10.1016/j.still.2005.02.028

Bollmann A, Bär-Gilissen MJ, Laanbroek HJ (2002) Growth at low ammonium concentrations and starvation response as potential factors involved in niche differentiation among ammonia-oxidizing bacteria. Appl Environ Microbiol 68:4751-4757. doi: 10.1128/AEM.68.10.4751-4757.2002

Booth MS, Stark JM, Rastetter E (2005) Controls on nitrogen cycling in terrestrial ecosystems: a synthetic analysis of literature data. Ecol Monogr 75:139-157

Borie F, Rubio R (1999) Effects of arbuscular mycorrhizae and liming on growth and mineral acquisition of aluminum-tolerant and aluminum-sensitive barley cultivars. J Plant Nutr 22:121-137. doi: 10.1080/01904169909365612

Borie F, Rubio R, Rouanet JL, et al (2006) Effects of tillage systems on soil characteristics, glomalin and mycorrhizal propagules in a Chilean Ultisol. Soil Tillage Res 88:253-261. doi: 10.1016/j.still.2005.06.004

Borken W, Matzner E (2009) Reappraisal of drying and wetting effects on C and N mineralization and fluxes in soils. Glob Chang Biol 15:808-824. doi: 10.1111/j.1365-2486.2008.01681.x

Boyle SA, Yarwood RR, Bottomley PJ, Myrold DD (2008) Bacterial and fungal contributions to soil nitrogen cycling under Douglas fir and red alder at two sites in Oregon. Soil Biol Biochem 40:443-451. doi: 10.1016/j.soilbio.2007.09.007

Bremner JM, Mulvaney CS (1982) Nitrogen-Total. In: Page AL, Miller, R H, D.R. K (eds) Methods of Soil Analysis. Part 2. Chemical and Microbiological Properties (Agronomy series n 9) ASA. SSSA Madison, Wisconsin, pp 595-624

Brenzinger K, Dörsch P, Braker G (2015) pH-driven shifts in overall and transcriptionally active denitrifiers control gaseous product stoichiometry in growth experiments with extracted bacteria from soil. Front Microbiol 6:1-11. doi: 10.3389/fmicb.2015.00961

Brito I, Goss MJ, De Carvalho M (2012) Effect of tillage and crop on arbuscular mycorrhiza colonization of winter wheat and triticale under Mediterranean conditions. Soil Use Manag 28:202-208. doi: 10.1111/j.1475-2743.2012.00404.x

Brookes PC, Landman A, Pruden G, Jenkinson DS (1985) Chloroform fumigation and the release of soil nitrogen: A rapid direct extraction method to measure microbial biomass nitrogen in soil. Soil Biol Biochem 17:837-842. doi: 10.1016/00380717(85)90144-0

Brunel-Saldias N, Seguel O, Ovalle C, et al (2018) Tillage effects on the soil water 
balance and the use of water by oats and wheat in a Mediterranean climate. Soil Tillage Res 184:68-77. doi: 10.1016/j.still.2018.07.005

Brussaard L, Pulleman MM, Ouédraogo É, et al (2007) Soil fauna and soil function in the fabric of the food web. Pedobiologia (Jena) 50:447-462. doi: 10.1016/j.pedobi.2006.10.007

Butterbach-Bahl K, Baggs EM, Dannenmann M, et al (2013) Nitrous oxide emissions from soils: how well do we understand the processes and their controls? Philos Trans R Soc Lond B Biol Sci 368:20130122. doi: 10.1098/rstb.2013.0122

Caires EF, Alleoni LRF, Cambri MA, Barth G (2005) Surface Application of Lime for Crop Grain Production Under a No-Till System Surface Application of Lime for Crop Grain Production Under a No-Till System. Agron J 97:791-798. doi: 10.2134/agronj2004.0207

Caires EF, Barth G, Garbuio FJ (2006) Lime application in the establishment of a no-till system for grain crop production in Southern Brazil. Soil Tillage Res 89:3-12. doi: 10.1016/j.still.2005.06.006

Caires EF, Garbuio FJ, Churka S, et al (2008) Effects of soil acidity amelioration by surface liming on no-till corn, soybean, and wheat root growth and yield. Eur J Agron 28:57-64. doi: 10.1016/j.eja.2007.05.002

Caires EF, Joris HAW, Churka S (2011) Long-term effects of lime and gypsum additions on no-till corn and soybean yield and soil chemical properties in southern Brazil. Soil Use Manag. doi: 10.1111/j.1475-2743.2010.00310.x

Cambardella CA, Elliott ET (1992) Particulate Soil Organic-Matter Changes across a Grassland Cultivation Sequence. Soil Sci Soc Am J 56:777. doi: 10.2136/sssaj1992.03615995005600030017x

Cantero-Martínez C, Angás P, Lampurlanés J (2007) Long-term yield and water use efficiency under various tillage systems in Mediterranean rainfed conditions. Ann Appl Biol 150:293-305. doi: 10.1111/j.1744-7348.2007.00142.x

Cao C, Jiang D, Teng X, et al (2008) Soil chemical and microbiological properties along a chronosequence of Caragana microphylla Lam. plantations in the Horqin sandy land of Northeast China. Appl Soil Ecol 40:78-85. doi: 10.1016/j.apsoil.2008.03.008

Carbonell-Bojollo R, González-Sánchez EJ, Veróz-González O, Ordóñez-Fernández R (2011) Soil management systems and short term CO2 emissions in a clayey soil in southern Spain. Sci Total Environ 409:2929-2935. doi: 10.1016/j.scitotenv.2011.04.003

Carmeis Filho ACA, Penn CJ, Crusciol CAC, Calonego JC (2017) Lime and phosphogypsum impacts on soil organic matter pools in a tropical Oxisol under long-term no-till conditions. Agric Ecosyst Environ 241:11-23. doi: 10.1016/j.agee.2017.02.027

Castellanos-Navarrete A, Rodríguez-Aragonés C, De Goede RGM, et al (2012) Earthworm activity and soil structural changes under conservation agriculture in central Mexico. Soil Tillage Res. doi: 10.1016/j.still.2012.03.011

Chatterjee A, Lal R (2009) On farm assessment of tillage impact on soil carbon and associated soil quality parameters. Soil Tillage Res. doi: 10.1016/j.still.2009.03.006 
Chen X, Zhang L-M, Shen J-P, et al (2011) Abundance and community structure of ammonia-oxidizing archaea and bacteria in an acid paddy soil. Biol Fertil Soils 47:323-331. doi: 10.1007/s00374-011-0542-8

Cheng Y, Wang J, Wang S-Q, et al (2014) Effects of soil moisture on gross N transformations and $\mathrm{N} 2 \mathrm{O}$ emission in acid subtropical forest soils. Biol Fertil Soils 50:1099-1108. doi: 10.1007/s00374-014-0930-y

Colman BP, Schimel JP (2013) Drivers of microbial respiration and net $\mathrm{N}$ mineralization at the continental scale. Soil Biol Biochem 60:65-76. doi: 10.1016/j.soilbio.2013.01.003

Conant RT, Easter M, Paustian K, et al (2007) Impacts of periodic tillage on soil C stocks: A synthesis. Soil Tillage Res.

Conyers MK, Heenan DP, Mcghie WJ, Poile GP (2003) Amelioration of acidity with time by limestone under contrasting tillage. 72:85-94. doi: 10.1016/S01671987(03)00064-3

Cookson WR, Marschner P, Clark IM, et al (2006) The influence of season, agricultural management, and soil properties on gross nitrogen transformations and bacterial community structure. Aust J Soil Res 44:453-465. doi: 10.1071/SR05042

Cookson WR, Murphy D V., Roper MM (2008) Characterizing the relationships between soil organic matter components and microbial function and composition along a tillage disturbance gradient. Soil Biol Biochem 40:763-777. doi: 10.1016/j.soilbio.2007.10.011

Cookson WR, Osman M, Marschner P, et al (2007) Controls on soil nitrogen cycling and microbial community composition across land use and incubation temperature. Soil Biol Biochem 39:744-756. doi: 10.1016/j.soilbio.2006.09.022

Corre MD, Beese FO, Brumme R (2003) Soil Nitrogen Cycle in High Nitrogen Deposition Forest: Changes under Nitrogen Saturation and Liming. Ecol Appl 13:287-298. doi: 10.1890/1051-0761(2003)013[0287:SNCIHN]2.0.CO;2

Creamer RE, Schulte RPO, Stone D, et al (2014) Measuring basal soil respiration across Europe: Do incubation temperature and incubation period matter? Ecol Indic 36:409-418. doi: 10.1016/j.ecolind.2013.08.015

Crews TE, Peoples MB (2005) Can the synchrony of nitrogen supply and crop demand be improved in legume and fertilizer-based agroecosystems? A review. Nutr Cycl Agroecosystems 72:101-120. doi: 10.1007/s10705-004-6480-1

Crittenden SJ, de Goede RGM (2016) Integrating soil physical and biological properties in contrasting tillage systems in organic and conventional farming. Eur J Soil Biol. doi: 10.1016/j.ejsobi.2016.09.003

Crittenden SJ, Eswaramurthy T, de Goede RGM, et al (2014) Effect of tillage on earthworms over short- and medium-term in conventional and organic farming. Appl Soil Ecol. doi: 10.1016/j.apsoil.2014.03.001

Cruz-Paredes C, López-García Á, Rubæk GH, et al (2017) Risk assessment of replacing conventional $\mathrm{P}$ fertilizers with biomass ash: Residual effects on plant yield, nutrition, cadmium accumulation and mycorrhizal status. Sci Total Environ 575:1168-1176. doi: 10.1016/j.scitotenv.2016.09.194

Čuhel J, Šimek M, Laughlin RJ, et al (2010) Insights into the effect of soil pH on N2O 
and N2 emissions and denitrifier community size and activity. Appl Environ Microbiol 76:1870-1878. doi: 10.1128/AEM.02484-09

Culman SW, Snapp SS, Freeman MA, et al (2012) Permanganate Oxidizable Carbon Reflects a Processed Soil Fraction that is Sensitive to Management. Soil Sci Soc Am J 76:494. doi: 10.2136/sssaj2011.0286

Dahiya R, Dahiya R, Ingwersen J, Streck T (2007) The effect of mulching and tillage on the water and temperature regimes of a loess soil: Experimental findings and modeling The effect of mulching and tillage on the water and temperature. doi: 10.1016/j.still.2007.02.004

Dai J, Hu J, Zhu A, et al (2015) No tillage enhances arbuscular mycorrhizal fungal population, glomalin-related soil protein content, and organic carbon accumulation in soil macroaggregates. J Soils Sediments 15:1055-1062. doi: 10.1007/s11368015-1091-9

Dandie CE, Wertz S, Leclair CL, et al (2011) Abundance, diversity and functional gene expression of denitrifier communities inadjacent riparian and agricultural zones. FEMS Microbiol Ecol 77:69-82. doi: 10.1111/j.1574-6941.2011.01084.x

Dannenmann M, Gasche R, Ledebuhr A, Papen H (2006) Effects of forest management on soil N cycling in beech forests stocking on calcareous soils. Plant Soil 279-300. doi: 10.1007/s11104-006-9077-4

Dannenmann M, Simon J, Gasche R, et al (2009) Tree girdling provides insight on the role of labile carbon in nitrogen partitioning between soil microorganisms and adult European beech. Soil Biol Biochem 41:1622-1631. doi: 10.1016/j.soilbio.2009.04.024

Das Kumar Shonkor VA (2011) Role of enzymes in maintaining soil health. In: Soil Enzymology, Soil Biology

Davidson E, Stark J, Firestone M (1990) Microbial Production and Consumpution of Nitrate in an Annual Grassland. Ecology 71:1968-1975. doi: 10.2307/1937605

Davidson EA, Hart SC, Shanks CA, Firestone MK (1991) Measuring gross nitrogen mineralization, and nitrification by $15 \mathrm{~N}$ isotopic pool dilution in intact soil cores. $\mathrm{J}$ Soil Sci 42:335-349. doi: 10.1111/j.1365-2389.1991.tb00413.x

Deng J, Guo L, Salas W, et al (2018) Changes in Irrigation Practices Likely Mitigate Nitrous Oxide Emissions From California Cropland. Global Biogeochem Cycles. doi: 10.1029/2018GB005961

Di HJ, Cameron KC, Shen J-P, et al (2010) Ammonia-oxidizing bacteria and archaea grow under contrasting soil nitrogen conditions. FEMS Microbiol Ecol 72:386-94. doi: 10.1111/j.1574-6941.2010.00861.x

Díaz-Pinés E, Molina-Herrera S, Dannenmann M, et al (2017) Nitrate leaching and soil nitrous oxide emissions diminish with time in a hybrid poplar short-rotation coppice in southern Germany. GCB Bioenergy. doi: 10.1111/gcbb.12367

Dong W, Hu C, Zhang Y, Wu D (2012) Gross mineralization, nitrification and N2O emission under different tillage in the North China Plain. Nutr Cycl Agroecosystems 94:237-247. doi: 10.1007/s10705-012-9536-7

Eaton JM, McGoff NM, Byrne KA, et al (2008) Land cover change and soil organic carbon stocks in the Republic of Ireland 1851-2000. Clim Change. doi: 


\section{$10.1007 / \mathrm{s} 10584-008-9412-2$}

Eisenhauer N, Bowker MA, Grace JB, Powell JR (2015) From patterns to causal understanding: Structural equation modeling (SEM) in soil ecology. Pedobiologia (Jena) 58:65-72. doi: 10.1016/j.pedobi.2015.03.002

Ekenler M, Tabatabai MA (2003) Effects of liming and tillage systems on microbial biomass and glycosidases in soils. Biol Fertil Soils. doi: 10.1007/s00374-0030664-8

Espejo R (1987) The soils and ages of the "raña" surfaces related to the Villuercas and Altamira mountain ranges (Western Spain). Catena 14:399-418. doi: 10.1016/0341-8162(87)90012-9

Espejo Serrano R (1985) The ages and soils of two levels of "raña" surfaces in Central Spain. Geoderma. doi: 10.1016/0016-7061(85)90039-4

Evans SE, Burke IC (2013) Carbon and Nitrogen Decoupling Under an 11-Year Drought in the Shortgrass Steppe. Ecosystems 16:20-33. doi: 10.1007/s10021-0129593-4

Fabrizzi KP, García FO, Costa JL, Picone LI (2005) Soil water dynamics, physical properties and corn and wheat responses to minimum and no-tillage systems in the responses to minimum and no-tillage systems in. Soil Tillage Res 81:57-69. doi: 10.1016/j.still.2004.05.001

Fageria NK, Baligar VC (2008) Chapter 7 Ameliorating Soil Acidity of Tropical Oxisols by Liming For Sustainable Crop Production. Adv. Agron.

Fanin N, Bertrand I (2016) Aboveground litter quality is a better predictor than belowground microbial communities when estimating carbon mineralization along a land-use gradient. Soil Biol Biochem 94:48-60. doi: 10.1016/j.soilbio.2015.11.007

Feng K, Yan F, Hütsch BW, Schubert S (2003) Nitrous oxide emission as affected by liming an acidic mineral soil used for arable agriculture. Nutr Cycl Agroecosystems 67:283-292. doi: 10.1023/B:FRES.0000003664.51048.0e

Fisk LM, Barton L, Jones DL, et al (2015a) Root exudate carbon mitigates nitrogen loss in a semi-arid soil. Soil Biol Biochem 88:380-389. doi: 10.1016/j.soilbio.2015.06.011

Fisk LM, Maccarone LD, Barton L, Murphy D V. (2015b) Nitrapyrin decreased nitrification of nitrogen released from soil organic matter but not amoA gene abundance at high soil temperature. Soil Biol Biochem. doi: 10.1016/j.soilbio.2015.05.029

Forster JC (1995) Soil Nitrogen. In: Alef K NP (ed) Methods in Applied Soil Microbiology and Biochemistry. pp 79-87

Francis CA, Roberts KJ, Beman JM, et al (2005) Ubiquity and diversity of ammoniaoxidizing archaea in water columns and sediments of the ocean. Proc Natl Acad Sci 102:14683-14688. doi: 10.1073/pnas.0506625102

Franco-Andreu L, Gómez I, Parrado J, et al (2017) Soil Biology Changes as a Consequence of Organic Amendments Subjected to a Severe Drought. L Degrad Dev. doi: 10.1002/ldr.2663

Franzluebbers AJ (2002) Soil organic matter stratification ratio as an indicator of soil 
quality. Soil Tillage Res. doi: 10.1016/S0167-1987(02)00018-1

Franzluebbers AJ (2010) Achieving Soil Organic Carbon Sequestration with Conservation Agricultural Systems in the Southeastern United States. Soil Sci Soc Am J. doi: 10.2136/sssaj2009.0079

Fuka MM, Engel M, Gattinger A, et al (2008) Factors influencing variability of proteolytic genes and activities in arable soils. Soil Biol Biochem 40:1646-1653. doi: 10.1016/j.soilbio.2008.01.028

Gál A, Vyn TJ, Michéli E, et al (2007) Soil carbon and nitrogen accumulation with long-term no-till versus moldboard plowing overestimated with tilled-zone sampling depths. Soil Tillage Res 96:42-51. doi: 10.1016/j.still.2007.02.007

García-Gil JC, Plaza C, Senesi N, et al (2004) Effects of sewage sludge amendment on humic acids and microbiological properties of a semiarid Mediterranean soil. Biol Fertil Soils 39:320-328. doi: 10.1007/s00374-003-0709-z

García-González I, Quemada M, Gabriel JL, Hontoria C (2016) Arbuscular mycorrhizal fungal activity responses to winter cover crops in a sunflower and maize cropping system. Appl Soil Ecol 102:10-18. doi: 10.1016/j.apsoil.2016.02.006

García-Marco S, Abalos D, Espejo R, et al (2016) No tillage and liming reduce greenhouse gas emissions from poorly drained agricultural soils in Mediterranean regions. Sci Total Environ 566-567:512-520. doi: 10.1016/j.scitotenv.2016.05.117

García C, Hernández T, Costa F, et al (1993) Hydrolases in the organic matter fractions of sewage sludge: Changes with composting. Bioresour Technol 45:47-52. doi: 10.1016/0960-8524(93)90142-X

Geisseler D, Georg R, Ludwig B (2012) Pedobiologia - International Journal of Soil Biology Potential soil enzyme activities are decoupled from microbial activity in dry residue-amended soil. Pedobiologia - Int J Soil Biol 55:253-261. doi: 10.1016/j.pedobi.2012.04.003

Geisseler D, Horwath WR (2008) Regulation of extracellular protease activity in soil in response to different sources and concentrations of nitrogen and carbon. Soil Biol Biochem 40:3040-3048. doi: 10.1016/j.soilbio.2008.09.001

Geisseler D, Horwath WR (2009) Relationship between carbon and nitrogen availability and extracellular enzyme activities in soil. Pedobiologia (Jena). doi: 10.1016/j.pedobi.2009.06.002

Gibbons JM, Williamson JC, Williams AP, et al (2014) Sustainable nutrient management at field, farm and regional level: Soil testing, nutrient budgets and the trade-off between lime application and greenhouse gas emissions. Agric Ecosyst Environ. doi: 10.1016/j.agee.2014.02.016

Giorgi F, Lionello P (2008) Climate change projections for the Mediterranean region. Glob Planet Change. doi: 10.1016/j.gloplacha.2007.09.005

Gispert M, Emran M, Pardini G, et al (2013) The impact of land management and abandonment on soil enzymatic activity, glomalin content and aggregate stability. Geoderma 202-203:51-61. doi: 10.1016/j.geoderma.2013.03.012

Godsey CB, Pierzynski GM, Mengel DB, Lamond RE (2010) Changes in Soil pH, Organic Carbon, and Extractable Aluminum from Crop Rotation and Tillage. Soil Sci Soc Am J 71:1038. doi: 10.2136/sssaj2006.0170 
Gómez-Paccard C, Hontoria C, Mariscal-Sancho I, et al (2015) Soil-water relationships in the upper soil layer in a Mediterranean Palexerult as affected by no-tillage under excess water conditions - Influence on crop yield. Soil Tillage Res 146:303-312. doi: 10.1016/j.still.2014.09.012

Gómez-Paccard C, Mariscal-Sancho I, León P, et al (2013) Ca-amendment and tillage: Medium term synergies for improving key soil properties of acid soils. Soil Tillage Res. doi: 10.1016/j.still.2013.08.009

Gómez-Rey MX, Couto-Vázquez A， González-Prieto SJ (2012) Nitrogen transformation rates and nutrient availability under conventional plough and conservation tillage. Soil Tillage Res 124:144-152. doi: 10.1016/j.still.2012.05.010

Gonzalez-Quiñones V, Stockdale EA, Banning NC, et al (2011) Soil microbial biomassInterpretation and consideration for soil monitoring. Soil Res. doi: 10.1071/SR10203

González-Sánchez EJ, Ordóñez-Fernández R, Carbonell-Bojollo R, et al (2012) Metaanalysis on atmospheric carbon capture in Spain through the use of conservation agriculture. Soil Tillage Res.

Gonzalez-Sanchez EJ, Veroz-Gonzalez O, Blanco-Roldan GL, et al (2015) A renewed view of conservation agriculture and its evolution over the last decade in Spain. Soil Tillage Res. doi: 10.1016/j.still.2014.10.016

Goulding KWT (2016) Soil acidification and the importance of liming agricultural soils with particular reference to the United Kingdom. Soil Use Manag.

Grover SP, Butterly CR, Wang X, Tang C (2017) The short-term effects of liming on organic carbon mineralisation in two acidic soils as affected by different rates and application depths of lime. 431-443. doi: 10.1007/s00374-017-1196-y

Guardia G, Tellez-Rio A, García-Marco S, et al (2016) Effect of tillage and crop (cereal versus legume) on greenhouse gas emissions and Global Warming Potential in a non-irrigated Mediterranean field. Agric Ecosyst Environ. doi: 10.1016/j.agee.2016.01.047

Guardia G, Vallejo A, Cardenas LM, et al (2018) Fate of 15N-labelled ammonium nitrate with or without the new nitrification inhibitor DMPSA in an irrigated maize crop. Soil Biol Biochem. doi: 10.1016/j.soilbio.2017.10.013

Guo F, Yost RS, Hue NV, et al (2000) Changes in Phosphorus Fractions in Soils under Intensive Plant Growth. Soil Sci Soc Am J. doi: 10.2136/sssaj2000.6451681x

Guo JH, Liu XJ, Zhang Y, et al (2010) Significant Acidification in Major Chinese Croplands. Science (80- ) 327:1008-1010. doi: 10.1126/science.1182570

Guo XB, Drury CF, Yang XM, et al (2014) The extent of soil drying and rewetting affects nitrous oxide emissions, denitrification, and nitrogen mineralization. Soil Sci Soc Am J 78:194-204. doi: 10.2136/sssaj2013.06.0219

Gütlein A, Dannenmann M, Kiese R (2016) Gross nitrogen turnover rates of a tropical lower montane forest soil : Impacts of sample preparation and storage. Soil Biol Biochem 95:8-10. doi: 10.1016/j.soilbio.2015.12.002

Gütlein A, Zistl-Schlingmann M, Becker JN, et al (2017) Nitrogen turnover and greenhouse gas emissions in a tropical alpine ecosystem, Mt. Kilimanjaro, 
Tanzania. Plant Soil 411:243-259. doi: 10.1007/s11104-016-3029-4

Halpern MT, Whalen JK, Madramootoo C a. (2010) Long-Term Tillage and Residue Management Influences Soil Carbon and Nitrogen Dynamics. Soil Sci Soc Am J 74:1211. doi: 10.2136/sssaj2009.0406

Hammer Ø, Harper D, Ryan P (2001) Past: Paleontological statistics software package for education and data analysis. Paleontol Electron

Harrison-Kirk T, Beare MH, Meenken ED, Condron LM (2013) Soil organic matter and texture affect responses to dry/wet cycles: Effects on carbon dioxide and nitrous oxide emissions. Soil Biol Biochem. doi: 10.1016/j.soilbio.2012.10.008

Hart SC, Stark JM, Davidson EA, Firestone MK (1994) Nitrogen mineralisation, immobilisation and nitrification. In: Methods of Soil Analysis: Microbiological and Biochemical Properties, Part 2, 3rd edn. ASA and SSSA, Madison, pp 9851013

Haynes RJ, Naidu R (1998) Influence of lime, fertilizer and manure applications on soil organic matter content and soil physical conditions: A review. Nutr 51:123-137. doi: $10.1023 / \mathrm{A}$

Haynes RJ, Swift RS (1988) Effects of lime and phosphate additions on changes in enzyme activities, microbial biomass and levels of extractable nitrogen, sulphur and phosphorus in an acid soil. Biol Fertil Soils 6:153-158. doi: 10.1007/BF00257666

He J, Li HW, Wang QJ, et al (2010) The adoption of conservation tillage in China. Ann N Y Acad Sci 1195:96-106. doi: 10.1111/j.1749-6632.2009.05402.x

He JZ, Hu HW, Zhang LM (2012) Current insights into the autotrophic thaumarchaeal ammonia oxidation in acidic soils. Soil Biol Biochem 55:146-154. doi: 10.1016/j.soilbio.2012.06.006

Heijboer A, ten Berge HFM, de Ruiter PC, et al (2016) Plant biomass, soil microbial community structure and nitrogen cycling under different organic amendment regimes; a15N tracer-based approach. Appl Soil Ecol 107:251-260. doi: 10.1016/j.apsoil.2016.06.009

Helgason BL, Walley FL, Germida JJ (2009) Fungal and bacterial abundance in longterm no-till and intensive-till soils of the Northern Great Plains. Soil Sci Soc Am J 73:120-127. doi: 10.2136/sssaj2007.0392

Henderson SL, Dandie CE, Patten CL, et al (2010) Changes in denitrifier abundance, denitrification gene mRNA levels, nitrous oxide emissions, and denitrification in anoxic soil microcosms amended with glucose and plant residues. Appl Environ Microbiol. doi: 10.1128/AEM.02993-09

Henry HAL (2012) Soil extracellular enzyme dynamics in a changing climate. Soil Biol Biochem 47:53-59. doi: 10.1016/j.soilbio.2011.12.026

Henry S, Baudoin E, López-Gutiérrez JC, et al (2004) Quantification of denitrifying bacteria in soils by nirK gene targeted real-time PCR. J Microbiol Methods. doi: 10.1016/j.mimet.2004.07.002

Henry S, Bru D, Stres B, et al (2006) Quantitative detection of the nosZ gene, encoding nitrous oxide reductase, and comparison of the abundances of $16 \mathrm{~S}$ rRNA, narG, nirK, and nosZ genes in soils. Appl Environ Microbiol. doi: 10.1128/AEM.00231- 
06

Herman DJ, Firestone MK, Nuccio E, Hodge A (2012) Interactions between an arbuscular mycorrhizal fungus and a soil microbial community mediating litter decomposition. FEMS Microbiol Ecol 80:236-247. doi: 10.1111/j.15746941.2011.01292.x

Hink L, Nicol GW, Prosser JI (2017) Archaea produce lower yields of N2O than bacteria during aerobic ammonia oxidation in soil. Environ Microbiol 19:48294837. doi: 10.1111/1462-2920.13282

Hinojosa MB, García-Ruíz R, Viñegla B, Carreira JA (2004) Microbiological rates and enzyme activities as indicators of functionality in soils affected by the Aznalcóllar toxic spill. Soil Biol Biochem 36:1637-1644. doi: 10.1016/j.soilbio.2004.07.006

Hoffmann GG, Dedeken M (1965) Eine Methode zur colorimetrischen Bestimmung der $\beta$-Glucosidase-Aktivität in Böden. Zeitschrift für Pflanzenernährung, Düngung, Bodenkd 108:193-198. doi: 10.1002/jpln.19651080302

Homyak PM, Allison SD, Huxman TE, et al (2018) Effects of Drought Manipulation on Soil Nitrogen Cycling: A Meta-Analysis. J Geophys Res Biogeosciences 2100:. doi: 10.1002/2017JG004146

Hontoria C, Gómez-Paccard C, Mariscal-Sancho I, et al (2016) Aggregate size distribution and associated organic $\mathrm{C}$ and $\mathrm{N}$ under different tillage systems and $\mathrm{Ca}-$ amendment in a degraded Ultisol. Soil Tillage Res 160:42-52. doi: 10.1016/j.still.2016.01.003

Hontoria C, Gómez-Paccard C, Vazquez E, et al (2018) Mid-long term effects of no tillage and Ca-amendment on degraded acid soils under contrasting weather conditions. Soil Tillage Res 183:83-92. doi: 10.1016/j.still.2017.08.011

Hoon C, Kyoung D, Aslam M, Joo P (2008) Effects of oyster shell on soil chemical and biological properties and cabbage productivity as a liming materials. Waste Manag 28:2702-2708. doi: 10.1016/j.wasman.2007.12.005

Hooper D, Coughlan J, Mullen M (2008) Structural equation modelling: Guidelines for determining model fit. Electronic Journal of Business Research Methods. Electron J Bus Res Methods 6:53-59. doi: 10.1037/1082-989X.12.1.58

Hou R, Ouyang Z, Maxim D, et al (2016) Lasting effect of soil warming on organic matter decomposition depends on tillage practices. Soil Biol Biochem 95:243-249. doi: 10.1016/j.soilbio.2015.12.008

Hoyle FC, Murphy D V., Fillery IRP (2006) Temperature and stubble management influence microbial $\mathrm{CO} 2-\mathrm{C}$ evolution and gross $\mathrm{N}$ transformation rates. Soil Biol Biochem 38:71-80. doi: 10.1016/j.soilbio.2005.04.020

Hueso S, García C, Hernández T (2012) Severe drought conditions modify the microbial community structure, size and activity in amended and unamended soils. Soil Biol Biochem 50:167-173. doi: 10.1016/j.soilbio.2012.03.026

Hueso S, Hernández T, García C (2011) Resistance and resilience of the soil microbial biomass to severe drought in semiarid soils: The importance of organic amendments. Appl Soil Ecol 50:27-36. doi: 10.1016/j.apsoil.2011.07.014

Hungria M, Vargas MAT (2000) Environmental factors affecting N2 fixation in grain legumes in the tropics with an emphasis on Brazil. 4290:151-164. doi: 


\section{$10.1016 / \mathrm{S} 0378-4290(99) 00084-2$}

Hurisso TT, Culman SW, Horwath WR, et al (2016) Comparison of PermanganateOxidizable Carbon and Mineralizable Carbon for Assessment of Organic Matter Stabilization and Mineralization. Soil Sci Soc Am J 80:1352. doi: 10.2136/sssaj2016.04.0106

Iannotti DA, Pang T, Toth BL, et al (1993) A Quantitative Respirometric Method for Monitoring Compost Stability. Compost Sci Util 1:52-65. doi: 10.1080/1065657X.1993.10757890

Inagaki TM, de Moraes Sá JC, Caires EF, Gonçalves DRP (2017) Why does carbon increase in highly weathered soil under no-till upon lime and gypsum use? Sci Total Environ 599-600:523-532. doi: 10.1016/j.scitotenv.2017.04.234

Inagaki TM, Sá JCDM, Caires EF, Gonçalves DRP (2016) Lime and gypsum application increases biological activity, carbon pools, and agronomic productivity in highly weathered soil. Agric Ecosyst Environ 231:156-165. doi: 10.1016/j.agee.2016.06.034

Insam H (2001) Developments in soil microbiology since the mid 1960s. Geoderma 100:389-402

Intergovernmental Panel on Climate Change (2014) Summary for policymakers. Clim Chang 2014 Mitig Clim Chang Contrib Work Gr III to Fifth Assess Rep Intergov Panel Clim Chang 1-31. doi: 10.1017/CBO9781107415416

Jalonen R, Nygren P, Sierra J (2009) Transfer of nitrogen from a tropical legume tree to an associated fodder grass via root exudation and common mycelial networks. Plant Cell Environ 32:1366-1376. doi: 10.1111/j.1365-3040.2009.02004.x

Joergensen RG (1996a) The fumigation-extraction method to estimate soil microbial biomass: Calibration of the kEC value. Soil Biol Biochem 28:25-31. doi: 10.1016/0038-0717(95)00102-6

Joergensen RG (1996b) The fumigation-extraction method to estimate soil microbial biomass: Calibration of the kEC value. Soil Biol Biochem 28:25-31. doi: 10.1016/0038-0717(95)00102-6

Johnson NC (2010) Resource stoichiometry elucidates the structure and function of arbuscular mycorrhizas across scales. New Phytol. 185:631-647

Jones RJA, Hiederer R, Rusco E, Montanarella L (2005) Estimating organic carbon in the soils of Europe for policy support. Eur J Soil Sci. doi: 10.1111/j.13652389.2005.00728.x

Joris HAW, Caires EF, Scharr DA, et al (2016) Liming in the conversion from degraded pastureland to a no-till cropping system in Southern Brazil. Soil Tillage Res 162:68-77. doi: 10.1016/j.still.2016.04.009

Kaiser K, Kalbitz K (2012) Cycling downwards - dissolved organic matter in soils. Soil Bio Biochem, 52, 29-32

Kandeler E, Gerber H (1988) Short-term assay of soil urease activity using colorimetric determination of ammonium. Biol Fertil Soils 6:. doi: 10.1007/BF00257924

Kandeler E, Stemmer M, Klimanek E-M (1999) Response of soil microbial biomass, urease and xylanase within particle size fractions to long-term soil management. Soil Biol Biochem 31:261-273. doi: 10.1016/S0038-0717(98)00115-1 
Karwat H, Moreta D, Arango J, et al (2017) Residual effect of BNI by Brachiaria humidicola pasture on nitrogen recovery and grain yield of subsequent maize. Plant Soil 1-18. doi: 10.1007/s11104-017-3381-z

Kassam A, Friedrich T, Derpsch R, et al (2012) Conservation agriculture in the dry Mediterranean climate. F Crop Res 132:7-17. doi: 10.1016/j.fcr.2012.02.023

Kay BD, VandenBygaart AJ (2002) Conservation tillage and depth stratification of porosity and soil organic matter. Soil Tillage Res 66:107-118. doi: 10.1016/S01671987(02)00019-3

Keesstra S, Pereira P, Novara A, et al (2016) Effects of soil management techniques on soil water erosion in apricot orchards. Sci Total Environ. doi: 10.1016/j.scitotenv.2016.01.182

Kemmitt SJ, Wright D, Goulding KWT, Jones DL (2006) pH regulation of carbon and nitrogen dynamics in two agricultural soils. Soil Biol Biochem 38:898-911. doi: 10.1016/j.soilbio.2005.08.006

Kirkham D, Bartholomew W V. (1954) Equations for Following Nutrient Transformations in Soil, Utilizing Tracer Data1. Soil Sci Soc Am J 18:33. doi: 10.2136/sssaj1954.03615995001800010009x

Koch AL (2005) Bacterial choices for the consumption of multiple resources for current and future needs. Microb. Ecol.

Kristensen HL, McCarty GW, Meisinger JJ (2010) Effects of Soil Structure Disturbance on Mineralization of Organic Soil Nitrogen. Soil Sci Soc Am J. doi: 10.2136/sssaj2000.641371x

Kumar CG, Takagi H (1999) Microbial alkaline proteases: From a bioindustrial viewpoint. Biotechnol. Adv. 17:561-594

Kuzyakov Y, Xu X (2013) Competition between roots and microorganisms for nitrogen: Mechanisms and ecological relevance. New Phytol 198:656-669. doi: 10.1111/nph.12235

Ladd JN, Butler JHA (1972) Short-term assays of soil proteolytic enzyme activities using proteins and dipeptide derivatives as substrates. Soil Biol Biochem 4:19-30. doi: 10.1016/0038-0717(72)90038-7

Lagomarsino A, Agnelli AE, Pastorelli R, et al (2016) Past water management affected GHG production and microbial community pattern in Italian rice paddy soils. Soil Biol Biochem 93:17-27. doi: 10.1016/j.soilbio.2015.10.016

Laine M, Rütting T, Alakukku L, et al (2017) Process rates of nitrogen cycle in uppermost topsoil after harvesting in no-tilled and ploughed agricultural clay soil. Nutr Cycl Agroecosystems 1-11. doi: 10.1007/s10705-017-9825-2

Lal R (2004) Soil carbon sequestration impacts on global climate change and food security. Science (80- ) 304:1623-1627 ST-Soil carbon sequestration impacts. doi: 10.1126/science. 1097396 [doi]

Lal R (2016) Beyond COP 21: Potential and challenges of the "4 per Thousand" initiative. J Soil Water Conserv. doi: 10.2489/jswc.71.1.20a

Lal R, Delgado JA, Groffman PM, et al (2011) Management to mitigate and adapt to climate change. J Soil Water Conserv 66:276-285. doi: 10.2489/jswc.66.4.276 
Landi L, Renella G, Giagnoni L, et al (2011) Activities of Proteolytic Enzymes. In: Methods of Soil Enzymology. Soil Science Society of America, pp 247-260

Leigh J, Hodge A, Fitter AH (2009) Arbuscular mycorrhizal fungi can transfer substantial amounts of nitrogen to their host plant from organic material - Leigh 2008 - New Phytologist - Wiley Online Library.pdf. New Phytol 181:199-207

Leitner S, Homyak PM, Blankinship JC, et al (2017) Linking NO and N2O emission pulses with the mobilization of mineral and organic $\mathrm{N}$ upon rewetting dry soils. Soil Biol Biochem 115:461-466. doi: 10.1016/j.soilbio.2017.09.005

León P, Espejo R, Gómez-Paccard C, et al (2017) No tillage and sugar beet foam amendment enhanced microbial activity of degraded acidic soils in South West Spain. Appl Soil Ecol 109:69-74. doi: 10.1016/j.apsoil.2016.09.012

Li S, Jiang X, Wang X, Wright AL (2015) Tillage effects on soil nitrification and the dynamic changes in nitrifying microorganisms in a subtropical rice-based ecosystem: A long-term field study. Soil Tillage Res 150:132-138. doi: 10.1016/j.still.2015.02.005

Li Y, Chapman SJ, Nicol GW, Yao H (2018) Nitrification and nitrifiers in acidic soils. Soil Biol Biochem 116:290-301. doi: 10.1016/j.soilbio.2017.10.023

Liao P, Huang S, van Gestel NC, et al (2018) Liming and straw retention interact to increase nitrogen uptake and grain yield in a double rice-cropping system. F Crop Res 216:217-224. doi: 10.1016/j.fcr.2017.11.026

Liu B, Frostegård Å, Bakken LR (2014) Impaired Reduction of N2O to N2 in Acid Soils Is Due to a Posttranscriptional Interference with the Expression of nosZ. MBio 5:545-558. doi: 10.1128/mBio.01383-14.Editor

Liu B, Mørkved PT, Frostegård Å, Bakken LR (2010) Denitrification gene pools, transcription and kinetics of $\mathrm{NO}, \mathrm{N} 2 \mathrm{O}$ and $\mathrm{N} 2$ production as affected by soil $\mathrm{pH}$. FEMS Microbiol Ecol. doi: 10.1111/j.1574-6941.2010.00856.x

López-Garrido R, Madejón E, León-Camacho M, et al (2014) Reduced tillage as an alternative to no-tillage under Mediterranean conditions: A case study. Soil Tillage Res 140:40-47. doi: 10.1016/j.still.2014.02.008

López-Gutiérrez JC, Henry S, Hallet S, et al (2004) Quantification of a novel group of nitrate-reducing bacteria in the environment by real-time PCR. J Microbiol Methods 57:399-407. doi: 10.1016/j.mimet.2004.02.009

Lorenz K, Lal R (2014) Soil organic carbon sequestration in agroforestry systems. A review. Agron Sustain Dev 34:443-454. doi: 10.1007/s13593-014-0212-y

Lovelock CE, Wright SF, Clark DA, Ruess RW (2004) Soil stocks of glomalin produced by arbuscular mycorrhizal fungi across a tropical rain forest landscape. $\mathrm{J}$ Ecol 92:278-287. doi: 10.1111/j.0022-0477.2004.00855.x

Luxhøi J, Fillery IRP, Murphy D V., et al (2008a) Distribution and controls on gross N mineralization-immobilization-turnover in soil subjected to zero tillage. Eur J Soil Sci 59:190-197. doi: 10.1111/j.1365-2389.2007.00969.x

Luxhøi J, Fillery IRP, Recous S, Jensen LS (2008b) Carbon and N turnover in moist sandy soil following short exposure to a range of high soil temperature regimes. Aust J Soil Res 46:710-718. doi: 10.1071/SR08044

Madejón E, Moreno F, Murillo JM, Pelegrín F (2007) Soil biochemical response to 
long-term conservation tillage under semi-arid Mediterranean conditions. Soil Tillage Res 94:346-352. doi: 10.1016/j.still.2006.08.010

Madejón E, Murillo JM, Moreno F, et al (2009) Effect of long-term conservation tillage on soil biochemical properties in Mediterranean Spanish areas. Soil Tillage Res 105:55-62. doi: 10.1016/j.still.2009.05.007

Manzoni S, Schaeffer SM, Katul G, et al (2014) A theoretical analysis of microbial ecophysiological and diffusion limitations to carbon cycling in drying soils. Soil Biol Biochem 73:69-83. doi: 10.1016/j.soilbio.2014.02.008

Mariscal-Sancho I, Peregrina F, Mendiola MA, et al (2009) Exchange complex composition in mediterranean ultisols under various types of vegetation and soil uses. Soil Sci. doi: 10.1097/SS.0b013e3181a974fe

Mariscal I, Peregrina F, Terefe T, et al (2007) Evolution of some physical properties related to soil quality in the degraded ecosystems of "raña" formations from SW Spain. Sci Total Environ. doi: 10.1016/j.scitotenv.2007.01.025

Martín-Lammerding D, Navas M, Albarrán M, et al (2015) Long term management systems under semiarid conditions: Influence on labile organic matter, Bglucosidase activity and microbial efficiency. Appl Soil Ecol 96:296-305. doi: 10.1016/j.apsoil.2015.08.021

Martins CSC, Nazaries L, Macdonald CA, et al (2015) Water availability and abundance of microbial groups are key determinants of greenhouse gas fluxes in a dryland forest ecosystem. Soil Biol Biochem. doi: 10.1016/j.soilbio.2015.03.012

Mazzoncini M, Antichi D, Di Bene C, et al (2016) Soil carbon and nitrogen changes after 28 years of no-tillage management under Mediterranean conditions. Eur J Agron 77:156-165. doi: 10.1016/j.eja.2016.02.011

McGonigle TP, Miller MH, Evans DG, et al (1990) A new method which gives an objective measure of colonization of roots by vesicular-arbuscular mycorrhizal fungi. New Phytol 115:495-501. doi: 10.1111/j.1469-8137.1990.tb00476.x

McMillan AMS, Pal P, Phillips RL, et al (2016) Can pH amendments in grazed pastures help reduce $\mathrm{N} 2 \mathrm{O}$ emissions from denitrification? - The effects of liming and urine addition on the completion of denitrification in fluvial and volcanic soils. Soil Biol Biochem. doi: 10.1016/j.soilbio.2015.10.013

Mehlich A (1984) Mehlich 3 soil test extractant: A modification of Mehlich 2 extractant. Commun Soil Sci Plant Anal 15:1409-1416. doi: $10.1080 / 00103628409367568$

Meng L, Zhang A, Wang F, et al (2015) Arbuscular mycorrhizal fungi and rhizobium facilitate nitrogen uptake and transfer in soybean/maize intercropping system. Front Plant Sci 6:1-10. doi: 10.3389/fpls.2015.00339

Meriño-Gergichevich C, Alberdi M, Ivanov a G, Reyes-Diaz M (2010) Al 3+ - Ca2+ Interaction in plants growing in acid soils: al-phytotoxicity response to calcareous amendments.. J soil Sci plant Nutr

Mijangos I, Albizu I, Epelde L, et al (2010) Effects of liming on soil properties and plant performance of temperate mountainous grasslands. J Environ Manage 91:2066-2074. doi: 10.1016/j.jenvman.2010.05.011

Miller AE, Schimel JP, Meixner T, et al (2005) Episodic rewetting enhances carbon and 
nitrogen release from chaparral soils. Soil Biol Biochem. doi: 10.1016/j.soilbio.2005.03.021

Miller KS, Geisseler D (2018) Temperature sensitivity of nitrogen mineralization in agricultural soils. $853-860$

Miranda KM, Espey MG, Wink DA (2001) A Rapid, Simple Spectrophotometric Method for Simultaneous Detection of Nitrate and Nitrite. Nitric Oxide 5:62-71. doi: 10.1006/niox.2000.0319

Montgomery DR (2012) Dirt: The erosion of civilizations: With a new preface

Moreira FM de S, de Carvalho TS, Siqueira JO (2010) Effect of fertilizers, lime, and inoculation with rhizobia and mycorrhizal fungi on the growth of four leguminous tree species in a low-fertility soil. Biol Fertil Soils 46:771-779. doi: 10.1007/s00374-010-0477-5

Mortimer PE, Pérez-Fernández MA, Valentine AJ (2008) The role of arbuscular mycorrhizal colonization in the carbon and nutrient economy of the tripartite symbiosis with nodulated Phaseolus vulgaris. Soil Biol Biochem 40:1019-1027. doi: 10.1016/j.soilbio.2007.11.014

Muñoz-Rojas M, Jordán A, Zavala LM, et al (2015) Impact of Land Use and Land Cover Changes on Organic Carbon Stocks in Mediterranean Soils (1956-2007). L Degrad Dev. doi: 10.1002/ldr.2194

Munroe JW, McCormick I, Deen W, Dunfield KE (2016) Effects of 30 Years of Crop Rotation and Tillage on Bacterial and Archaeal Ammonia Oxidizers. J Environ Qual 45:940. doi: 10.2134/jeq2015.06.0331

Murphy J, Riley J (1962) A modified single solution method for the determinatio of phosphate in natural waters. Anal Chem ACTA 27:31-36. doi: 10.1016/S00032670(00)88444-5

Murphy D V., Recous S, Stockdale EA, et al (2003) Gross nitrogen fluxes in soil: theory, measurement and application of $15 \mathrm{~N}$ pool dilution techniques. Adv. Agron. 79:69-118

Muruganandam S, Israel DW, Robarge WP (2010) Nitrogen Transformations and Microbial Communities in Soil Aggregates from Three Tillage Systems. Soil Sci Soc Am J 74:120. doi: 10.2136/sssaj2009.0006

Muyzer G, Teske A, Wirsen CO, Jannasch HW (1995) Phylogenetic relationships of Thiomicrospira species and their identification in deep-sea hydrothermal vent samples by denaturing gradient gel electrophoresis of $16 \mathrm{~S}$ rDNA fragments. Arch Microbiol 164:165-172. doi: 10.1007/BF02529967

Nannipieri P, Ceccanti B, Cervelli S, Matarese E (1980) Extraction of Phosphatase, Urease, Proteases, Organic Carbon, and Nitrogen from Soil1. Soil Sci Soc Am J 44:1011. doi: 10.2136/sssaj1980.03615995004400050028x

Nannipieri P, Giagnoni L, Renella G, Puglisi E (2012) Soil enzymology : classical and molecular approaches. 743-762. doi: 10.1007/s00374-012-0723-0

Nannipieri P, Trasar-Cepeda C, Dick RP (2018) Soil enzyme activity: a brief history and biochemistry as a basis for appropriate interpretations and meta-analysis. Biol Fertil Soils 54:11-19. doi: 10.1007/s00374-017-1245-6

Nelson DW, Sommers LE, Sparks DL, et al (1996) Total carbon, organic carbon, and 
organic matter. $961-1010$

Németh DD, Wagner-Riddle C, Dunfield KE (2014) Abundance and gene expression in nitrifier and denitrifier communities associated with a field scale spring thaw N2O flux event. Soil Biol Biochem 73:1-9. doi: 10.1016/j.soilbio.2014.02.007

Nicol GW, Leininger S, Schleper C, Prosser JI (2008) The influence of soil pH on the diversity, abundance and transcriptional activity of ammonia oxidizing archaea and bacteria. Environ Microbiol 10:2966-2978. doi: 10.1111/j.14622920.2008.01701.x

Noll L, Zhang S, Wanek W (2019) Novel high-throughput approach to determine key processes of soil organic nitrogen cycling: Gross protein depolymerization and microbial amino acid uptake. Soil Biol Biochem. doi: 10.1016/j.soilbio.2018.12.005

Nouri E, Breuillin-Sessoms F, Feller U, Reinhardt D (2014) Phosphorus and Nitrogen Regulate Arbuscular Mycorrhizal Symbiosis in <italic>Petunia hybrida</italic>. PLoS One 9:e90841. doi: 10.1371/journal.pone.0090841

Novara A, Gristina L, Saladino SS, et al (2011) Soil erosion assessment on tillage and alternative soil managements in a Sicilian vineyard. Soil Tillage Res. doi: 10.1016/j.still.2011.09.007

Obia A, Cornelissen G, Mulder J, Dörsch P (2015) Effect of soil pH increase by biochar on $\mathrm{NO}, \mathrm{N} 2 \mathrm{O}$ and $\mathrm{N} 2$ production during denitrification in acid soils. PLoS One 10:1-19. doi: 10.1371/journal.pone.0138781

Obia A, Mulder J, Martinsen V, et al (2016) In situ effects of biochar on aggregation, water retention and porosity in light-textured tropical soils. Soil Tillage Res 155:35-44. doi: 10.1016/j.still.2015.08.002

Okano Y, Hristova KR, Leutenegger CM, et al (2004) Application of Real-Time PCR To Study Effects of Ammonium on Population Size of Ammonia-Oxidizing Bacteria in Soil. Appl Environ Microbiol 70:1008-1016. doi: 10.1128/AEM.70.2.1008-1016.2004

Panettieri M, Knicker H, Murillo JM, et al (2014) Soil organic matter degradation in an agricultural chronosequence under different tillage regimes evaluated by organic matter pools, enzymatic activities and CPMAS 13 C NMR. Soil Biol Biochem 78:170-181. doi: 10.1016/j.soilbio.2014.07.021

Paradelo R, Virto I, Chenu C (2015) Net effect of liming on soil organic carbon stocks : A review. Agric Ecosyst Environ 98-107. doi: 10.1016/j.agee.2015.01.005

Parham JA, Deng SP (2000) Detection, quantification and characterization of Bglucosaminidase activity in soil. Soil Biol Biochem 32:1183-1190

Parker SS, Schimel JP (2011) Soil nitrogen availability and transformations differ between the summer and the growing season in a California grassland. Appl Soil Ecol 48:185-192. doi: 10.1016/j.apsoil.2011.03.007

Pastorelli R, Landi S, Trabelsi D, et al (2011) Effects of soil management on structure and activity of denitrifying bacterial communities. Appl Soil Ecol. doi: 10.1016/j.apsoil.2011.07.002

Peregrina Alonso F, Santano Arias J, Ordónez Fernández R, et al (2006) Agronomic implications of the supply of lime and gypsum by-products to Palexerults from 
western Spain. Soil Sci. doi: 10.1097/01.ss.0000200557.253069.50

Peregrina F, Mariscal I, Ordóñez R, et al (2008) Agronomic Implications of Converter Basic Slag as a Magnesium Source on Acid Soils. Soil Sci Soc Am J. doi: 10.2136/sssaj2006.0197

Pereira e Silva MC, Poly F, Guillaumaud N, et al (2012) Fluctuations in ammonia oxidizing communities across agricultural soils are driven by soil structure and $\mathrm{pH}$. Front Microbiol 3:. doi: 10.3389/fmicb.2012.00077

Pérez-Tienda J, Valderas A, Camañes G, et al (2012) Kinetics of NH 4 + uptake by the arbuscular mycorrhizal fungus Rhizophagus irregularis. Mycorrhiza 22:485-491. doi: $10.1007 / \mathrm{s} 00572-012-0452-0$

Piotrowska-Dlugosz A (2014) Enzymes and soil fertility. In: Gianfreda L, Rao M (eds). OMICS sBook Group, pp 44-79

Pittelkow CM, Linquist BA, Lundy ME, et al (2015) When does no-till yield more? A global meta-analysis. F Crop Res. doi: 10.1016/j.fcr.2015.07.020

Plaza-Bonilla D, Álvaro-Fuentes J, Cantero-Martínez C (2014) Identifying soil organic carbon fractions sensitive to agricultural management practices. Soil Tillage Res 139:19-22. doi: 10.1016/j.still.2014.01.006

Polania J, Poschenrieder C, Rao I, Beebe S (2016) Estimation of phenotypic variability in symbiotic nitrogen fixation ability of common bean under drought stress using $15 \mathrm{~N}$ natural abundance in grain. Eur J Agron. doi: 10.1016/j.eja.2016.05.014

Pommier T, Cantarel AAM, Grigulis K, et al (2018) The added value of including key microbial traits to determine nitrogen-related ecosystem services in managed grasslands. J Appl Ecol 55:49-58. doi: 10.1111/1365-2664.13010

Prosser JI, Nicol GW (2012) Archaeal and bacterial ammonia-oxidisers in soil: the quest for niche specialisation and differentiation. Trends Microbiol 20:523-531. doi: 10.1016/j.tim.2012.08.001

Pulleman M., Six J, Uyl A, et al (2005) Earthworms and management affect organic matter incorporation and microaggregate formation in agricultural soils. Appl Soil Ecol 29:1-15. doi: 10.1016/j.apsoil.2004.10.003

Qin HL, Yuan HZ, Zhang H, et al (2013) Ammonia-oxidizing archaea are more important than ammonia-oxidizing bacteria in nitrification and NO3--N loss in acidic soil of sloped land. Biol Fertil Soils 49:767-776. doi: 10.1007/s00374-0120767-1

Qiu H, Ge T, Liu J, et al (2018) Effects of biotic and abiotic factors on soil organic matter mineralization: Experiments and structural modeling analysis. Eur J Soil Biol 84:27-34. doi: 10.1016/j.ejsobi.2017.12.003

Quilchano C, Marañón T (2002) Dehydrogenase activity in Mediterranean forest soils. Biol Fertil Soils 35:102-107. doi: 10.1007/s00374-002-0446-8

R. Weil R, R. Islam K, A. Stine M, et al (2003) Estimating active carbon for soil quality assessment: A simplified method for laboratory and field use. Am J Altern Agric 18:3-17. doi: 10.1079/AJAA200228

Redel YD, Rubio R, Rouanet JL, Borie F (2007) Phosphorus bioavailability affected by tillage and crop rotation on a Chilean volcanic derived Ultisol. Geoderma 139:388-396. doi: 10.1016/j.geoderma.2007.02.018 
Rillig MC (2004) Arbuscular mycorrhizae, glomalin, and soil aggregation. Can J Soil Sci 84:355-363. doi: 10.4141/S04-003

Roldán A, Salinas-García JR, Alguacil MM, et al (2005) Soil enzyme activities suggest advantages of conservation tillage practices in sorghum cultivation under subtropical conditions. Geoderma 129:178-185. doi: 10.1016/j.geoderma.2004.12.042

Romanyà J, Rovira P (2011) An appraisal of soil organic C content in Mediterranean agricultural soils. Soil Use Manag. doi: 10.1111/j.1475-2743.2011.00346.x

Romero-Díaz A, Ruiz-Sinoga JD, Robledano-Aymerich F, et al (2017) Ecosystem responses to land abandonment in Western Mediterranean Mountains. Catena. doi: 10.1016/j.catena.2016.08.013

Ros GH (2012) Predicting soil N mineralization using organic matter fractions and soil properties: A re-analysis of literature data. Soil Biol Biochem. doi: 10.1016/j.soilbio.2011.10.015

Ros GH, Temminghoff EJM, Hoffland E (2011) Nitrogen mineralization: A review and meta-analysis of the predictive value of soil tests. Eur. J. Soil Sci.

Rotthauwe J-H, Witzel K-P, Werner L (1997) The ammonia monooxygenase structural gene amoA as a functional marker Molecular fine-scale analysis of natural ammonia-oxidizing populations.pdf. Appl Environ Microbiol 63:4704-4712. doi: 10.1128/AEM.NA

Rousk J, Bååth E, Brookes PC, et al (2010) Soil bacterial and fungal communities across a $\mathrm{pH}$ gradient in an arable soil. ISME J 4:1340-51. doi: 10.1038/ismej.2010.58

Rousk J, Demoling LA, Bahr A, BÃ¥Ã¥th E (2008) Examining the fungal and bacterial niche overlap using selective inhibitors in soil. FEMS Microbiol Ecol 63:350-358. doi: 10.1111/j.1574-6941.2008.00440.x

Ruser R, Flessa H, Russow R, et al (2006) Emission of N2O, N2 and CO2 from soil fertilized with nitrate: Effect of compaction, soil moisture and rewetting. Soil Biol Biochem. doi: 10.1016/j.soilbio.2005.05.005

Safarik I, Santruckova H (1992) Direct determination of total soil carbohydrate content. Plant Soil 143:109-114

Sainju UM, Lenssen AW, Allen BL, et al (2018) Nitrogen balance in dryland agroecosystem in response to tillage, crop rotation, and cultural practice. Nutr Cycl Agroecosystems 110:467-483. doi: 10.1007/s10705-018-9909-7

Sanchez-Martin L, Sanz-Cobena A, Meijide A, et al (2010) The importance of the fallow period for $\mathrm{N} 2 \mathrm{O}$ and $\mathrm{CH} 4$ fluxes and nitrate leaching in a Mediterranean irrigated agroecosystem. Eur J Soil Sci 61:710-720. doi: 10.1111/j.13652389.2010.01278.x

Sanz-Cobena A, Lassaletta L, Aguilera E, et al (2017) Strategies for greenhouse gas emissions mitigation in Mediterranean agriculture: A review. "Agriculture, Ecosyst Environ 238:5-24. doi: 10.1016/j.agee.2016.09.038

Šarauskis E, Buragiene S, Masilionyte L, et al (2014) Energy balance, costs and CO2 analysis of tillage technologies in maize cultivation. Energy. doi: 10.1016/j.energy.2014.02.090 
Sardans J, Pen J, Estiarte M (2008) Changes in soil enzymes related to C and N cycle and in soil $\mathrm{C}$ and $\mathrm{N}$ content under prolonged warming and drought in a Mediterranean shrubland. 39:223-235. doi: 10.1016/j.apsoil.2007.12.011

Sardans J, Peñuelas J (2013) Plant-soil interactions in Mediterranean forest and shrublands : impacts of climatic change. 1-33. doi: 10.1007/s11104-013-1591-6

Sardans J, Peñuelas J (2010) Soil Enzyme Activity in a Mediterranean Forest after Six Years of Drought. 74:838-851. doi: 10.2136/sssaj2009.0225

Sastre B, Barbero-Sierra C, Bienes R, et al (2017) Soil loss in an olive grove in Central Spain under cover crops and tillage treatments, and farmer perceptions. J Soils Sediments. doi: 10.1007/s11368-016-1589-9

Scala DJ, Kerkhof LJ (1998) Nitrous oxide reductase (nosZ) gene-specific PCR primers for detection of denitrifiers and three nosZ genes from marine sediments. FEMS Microbiol Lett. doi: 10.1016/S0378-1097(98)00103-7

Schaeffer SM, Homyak PM, Boot CM, et al (2017) Soil carbon and nitrogen dynamics throughout the summer drought in a California annual grassland. Soil Biol Biochem 115:54-62. doi: 10.1016/j.soilbio.2017.08.009

Schimel JP, Bennett J (2004) Nitrogen mineralization: challenges of a changing paradigm. Ecology 85:591-602. doi: 10.1890/03-8002

Schimel JP, Weintraub MN (2003) The implications of exoenzyme activity on microbial carbon and nitrogen limitation in soil: A theoretical model. Soil Biol Biochem. doi: 10.1016/S0038-0717(03)00015-4

Schoch CL, Seifert KA, Huhndorf S, et al (2012) Nuclear ribosomal internal transcribed spacer (ITS) region as a universal DNA barcode marker for Fungi. Proc Natl Acad Sci 109:6241-6246. doi: 10.1073/pnas.1117018109

Schomberg HH, Wietholter S, Griffin TS, et al (2009) Assessing Indices for Predicting Potential Nitrogen Mineralization in Soils under Different Management Systems. Soil Sci Soc Am J 73:1575. doi: 10.2136/sssaj2008.0303

Schrumpf M, Kaiser K, Guggenberger G, et al (2013) Storage and stability of organic carbon in soils as related to depth, occlusion within aggregates, and attachment to minerals. Biogeosciences 10:1675-1691. doi: 10.5194/bg-10-1675-2013

Schulten HR, Schnitzer M (1997) The chemistry of soil organic nitrogen: A review. Biol. Fertil. Soils 26:1-15

Segal LM, Miller DN, McGhee RP, et al (2017) Bacterial and archaeal ammonia oxidizers respond differently to long-term tillage and fertilizer management at a continuous maize site. Soil Tillage Res 168:110-117. doi: 10.1016/j.still.2016.12.014

Seguel A, Castillo C., Morales A, et al (2016a) Arbuscular Mycorrhizal symbiosis in four Al-tolerant wheat genotypes grown in an acidic Andisol. J soil Sci plant Nutr 16:0-0. doi: 10.4067/s0718-95162016005000013

Seguel A, Cumming J, Cornejo P, Borie F (2016b) Aluminum tolerance of wheat cultivars and relation to arbuscular mycorrhizal colonization in a non-limed and limed Andisol. Appl Soil Ecol 108:1-18. doi: 10.1016/j.apsoil.2016.08.014

Seguel A, Cumming JR, Klugh-Stewart K, et al (2013) The role of arbuscular mycorrhizas in decreasing aluminium phytotoxicity in acidic soils: A review. 
Mycorrhiza 23:167-183. doi: 10.1007/s00572-013-0479-x

Serra-Wittling C, Houot S, Barriuso E (1995) Soil enzymatic response to addition of municipal solid-waste compost. Biol Fertil Soils 20:226-236. doi: 10.1007/BF00336082

Serra P, Pons X, Saurí D (2008) Land-cover and land-use change in a Mediterranean landscape: A spatial analysis of driving forces integrating biophysical and human factors. Appl Geogr. doi: 10.1016/j.apgeog.2008.02.001

Sharma P, Abrol V, Sharma RK (2011) Impact of tillage and mulch management on economics, energy requirement and crop performance in maize-wheat rotation in rainfed subhumid inceptisols, India. Eur J Agron. doi: 10.1016/j.eja.2010.10.003

Sharma S, Aneja MK, Mayer J, et al (2005) Diversity of Transcripts of Nitrite Reductase Genes (nirK and. Appl Environ Microbiol 71:2001-2007. doi: 10.1128/AEM.71.4.2001

Šimek M, Cooper JE (2002) The influence of soil pH on denitrification: Progress towards the understanding of this interaction over the last 50 years. Eur J Soil Sci. doi: 10.1046/j.1365-2389.2002.00461.x

Sinsabaugh RL, Hill BH, Follstad Shah JJ (2009) Ecoenzymatic stoichiometry of microbial organic nutrient acquisition in soil and sediment. Nature 462:795-798. doi: $10.1038 /$ nature 08632

Six J, Elliott ET, Paustian K (2000) Soil macroaggregate turnover and microaggregate formation: A mechanism for $\mathrm{C}$ sequestration under no-tillage agriculture. Soil Biol Biochem. doi: 10.1016/S0038-0717(00)00179-6

Six, J., Elliott, E. T., \& Paustian, K. (1999). Aggregate and soil organic matter dynamics under conventional and no-tillage systems. Soil Sci Soc Am J. 63(5), 1350-1358.

Smith SE, Read D (2008) 15 - The roles of mycorrhizas in successional processes and in selected biomes. In: Mycorrhizal Symbiosis. pp 525-572

Sorensen JN, Larsen J, Jakobsen I (2008) Pre-inoculation with arbuscular mycorrhizal fungi increases early nutrient concentration and growth of field-grown leeks under high productivity conditions. Plant Soil 307:135-147. doi: 10.1007/s11104-0089591-7

Sowden FJ, Chen Y, Schnitzer M (1977) The nitrogen distribution in soils formed under widely differing climatic conditions. Geochim Cosmochim Acta 41:1524-1526. doi: 10.1016/0016-7037(77)90257-5

Steinweg JM, Dukes JS, Paul EA, Wallenstein MD (2013) Microbial responses to multi-factor climate change: effects on soil enzymes. 4:1-11. doi: 10.3389/fmicb.2013.00146

Stewart FJ, Ulloa O, DeLong EF (2012) Microbial metatranscriptomics in a permanent marine oxygen minimum zone. Environ Microbiol 14:23-40. doi: 10.1111/j.14622920.2010.02400.x

Strickland MS, Rousk J (2010) Considering fungal : Bacterial dominance in soils Methods , controls , and ecosystem implications. doi: 10.1016/j.soilbio.2010.05.007

Strobl W, Traunmueller M (1996) $\beta$-Glucosidase activity. In: Schinner F, Öhlinger R, 
Kandeler E, Margesin R (eds) Methods in Soil Biology. Springer Berlin Heidelberg, Berlin, Heidelberg, pp 198-200

Suseela V, Conant RT, Wallenstein MD, Dukes JS (2012) Effects of soil moisture on the temperature sensitivity of heterotrophic respiration vary seasonally in an oldfield climate change experiment. Glob Chang Biol 18:336-348. doi: 10.1111/j.1365-2486.2011.02516.x

Tabatabai MA, Bremner JM (1970) Arylsulfatase Activity of Soils1. Soil Sci Soc Am J 34:225. doi: 10.2136/sssaj1970.03615995003400020016x

Tabatabai MA, Bremner JM (1969) Use of p-nitrophenyl phosphate for assay of soil phosphatase activity. Soil Biol Biochem 1:301-307. doi: 10.1016/00380717(69)90012-1

Tabatabai MEMA (2003) Effects of liming and tillage systems on microbial biomass and glycosidases in soils. 51-61. doi: 10.1007/s00374-003-0664-8

Tang H, Long L, Li W, ChaoJie B (2009) Effect of land use type on profile distribution of glomalin. Chinese J Eco-Agriculture 17:1137-1142. doi: 10.3724/SP.J.1011.2009.01137

Taylor JP, Wilson B, Mills MS, Burns RG (2002) Comparison of microbial numbers and enzymatic activities in surface soils and subsoils using various techniques. Soil Biol Biochem 34:387-401. doi: 10.1016/S0038-0717(01)00199-7

Teutscherova N, Houška J, Navas M, et al (2018) Leaching of ammonium and nitrate from Acrisol and Calcisol amended with holm oak biochar: A column study. Geoderma 323:136-145. doi: 10.1016/j.geoderma.2018.03.004

Teutscherova N, Vazquez E, Arevalo A, et al (2019) Differences in arbuscular mycorrhizal colonization and $\mathrm{P}$ acquisition between genotypes of the tropical Brachiaria grasses: is there a relation with BNI activity? Biol Fertil Soils. doi: 10.1007/s00374-019-01353-y

Teutscherova N, Vazquez E, Masaguer A, et al (2017a) Comparison of lime- and biochar-mediated $\mathrm{pH}$ changes in nitrification and ammonia oxidizers in degraded acid soil. Biol Fertil Soils 53:811-821. doi: 10.1007/s00374-017-1222-0

Teutscherova N, Vazquez E, Santana D, et al (2017b) Influence of pruning waste compost maturity and biochar on carbon dynamics in acid soil: Incubation study. Eur J Soil Biol 78:66-74. doi: 10.1016/j.ejsobi.2016.12.001

Theodorakopoulos N, Lognoul M, Degrune F, et al (2017) Increased expression of bacterial amoA during an $\mathrm{N} 2 \mathrm{O}$ emission peak in an agricultural field. Agric Ecosyst Environ. doi: 10.1016/j.agee.2016.12.002

Throbäck IN, Enwall K, Jarvis Å, Hallin S (2004) Reassessing PCR primers targeting nirS, nirK and nosZ genes for community surveys of denitrifying bacteria with DGGE. FEMS Microbiol Ecol. doi: 10.1016/j.femsec.2004.04.011

Tian H, Chen G, Zhang C, et al (2010) Pattern and variation of C:N:P ratios in China's soils: A synthesis of observational data. Biogeochemistry. doi: 10.1007/s10533009-9382-0

Tiritan CS, Büll LT, Crusciol CAC, et al (2016) Tillage system and lime application in a tropical region: Soil chemical fertility and corn yield in succession to degraded pastures. Soil Tillage Res 155:437-447. doi: 10.1016/j.still.2015.06.012 
Trevors JT, Mayfield CI, Inniss WE (1982) Measurement of Electron Transport System (ETS) activity in soil. Microb Ecol 8:163-168. doi: 10.1007/BF02010449

Triplett GB, Dick WA (2008) No-tillage crop production: A revolution in agriculture! Agron. J.

van Kessel C, Clough T, van Groenigen JW (2009) Dissolved Organic Nitrogen: An Overlooked Pathway of Nitrogen Loss from Agricultural Systems? J Environ Qual. doi: $10.2134 /$ jeq2008.0277

van Kessel C, Venterea R, Six J, et al (2013) Climate, duration, and N placement determine $\mathrm{N} 2 \mathrm{O}$ emissions in reduced tillage systems: A meta-analysis. Glob. Chang. Biol.

Vance ED, Brookes PC, Jenkinson DS (1987) An extraction method for measuring soil microbial biomass C. Soil Biol Biochem 19:703-707. doi: 10.1016/00380717(87)90052-6

Varela-Ortega C, Irene B-G, Esteve P, et al (2016) How can irrigated agriculture adapt to climate change? Insights from the Guadiana Basin in Spain. Reg Environ Chang 16:59-70. doi: 10.1007/s10113-014-0720-y

Vazquez E, Benito M, Espejo R, Teutscherova N (2019) Effects of no-tillage and liming amendment combination on soil carbon and nitrogen mineralization. Eur J Soil Biol 93:103090. doi: 10.1016/j.ejsobi.2019.103090

Vazquez E, Teutscherova N, Almorox J, et al (2017) Seasonal variation of microbial activity as affected by tillage practice and sugar beet foam amendment under Mediterranean climate. Appl Soil Ecol 117-118:70-80. doi: 10.1016/j.apsoil.2017.04.013

Verzeaux J, Hirel B, Dubois F, et al (2017) Agricultural practices to improve nitrogen use efficiency through the use of arbuscular mycorrhizae: Basic and agronomic aspects. Plant Sci 264:48-56. doi: 10.1016/j.plantsci.2017.08.004

Verzeaux J, Roger D, Lacoux J, et al (2016) In Winter Wheat, No-Till Increases Mycorrhizal Colonization thus Reducing the Need for Nitrogen Fertilization. Agronomy 6:38. doi: 10.3390/agronomy6020038

Vierheilig H, Coughlan AP, Wyss URS, Recherche C De (1998) Ink and Vinegar, a Simple Staining Technique for Arbuscular-Mycorrhizal Fungi. 64:5004-5007

Vita P De (2016) No-tillage and conventional tillage effects on durum wheat yield, grain quality and soil moisture content in southern Italy. doi: 10.1016/j.still.2006.01.012

von Uexküll HR, Mutert E (1995) Global extent, development and economic impact of acid soils. Plant Soil. doi: 10.1007/BF00009558

Vranova V, Rejsek K, Formanek P (2013) Proteolytic activity in soil: A review. Appl Soil Ecol 70:23-32. doi: 10.1016/j.apsoil.2013.04.003

Wade J, Waterhouse H, Roche LM, Horwath WR (2018) Structural equation modeling reveals iron (hydr)oxides as a strong mediator of $\mathrm{N}$ mineralization in California agricultural soils. Geoderma 315:120-129. doi: 10.1016/j.geoderma.2017.11.039

Walkley A, Black IA (1934) An examination of the Degtjareff method for determining soil organic matter, and a proposed modification of the chromic acid titration method. Soil Sci 37:29-38 
Wallenstein MD, Weintraub MN (2008) Emerging tools for measuring and modeling the in situ activity of soil extracellular enzymes. Soil Biol Biochem. doi: 10.1016/j.soilbio.2008.01.024

Wang P, Wang Y, Wu QS (2016) Effects of soil tillage and planting grass on arbuscular mycorrhizal fungal propagules and soil properties in citrus orchards in southeast China. Soil Tillage Res 155:54-61. doi: 10.1016/j.still.2015.07.009

Waring SA, Bremner JM (1964) Ammonium Production in Soil under Waterlogged Conditions as an Index of Nitrogen Availability. Nature 201:951-952. doi: $10.1038 / 201951 \mathrm{a} 0$

Weintraub MN, Schimel JP (2005) Seasonal protein dynamics in Alaskan arctic tundra soils. Soil Biol Biochem 37:1469-1475. doi: 10.1016/j.soilbio.2005.01.005

West TO, Post WM (2002) Soil Organic Carbon Sequestration Rates by Tillage and Crop Rotation. Soil Sci Soc Am J. doi: 10.2136/sssaj2002.1930

Williams A, Davis AS, Jilling A, et al (2017) Reconciling opposing soil processes in row-crop agroecosystems via soil functional zone management. Agric Ecosyst Environ. doi: 10.1016/j.agee.2016.11.012

Wolters V, Joergensen RG (1991) Microbial carbon turnover in beech forest soils at different stages of acidification. Soil Biol Biochem. doi: 10.1016/00380717(91)90103-Q

Wright SF, Upadhyaya A (1998) A survey of soils for aggregate stability and glomalin, a glycoprotein produced by hyphae of arbuscular mycorrhizal fungi. Plant Soil 198:97-107. doi: 10.1023/A:1004347701584

Wu QS, He XH, Zou YN, et al (2012) Spatial distribution of glomalin-related soil protein and its relationships with root mycorrhization, soil aggregates, carbohydrates, activity of protease and ??-glucosidase in the rhizosphere of Citrus unshiu. Soil Biol Biochem 45:181-183. doi: 10.1016/j.soilbio.2011.10.002

Xu Y gang, Yu W tai, Ma Q, Zhou H (2012) Responses of bacterial and archaeal ammonia oxidisers of an acidic luvisols soil to different nitrogen fertilization rates after 9 years. Biol Fertil Soils 48:827-837. doi: 10.1007/s00374-012-0677-2

Yaalon DH (1997) Soils in the Mediterranean region: What makes them different? Catena. doi: 10.1016/S0341-8162(96)00035-5

Yuan JH, Xu RK (2011) The amelioration effects of low temperature biochar generated from nine crop residues on an acidic Ultisol. Soil Use Manag. doi: 10.1111/j.14752743.2010.00317.x

Zalidis G, Stamatiadis S, Takavakoglou V, et al (2002) Impacts of agricultural practices on soil and water quality in the Mediterranean region and proposed assessment methodology. In: Agriculture, Ecosystems and Environment. pp 137-146

Zechmeister-Boltenstern S, Keiblinger KM, Mooshammer M, et al (2015) The application of ecological stoichiometry to plant-microbial-soil organic matter transformations. Ecol. Monogr.

Zhang B, He H, Ding X, et al (2012) Soil microbial community dynamics over a maize (Zea mays L.) growing season under conventional- and no-tillage practices in a rainfed agroecosystem. Soil Tillage Res 124:153-160. doi: 10.1016/j.still.2012.05.011 
Zhang S, Li Q, Lü Y, et al (2013) Contributions of soil biota to C sequestration varied with aggregate fractions under different tillage systems. Soil Biol Biochem. doi: 10.1016/j.soilbio.2013.03.023

Zhang Z, Liang S, Wang J, et al (2018) Tillage and crop succession effects on soil microbial metabolic activity and carbon utilization in a clay loam soil. Eur J Soil Biol. doi: 10.1016/j.ejsobi.2018.07.006 


\section{APPENDIX}

\section{Articles derived from the thesis:}

Applied Soil Ecology 117-118 (2017) 70-80

Seasonal variation of microbial activity as affected by tillage practice and sugar beet foam amendment under Mediterranean climate

Eduardo Vazquez $^{\mathrm{a}, *}$, Nikola Teutscherova ${ }^{\mathrm{a}, \mathrm{b}, *}$, Javier Almorox ${ }^{\mathrm{a}}$, Mariela Navas ${ }^{\mathrm{a}}$, Rafael Espejo ${ }^{\mathrm{a}}$, Marta Benito ${ }^{\mathrm{a}}$

a Departamento de Producción Agraria, Escuela Técnica Superior de Ingeniería Agronómica, Alimentaria y de Biosistemas, Universidad Politécnica de Madrid, Avda. Puerta de Hierro, E-28040 Madrid, Spain

'Department of Crop Sciences and Agroforestry, Faculty of Tropical AgriSciences, Czech University of Life Sciences Prague, Kamýcka 129, Prague 6-Suchdol, 16500, Czech Republic

\section{A R T I C L E I N F O}

Keywords:

Acid soil

Ca-amendmen

No-tillage

Microbial activity

Soil enzyme activity

Soil moisture

\begin{abstract}
A B S T R A C T
Enhancement of soil organic matter content by no-tillage practice and alleviation of soil acidity by Caamendment application has been recognized as important strategies to combat soil degradation. Based on the limited information about possible interactions between the two commonly used techniques, the aim of this study was (1) to evaluate the long-term effect of no-tillage and Ca-amendment on soil biological activity in a split-plot design established on degraded acid soil in SW Spain, and (2) to analyze the microbial activity fluctuation during a year in a Mediterranean climate with marked seasonality. The studied treatments included fluctuation during a year in a Mediterranean climate with marked seasonality. The studied treatments included
traditional tillage without Ca-amendment application (TT), no-tillage without Ca-amendment application (NT), traditional tillage without Ca-amendment application (TT), no-tillage without Ca-amendment application (NT),
amended traditional tillage (TT-A) and amended no-tillage (NT-A). The used Ca-amendment was the mixture of
sugar beet foam (SF) and red gypsum (RG). A refresh dose of Ca-amendment was applied in October 2014 and sugar beet foam (SF) and red gypsum (RG). A refresh dose of Ca-amendment was applied in October 2014 and
was incorporated into the soil in the TT plots and let on soil surface in NT. Soil samples were collected in January, April, July and October 2015. The Ca-amendment increased the soil pH and the dehydrogenase, $\beta$ glucosidase and acid phosphomonoesterase activity, but decreased microbial biomass carbon (MBC), probably as a result of the neutralizing effect on soil pH. The $\mathrm{pH}$ rise was also linked with the increase of microbial biomass nitrogen (MBN) and could be interpreted as a shift in the microbial population. The long-term effect of NT led to nitroge (MB the water deficient months. The higher availability of organic carbon and the amelioration effect of NT to the water deficient months. The higher availability of organic carbon and the amelioration effect of NT to
extreme conditions in the previous months increased the enzymatic activities, MBC, MBN and basal respiration in the NT plots, especially in July when the soil moisture was minimal and temperatures were high. The combination of both treatments did not show any significant synergistic interaction in any biological parameter. Therefore, we can evaluate the application of Ca-amendment on soil surface in NT fields as feasible alternative to lime application and incorporation from the biological point of view. In addition, the less extreme drought conditions in the NT plots and the consequent higher microbial activity during the summer can be considered as a strategy to increase the biological soil resistance against the drought events in the scenery of climate change. The variable response of the different agricultural practices to climate fluctuation should be included in future The variable response of the different agricultural practices to climate fluctuation should be included in future
research in order to evaluate the response of biogeochemical cycling and organic matter dynamics to predicted future climate change.
\end{abstract}

Abbreviations: ASase, arylsuplhatase; BR, basal respiration; DHase, dehydrogenase; EAs, enzyme activities; Glm, glucosaminidase; Gls, glucosidase; GWC, gravimetric water content; GWC3m, mean gravimetric water content for the three months period prior sampling; RG, red gypsum; MBC, microbial biomass carbon; MBN, microbial biomass nitrogen; NT, no-tillage; PCA, principle components analysis; PHase, phosphatase; POxCp, ermanganate oxidizable carbon; SF, sugar beet foam; SOC, soil organic carbon; SOM, soil organic matter; TT, traditiona tillage

"Corresponding authors at: Departamento de Producción Agraria, Escuela Técnica Superior de Ingeniería Agronómica, Alimentaria y de Biosistemas, Universidad Politécnica de Madrid, Avda. Puerta de Hierro, Madrid, E-28040, Spain.

E-mail addresses: eduardo.vazquez@upm.es (E. Vazquez), nikola.teutscherova@upm.es (N. Teutscherova).

http://dx.doi.org/10.1016/j.apsoil.2017.04.013

Received 19 January 2017; Received in revised form 16 April 2017; Accepted 19 April 2017

0929-1393/ @ 2017 Elsevier B.V. All rights reserved. 


\title{
The interactive effect of no-tillage and liming on gross $\mathrm{N}$ transformation
} rates during the summer fallow in an acid Mediterranean soil

Eduardo Vázquez ${ }^{\mathrm{a}, *}$, Marta Benito ${ }^{\mathrm{a}}$, Mariela Navas ${ }^{\mathrm{a}}$, Rafael Espejo ${ }^{\mathrm{a}}$, Eugenio Díaz-Pinés ${ }^{\mathrm{b}, 1}$, Nikola Teutscherova ${ }^{\mathrm{a}, \mathrm{c}, *}$

a Departamento de Producción Agraria, Escuela Técnica Superior de Ingeniería Agronómica, Alimentaria y de Biosistemas, Universidad Politécnica de Madrid, Avda. Puerta de Hierro, E-28040, Madrid, Spain

b Institute of Meteorology and Climate Research, Atmospheric Environmental Research (IMK-IFU), Karlsruhe Institute of Technology (KIT), Kreuzeckbahnssr. 19, 82467, Garmisch-Partenkirchen, Germany

' Department of Crop Sciences and Agroforestry, Faculty of Tropical AgriSciences, Crech University of Life Sciences Prague, Kamýcka 129, Prague 6-Suchdol, 16500, Czech Republic

\begin{tabular}{l} 
A R T I C L E I N F O \\
\hline Keywords: \\
Soil liming \\
No-tillage \\
Gross N transformations \\
AOA \\
AOB \\
Total soil bacteria \\
Total soil fungi
\end{tabular}

\begin{abstract}
A B S T R A C T
In the Mediterranean rainfed agriculture, a summer fallow is necessary because of the severe drought and high In the Mediterranean rainfed agriculture, a summer fallow is necessary because of the severe drought and high
temperatures. Due to suppressed plant nitrogen $(\mathrm{N})$ uptake during this period, an accumulation of inorganic $\mathrm{N}$ in the soil may occur, which could be lost from the system during the first autumn rains. Both mineralization and nitrification rates can be affected by agricultural practices, such as tillage or liming, influencing the amount of available $\mathrm{N}$ present in the soil during the fallow period. In this study, we investigated the effects of two common agricultural practices, no-tillage (instead of traditional tillage) and liming, on soil gross $\mathrm{N}$ transformations during the summer fallow. Liming increased gross $\mathrm{N}$ mineralization (from 1.21 to $1.78 \mathrm{mg} \mathrm{N} \mathrm{kg}^{-1}$ day $^{-1}$ ) and gross nitrification (from 0.44 to $0.76 \mathrm{mg} \mathrm{N} \mathrm{kg}^{-1}$ day $^{-1}$ ) while traditional tillage increased $\mathrm{N}$ immobilization. Tillage did not affect gross nitrification but the effect of liming on gross $\mathrm{N}$ mineralization was enhanced in no-tillage plots. The total bacteria abundance was enhanced by liming and no-tillage and seemed to be responsible for plots. The total bacteria abundance was enhanced by liming and no-tillage and seemed to be responsible for
gross $\mathrm{N}$ mineralization and immobilization. The gross mineralization, nitrification and microbial immobilization gross $\mathrm{N}$ mineralization and immobilization. The gross mineralization, nitrification and microbial immobilization
decreased during the summer fallow with an overall reduction by $40 \%, 56 \%, 74 \%$ and $54 \%$ in gross $\mathrm{N}$ mineralization, gross nitrification, ammonium immobilization and nitrate immobilization, respectively. The accumulation of ammonium could be interpreted as a consequence of the decoupling between ammonium production and consumption rates. The increase of gross $\mathrm{N}$ mineralization and nitrification caused by liming application could result in augmented risks of $\mathrm{N}$ losses via nitrate leaching and gaseous losses in autumn, especially under no-tillage. However further studies are required to elucidate the nitrate fate of the in Mediterranean agricultural soils under those management practices.
\end{abstract}

\section{Introduction}

Extensive areas under Mediterranean climate are characterized by soils with low productivity and organic carbon (SOC) content. A strongly seasonal precipitation pattern usually results in a severe drought period during the summer, which requires several months of fallow period between two consecutive growing seasons. In absence of living plants in the soil, ammonium $\left(\mathrm{NH}_{4}{ }^{+}\right)$is mainly subject to two microbial processes: nitrification to nitrate $\left(\mathrm{NO}_{3}{ }^{-}\right)$and microbial immobilization. Thus, the $\mathrm{NH}_{4}{ }^{+}$consumption includes both nitrification and $\mathrm{NH}_{4}{ }^{+}$immobilization. The $\mathrm{NH}_{4}{ }^{+}$immobilization during this period can be beneficial from both the environmental and the agronomic point of view as microbial biomass may operate as a temporal storage until the microbial dieback, when nitrogen $(\mathrm{N})$ and other nutrients are released and become available to the plants (Kuzyakov and $\mathrm{Xu}, 2013)$. On the contrary, the accumulation of $\mathrm{NO}_{3}{ }^{-}$during the fallow period may negatively impact the $\mathrm{N}$ balance with possible implications for N losses (Barton et al., 2011, 2008; Sanchez-Martin et al., 2010; Sanz-Cobena et al., 2017). Previous studies have found strong influence of drought and soil temperature in the gross $\mathrm{N}$

-Corresponding authors at: Departamento de Producción Agraria, Escuela Técnica Superior de Ingeniería Agronómica, Alimentaria y de Biosistemas, Universidad Politécnica de Madrid, Avda. Puerta de Hierro, E-28040, Madrid, Spain.

E-mail addresses: eduardo.vazquez@upm.es (E. Vázquez), nikola.teutscherova@upm.es (N. Teutscherova).

${ }^{1}$ Present address: Institute of Soil Research, University of Natural Resources and Life Sciences (BOKU), Peter-Jordan-Strasse 82, 1190, Vienna, Austria

https://doi.org/10.1016/j.still.2019.104297

Received 27 February 2018; Received in revised form 10 July 2018; Accepted 12 June 2019

0167-1987/ (c) 2019 Elsevier B.V. All rights reserved. 


\title{
Effects of no-tillage and liming amendment combination on soil carbon and nitrogen mineralization
}

Eduardo Vazquez $^{\mathrm{a}, *}$, Marta Benito ${ }^{\mathrm{a}}$, Rafael Espejo ${ }^{\mathrm{a}}$, Nikola Teutscherova ${ }^{\mathrm{a}, \mathrm{b}, * * *}$

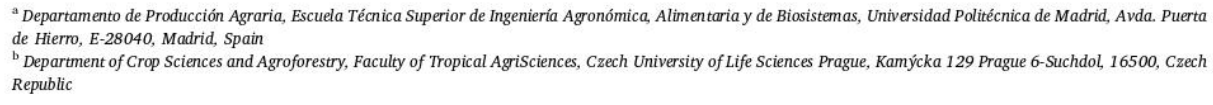

\section{A R T I C L E IN F O}

Handling editor: Yakov Kuzyakov

Keywords:

Carbon mineralization

Nitrogen mineralization

Liming amendment

Structural equation mode

Tillage

\begin{abstract}
A B S T R A C T
Although no-tillage (NT), as opposed to traditional tillage (TT), and lime application are both common practices to increase productivity of degraded soils, our understanding of their interactive effects on $\mathrm{C}$ and $\mathrm{N}$ cycling remains limited. Structural Equation Model (SEM) provides the opportunity to assess the direct and indirect effect of each agronomic practice on soil biogeochemical processes and determine the causal links among studied variables. We investigated the causal relationships among soil chemical and biological properties and C and $\mathrm{N}$ variables. We investigated the causal relationships among soil chemical and biological properties and C and N
mineralization rates as affected by tillage practices (NT versus TT) and liming amendment (sugar foam plus red mineralization rates as affected by tillage practices (NT versus TT) and liming amendment (sugar foam plus red
gypsum versus no amendment) using SEM. The adoption of NT increased soil C content ( 38.3 and $33.7 \mathrm{~g} \mathrm{C} \mathrm{kg}^{-1}$ gypsum versus no amendment) using SEM. The adoption of NT increased soil C content ( 38.3 and $33.7 \mathrm{~g} \mathrm{C} \mathrm{kg}^{-1}$
in NT and TT, respectively), microbial activity and C mineralization in the topsoil, while amendment increased soil pH from 4.25 to $5.49 \mathrm{pH}$ units and accelerated the $\mathrm{N}$ cycling. The SEM revealed that $\mathrm{C}$ mineralization was only affected by tillage practices while net $\mathrm{N}$ mineralization (NNM) was increased by NT adoption and liming amendment. The absence of relevant effects of amendment on $\mathrm{C}$ mineralization indicated that there is no $\mathrm{C}$ depletion risk. However, these results suggest a possible decoupling between the $\mathrm{C}$ and $\mathrm{N}$ mineralization processes with potential implications for $\mathrm{N}$ losses. In addition, SEM revealed that the impact of tillage practice on C and $\mathrm{N}$ mineralization was mediated by changes in the microbial biomass, which highlights the importance of the inclusions of microbial parameters in the nutrient cycling studies as affected by agronomic practices. In coninclusions of microbial parameters in the nutrient cycling studies as affected by agronomic practices. In con-
clusion, the combination of NT and liming amendment increased soil C content, and stimulated N cycling, which could enhance $\mathrm{N}$ availability $\mathrm{N}$ for crops or increase $\mathrm{N}$ losses. This study showed the usefulness of SEM in agronomic experiments, which could help in the future to improve agronomic management and enhance sustainable use of agricultural land.
\end{abstract}

\section{Introduction}

The Mediterranean agricultural areas are exposed to soil degradation due to the peculiarity of the climate, the low biomass production and the use of inadequate practices [1]. In such areas, the adoption of conservation agricultural practices such as no-tillage (NT) as an alternative to traditional tillage (TT) has been accepted as a promising mean to improve and restore soil physical and biochemical properties, increase the storage of total organic C (TOC) and enhance the water use efficiency [2-4]. In addition, the combination of NT with liming amendments to raise the soil $\mathrm{pH}$ and increase the cation availability has been proposed to restore degraded acid soils and increase the crop yields in the Mediterranean region [5].

Although NT and liming are common practices when used individually,

Abbreviations: NT, no-tillage; TT, traditional tillage; F:B, fungi-to-bacteria ratio; SEM, Structural Equation Model; $\mathrm{C}_{0}$, the potentially mineralizable C; $k$, the C mineralization rate constant; $C_{0} k$, initial potential mineralization rate; NNM, net nitrogen mineralization; NN, net nitrification; TOC, soil total organic carbon; TN, total nitrogen; SOM, soil organic matter; POM, particulate organic matter; POxC, permanganate oxidizable carbon; MBC, microbial biomass C; MBN, microbial biomass N; Gmean, geometric mean of the assayed enzymes; LMM, Linear Mixed Model; CFI, comparative fit index; RMSEA, root mean square of approximation; SRMR, standardized root mean square residual; AIC, Akaike Information criteria

" Corresponding author.

${ }^{* *}$ Corresponding author. Departamento de Producción Agraria, Escuela Técnica Superior de Ingeniería Agronómica, Alimentaria y de Biosistemas, Universidad Politécnica de Madrid, Avda. Puerta de Hierro, E-28040, Madrid, Spain.

E-mail addresses: eduardo.vazquez@upm.es (E. Vazquez), teutscherova@ftz.czu.cz (N. Teutscherova).

https://doi.org/10.1016/j.ejsobi.2019.103090

Received 17 April 2019; Received in revised form 18 May 2019; Accepted 20 May 2019

1164-5563/ (c) 2019 Elsevier Masson SAS. All rights reserved. 